\title{
Streamlined Energy-Savings Calculations for Heat-Island Reduction Strategies
}

\author{
Final Report
}

\author{
Hashem Akbari and Steven Konopacki \\ Heat Island Group \\ Lawrence Berkeley National Laboratory \\ Berkeley, California 94720
}

March 2003

This work was supported by the U.S. Environmental Protection Agency (EPA) and by the Assistant Secretary for Energy Efficiency and Renewable Energy, Building Technologies, of the U.S. Department of Energy (DOE) under contract No. DE-AC03-76SF00098. 


\section{Acknowledgement}

This work was supported by the U. S. Environmental Protection Agency (EPA) under the Urban Heat Island Pilot Project (UHIPP) through the U. S. Department of Energy under contract DE-AC03-76SF00098. We acknowledge the support and guidance from Edgar Mercado, Eva Wong, and Jeanne Briskin of the EPA. 


\title{
Streamlined Energy-Savings Calculations for Heat-Island Reduction Strategies
}

\author{
H. Akbari and S. Konopacki \\ Heat Island Group \\ Environmental Energy Technologies Division \\ Lawrence Berkeley National Laboratory
}

\begin{abstract}
We have developed summary tables (sorted by heating- and cooling-degree-days) to estimate the potential of Heat-Island Reduction (HIR) strategies (i.e., solar-reflective roofs, shade trees, reflective pavements, and urban vegetation) to reduce cooling-energy use in buildings. The tables provide estimates of savings for both direct effect (reducing heat gain through the building shell) and indirect effect (reducing the ambient air temperature).

In this analysis, we considered three building types that offer the most savings potential: residences, offices, and retail stores. Each building type was characterized in detail by Pre-1980 (old) or $1980^{+}$(new) construction vintage and with natural gas or electricity as heating fuel. We defined prototypical-building characteristics for each building type and simulated the effects of HIR strategies on building cooling and heating energy use and peak power demand using the DOE-2.1E model and weather data for about 240 locations in the U.S. A statistical analysis of previously completed simulations for five cities was used to estimate the indirect savings. Our simulations included the effect of (1) solar-reflective roofing material on building [direct effect], (2) placement of deciduous shade trees near south and west walls of building [direct effect], and (3) ambient cooling achieved by urban reforestation and reflective building surfaces and pavements [indirect effect].

Upon completion of estimating the direct and indirect energy savings for all the selected locations, we integrated the results in tables arranged by heating- and cooling-degree-days. We considered 15 bins for heating-degree-days, and 11 bins for cooling-degree-days. Energy use and savings are presented per $1000 \mathrm{ft}^{2}$ of roof area.

In residences heated with gas and in climates with greater than 1000 cooling-degreedays, the annual electricity savings in Pre-1980 stock ranged from 650 to $1300 \mathrm{kWh} / 1000 \mathrm{ft}^{2}$; for $1980^{+}$stock savings ranged 300 to $600 \mathrm{kWh} / 1000 \mathrm{ft}^{2}$. For residences heated with electricity, the savings ranged from 350 to $1300 \mathrm{kWh} / 1000 \mathrm{ft}^{2}$ for Pre-1980 stock and $190-600 \mathrm{kWh} / 1000 \mathrm{ft}^{2}$ for $1980^{+}$stocks. In climates with less than 1000 cooling-degree-days, the electricity savings were not significantly higher than winter heating penalties. For gas-heated office buildings, simulations indicated electricity savings in the range of $1100-1500 \mathrm{kWh} / 1000 \mathrm{ft}^{2}$ and $360-700$ $\mathrm{kWh} / 1000 \mathrm{ft}^{2}$, for Pre-1980 and $1980^{+}$stocks, respectively. For electrically heated office buildings, simulations indicated electricity savings in the range of $700-1400 \mathrm{kWh} / 1000 \mathrm{ft}^{2}$ and $100-700 \mathrm{kWh} / 1000 \mathrm{ft}^{2}$, for Pre-1980 and $1980^{+}$stocks, respectively. Similarly, for gas-heated retail store buildings, simulations indicated electricity savings in the range of 1300-1700 $\mathrm{kWh} / 1000 \mathrm{ft}^{2}$ and $370-750 \mathrm{kWh} / 1000 \mathrm{ft}^{2}$, for Pre-1980 and $1980^{+}$stocks, respectively. For electrically heated retail store buildings, simulations indicated electricity savings in the range of 1200-1700 $\mathrm{kWh} / 1000 \mathrm{ft}^{2}$ and $250-750 \mathrm{kWh} / 1000 \mathrm{ft}^{2}$, for Pre-1980 and $1980^{+}$stocks, respectively.
\end{abstract}




\section{Executive Summary}

Urban areas tend to have higher air temperatures than their rural surroundings as a result of gradual surface modifications that include replacing the natural vegetation with buildings and roads. The term "Urban Heat Island" describes this phenomenon. The surfaces of buildings and pavements absorb solar radiation and become hot, which in turn warm the surrounding air. Cities that have been "paved over" do not receive the benefit of the natural cooling effect of vegetation. ${ }^{1}$ As the air temperature rises, so does the demand for air-conditioning $(\mathrm{a} / \mathrm{c})$. This leads to higher emissions by power plants, as well as increased smog formation as a result of warmer temperatures. Strategies to reverse the heat-island effect include planting shade trees and other vegetation and incorporating high-albedo ${ }^{2}$ roofs and pavements into the urban landscape.

In 1997, the U.S. Environmental Protection Agency (EPA) embarked on an initiative to quantify the potential benefits of Heat Island Reduction (HIR) strategies (i.e., shade trees, urban vegetation, reflective roofs, and reflective pavements) to reduce cooling-energy use in cities, improve urban air quality and reduce $\mathrm{CO}_{2}$ emissions from power plants. Under this effort, entitled the "Heat Island Reduction Initiative," EPA has been engaged in research and implementation activities that include a comprehensive technical effort called the Urban Heat Island Pilot Project (UHIPP).

The objective of the UHIPP was to investigate the effect of HIR strategies to reduce cooling-energy use in buildings and to reduce ambient air temperature. Cooling ambient air temperature has the additional benefit of reducing the rate of urban smog formation, hence, improving urban air quality.

Five cities were selected for the UHIPP: Baton Rouge, LA; Chicago, IL; Houston, TX; Sacramento, CA; and Salt Lake City, UT. Since the inception of the project, Lawrence Berkeley National Laboratory (LBNL) has conducted detailed studies to investigate the effect of HIR strategies on heating- and cooling-energy use of the five selected pilot cities. In addition, LBNL has collected urban surface characteristic data and conducted preliminary meteorology and urban smog simulations for the pilot cities.

In two earlier reports, we summarized our efforts to calculate the annual energy savings, peak power avoidance and annual $\mathrm{CO}_{2}$ reduction of HIR strategies in the five UHIPP metropolitan areas (Konopacki and Akbari, 2000 and 2002). In this report, we extend those earlier analyses to all other cities in the U.S.

In this study, we followed the same methodology used for analysis of the five UHIPP cities. The methodology consists of (1) defining prototypical buildings; for 240 U.S. climates (2) simulating the basecase heating- and cooling-energy use for each prototype; (3) simulating the energy effects of shade trees and reflective roofs for each prototype; (4) estimating the effect of ambient cooling on heating- and cooling-energy use of each prototype; and (5) integrating and tabulating the total energy savings by ranges of heating- and cooling-degree-days.

\footnotetext{
${ }^{1}$ Evaporation of liquid water occurs at the leaf surface and lowers the local air temperature.

${ }^{2}$ When sunlight hits a surface some fraction of its energy is reflected (albedo $=\hat{a}$ ) and the remainder is absorbed $(\alpha=1-\hat{a})$. High-a surfaces become cooler than low-â surfaces and consequently lower the cooling load of a building.
} 


\section{Project Objective}

The objective of this project was to develop a streamlining approach to estimate the effect of Heat Island Reduction (HIR) measures on building cooling- and heating-energy use. The results are presented in tabular formats for easy interpolation. In this analysis, we focused on three major building types that offer most savings potential: ${ }^{1}$ residence, office, and retail store. For each prototype, we calculated the effects of HIR strategies A-D on heating- and cooling-energy use:

A. Use of solar-reflective roofing material on building ['cool roofs', direct effect],

B. Placement of deciduous shade trees near south and west walls of building ['shade trees', direct effect $]$,

C. Urban reforestation with reflective building surfaces and pavements [indirect effect],

D. Combination of strategies A through C [direct and indirect effects].

\section{Methodology}

A five-step methodology was developed to assess the potential impact of HIR measures on buildings and metropolitan-wide energy use.

1. Define detailed prototypical building characteristics for Pre-1980 and $1980^{+}$construction.

2. Simulate annual energy use and peak demand using the DOE-2.1E model.

3. Determine direct energy and demand savings from each HIR strategy.

4. Determine total indirect energy and demand savings from all HIR strategies.

Results

The results of this analysis are summarized in three tables and three figures. Tables 6-8 give the results for residential, office, and retail store buildings. Each table provides estimates of savings arranged by (a) heating-degree-days and (b) cooling-degree-days. The values in these tables are also plotted in Figures 3-5 for residential, office, and retails store buildings, respectively. Each figure is plotted by (a) heating-degree-days, (b) cooling-degree-days, (i) basecase energy and demand use, (ii) direct savings (penalties) from cool roofs, (iii) direct savings (penalties) from shade trees, (iv) the indirect savings from cool surfaces (roofs and pavements) and increased urban vegetation, and (v) the combined direct and indirect savings.

We also calculated the total carbon emissions from heating and cooling the buildings (Tables 6c, 6d, 7c, 7d, 8c, and 8d). To generate these tables we used data provided by DOE's office of Energy Information Administration (EIA, 1997, 2002).

Table EX-1 summarizes these results of all U. S. climates. Figures EX-1 through EX-5 depict sample results for residential buildings. These figures (and the associated tables) can be used to read the estimated savings for each HIR measure. The report concludes the analysis by

\footnotetext{
${ }^{1}$ These building types were selected based on an earlier detailed study of the direct energy savings potential of highly-reflective roofs in eleven U.S. metropolitan areas, in which they were determined to account for over $90 \%$ of the national energy savings (Konopacki et al. 1997).
} 
providing an example for estimating citywide savings by implementing measures to install cool roofs and programs to plant shade trees. 


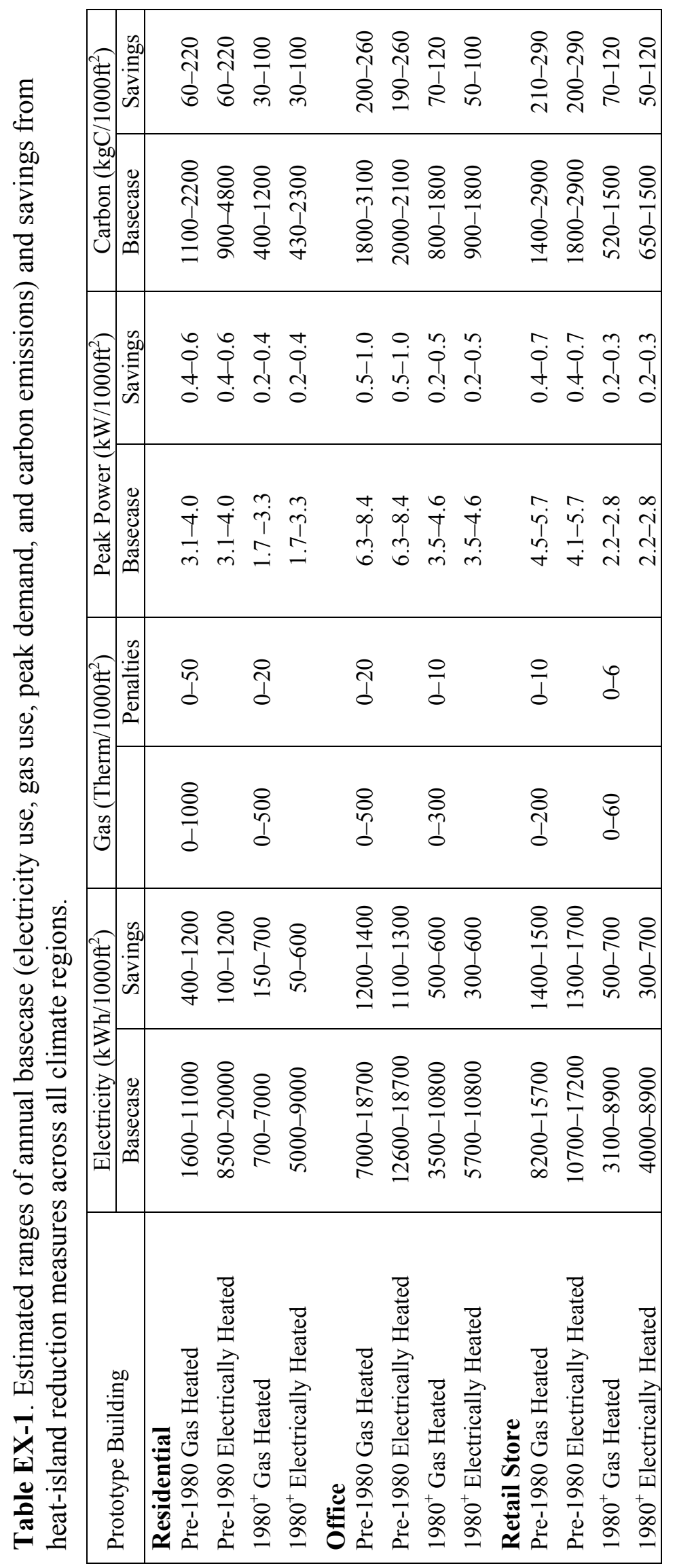



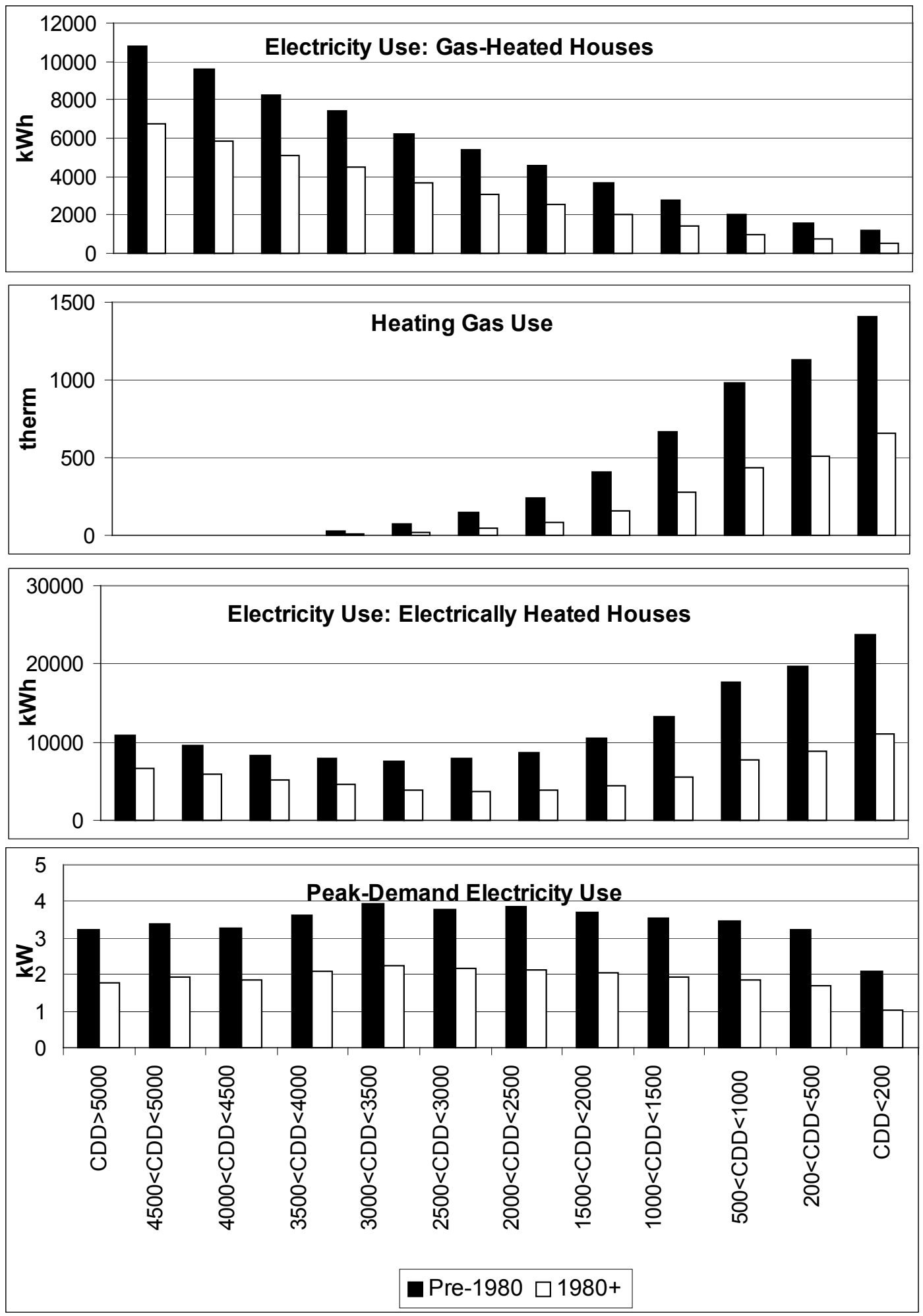

Figure EX-1. Residential Buildings. Basecase Energy Use as a function of cooling-degreedays: Annual basecase cooling-electricity use and heating-gas use for gas-heated houses, combined cooling- and heating-electricity use for electrically heated houses, and peak-electricity demand. All estimates are normalized per $1000 \mathrm{ft}^{2}$ of roof area. 

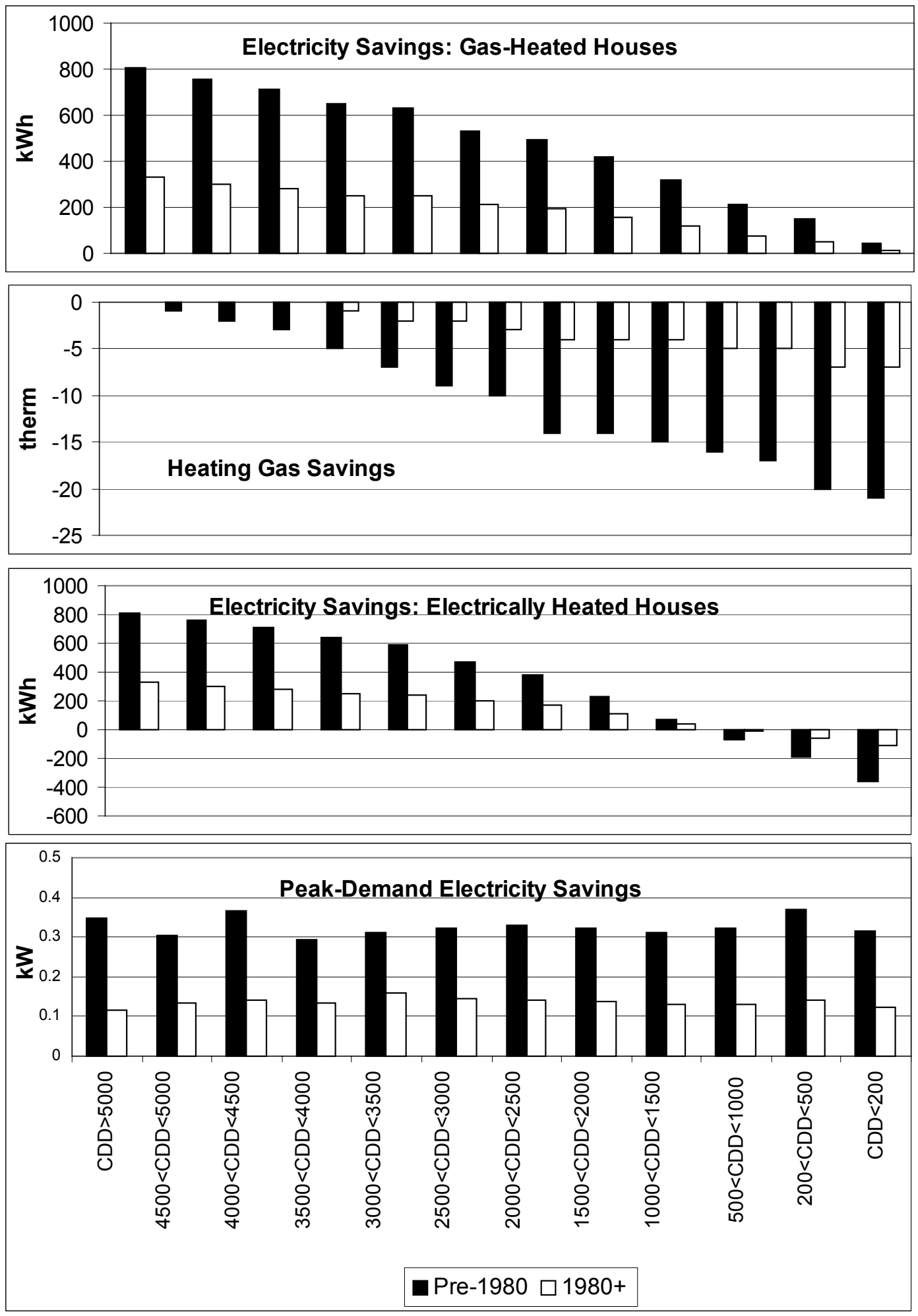

Figure EX-2. Residential Buildings. Savings from Cool Roofs as a function of coolingdegree-days: Annual cooling-electricity savings and heating-gas savings for gas-heated houses, combined heating- and cooling-electricity savings for electrically heated houses, and peakelectricity demand savings. All estimates are normalized per $1000 \mathrm{ft}^{2}$ of roof area. 

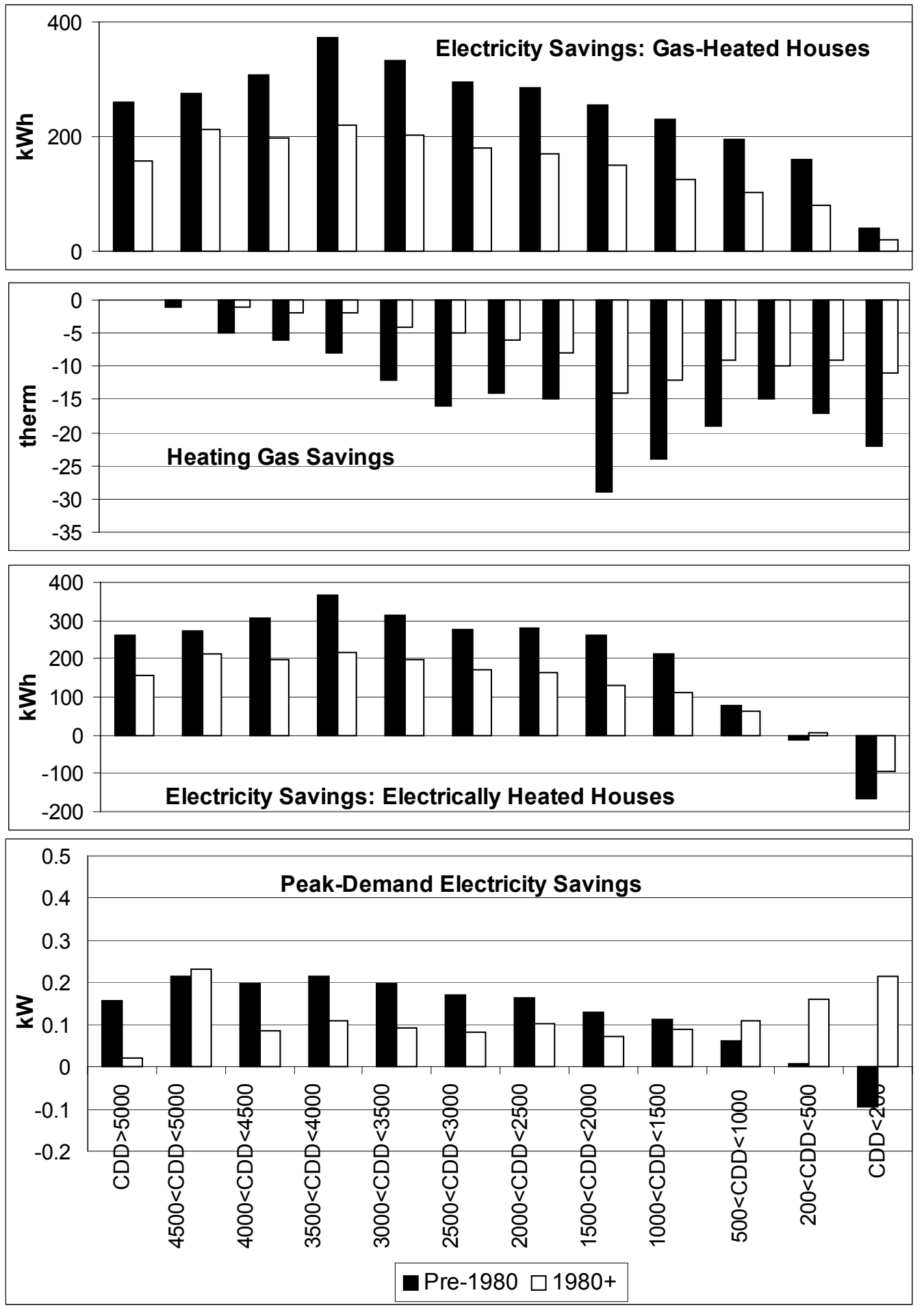

Figure EX-3. Residential Buildings. Savings from Shade Trees as a function of coolingdegree-days: Annual cooling-electricity savings and heating-gas savings for gas-heated houses, combined heating- and cooling-electricity savings for electrically heated houses, and peakelectricity demand savings. All estimates are normalized per $1000 \mathrm{ft}^{2}$ of roof area. 

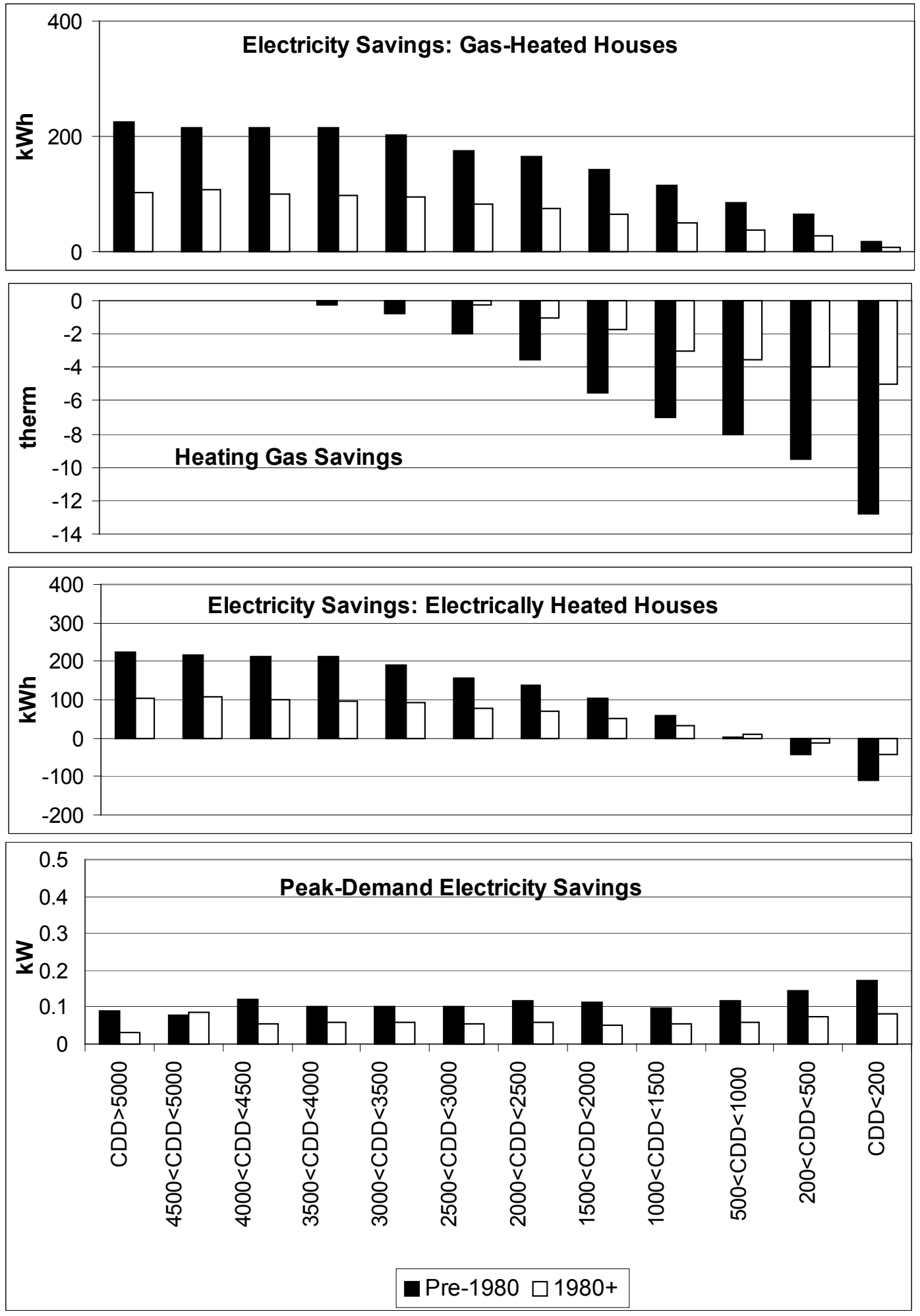

Figure EX-4. Residential Buildings. Indirect Savings as a function of cooling degree-days: Annual cooling-electricity savings and heating-gas savings for gas-heated houses, combined heating- and cooling-electricity savings for electrically heated houses, and peak-electricity demand savings. All estimates are normalized per $1000 \mathrm{ft}^{2}$ of roof area. 

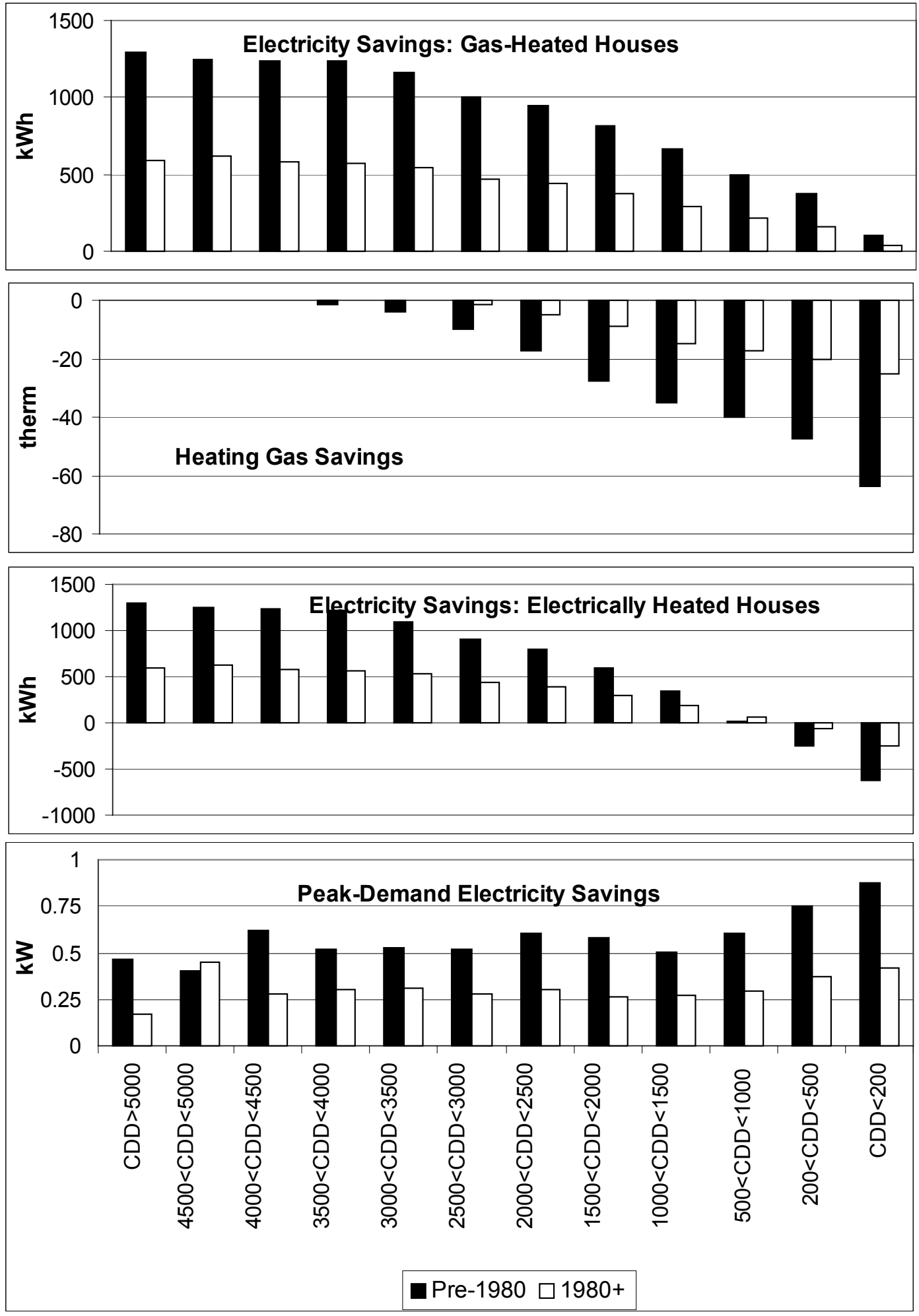

Figure EX-5. Residential Buildings. Combined Direct and Indirect Savings as a function of cooling-degree-days: Annual cooling electricity savings and heating gas savings for gas heated houses, combined heating and cooling electricity savings for electricity-heated houses, and peak electricity demand savings. All estimates are normalized per $1000 \mathrm{ft}^{2}$ of roof area. 


\section{Table of Contents}

Acknowledgement............................................................................................................................. ii

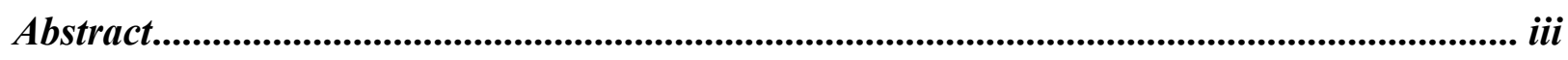

Executive Summary ................................................................................................................. iv

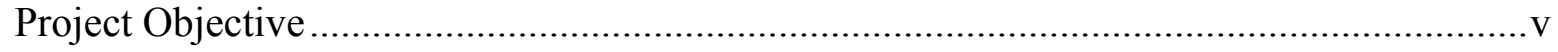

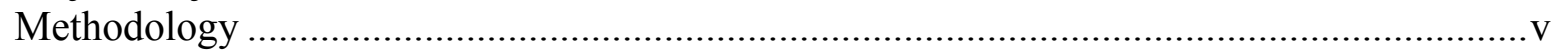

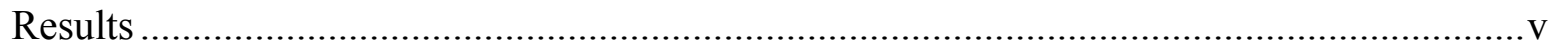

Table of Contents .............................................................................................................................. xiii

List of Tables .................................................................................................................................. xiv

List of Figures..............................................................................................................................

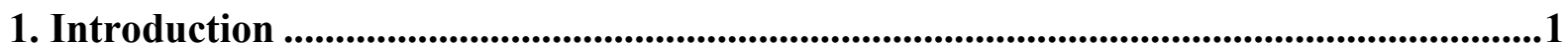

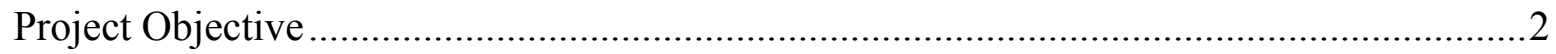

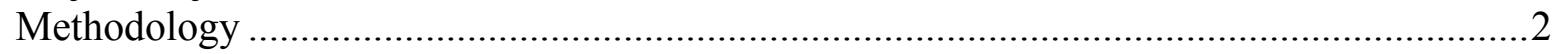

2. Building Descriptions, Reflective Roofs, and Shade Trees ..................................................3

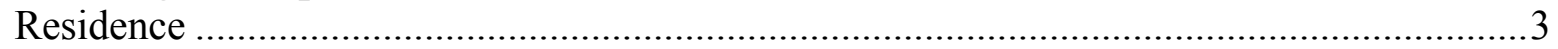

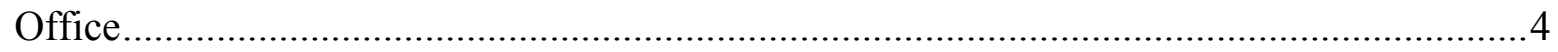

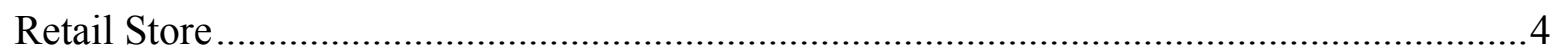

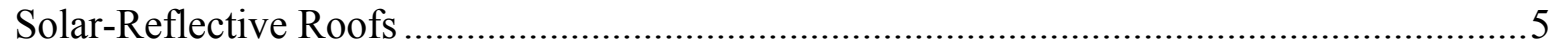

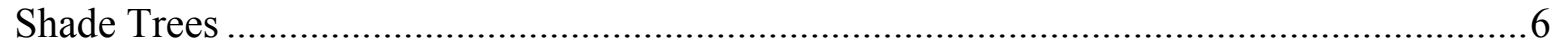

3. Energy Simulations .......................................................................................................................10

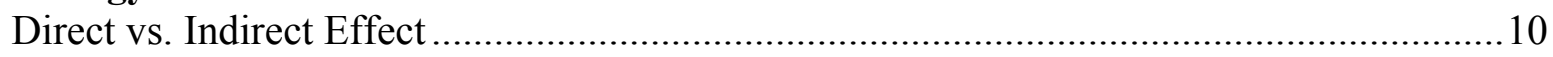

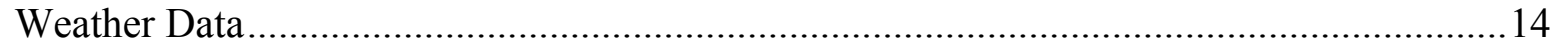

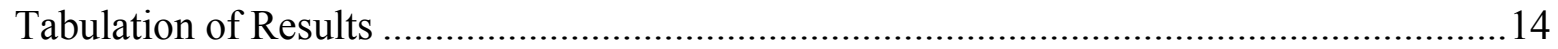

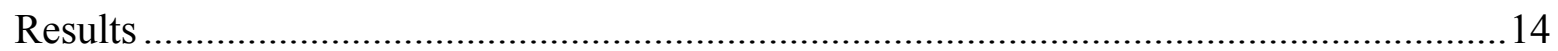

4. Using Tables 6-8 to Estimate the Heat-Island Reduction Potential for a City..............57

Estimating Savings for Individual buildings...................................................................5

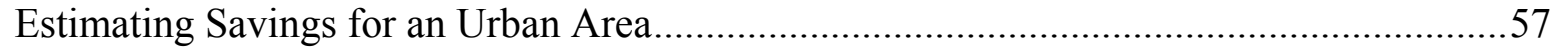

5. Summary and Conclusions ..............................................................................................65

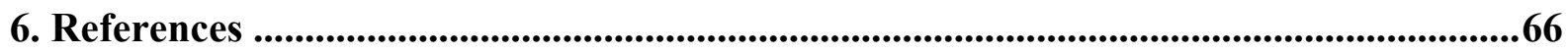




\section{List of Tables}

Table EX-1. Estimated ranges of annual basecase (electricity use, gas use, peak demand, and carbon emissions) and savings from heat-island-reduction measures across all climate regions.vii

Table 1. Prototypical building description for single-family residence......................................

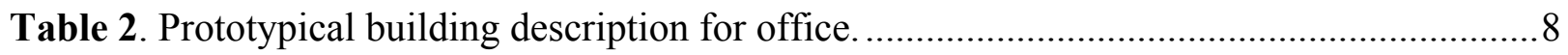

Table 3. Prototypical building description for retail store. .......................................................

Table 4. Summary weather data. The bin ranges for heating- and cooling-degree-days are listed

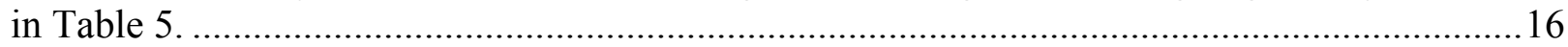

Table 5. Bins of heating- and cooling-degree-days. ...............................................................21

Table 6a. Estimated annual basecase energy use and peak demand, and savings from heat-island reduction measures for residential buildings, ordered by ranges of heating-degree-days..........22

Table 6b. Estimated annual basecase energy use and peak demand and savings from heat-island reduction measures for residential buildings, ordered by ranges of cooling-degree-days. ........25

Table 6c. Estimated annual basecase carbon emissions and savings from heat-island reduction measures for residential buildings, ordered by ranges of heating-degree-days..

Table 6d. Estimated annual basecase carbon emissions and savings from heat-island reduction measures for residential buildings, ordered by ranges of cooling-degree-days.

Table 7a. Estimated annual basecase energy use and peak demand and savings from heat-island reduction measures for office buildings, ordered by ranges of heating-degree-days.

Table 7b. Estimated annual basecase energy use and peak demand and savings from heat-island reduction measures for office buildings, ordered by ranges of cooling-degree-days. .

Table 7c. Estimated annual basecase carbon emissions and savings from heat-island reduction measures for office buildings, ordered by ranges of heating-degree-days.

Table 7d. Estimated annual basecase carbon emissions and savings from heat-island reduction measures for office buildings, ordered by ranges of cooling-degree-days.

Table 8a. Estimated annual basecase energy use and peak demand and savings from heat-island reduction measures for retail store buildings, ordered by ranges of heating-degree-days. ........42

Table 8b. Estimated annual basecase energy use and peak demand and savings from heat-island reduction measures for retail store buildings, ordered by ranges of cooling-degree-days. 45

Table 8c. Estimated annual basecase carbon emissions and savings from heat-island reduction measures for retail store buildings, ordered by ranges of heating-degree-days.

Table 8d. Estimated annual basecase carbon emissions and savings from heat-island reduction measures for retail store buildings, ordered by ranges of cooling-degree-days.

Table 9. Estimated ranges of annual basecase (electricity use, gas use, peak demand, and carbon emissions) and savings from heat-island reduction measures across all climate regions.

Table 10. Estimating citywide savings from the implementation of reflective roofs and shade trees: Example of Houston, TX. 


\section{List of Figures}

Figure EX-1. Residential Buildings. Basecase Energy Use as a function of cooling-degree-days: viii

Figure EX-2. Residential Buildings. Savings from Cool Roofs as a function of cooling-degreedays: ix

Figure EX-3. Residential Buildings. Savings from Shade Trees as a function of cooling-degreedays: $\mathrm{X}$

Figure EX-4. Residential Buildings. Indirect Savings as a function of cooling degree-days: ....xi

Figure EX-5. Residential Buildings. Combined Direct and Indirect Savings as a function of cooling-degree-days: xii

Figure 1. Indirect savings vs. total savings for metropolitan Baton Rouge LA, Chicago IL, Houston TX, Sacramento CA, and Salt Lake City UT.

Figure 2. Percent indirect savings vs. total savings for metropolitan Baton Rouge LA, Chicago IL, Houston TX, Sacramento CA, and Salt Lake City UT.

Figure 3a(i). Residential Buildings. Basecase Energy Use as a function of heating-degree-day: 68 Figure 3b(i). Residential Buildings. Basecase Energy Use as a function of cooling-degree-days:

Figure 3a(ii). Residential Buildings. Effect of Cool Roofs, as a function of heating-degree-days:

Figure 3b(ii): Residential Buildings. Savings from Cool Roofs as a function of cooling-degreedays:

Figure 3a(iii). Residential Buildings. Savings from Shade Trees as a function of heating-degreedays:

Figure 3b(iii). Residential Buildings. Savings from Shade Trees as a function of cooling-degreedays:

Figure 3a(iv). Residential Buildings. Indirect Savings as a function of heating-degree-days: ..74

Figure 3b(iv). Residential Buildings. Indirect Savings as a function of cooling degree days: ...75

Figure $3 \mathrm{a}(\mathrm{v})$. Residential Buildings. Combined Direct and Indirect Savings as a function of

heating-degree-days:

Figure 3b(v). Residential Buildings. Combined Direct and Indirect Savings as a function of cooling-degree-days:

Figure 4a(i). Office Buildings. Basecase Energy Use as a function of heating-degree-days: ....78

Figure 4b(i). Office Buildings. Basecase Energy Use as a function of cooling-degree-days: ...79

Figure 4a(ii). Office Buildings. Effect of Cool Roofs, as a function of heating-degree-days: ...80 
Figure 4b(ii). Office Buildings. Savings from Cool Roofs as a function of cooling-degree-days:

Figure 4a(iii). Office Buildings. Savings from Shade Trees as a function of heating-degree-days:

Figure $4 \mathrm{~b}$ (iii). Office Buildings. Savings from Shade Trees as a function of cooling-degree-days: .83

Figure 4a(iv). Office Buildings. Indirect Savings as a function of heating-degree-days: ..........84

Figure $4 \mathrm{~b}$ (iv). Office Buildings. Indirect Savings as a function of cooling-degree-days: .85

Figure $4 \mathrm{a}(\mathrm{v})$. Office Buildings. Combined Direct and Indirect Savings as a function of heatingdegree-days: .86

Figure $4 \mathrm{~b}(\mathrm{v})$. Office Buildings. Combined Direct and Indirect Savings as a function of coolingdegree-days:

Figure 5a(i). Retail Store Buildings. Basecase Energy Use as a function of heating-degree-day: .88

Figure 5b(i). Retail Store Buildings. Basecase Energy Use as a function of cooling-degree-days:

Figure 5a(ii). Retail Store Buildings. Effect of Cool Roofs, as a function of heating-degree-days:

Figure 5b(ii). Retail Store Buildings. Savings from Cool Roofs as a function of cooling-degreedays:

Figure 5a(iii). Retail Store Buildings. Savings from Shade Trees as a function of heating-degreedays:

Figure $5 b$ (iii). Retail Store Buildings. Savings from Shade Trees as a function of cooling-degreedays:

Figure 5a(iv). Retail Store Buildings. Indirect Savings as a function of heating-degree-days: .94 Figure 5b(iv). Retail Store Buildings. Indirect Savings as a function of cooling-degree-days: .95 Figure 5a(v). Retail Store Buildings. Combined Direct and Indirect Savings as a function of heating-degree-days:

Figure $5 b(v)$. Retail Store Buildings. Combined Direct and Indirect Savings as a function of cooling-degree-days: 


\section{Introduction}

Urban areas tend to have higher air temperatures than their rural surroundings, as a result of gradual surface modifications that include replacing the natural vegetation with buildings and roads. The term "Urban Heat Island" describes this phenomenon. The surfaces of buildings and pavements absorb solar radiation and become hot, which in turn warm the surrounding air. Cities that have been "paved over" do not receive the benefit of the natural cooling effect of vegetation. ${ }^{1}$ As the air temperature rises, so does the demand for air-conditioning $(\mathrm{a} / \mathrm{c})$. This leads to higher emissions by power plants, as well as increased smog formation as a result of warmer temperatures. Strategies to reverse the heat-island effect include planting shade trees and other vegetation and incorporating high-albedo ${ }^{2}$ roofs and pavements into the urban landscape.

In 1997, the U.S. Environmental Protection Agency (EPA) embarked on an initiative to quantify the potential benefits of Heat Island Reduction (HIR) strategies (i.e., shade trees, urban vegetation, reflective roofs, and reflective pavements) to reduce cooling-energy use in cities, improve urban air quality and reduce $\mathrm{CO}_{2}$ emissions from power plants. Under this effort, entitled the "Heat Island Reduction Initiative," EPA has been engaged in research and implementation activities that include a comprehensive technical effort called the Urban Heat Island Pilot Project (UHIPP).

The objective of the UHIPP was to investigate the effect of HIR strategies to reduce cooling-energy use in buildings and to reduce ambient air temperature. Cooling ambient air temperature has the additional benefit of reducing the rate of urban smog formation, hence, improving urban air quality.

Five cities were selected for the UHIPP: Baton Rouge, LA; Chicago, IL; Houston, TX; Sacramento, CA; and Salt Lake City, UT. Since the inception of the project, Lawrence Berkeley National Laboratory (LBNL) has conducted detailed studies to investigate the effect of HIR strategies on heating- and cooling-energy use of the five selected pilot cities. In addition, LBNL has collected urban surface characteristic data and conducted preliminary meteorology and urban smog simulations for the pilot cities.

In two earlier reports, we summarized our efforts to calculate the annual energy savings, peak power avoidance and annual $\mathrm{CO}_{2}$ reduction of HIR strategies in the five UHIPP metropolitan areas (Konopacki and Akbari, 2000 and 2002). In this report, we extend those earlier analyses to all other cities in the U.S.

In this study, we followed the same methodology used for analysis of the five UHIPP cities. The methodology consists of (1) defining prototypical buildings; for 240 U.S. climates (2) simulating the basecase heating- and cooling-energy use for each prototype; (3) simulating the energy effects of shade trees and reflective roofs for each prototype; (4) estimating the effect of ambient cooling on heating- and cooling-energy use of each prototype; and (5) integrating and tabulating the total energy savings by ranges of heating- and cooling-degree-days.

\footnotetext{
${ }^{1}$ Evaporation of liquid water occurs at the leaf surface and lowers the local air temperature.

${ }^{2}$ When sunlight hits a surface some fraction of its energy is reflected (albedo $=\hat{a}$ ) and the remainder is absorbed $(\alpha=1-\hat{a})$. High-a surfaces become cooler than low-â surfaces and consequently lower the cooling load of a building.
} 


\section{Project Objective}

The objective of this project was to develop a streamlining approach to estimate the effect of Heat-Island Reduction (HIR) measures on building cooling- and heating-energy use. The results are presented in tabular formats for easy interpolation. In this analysis, we focused on three major building types that offer most savings potential ${ }^{1}$ : residence, office, and retail store. For each prototype, we calculated the effects of HIR strategies A-D on heating- and cooling-energy use:

A. Use of solar-reflective roofing material on building ['cool roofs', direct effect],

B. Placement of deciduous shade trees near south and west walls of building ['shade trees', direct effect],

C. Urban reforestation with reflective building surfaces and pavements [indirect effect],

D. Combination of strategies A through $\mathrm{C}$ [direct and indirect effects].

\section{Methodology}

A five-step methodology was developed to assess the potential effects of HIR measures on buildings and metropolitan-wide energy use.

1. Define detailed prototypical building characteristics for Pre-1980 and 1980 $^{+}$ construction. Prototypical building data were identified and used to define construction, internal load, and cooling- and heating-equipment characteristics for residential, office and retail buildings. The prototypes were developed for both Pre-1980 and $1980^{+}$construction vintages and with both gas and electricity as heating fuels. The use of existing and reflective roofs and the placement of deciduous shade trees near the south and west sides of the building were considered. These data then defined the characteristics of the Building Description Language used by the DOE-2.1E energy simulation computer program (Winklemann et al., 1993; BESG, 1990).

2. Simulate annual energy use and peak demand using the DOE-2.1E model. The DOE-2 building-energy model was used to simulate the direct effects of reflective roofs and shade trees and on cooling- and heating-energy use for the selected prototypical buildings. The DOE- 2 model simulates energy use of a building for 8760 hours of a year, using typical hourly weather data. Simulations were performed for basecase and the modified cases (as defined by HIR strategies).

3. Determine direct energy and demand savings from each HIR strategy. Simulated annual cooling- and heating-energy savings and avoided peak power were calculated by comparing the basecase energy use and demand to those of the HIR strategies. All results were normalized per $1000 \mathrm{ft}^{2}$ of roof area.

4. Determine total indirect energy and demand savings from all HIR strategies. To estimate the indirect effect, we developed simple algorithms to estimate indirect savings from detailed analysis previously completed for Baton Rouge LA, Chicago IL, Houston TX, Sacramento CA, and Salt Lake City UT. The algorithms are based on the regression of the estimated indirect savings vs. (1) cooling-electricity savings for gas-heated buildings, (2) gas heating-energy

\footnotetext{
${ }^{1}$ These building types were selected based on an earlier detailed study of the direct energy savings potential of highly-reflective roofs in eleven U.S. metropolitan areas, in which they were determined to account for over $90 \%$ of the national energy savings (Konopacki et al. 1997).
} 
penalties for gas-heated buildings, (3) cooling- and heating-electricity savings for electrically heated buildings, and (4) peak electricity demand, for the five pilot cities.

\section{Group energy-saving potentials in tables ordered by annual Cooling- and Heating} Degree-Days. After estimating the direct and indirect energy savings, and hence, total energy saving potentials, we averaged the saving estimates for climate zones in a range of heating- and cooling-degree-days (HDD and CDD). The final results were then tabulated by ranges of CDD and HDD.

\section{Building Descriptions, Reflective Roofs, and Shade Trees}

Three major building prototypes were selected for investigation: (1) residence (2) office (3) retail store. Konopacki et al. (1997), in a detailed study to quantify the effects of reflective roofs in 11 Metropolitan Statistical Areas (MSAs), showed that these three building types accounted for $93 \%$ of the residential and commercial air-conditioned roof area. The buildings were characterized for old (those built prior to 1980) and new (built 1980 or later) construction vintages. Two heating systems were available for each prototype, natural gas furnace and airsource electric heat pump. The prototype characteristics were written into Building Description Language (BDL) for DOE-2 modeling.

\section{Residence}

The residence was modeled as a single-story single-family detached structure. Changing the reflectance of the roof, primarily affects the heat transfer through the roof structure. Therefore, to minimize the variations in the number of prototypes for simulations, we focused on prototypical simulations of the upper floor capturing the effects of changes in roof reflectance and the addition of shade trees in the building as a whole. The average roof area selected for these prototypical simulations was $1600 \mathrm{ft}^{2}$. We presented the simulated data by normalizing the energy use savings per $1000 \mathrm{ft}^{2}$ of roof area. Then, in the example provided for calculating the savings for a metropolitan area, we accounted for the number of stories of the building stock.

The roof was constructed with asphalt shingles on a $20^{\circ}$ sloped plywood deck, over a naturally ventilated and unconditioned attic, above a studded ceiling frame with fiberglass insulation (varying by vintage), and with a sheet of drywall beneath. The fractional-leakage-area of the attic and living quarters was dependent on vintage. Variable air infiltration was modeled by the Sherman-Grimsrud algorithm (Sherman 1986). The existing solar reflectance of the roof was 0.2 , typical for a white asphalt shingles, and the albedo of the reflective roof was taken to be 0.5 , typical for aged white roof coatings. The thermal emittance of both roofs was 0.9 .

The residence was cooled and heated by a central air-conditioning system with ducts located in the attic space, a constant volume fan, and without an economizer. Cooling by natural ventilation was available by window operation. The systems were sized based on peak cooling and heating loads as determined by DOE-2, allowing for peak loads to be met. System component efficiencies were selected for each vintage. A Seasonal Energy Efficiency Ratio (SEER) of 8.5 and 10 was assumed for the central air-conditioner of the Pre-1980 and $1980^{+}$ buildings, respectively. Also a Heating Season Performance Factor (HSPF) of 5 and 7 was assumed for the stock of old and new residential central electric heat pumps.

Modified part-load-ratio curves for a typical air-conditioner, heat pump, and gas furnace were used in place of the standard DOE-2 curves, as they have been shown to model low-energy use more accurately (Henderson 1998). Duct loads were simulated with a validated residential 
duct function (Parker et al. 1998) implemented into DOE-2 to better estimate the thermal interactions between the ducts and space. The function was designed for the residential central system type (RESYS) in DOE-2 and for a single air-conditioned living space with an attic and basement, and it greatly improves cooling- and heating-energy use estimates.

Building data for residences are shown in Table 1 and were obtained from several sources. We used existing data to characterize the existing stock of Pre-1980 buildings (Konopacki et al., 1997). Characteristics for $1980^{+}$construction homes were identified from DOE national appliance energy standards (NAECA 1987), California Energy Commission prototypes (CEC 1994), and Energy Star® (USDOE 2001).

\section{Office}

The office was modeled as a non-directional building with four perimeter zones and a core zone, also in two construction vintages, those built prior to 1980, those built 1980 and after. The floor plan was a 70 feet by 70 feet layout with a total conditioned floor area of $4900 \mathrm{ft}^{2}$, and the perimeter zone depth was 15 feet. The building operated from 6am to $7 \mathrm{pm}$ on weekdays only.

The roof was constructed with built-up materials on a flat plywood deck, over an unventilated and unconditioned plenum, above a studded ceiling frame with fiberglass insulation (varying by vintage), and with a sheet of drywall beneath. The existing solar reflectance of the roof was 0.2 , typical for gray or tan built-up, and the albedo of the reflective roof was taken to be 0.6 , typical for aged white roof coatings. The thermal emittance of both roofs was 0.9 .

The building was cooled and heated by five rooftop, constant volume, packaged-singlezone systems, each one servicing a single zone. The systems were sized based on peak cooling and heating loads as determined by DOE-2, which allowed for peak loads to be met. Duct loads were simulated by specifying air leakage and temperature drop. An economizer was also implemented. An EER of 10 was used to model the new office air-conditioner.

Office characteristics were taken from previous research focusing on the impact of reflective roofs in 11 US metropolitan areas (Konopacki et al. 1997), California Energy Commission prototypes (CEC 1994), and Energy Star® (USDOE 2001). These are displayed in Table 2.

\section{Retail Store}

The retail store was modeled as a non-directional building with a single zone, also in two construction vintages, those built prior to 1980, those built 1980 and after. The floor plan was a 90 feet by 90 feet layout with $8100 \mathrm{ft}^{2}$ of total conditioned floor area. The building operated from 8 am to $9 \mathrm{pm}$ on weekdays and from $10 \mathrm{am}$ to $5 \mathrm{pm}$ on weekends and holidays.

The roof was constructed with built-up materials on a flat plywood deck, over an unventilated and unconditioned plenum, above a studded ceiling frame with fiberglass insulation, and with a sheet of drywall beneath. The existing solar reflectance of the roof was 0.2 , typical for gray or tan built-up, and the albedo of the reflective roof was taken to be 0.6 , typical for aged white roof coatings. The thermal emittance of both roofs was 0.9.

The building was cooled and heated by a single rooftop, constant volume packagedsingle-zone system. The system was sized based on peak cooling and heating loads as determined by DOE-2. Duct loads were simulated by specifying air leakage and temperature 
drop. An economizer was also implemented. An EER of 10 was used to model the new retail store air-conditioner.

Retail store characteristics were taken from previous research focusing on the impact of reflective roofs in 11 US metropolitan areas (Konopacki et al. 1997), California Energy Commission prototypes (CEC 1994), and Energy Star ${ }^{\circledR}$ (USDOE 2001). These are displayed in Table 3.

\section{Solar-Reflective Roofs}

A solar-reflective roof is typically light in color and absorbs less sunlight than a conventional dark-colored roof. Less absorbed sunlight means a lower surface temperature, directly reducing heat gain from the roof and air-conditioning demand. Typical albedo values for low- and highalbedo roofs were selected that cover the wide range of commercially available roofing materials (shingles, tiles, membranes and coatings). We also accounted for the effects of weathering and aging. These values were obtained primarily from the Cool Roofing Materials Database (CRMD 2001) developed at LBNL, which contains measured values of roof absorptance across the solar spectrum.

For the sloped-roof ${ }^{1}$ residential sector, available highly reflective materials are scarce. White asphalt shingles are available, but have a relatively low albedo of about 0.25 . Although it can be argued that white coatings can be applied to shingles or tiles to obtain an aged albedo of about 0.5 , this practice is not followed in the field. Some highly reflective white shingles are being developed, but are only in the prototype stage. Some reflective tiles and metal roofing products with greater than $50 \%$ reflectivity are also available. Conversely, highly reflective materials for the low-slope commercial sector are on the market. White acrylic, elastomeric and cementatious coatings, as well as white thermoplastic membranes, can now be applied to built-up roofs to achieve an aged solar reflectance of 0.6.

The values of roof albedo were chosen to be 0.2 and 0.5 for residential roofs and 0.2 and 0.6 for commercial roofs, which represent low- and high-albedo materials. The long-wave thermal emittance of these materials was a uniform 0.9. In DOE-2 the ABSORPTANCE keyword for roof construction was 0.8 (reflectivity of 0.2 ) for the basecase and was changed to 0.5 (0.5 reflectivity) and 0.4 ( 0.6 reflectivity) for residential and commercial reflective roofs, respectively.

Bretz and Akbari (1997) have reported that the albedo of white-coated roof surfaces can degrade up to $20 \%$ over a period of several years as a result of weathering and accumulation of dirt and debris (microbial growth can contribute to degradation in humid climates). By washing the roof, the albedo can be restored to $90-100 \%$ of the initial value. Note that rainfall can cleanse a roof and have the same effect as a thorough washing.

A "generic white" asphalt shingle has a laboratory-tested initial albedo of 0.25 (CRMD 2001). A "generic grey" asphalt shingle has a laboratory-tested initial albedo of 0.22 , and the albedo of a green or brown shingle is about 0.12-0.15 (CRMD 2001). The roofs-built-up asphalt capsheet with light-grey granules — of three commercial buildings in California were

\footnotetext{
${ }^{1}$ A roof with higher than $9.5^{\circ}$ slope is defined as a sloped roof. The roofing industry has widely accepted a slope of 2:12 or more as a definition of sloped roofs. This corresponds to a slope of approximately $9.5^{\circ}(16.7 \%)$.
} 
coated with a white-elastomeric material, where the measured pre-coated albedo ranged from 0.16 to 0.24 , the initial post-coated albedo was 0.6 , the unwashed albedo ranged from 0.47 to 0.56, and the washed albedo was 0.59 (Konopacki and Akbari 1998, Konopacki et. al. 1998).

\section{Shade Trees}

Shade trees block incoming sunlight to the windows and walls of a building and effectively lower cooling demand. Deciduous shade trees shed their leaves in the winter to allow sunlight to warm the building. Mature deciduous shade trees were modeled in DOE-2 with the BUILDING$S H A D E$ keyword as a box-shaped building shade with seasonal transmittance. The summertime transmittance was 0.1 for 1 April through 31 October and wintertime was 0.9 for the remainder of the year (the fraction of light that passes through the tree is the transmittance). The geometry of the modeled tree consisted of a square cross-sectional area of $225 \mathrm{ft}^{2}, 15$ feet by $15 \mathrm{feet}$, a depth of 10 feet, and a canopy height of 15 feet. They were placed outside the south and west walls near the windows (with 2 feet of clearance from the building) in order to maximize the impact on the building-cooling load. The fully-grown trees shade a portion of the roof during low sun hours, but do not cover any of it. The number of shade trees modeled were 4, 8 and 10 for the residence, office, and retail store, respectively. 
Table 1. Prototypical building description for single-family residence.

\begin{tabular}{|c|c|c|}
\hline Single-Family Residence & Pre-1980 & $1980^{+}$ \\
\hline $\begin{array}{l}\text { single-story, non-directional } \\
\text { roof \& floor area }\left(\mathrm{ft}^{2}\right)\end{array}$ & 1,600 & \\
\hline \multicolumn{3}{|l|}{ Zones } \\
\hline \multicolumn{3}{|l|}{ living (conditioned) } \\
\hline \multicolumn{3}{|l|}{ attic (unconditioned) } \\
\hline \multicolumn{3}{|l|}{ basement (unconditioned) } \\
\hline \multicolumn{3}{|l|}{ Roof Construction } \\
\hline \multicolumn{3}{|l|}{$20^{\circ}$ slope } \\
\hline \multicolumn{3}{|l|}{$1 / 4^{\prime \prime}$ asphalt shingle } \\
\hline \multicolumn{3}{|l|}{$3 / 4 "$ plywood deck w/ 2" x 6" rafters } \\
\hline \multicolumn{3}{|l|}{ naturally ventilated attic } \\
\hline \multicolumn{3}{|l|}{ 3/4" plywood deck w/ 2" x $6 "$ rafters $(15 \%)$} \\
\hline fiberglass insulation $(85 \%)$ & $\mathrm{R}-11$ & $\mathrm{R}-30$ \\
\hline \multicolumn{3}{|l|}{$1 / 2 "$ drywall } \\
\hline \multicolumn{3}{|l|}{ Roof Solar Reflectance } \\
\hline pre & 0.2 & \\
\hline post & 0.5 & \\
\hline Roof Thermal Emittance & 0.9 & \\
\hline \multicolumn{3}{|l|}{ Wall Construction } \\
\hline \multicolumn{3}{|l|}{ brick exterior } \\
\hline \multicolumn{3}{|l|}{ wood frame $(15 \%)$} \\
\hline fiberglass insulation ( $85 \%)$ & $\mathrm{R}-5$ & $\mathrm{R}-13$ \\
\hline \multicolumn{3}{|l|}{$1 / 2 "$ drywall interior } \\
\hline \multicolumn{3}{|l|}{ Windows } \\
\hline \multicolumn{3}{|l|}{ clear with operable shades } \\
\hline number of panes & 1 & 2 \\
\hline \multirow{2}{*}{\multicolumn{3}{|c|}{$\begin{array}{l}\text { window to wall ratio } \\
\text { Fractional Leakage Area }\left(\mathbf{i n}^{2} / \mathbf{1 0 0} \mathbf{f t}^{2}\right)\end{array}$}} \\
\hline & & \\
\hline living & 4 & 2 \\
\hline attic & 8 & 4 \\
\hline \multicolumn{3}{|l|}{$\begin{array}{l}\text { Air-conditioning equipment } \\
\text { central a/c, direct expansion, air-cooled }\end{array}$} \\
\hline seasonal energy efficiency ratio (SEER) & 8.5 & 10 \\
\hline coefficient of performance (COP) & 2.5 & 2.9 \\
\hline cooling setpoint $\left({ }^{\circ} \mathrm{F}\right)$ & 78 & \\
\hline \multicolumn{3}{|l|}{ natural ventilation available } \\
\hline \multicolumn{3}{|l|}{ Heating Equipment } \\
\hline \multicolumn{3}{|l|}{ 1) central forced air gas furnace } \\
\hline efficiency (\%) & 70 & 78 \\
\hline heating setpoint $\left({ }^{\circ} \mathrm{F}\right)$ & 70 & \\
\hline $11 \mathrm{pm}-7$ am setback $\left({ }^{\circ} \mathrm{F}\right)$ & 60 & \\
\hline \multicolumn{3}{|l|}{ 2) central electric heat pump } \\
\hline heating season performance factor (HSFP) & 5 & 7 \\
\hline Duct Air Leakage (\%) & 20 & 10 \\
\hline
\end{tabular}


Table 2. Prototypical building description for office.

\begin{tabular}{|c|c|c|}
\hline $\begin{array}{l}\text { Single-Story Office } \\
\text { non-directional } \\
5 \text { zones (conditioned) } \\
\text { roof \& floor area }\left(\mathrm{ft}^{2}\right)\end{array}$ & Pre-1980 & $\mathbf{1 9 8 0}^{+}$ \\
\hline $\begin{array}{l}\text { Roof Construction } \\
\text { built-up roofing } \\
\text { 3/4" plywood decking }\left(0^{\circ} \text { slope }\right) \\
\text { plenum (unconditioned) }\end{array}$ & & \\
\hline Roof Solar Reflectance & & \\
\hline pre & 0.2 & \\
\hline post & 0.6 & \\
\hline Roof Thermal Emittance & 0.9 & \\
\hline $\begin{array}{l}\text { Ceiling Construction } \\
2 " \mathrm{x} 6 " \text { studded frame (15\%) }\end{array}$ & & \\
\hline $\begin{array}{l}\text { fiberglass insulation ( } 85 \%) \\
1 / 2 \text { " drywall } \\
\text { Wall Construction } \\
\text { brick exterior } \\
\text { wood frame }(15 \%)\end{array}$ & $\mathrm{R}-11$ & $\mathrm{R}-30$ \\
\hline $\begin{array}{l}\text { fiberglass insulation }(85 \%) \\
1 / 2 \text { " drywall }\end{array}$ & R-6 & $\mathrm{R}-13$ \\
\hline $\begin{array}{l}\text { Foundation } \\
\text { slab-on-grade with carpet and pad } \\
\text { Windows } \\
\text { clear with operable shades }\end{array}$ & & \\
\hline $\begin{array}{l}\text { number of panes } \\
\text { window to wall ratio }\end{array}$ & $\begin{array}{c}1 \\
0.5\end{array}$ & 2 \\
\hline $\begin{array}{l}\text { Air-Conditioning Equipment } \\
\text { packaged a/c, direct expansion, air-cooled }\end{array}$ & & \\
\hline $\begin{array}{l}\text { seasonal energy efficiency ration (SEER) } \\
\text { coefficient of performance (COP) }\end{array}$ & $\begin{array}{c}8 \\
2.3\end{array}$ & $\begin{array}{l}10 \\
2.9\end{array}$ \\
\hline $\begin{array}{l}\text { Heating Equipment } \\
\text { (1) gas furnace }\end{array}$ & & \\
\hline $\begin{array}{l}\text { efficiency (\%) } \\
\text { (2) electric heat pump }\end{array}$ & 70 & 74 \\
\hline heating season performance factor (HSPF) & 5 & 7 \\
\hline $\begin{array}{l}\text { Distribution } \\
\text { constant-volume forced air system }\end{array}$ & & \\
\hline $\begin{array}{l}\text { economizer } \\
\text { duct leakage }(\%) \\
\text { duct temnerature dron }\left({ }^{\circ} \mathrm{F}\right)\end{array}$ & $\begin{array}{c}\text { fixed } \\
20 \\
2\end{array}$ & $\begin{array}{c}\text { temperature } \\
10 \\
1\end{array}$ \\
\hline $\begin{array}{l}\text { duct temperature drop }\left({ }^{\circ} \mathrm{F}\right) \\
\text { Thermostat }\end{array}$ & 2 & 1 \\
\hline $\begin{array}{l}\text { weekday operation }(6 \mathrm{am}-7 \mathrm{pm}) \\
\text { cooling setpoint }\left({ }^{\circ} \mathrm{F}\right) \\
\text { heating setpoint }\left({ }^{\mathrm{O}} \mathrm{F}\right)\end{array}$ & $\begin{array}{l}78 \\
70\end{array}$ & \\
\hline $\begin{array}{l}\text { Interior load } \\
\text { infiltration (air-change/hour) }\end{array}$ & 0.5 & \\
\hline $\begin{array}{l}\text { lighting }\left(\mathrm{W} / \mathrm{ft}^{2}\right) \\
\text { equipment }\left(\mathrm{W} / \mathrm{ft}^{2}\right)\end{array}$ & $\begin{array}{l}1.9 \\
1.7\end{array}$ & $\begin{array}{l}1.4 \\
1.5\end{array}$ \\
\hline Occupants & 25 & \\
\hline
\end{tabular}


Table 3. Prototypical building description for retail store.

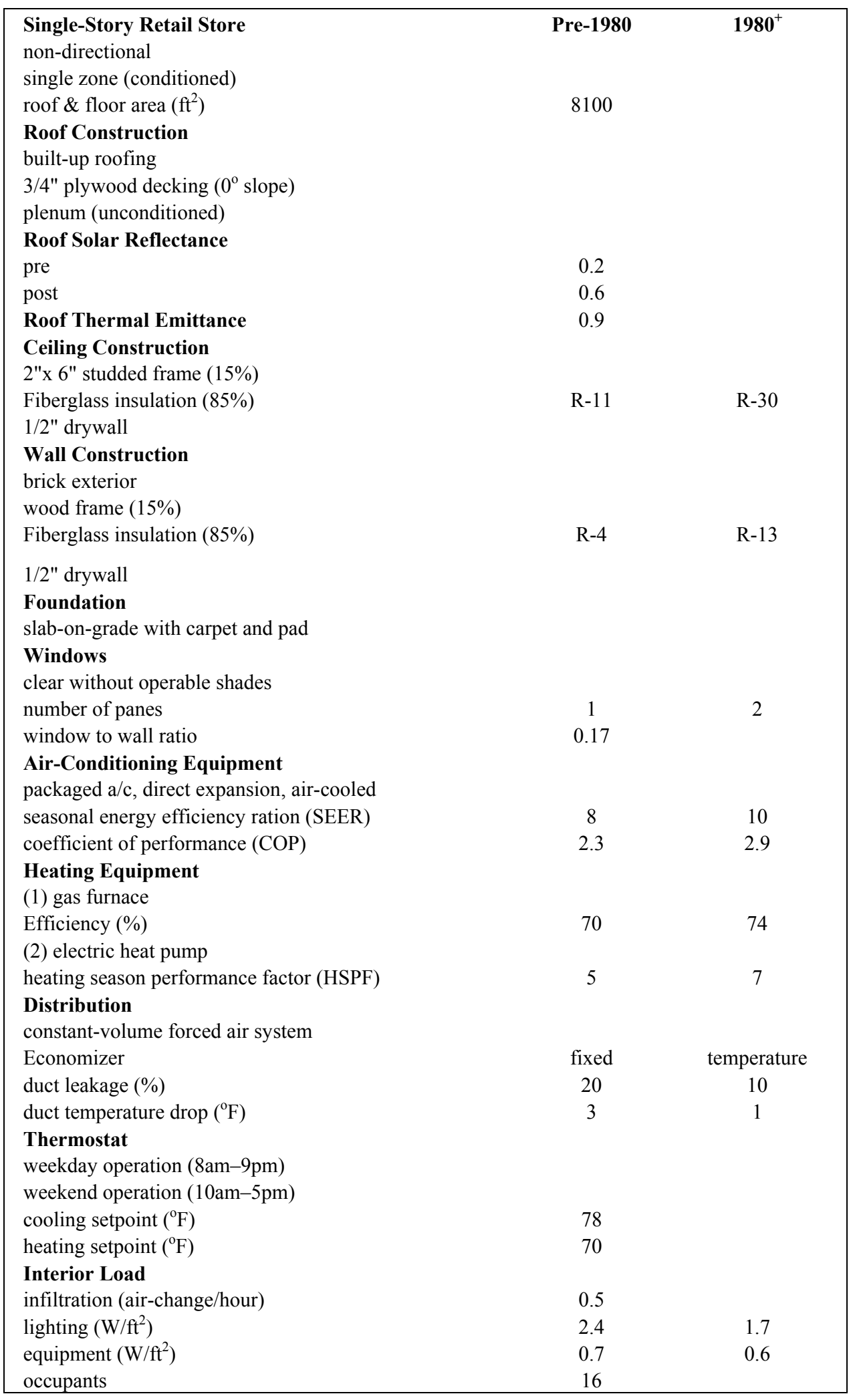




\section{Energy Simulations}

Cooling- and heating-energy use were simulated on an hourly time-step with the DOE-2.1E building energy simulation program (BESG 1990) using TMY2 weather data for residential, office and retail store building prototypes (Pre-1980 and $1980^{+}$construction, natural gas furnace and electric heat pump) and for each Heat-Island Reduction (HIR) strategy (solar-reflective roofs, shade trees and indirect effect).

\section{Direct vs. Indirect Effect}

Strategies to cool cities and mitigate urban heat islands include planting shade trees around buildings, planting other urban vegetation in parks and along roadways, and using solarreflective roofs and pavements. Trees shade buildings and reflective roofs reflect solar energy from buildings, directly reducing demand for air-conditioning ( $\mathrm{a} / \mathrm{c})$. Urban vegetation and reflective surfaces (roofs and pavements) alter the surface energy balance of an area through evapotranspiration of vegetation and by reflecting incident solar energy, lowering the ambient temperature, and hence indirectly reducing a/c use.

Direct Energy Savings. The direct energy-savings potentials were simulated using DOE-2. To calculate the direct energy savings, we perform three sets of simulations for each location (climate). The first set of simulations was performed to establish a basecase energy use condition (heating- and cooling-energy use, and peak electricity cooling demand). The basecase scenario included no external shade and a roof albedo of 0.2 for both the residential and commercial buildings. The second set of simulations (high-albedo roof) was performed to calculate the heating- and cooling-energy use, and peak electricity cooling demand for buildings when they have reflective roofs. For the residence, office and retail store, we assumed a roof solar reflectance of $0.50,0.60$, and 0.60 , respectively. The third set of simulations (shade trees) was performed to calculate the heating- and cooling-energy use, and peak electricity cooling demand for building when trees shade them. For the residence, office and retail store, we assumed 4, 8 and 10 shade trees, respectively. The difference between the basecase and highalbedo roof provided an estimate of energy savings and peak demand reduction by reflective roofs. The difference between the basecase and shade trees provided an estimate of energy savings and peak demand reduction by shade trees.

Indirect Energy Savings. In our previous work, we have used a detailed methodology to calculate the indirect energy and peak-demand saving potentials for the pilot cities investigated. We applied the detailed methodology to calculate the effect for the five selected pilot cities of Baton Rouge LA, Chicago IL, Houston TX, Sacramento CA, and Salt Lake City UT (Konopacki and Akbari 2000, 2002). The calculations for estimating indirect energy effects were carried out in a two-step process. First, a modified TMY2 weather tape was created to represent the effects of HIR strategies on ambient air temperature. Second, the prototypes were simulated with the modified weather tape to calculate the impact of ambient cooling on heating- and cooling-energy use.

To quantify the ambient cooling from the indirect effect for each pilot city, a modified urban fabric was first created from the present fabric with increased urban vegetation, the planting of shade trees, and the use of high-albedo roofs and pavements. Second, the effect of the modified urban fabric on climate was simulated using a meteorological simulation model, from which a modified average drybulb air temperature was obtained from several locations within the boundaries of the model over the 48 hour episode (discussed in detail by Taha and Chang, 
1999a). Then, the modified temperature was calculated for each hour of the year using an algorithm developed by Taha (1999b) based on a statistical analysis of temperature change as a function of solar intensity; because $\Delta \mathrm{T}$ is solely a function of solar, $\Delta \mathrm{T}$ is zero during hours without sunlight. Finally $\Delta \mathrm{T}$ was used to modify the standard TMY2 weather data to create modified temperature data for the building energy simulations.

It is important to notice that in all our previous calculations we assumed that all urban surfaces would be modified to the levels discussed above. This provided an upper boundary for estimates of indirect saving potentials. For the streamlining calculations, we continued to use the same global implementation throughout the cities.

Our objective in this study was to develop a simple method to estimate the indirect effects on energy use and peak demand for many locations in the U.S. For this, we used a statistical approach with data from the detailed analyses of five pilot cities. For these five cities (metropolitan areas) we regressed the indirect saving potential against the total energy savings. We normalized the data by several different methods, and we eventually determined that the direct energy-savings potentials normalized by heating- and cooling-degree-days are fairly well correlated with the total energy-savings potentials (see Figure 1). Using the results of these regressions, we estimated the total indirect electricity savings to be about $17 \%$ of total electricity savings, $20 \%$ for gas penalties, and $19 \%$ for peak demand savings.

Figure 2 compares the percentage of the indirect savings (relative to total savings) for the five pilot cities. The indirect electricity savings range from $11 \%$ (Chicago) to $21 \%$ (Salt Lake City); excluding Chicago the range is $15 \%$ to $20 \%$. The typically short cooling season is a factor to account for Chicago's lower percentage of electricity savings. The indirect penalties from gas heating range from $1 \%$ (Chicago) to $25 \%$ (Houston); excluding Chicago the range is $17 \%$ to $25 \%$. This is very interesting, as it underlines our intuitions that in most cold climates the percentage of winter heating penalties is fairly small (the absolute heating penalties may be higher). In cold climates, there is not much sun during the times when heating is required, hence the effect of a reflective roof on heating energy use is small. The indirect contribution to peak demand savings ranges from $9 \%$ (Chicago) to $30 \%$ (Houston). In this case, in addition to Chicago, the percentage of indirect savings for Baton Rouge is also small (10\%). Although we can provide the same reasoning to explain the difference for Chicago, we do not have such a strong justification for the Baton Rouge savings percentages. The indirect savings for the other three cities range from $24 \%$ to $30 \%$.

It should also be noted that these savings estimates are based on the assumption that all heat-island reduction measure have been fully implemented. Although we have not performed any analysis of partial or gradual implementation of the HIR measures, we assume that the savings, once normalized per square foot of roof area, can be linearly scaled. 

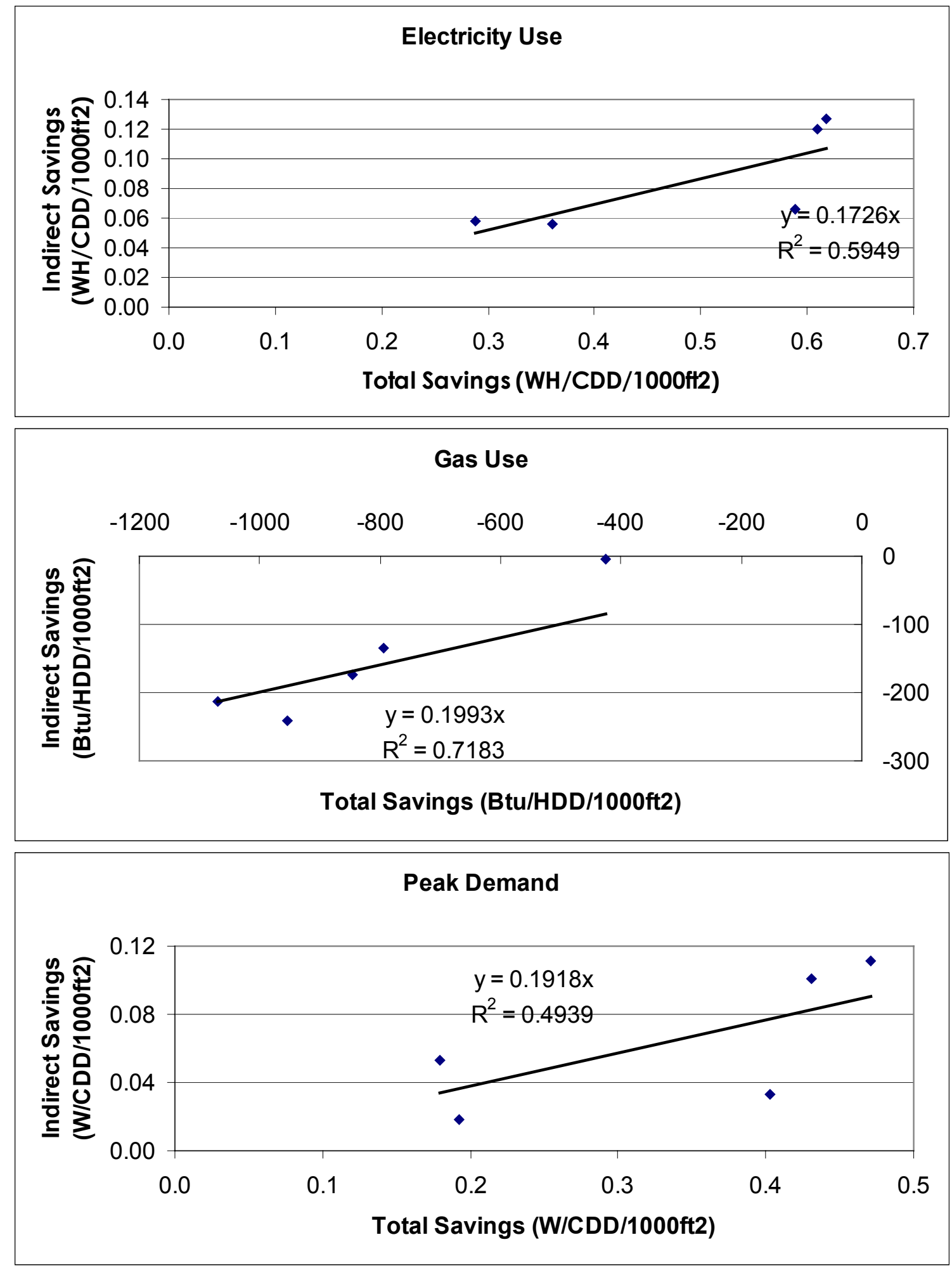

Figure 1. Indirect savings vs. total savings for metropolitan Baton Rouge LA, Chicago IL, Houston TX, Sacramento CA, and Salt Lake City UT. All saving potentials are normalized by cooling- and heating-degree-days, and by total square feet of roof area. 

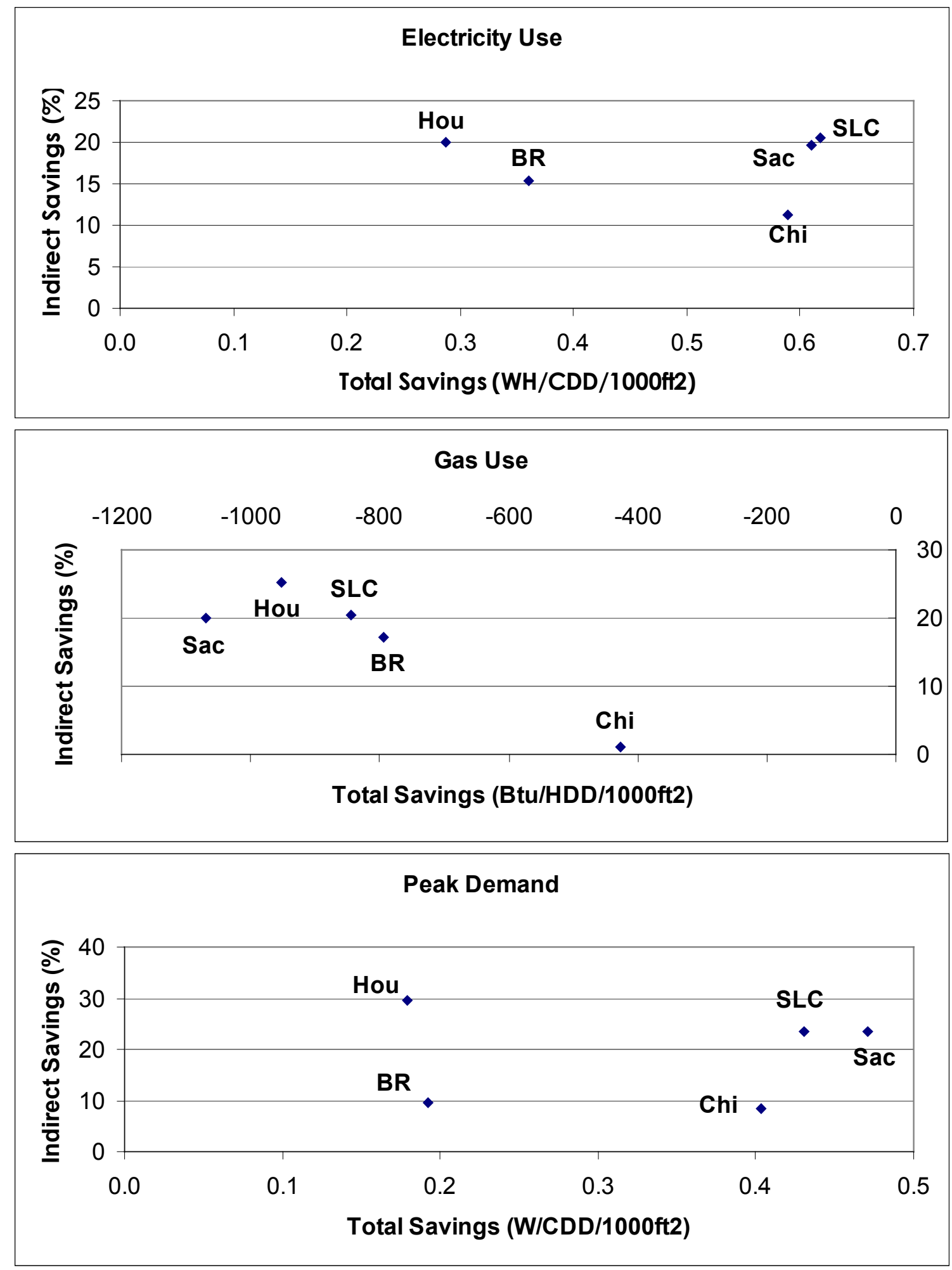

Figure 2. Percent indirect savings vs. total savings for metropolitan Baton Rouge LA, Chicago IL, Houston TX, Sacramento CA, and Salt Lake City UT. All saving potentials are normalized by cooling- and heating-degree-days, and by total square feet of roof area. 


\section{Weather Data}

Local full-year hourly weather data are required as input to the DOE-2 building energy simulation program. Those data used were derived from the 1961-1990 National Solar Radiation Data Base (NREL 1995) and are in the Typical Meteorological Year (TMY2) format. There are 239 weather tapes and they represent conditions from all over the United States. It is important to note that the TMY2 format represents typical rather than extreme climate conditions. Of the 239 tapes, 17 are for Alaska ( 3 of those are unusable) and 6 are for tropical islands (4 in Hawaii, Guam, and San Juan). Some on the west coast are located at coastal airports and have moderate climates, which do not represent inland conditions (these include Los Angeles, Long Beach, San Diego, San Francisco and Seattle). The location, latitude, annual average temperature, heatingdegree-days (base $65^{\circ} \mathrm{F}$ ), and cooling-degree-days (base $65^{\circ} \mathrm{F}$ ) for the simulated climates are shown in Table 4.

The direct energy effects are simulated with the building energy software DOE-2 and standard climate data. The indirect energy impacts are estimated from simple algorithms developed from the detailed analysis previously completed for Baton Rouge LA, Chicago IL, Houston TX, Sacramento CA, and Salt Lake City UT. The algorithms are based on the regression of the estimated indirect savings vs. (1) cooling-electricity savings for gas-heated buildings, (2) gas-heating energy penalties for gas-heated buildings, (3) cooling- and heatingelectricity savings for electrically heated buildings, and (4) peak electricity demand, for the five pilot cities.

\section{Tabulation of Results}

Upon completion of estimating the direct and indirect energy savings for all the locations, we integrated the results in tables arranged by heating- and cooling-degree-days. We considered 15 bins for heating-degree-days, and 11 bins for cooling-degree-days. Table 5 lists the ranges of heating- and cooling-degree-days. Note that the numbers of simulated climates for coolingdegree-days greater than 3000 are small. We would recommend that for these cooling-degreedays bins, the savings be calculated by averaging estimates using both heating- and coolingdegrees tables.

\section{Results}

Tables 6-8 give the results for residential, office, and retail store buildings. Each table provides estimates of savings arranged by (a) heating-degree-days and (b) cooling-degree-days. The values in these tables are also plotted in Figures 3-5 for residential, office, and retails store buildings, respectively. Each figure is plotted by (a) heating-degree-days, (b) cooling-degreedays, (i) basecase energy and demand use, (ii) direct savings (penalties) from cool roofs, (iii) direct savings (penalties) from shade trees, (iv) the indirect savings from cool surfaces (roofs and pavements) and increased urban vegetation, and (v) the combined direct and indirect savings (penalties). It is easier to use Tables 6-8 for estimating energy savings. These figures are used to illustrate the magnitude of the savings and penalties. 
Table 4. Summary weather data. The bin ranges for heating- and cooling-degree-days are listed in Table 5.

\begin{tabular}{|c|c|c|c|c|c|c|}
\hline Location & Latitude & $\begin{array}{l}\text { Annual Average } \\
\text { Temperature }\left({ }^{\circ} \mathrm{F}\right)\end{array}$ & $\begin{array}{c}\text { Cooling- } \\
\text { Degree-Days } \\
\text { (base } 65^{\circ} \mathrm{F} \text { ) }\end{array}$ & $\begin{array}{c}\text { Cooling- } \\
\text { Degree-Days } \\
\text { Bin \# }\end{array}$ & $\begin{array}{c}\text { Heating- } \\
\text { Degree-Days } \\
\text { (base } 65^{\circ} \mathrm{F} \text { ) }\end{array}$ & $\begin{array}{c}\text { Heating- } \\
\text { Degree-Days } \\
\text { Bin \# }\end{array}$ \\
\hline Abilene, TX & 32.43 & 69.7 & 2284 & 7 & 2597 & 6 \\
\hline Akron, OH & 40.92 & 55.2 & 614 & 10 & 6201 & 13 \\
\hline Alamosa, CO & 37.45 & 50.0 & 53 & 12 & 8760 & 15 \\
\hline Albany, NY & 42.75 & 53.4 & 543 & 10 & 7079 & 14 \\
\hline Albuquerque, NM & 35.05 & 62.7 & 1211 & 9 & 4361 & 9 \\
\hline Allentown, PA & 40.65 & 56.5 & 722 & 10 & 5858 & 12 \\
\hline Alpena, MI & 45.07 & 49.5 & 214 & 11 & 8458 & 15 \\
\hline Amarillo, TX & 35.23 & 62.6 & 1294 & 9 & 4655 & 10 \\
\hline Anchorage, AK & 61.17 & 44.4 & 2 & 12 & 10386 & 15 \\
\hline Annette, AK & 55.03 & 48.5 & 3 & 12 & 7215 & 14 \\
\hline Arcata, CA & 40.98 & 54.5 & 4 & 12 & 5196 & 11 \\
\hline Asheville, NC & 35.43 & 60.0 & 748 & 10 & 4512 & 10 \\
\hline Astoria, OR & 46.15 & 54.2 & 14 & 12 & 5291 & 11 \\
\hline Athens, GA & 33.95 & 66.8 & 1640 & 8 & 2850 & 6 \\
\hline Atlanta, GA & 33.65 & 65.7 & 1611 & 8 & 3090 & 7 \\
\hline Atlantic City, NJ & 39.45 & 59.1 & 907 & 10 & 5264 & 11 \\
\hline Augusta, GA & 33.37 & 68.0 & 1778 & 8 & 2887 & 6 \\
\hline Austin, TX & 30.3 & 73.1 & 2965 & 6 & 1630 & 4 \\
\hline Bakersfield, CA & 35.42 & 70.9 & 2367 & 7 & 2100 & 5 \\
\hline Baltimore, MD & 39.18 & 60.5 & 1133 & 9 & 4912 & 10 \\
\hline Baton Rouge, LA & 30.53 & 71.9 & 2444 & 7 & 1653 & 4 \\
\hline Bethel, AK & 60.78 & 38.1 & 2 & 12 & 13094 & 15 \\
\hline Big Delta, AK & 64 & 40.8 & 14 & 12 & 13399 & 15 \\
\hline Billings, MT & 45.8 & 53.6 & 618 & 10 & 7083 & 14 \\
\hline Binghamton, NY & 42.22 & 50.0 & 318 & 11 & 7535 & 14 \\
\hline Birmingham, AL & 33.57 & 67.4 & 1671 & 8 & 2825 & 6 \\
\hline Bismarck, ND & 46.77 & 51.3 & 408 & 11 & 8666 & 15 \\
\hline Boise, ID & 43.57 & 57.5 & 692 & 10 & 6000 & 12 \\
\hline Boston, MA & 42.37 & 54.9 & 646 & 10 & 5841 & 12 \\
\hline Boulder, CO & 40.02 & 57.6 & 623 & 10 & 6007 & 13 \\
\hline Bradford, PA & 41.8 & 48.9 & 143 & 12 & 8245 & 15 \\
\hline Bridgeport, CT & 41.17 & 56.3 & 798 & 10 & 5664 & 12 \\
\hline Bristol, TN & 36.48 & 60.8 & 929 & 10 & 4346 & 9 \\
\hline Brownsville, TX & 25.9 & 77.2 & 3563 & 4 & 659 & 2 \\
\hline Buffalo, NY & 42.93 & 53.3 & 511 & 10 & 6719 & 13 \\
\hline Burlington, VT & 44.47 & 50.7 & 407 & 11 & 7892 & 14 \\
\hline Burns, OR & 43.58 & 52.6 & 285 & 11 & 7072 & 14 \\
\hline Cape Hatteras, NC & 35.27 & 65.5 & 1474 & 9 & 2640 & 6 \\
\hline Caribou, ME & 46.87 & 45.1 & 114 & 12 & 9518 & 15 \\
\hline Casper, WY & 42.92 & 52.6 & 328 & 11 & 7705 & 14 \\
\hline Cedar City, UT & 37.7 & 58.3 & 651 & 10 & 6051 & 13 \\
\hline Charleston, SC & 32.9 & 69.7 & 2010 & 7 & 2209 & 5 \\
\hline Charleston, WV & 38.37 & 60.1 & 903 & 10 & 4632 & 10 \\
\hline Charlotte, NC & 35.22 & 65.1 & 1513 & 8 & 3416 & 7 \\
\hline Chattanooga, TN & 35.03 & 65.1 & 1585 & 8 & 3535 & 8 \\
\hline Cheyenne, WY & 41.15 & 52.6 & 258 & 11 & 7317 & 14 \\
\hline Chicago, IL & 41.78 & 55.4 & 749 & 10 & 6447 & 13 \\
\hline
\end{tabular}




\begin{tabular}{|c|c|c|c|c|c|c|}
\hline Location & Latitude & $\begin{array}{l}\text { Annual Average } \\
\text { Temperature }\left({ }^{\circ} \mathrm{F}\right)\end{array}$ & $\begin{array}{c}\text { Cooling- } \\
\text { Degree-Days } \\
\text { (base } 65^{\circ} \mathrm{F} \text { ) }\end{array}$ & $\begin{array}{c}\text { Cooling- } \\
\text { Degree-Days } \\
\text { Bin \# }\end{array}$ & $\begin{array}{c}\text { Heating- } \\
\text { Degree-Days } \\
\text { (base } 65^{\circ} \mathrm{F} \text { ) }\end{array}$ & $\begin{array}{c}\text { Heating- } \\
\text { Degree-Days } \\
\text { Bin \# }\end{array}$ \\
\hline Cleveland, $\mathrm{OH}$ & 41.4 & 55.8 & 617 & 10 & 6108 & 13 \\
\hline Cold Bay, AK & 55.2 & 42.2 & 0 & 12 & 9550 & 15 \\
\hline Colorado Springs, $\mathrm{CO}$ & 38.82 & 55.4 & 409 & 11 & 6517 & 13 \\
\hline Columbia, MO & 38.82 & 60.2 & 1228 & 8 & 5129 & 6 \\
\hline Columbia, SC & 33.95 & 68.8 & 1898 & 9 & 2765 & 11 \\
\hline Columbus, GA & 32.52 & 69.2 & 2118 & 7 & 2312 & 5 \\
\hline Columbus, $\mathrm{OH}$ & 40 & 57.7 & 779 & 10 & 5551 & 12 \\
\hline Concord, NH & 43.2 & 52.4 & 402 & 11 & 7665 & 14 \\
\hline Corpus Christi, TX & 27.77 & 76.2 & 3267 & 5 & 884 & 2 \\
\hline Covington, KY & 39.07 & 59.3 & 1007 & 9 & 5184 & 11 \\
\hline Cut Bank, MT & 48.6 & 49.0 & 67 & 12 & 8660 & 15 \\
\hline Daggett, CA & 34.87 & 74.3 & 2983 & 6 & 1740 & 4 \\
\hline Dayton, $\mathrm{OH}$ & 39.9 & 56.5 & 715 & 10 & 5927 & 12 \\
\hline Daytona Beach, FL & 29.18 & 74.8 & 2735 & 6 & 871 & 2 \\
\hline Des Moines, IA & 41.53 & 56.1 & 908 & 10 & 6503 & 13 \\
\hline Detroit, MI & 42.42 & 54.4 & 567 & 10 & 6726 & 13 \\
\hline Dodge City, KS & 37.77 & 61.1 & 1371 & 9 & 5353 & 11 \\
\hline Duluth, MN & 46.83 & 44.3 & 140 & 12 & 10186 & 15 \\
\hline Eagle, CO & 39.65 & 50.7 & 71 & 12 & 8355 & 15 \\
\hline Eau Claire, WI & 44.87 & 50.1 & 513 & 10 & 8484 & 15 \\
\hline El Paso, TX & 31.8 & 70.8 & 2046 & 7 & 2597 & 6 \\
\hline Elkins, WV & 38.88 & 54.8 & 345 & 11 & 6289 & 13 \\
\hline Elko, NV & 40.83 & 54.3 & 289 & 11 & 7234 & 14 \\
\hline Ely, NV & 39.28 & 51.6 & 145 & 12 & 8045 & 15 \\
\hline Erie, PA & 42.08 & 52.9 & 454 & 11 & 6757 & 13 \\
\hline Eugene, OR & 44.12 & 57.9 & 228 & 11 & 4627 & 10 \\
\hline Evansville, IN & 38.05 & 61.4 & 1298 & 9 & 4803 & 10 \\
\hline Fairbanks, AK & 64.82 & 41.3 & 29 & 12 & 14095 & 15 \\
\hline Fargo, ND & 46.9 & 49.6 & 547 & 10 & 9069 & 15 \\
\hline Flagstaff, AZ & 35.13 & 53.8 & 106 & 12 & 7430 & 14 \\
\hline Flint, MI & 42.97 & 53.6 & 444 & 11 & 6981 & 13 \\
\hline Fort Smith, AR & 35.33 & 67.1 & 1895 & 8 & 3351 & 7 \\
\hline Fort Wayne, IN & 41 & 55.3 & 657 & 10 & 6391 & 13 \\
\hline Fort Worth, TX & 32.83 & 70.5 & 2415 & 7 & 2304 & 5 \\
\hline Fresno, CA & 36.77 & 69.4 & 1884 & 8 & 2602 & 6 \\
\hline Glasgow, MT & 48.22 & 50.2 & 469 & 11 & 8659 & 15 \\
\hline Goodland, KS & 39.37 & 57.4 & 842 & 10 & 6270 & 13 \\
\hline Grand Island, NE & 40.97 & 57.3 & 925 & 10 & 6420 & 13 \\
\hline Grand Junction, CO & 39.12 & 59.6 & 1145 & 9 & 5676 & 12 \\
\hline Grand Rapids, MI & 42.88 & 53.4 & 508 & 10 & 7148 & 14 \\
\hline Great Falls, MT & 47.48 & 52.1 & 362 & 11 & 7735 & 14 \\
\hline Green Bay, WI & 44.48 & 50.0 & 414 & 11 & 8286 & 15 \\
\hline Greensboro, NC & 36.08 & 62.9 & 1223 & 9 & 4091 & 9 \\
\hline Greenville, SC & 34.9 & 65.3 & 1483 & 9 & 3408 & 7 \\
\hline Guam, PI & 13.55 & 80.9 & 5184 & 1 & 0 & 1 \\
\hline Gulkana, AK & 62.15 & 38.6 & 0 & 12 & 13880 & 15 \\
\hline Harrisburg, PA & 40.22 & 58.2 & 987 & 10 & 5479 & 11 \\
\hline Hartford, CT & 41.93 & 55.9 & 745 & 10 & 6264 & 13 \\
\hline Helena, MT & 46.60 & 51.4 & 328 & 11 & 7802 & 14 \\
\hline Hilo, HI & 19.72 & 76.4 & 3087 & 5 & 0 & 1 \\
\hline
\end{tabular}




\begin{tabular}{|c|c|c|c|c|c|c|}
\hline Location & Latitude & $\begin{array}{l}\text { Annual Average } \\
\text { Temperature }\left({ }^{\circ} \mathrm{F}\right)\end{array}$ & $\begin{array}{c}\text { Cooling- } \\
\text { Degree-Days } \\
\text { (base } 65^{\circ} \mathrm{F} \text { ) }\end{array}$ & $\begin{array}{c}\text { Cooling- } \\
\text { Degree-Days } \\
\text { Bin \# }\end{array}$ & $\begin{array}{c}\text { Heating- } \\
\text { Degree-Days } \\
\text { (base } 65^{\circ} \mathrm{F} \text { ) }\end{array}$ & $\begin{array}{c}\text { Heating- } \\
\text { Degree-Days } \\
\text { Bin \# }\end{array}$ \\
\hline Honolulu, HI & 21.33 & 79.7 & 4329 & 3 & 0 & 1 \\
\hline Houghton, MI & 47.17 & 49.6 & 234 & 11 & 8541 & 15 \\
\hline Houston, TX & 29.98 & 73.4 & 2810 & 6 & 1552 & 4 \\
\hline Huntington, WV & 38.37 & 60.6 & 998 & 10 & 4496 & 9 \\
\hline Huntsville, AL & 34.65 & 65.1 & 1632 & 8 & 3542 & 8 \\
\hline Huron, SD & 44.38 & 52.6 & 530 & 10 & 8235 & 15 \\
\hline Indianapolis, IN & 39.73 & 57.7 & 910 & 10 & 5689 & 12 \\
\hline $\begin{array}{l}\text { International Falls, } \\
\text { MN }\end{array}$ & 48.57 & 44.6 & 125 & 12 & 10435 & 15 \\
\hline Jackson, MS & 32.32 & 69.9 & 2233 & 7 & 2501 & 6 \\
\hline Jacksonville, FL & 30.50 & 73.4 & 2657 & 6 & 1437 & 3 \\
\hline Kahului, HI & 20.90 & 79.2 & 3851 & 4 & 3 & 1 \\
\hline Kalispell, MT & 48.30 & 49.9 & 105 & 12 & 8314 & 15 \\
\hline Kansas City, MO & 39.30 & 60.5 & 1445 & 9 & 5155 & 11 \\
\hline Key West, FL & 24.55 & 79.9 & 4757 & 2 & 62 & 1 \\
\hline King Salmon, AK & 58.68 & 41.5 & 1 & 12 & 11446 & 15 \\
\hline Knoxville, TN & 35.82 & 63.5 & 1366 & 9 & 3662 & 8 \\
\hline Kodiak, AK & 57.75 & 45.1 & 2 & 12 & 8944 & 15 \\
\hline La Crosse, WI & 43.87 & 52.4 & 617 & 10 & 7658 & 14 \\
\hline Lake Charles, LA & 30.12 & 72.1 & 2624 & 6 & 1683 & 4 \\
\hline Lander, WY & 42.82 & 51.7 & 371 & 11 & 7754 & 14 \\
\hline Lansing, MI & 42.78 & 53.9 & 550 & 10 & 7122 & 14 \\
\hline Las Vegas, NV & 36.08 & 73.8 & 3067 & 5 & 2293 & 5 \\
\hline Lewistown, MT & 47.05 & 50.3 & 209 & 11 & 8338 & 15 \\
\hline Lexington, KY & 38.03 & 59.7 & 1005 & 9 & 4994 & 10 \\
\hline Lihue, HI & 21.98 & 77.8 & 3847 & 4 & 0 & 1 \\
\hline Little Rock, AR & 34.73 & 67.3 & 1929 & 8 & 3181 & 7 \\
\hline Long Beach, CA & 33.82 & 67.4 & 943 & 10 & 1309 & 3 \\
\hline Los Angeles, CA & 33.93 & 65.2 & 470 & 11 & 1291 & 3 \\
\hline Louisville, KY & 38.18 & 62.0 & 1300 & 9 & 4441 & 9 \\
\hline Lubbock, TX & 33.65 & 65.7 & 1569 & 8 & 3451 & 7 \\
\hline Lufkin, TX & 31.23 & 72.2 & 2493 & 7 & 1911 & 4 \\
\hline Lynchburg, VA & 37.33 & 61.3 & 1070 & 9 & 4448 & 9 \\
\hline Macon, GA & 32.70 & 69.5 & 2090 & 7 & 2353 & 5 \\
\hline Madison, WI & 43.13 & 52.8 & 521 & 10 & 7495 & 14 \\
\hline Mansfield, $\mathrm{OH}$ & 40.82 & 55.6 & 688 & 10 & 6245 & 13 \\
\hline Mason City, IA & 43.15 & 51.3 & 505 & 10 & 8167 & 15 \\
\hline Massena, NY & 44.93 & 49.5 & 351 & 11 & 8466 & 15 \\
\hline Mcgrath, AK & 62.97 & 39.5 & 14 & 12 & 14206 & 15 \\
\hline Medford, OR & 42.37 & 59.6 & 672 & 10 & 4829 & 10 \\
\hline Memphis, TN & 35.05 & 67.3 & 1999 & 8 & 3108 & 7 \\
\hline Meridian, MS & 32.33 & 69.5 & 1990 & 8 & 2585 & 6 \\
\hline Miami, FL & 25.80 & 78.7 & 4127 & 3 & 141 & 1 \\
\hline Midland, TX & 31.93 & 69.7 & 2032 & 7 & 2772 & 6 \\
\hline Miles City, MT & 46.43 & 52.7 & 598 & 10 & 7783 & 14 \\
\hline Milwaukee, WI & 42.95 & 51.2 & 473 & 11 & 7512 & 14 \\
\hline Minneapolis, MN & 44.88 & 52.0 & 634 & 10 & 7986 & 14 \\
\hline Minot, ND & 48.27 & 49.2 & 309 & 11 & 9092 & 15 \\
\hline Missoula, MT & 46.92 & 51.2 & 274 & 11 & 7888 & 14 \\
\hline Mobile, AL & 30.68 & 71.7 & 2508 & 6 & 1710 & 4 \\
\hline
\end{tabular}




\begin{tabular}{|c|c|c|c|c|c|c|}
\hline Location & Latitude & $\begin{array}{l}\text { Annual Average } \\
\text { Temperature }\left({ }^{\circ} \mathrm{F}\right)\end{array}$ & $\begin{array}{c}\text { Cooling- } \\
\text { Degree-Days } \\
\text { (base } 65^{\circ} \mathrm{F} \text { ) }\end{array}$ & $\begin{array}{c}\text { Cooling- } \\
\text { Degree-Days } \\
\text { Bin \# }\end{array}$ & $\begin{array}{c}\text { Heating- } \\
\text { Degree-Days } \\
\text { (base } 65^{\circ} \mathrm{F} \text { ) }\end{array}$ & $\begin{array}{c}\text { Heating- } \\
\text { Degree-Days } \\
\text { Bin \# }\end{array}$ \\
\hline Moline, IL & 41.45 & 56.8 & 882 & 10 & 6302 & 13 \\
\hline Montgomery, AL & 32.30 & 70.3 & 2104 & 7 & 2096 & 5 \\
\hline Muskegon, MI & 43.17 & 52.9 & 494 & 11 & 7037 & 14 \\
\hline Nashville, TN & 36.12 & 64.4 & 1672 & 8 & 4031 & 9 \\
\hline New Orleans, LA & 29.98 & 72.6 & 2539 & 6 & 1464 & 3 \\
\hline New York City, NY & 40.78 & 57.8 & 1002 & 9 & 5090 & 11 \\
\hline Newark, NJ & 40.70 & 58.5 & 1062 & 9 & 5123 & 11 \\
\hline Nome, AK & 64.50 & 39.5 & 0 & 12 & 13955 & 15 \\
\hline Norfolk, NE & 41.98 & 56.0 & 998 & 9 & 6875 & 7 \\
\hline Norfolk, VA & 36.90 & 64.0 & 1439 & 10 & 3489 & 13 \\
\hline North Bend, OR & 43.42 & 55.4 & 1 & 12 & 4633 & 10 \\
\hline North Platte, NE & 41.13 & 56.9 & 773 & 10 & 6798 & 13 \\
\hline Oklahoma City, OK & 35.40 & 65.5 & 1810 & 8 & 3800 & 8 \\
\hline Olympia, WA & 46.97 & 55.8 & 140 & 12 & 5495 & 11 \\
\hline Omaha, NE & 41.37 & 57.6 & 1051 & 9 & 6047 & 13 \\
\hline Pendleton, OR & 45.68 & 58.3 & 687 & 10 & 5311 & 11 \\
\hline Peoria, IL & 40.67 & 56.4 & 882 & 10 & 6327 & 13 \\
\hline Philadelphia, PA & 39.88 & 59.0 & 1053 & 9 & 5181 & 11 \\
\hline Phoenix, AZ & 33.43 & 79.3 & 3815 & 4 & 1154 & 3 \\
\hline Pierre, SD & 44.38 & 55.2 & 795 & 10 & 7224 & 14 \\
\hline Pittsburgh, PA & 40.50 & 56.3 & 684 & 10 & 5986 & 12 \\
\hline Pocatello, ID & 42.92 & 53.7 & 346 & 11 & 7275 & 14 \\
\hline Port Arthur, TX & 29.95 & 73.0 & 2693 & 6 & 1543 & 4 \\
\hline Portland, ME & 43.65 & 51.6 & 315 & 11 & 7442 & 14 \\
\hline Portland, OR & 45.60 & 57.7 & 279 & 11 & 4461 & 9 \\
\hline Prescott, AZ & 34.65 & 63.6 & 898 & 10 & 4404 & 9 \\
\hline Providence, RI & 41.73 & 55.6 & 609 & 10 & 5986 & 12 \\
\hline Pueblo, CO & 38.28 & 61.2 & 916 & 10 & 5241 & 11 \\
\hline Quillayute, WA & 47.95 & 53.1 & 8 & 12 & 5899 & 12 \\
\hline Raleigh, NC & 35.87 & 64.7 & 1313 & 9 & 3547 & 8 \\
\hline Rapid City, SD & 44.05 & 53.6 & 517 & 10 & 7302 & 14 \\
\hline Redmond, OR & 44.27 & 55.1 & 194 & 12 & 6732 & 13 \\
\hline Reno, NV & 39.50 & 58.8 & 384 & 11 & 5768 & 12 \\
\hline Richmond, VA & 37.50 & 63.2 & 1297 & 9 & 4097 & 9 \\
\hline Roanoke, VA & 37.32 & 62.0 & 1035 & 9 & 4215 & 9 \\
\hline Rochester, MN & 43.92 & 50.4 & 500 & 10 & 8244 & 13 \\
\hline Rochester, NY & 43.12 & 54.0 & 620 & 10 & 6733 & 15 \\
\hline Rock Springs, IL & 41.60 & 49.7 & 185 & 12 & 8371 & 15 \\
\hline Rockford, WY & 42.20 & 54.0 & 628 & 10 & 6934 & 13 \\
\hline Sacramento, CA & 38.52 & 65.9 & 1144 & 9 & 2794 & 6 \\
\hline Saint Cloud, MN & 45.55 & 49.6 & 414 & 11 & 8971 & 15 \\
\hline Salem, OR & 44.92 & 57.5 & 200 & 11 & 4969 & 10 \\
\hline Salt Lake City, UT & 40.77 & 60.0 & 1054 & 9 & 5636 & 12 \\
\hline San Angelo, TX & 31.37 & 69.4 & 2180 & 7 & 2662 & 6 \\
\hline San Antonio, TX & 29.53 & 73.3 & 2863 & 6 & 1679 & 4 \\
\hline San Diego, CA & 32.73 & 66.6 & 766 & 10 & 1076 & 3 \\
\hline San Francisco, CA & 37.62 & 59.3 & 69 & 12 & 3239 & 7 \\
\hline San Juan, PR & 18.43 & 81.9 & 5332 & 1 & 0 & 1 \\
\hline Santa Maria, CA & 34.90 & 61.0 & 59 & 12 & 3159 & 7 \\
\hline Sault Ste Marie, MI & 46.47 & 46.9 & 83 & 12 & 9141 & 15 \\
\hline
\end{tabular}




\begin{tabular}{|c|c|c|c|c|c|c|}
\hline Location & Latitude & $\begin{array}{l}\text { Annual Average } \\
\text { Temperature }\left({ }^{\circ} \mathrm{F}\right)\end{array}$ & $\begin{array}{c}\text { Cooling- } \\
\text { Degree-Days } \\
\text { (base } 65^{\circ} \mathrm{F} \text { ) }\end{array}$ & $\begin{array}{c}\text { Cooling- } \\
\text { Degree-Days } \\
\text { Bin \# } \\
\end{array}$ & $\begin{array}{c}\text { Heating- } \\
\text { Degree-Days } \\
\text { (base } 65^{\circ} \mathrm{F} \text { ) }\end{array}$ & $\begin{array}{c}\text { Heating- } \\
\text { Degree-Days } \\
\text { Bin \# }\end{array}$ \\
\hline Savannah, GA & 32.13 & 71.0 & 2292 & 7 & 1951 & 4 \\
\hline Scottsbluff, NE & 41.87 & 57.0 & 714 & 10 & 6448 & 13 \\
\hline Seattle, WA & 47.45 & 55.6 & 127 & 12 & 4867 & 10 \\
\hline Sheridan, WY & 44.77 & 53.0 & 382 & 11 & 7685 & 14 \\
\hline Shreveport, LA & 32.47 & 70.4 & 2287 & 7 & 2216 & 5 \\
\hline Sioux City, IA & 42.40 & 56.1 & 842 & 10 & 6692 & 13 \\
\hline Sioux Falls, SD & 43.57 & 53.5 & 794 & 10 & 7844 & 14 \\
\hline South Bend, IN & 41.70 & 55.7 & 778 & 10 & 6292 & 13 \\
\hline Spokane, WA & 47.63 & 53.3 & 405 & 11 & 6886 & 13 \\
\hline Springfield, IL & 39.83 & 58.1 & 1171 & 9 & 5887 & 10 \\
\hline Springfield, MO & 37.23 & 62.0 & 1346 & 9 & 4690 & 12 \\
\hline St Louis, MO & 38.75 & 60.8 & 1437 & 9 & 5021 & 11 \\
\hline St Paul Is, AK & 57.15 & 37.6 & 0 & 12 & 11126 & 15 \\
\hline Sterling, VA & 38.95 & 59.9 & 1044 & 9 & 5233 & 11 \\
\hline Syracuse, NY & 43.12 & 52.9 & 483 & 11 & 7038 & 14 \\
\hline Talkeetna, AK & 62.30 & 43.5 & 2 & 12 & 11569 & 15 \\
\hline Tallahassee, FL & 30.38 & 72.5 & 2361 & 7 & 1755 & 4 \\
\hline Tampa, FL & 27.97 & 76.6 & 3311 & 5 & 697 & 2 \\
\hline Toledo, $\mathrm{OH}$ & 41.60 & 54.9 & 610 & 10 & 6753 & 13 \\
\hline Tonopah, NV & 38.07 & 60.1 & 695 & 10 & 5372 & 11 \\
\hline Topeka, KS & 39.07 & 60.6 & 1281 & 9 & 5323 & 11 \\
\hline Traverse City, MI & 44.73 & 51.8 & 458 & 11 & 7789 & 14 \\
\hline Tucson, AZ & 32.12 & 75.0 & 2763 & 6 & 1554 & 4 \\
\hline Tucumcari, NM & 35.18 & 64.7 & 1451 & 9 & 3958 & 8 \\
\hline Tulsa, OK & 36.20 & 65.6 & 1870 & 8 & 3816 & 8 \\
\hline Victoria, TX & 28.85 & 74.6 & 2966 & 6 & 1127 & 3 \\
\hline Waco, TX & 31.62 & 71.6 & 2547 & 6 & 2088 & 5 \\
\hline Waterloo, IA & 42.55 & 53.4 & 587 & 10 & 7245 & 14 \\
\hline West Palm Beach, FL & 26.68 & 78.2 & 3802 & 4 & 236 & 1 \\
\hline Wichita Falls, TX & 33.97 & 69.5 & 2385 & 8 & 3055 & 10 \\
\hline Wichita, KS & 37.65 & 62.5 & 1585 & 7 & 4900 & 7 \\
\hline Wilkes-Barre, PA & 41.33 & 53.5 & 547 & 10 & 6683 & 13 \\
\hline Williamsport, PA & 41.27 & 55.5 & 672 & 10 & 6088 & 13 \\
\hline Wilmington, DE & 39.67 & 59.5 & 1085 & 8 & 5087 & 6 \\
\hline Wilmington, $\mathrm{NC}$ & 34.27 & 68.1 & 1868 & 9 & 2658 & 11 \\
\hline Winnemucca, NV & 40.90 & 58.4 & 604 & 10 & 6444 & 13 \\
\hline Worchester, MA & 42.27 & 52.2 & 389 & 11 & 6949 & 13 \\
\hline Yakima, WA & 46.57 & 57.6 & 417 & 11 & 6060 & 13 \\
\hline Yakutat, AK & 59.52 & 43.8 & 0 & 12 & 9797 & 15 \\
\hline Youngstown, $\mathrm{OH}$ & 41.27 & 53.9 & 518 & 10 & 6695 & 13 \\
\hline
\end{tabular}


Table 5. Bins of heating- and cooling-degree-days.

\begin{tabular}{|l|l|c||l|l|c|}
\hline $\begin{array}{l}\text { Bin } \\
\#\end{array}$ & $\begin{array}{l}\text { Heating-degree-day } \\
\text { range }\end{array}$ & $\begin{array}{l}\text { No. of } \\
\text { Simulations }\end{array}$ & $\begin{array}{l}\text { Bin } \\
\#\end{array}$ & $\begin{array}{l}\text { Cooling-degree-day } \\
\text { range }\end{array}$ & $\begin{array}{l}\text { No. of } \\
\text { Simulations }\end{array}$ \\
\hline 1 & $0<\mathrm{HDD}<500$ & 9 & 1 & $5000<\mathrm{CDD}$ & 2 \\
2 & $500<\mathrm{HDD}<1000$ & 4 & 2 & $4500<\mathrm{CDD}<5000$ & 1 \\
3 & $1000<\mathrm{HDD}<1500$ & 7 & 3 & $4000<\mathrm{CDD}<4500$ & 2 \\
4 & $1500<\mathrm{HDD}<2000$ & 12 & 4 & $3500<\mathrm{CDD}<4000$ & 5 \\
5 & $2000<\mathrm{HDD}<2500$ & 8 & 5 & $3000<\mathrm{CDD}<3500$ & 4 \\
6 & $2500<\mathrm{HDD}<3000$ & 14 & 6 & $2500<\mathrm{CDD}<3000$ & 13 \\
7 & $3000<\mathrm{HDD}<3500$ & 11 & 7 & $2000<\mathrm{CDD}<2500$ & 17 \\
8 & $3500<\mathrm{HDD}<4000$ & 8 & 8 & $1500<\mathrm{CDD}<2000$ & 19 \\
9 & $4000<\mathrm{HDD}<4500$ & 11 & 9 & $1000<\mathrm{CDD}<1500$ & 33 \\
10 & $4500<\mathrm{HDD}<5000$ & 13 & 10 & $500<\mathrm{CDD}<1000$ & 66 \\
11 & $5000<\mathrm{HDD}<5500$ & 19 & 11 & $200<\mathrm{CDD}<500$ & 39 \\
12 & $5500<\mathrm{HDD}<6000$ & 14 & 12 & $0<\mathrm{CDD}<200$ & 35 \\
13 & $6000<\mathrm{HDD}<7000$ & 36 & \multicolumn{3}{|}{} \\
14 & $7000<\mathrm{HDD}<8000$ & 32 & 38 & \\
15 & $8000<\mathrm{HDD}$ & \multicolumn{5}{|l}{} \\
\cline { 1 - 3 }
\end{tabular}


Table 6a. Estimated annual basecase energy use and peak demand, and savings from heat-island reduction measures for residential buildings, ordered by ranges of heating-degree-days. Direct savings include the effect of roof reflectivity and shading by trees. The indirect savings include the effects of increasing the albedo of urban surfaces (roofs and pavements) and increasing urban vegetation. Gas Heat: Gas-heated buildings; Electric Heat: Electrically heated buildings.

\begin{tabular}{|c|c|c|c|c|c|c|c|c|}
\hline \multirow{2}{*}{$\begin{array}{c}\text { HDD Range, } \\
\text { Basecase, and } \\
\text { Savings by Strategy }\end{array}$} & \multicolumn{4}{|c|}{ Gas Heat } & \multicolumn{2}{|c|}{$\begin{array}{c}\text { Electric Heat } \\
\text { Electricity }\left(\mathrm{kWh} / 1000 \mathrm{ft}^{2}\right)\end{array}$} & \multicolumn{2}{|c|}{$\begin{array}{c}\text { Gas \& Electric Heat } \\
\text { Peak Power }\left(W / 1000 \mathrm{ft}^{2}\right)\end{array}$} \\
\hline & $\begin{array}{c}\text { Electricity }(\mathrm{k}) \\
\text { Pre-1980 }\end{array}$ & $\begin{array}{c}\left.11000 \mathrm{ft}^{2}\right) \\
1980^{+}\end{array}$ & $\begin{array}{c}\text { Gas (Therm } \\
\text { Pre-1980 }\end{array}$ & $\begin{array}{c}\left.1000 \mathrm{ft}^{2}\right) \\
1980^{+}\end{array}$ & & & $\begin{array}{r}\text { Peak Power } \\
\text { Pre-1980 }\end{array}$ & $1980^{+}$ \\
\hline \multicolumn{9}{|c|}{ Heating-degree-days group $<500$ (bin $\# 1)$} \\
\hline $\begin{array}{l}\text { Energy use \& demand } \\
\text { Savings }\end{array}$ & 8387 & 5193 & 2 & 0 & 8426 & 5199 & 3151 & 1788 \\
\hline reflective roof savings & 732 & 291 & 0 & 0 & 732 & 291 & 320 & 132 \\
\hline shade tree savings & 298 & 192 & 0 & 0 & 297 & 191 & 79 & 91 \\
\hline indirect savings & 216 & 101 & 0 & 0 & 216 & 101 & 96 & 54 \\
\hline combined savings & 1246 & 584 & 0 & 0 & 1245 & 583 & 495 & 277 \\
\hline \multicolumn{9}{|c|}{ Heating-degree-days group $<1000,>500($ bin \#2) } \\
\hline $\begin{array}{l}\text { Energy use \& demand } \\
\text { Savings }\end{array}$ & 6201 & 3748 & 58 & 15 & 7177 & 3956 & 3658 & 2124 \\
\hline reflective roof savings & 534 & 208 & -1 & 0 & 510 & 203 & 290 & 148 \\
\hline shade tree savings & 291 & 175 & -1 & 0 & 279 & 171 & 72 & 56 \\
\hline indirect savings & 173 & 80 & -1 & 0 & 166 & 79 & 87 & 49 \\
\hline combined savings & 998 & 463 & -3 & 0 & 955 & 453 & 449 & 253 \\
\hline \multicolumn{9}{|c|}{ Heating-degree-days group $<1500,>1000($ bin \#3) } \\
\hline $\begin{array}{l}\text { Energy use \& demand } \\
\text { Savings }\end{array}$ & 3911 & 2172 & 102 & 31 & 5589 & 2589 & 3514 & 1972 \\
\hline reflective roof savings & 447 & 167 & -2 & 0 & 397 & 159 & 322 & 140 \\
\hline shade tree savings & 249 & 147 & -5 & -1 & 209 & 135 & 123 & 107 \\
\hline indirect savings & 146 & 66 & -2 & 0 & 127 & 62 & 107 & 59 \\
\hline combined savings & 842 & 380 & -9 & -1 & 733 & 356 & 552 & 306 \\
\hline \multicolumn{9}{|c|}{ Heating-degree-days group $<2000,>1500($ bin $\# 4)$} \\
\hline $\begin{array}{l}\text { Energy use \& demand } \\
\text { Savings }\end{array}$ & 5236 & 2968 & 163 & 53 & 7998 & 3728 & 3804 & 2118 \\
\hline reflective roof savings & 542 & 213 & -3 & 0 & 463 & 198 & 333 & 145 \\
\hline shade tree savings & 293 & 177 & -6 & -2 & 279 & 168 & 145 & 90 \\
\hline indirect savings & 175 & 82 & -2 & -1 & 156 & 77 & 115 & 56 \\
\hline combined savings & 1010 & 472 & -11 & -3 & 898 & 443 & 593 & 291 \\
\hline \multicolumn{9}{|c|}{ Heating-degree-days group $<2500,>2000($ bin \#5) } \\
\hline $\begin{array}{l}\text { Energy use \& demand } \\
\text { Savings }\end{array}$ & 4674 & 2583 & 219 & 75 & 8510 & 3690 & 4056 & 2272 \\
\hline reflective roof savings & 494 & 188 & -5 & -1 & 379 & 165 & 328 & 143 \\
\hline shade tree savings & 307 & 182 & -8 & -2 & 287 & 170 & 171 & 113 \\
\hline indirect savings & 168 & 78 & -3 & -1 & 140 & 70 & 120 & 61 \\
\hline combined savings & 969 & 448 & -16 & -4 & 806 & 405 & 619 & 317 \\
\hline \multicolumn{9}{|c|}{ Heating-degree-days group $<3000,>2500($ bin \#6) } \\
\hline $\begin{array}{l}\text { Energy use \& demand } \\
\text { Savings }\end{array}$ & 3907 & 2099 & 298 & 107 & 8912 & 3669 & 3698 & 2031 \\
\hline reflective roof savings & 466 & 176 & -7 & -2 & 313 & 141 & 333 & 139 \\
\hline shade tree savings & 282 & 165 & -12 & -4 & 263 & 148 & 145 & 84 \\
\hline indirect savings & 157 & 72 & -5 & -2 & 121 & 61 & 115 & 54 \\
\hline combined savings & 905 & 413 & -24 & -8 & 697 & 350 & 593 & 277 \\
\hline
\end{tabular}




\begin{tabular}{|c|c|c|c|c|c|c|c|c|}
\hline \multirow{3}{*}{$\begin{array}{c}\text { HDD Range, } \\
\text { Basecase, and } \\
\text { Savings by Strategy }\end{array}$} & \multicolumn{4}{|c|}{ Gas Heat } & \multirow{2}{*}{\multicolumn{2}{|c|}{$\begin{array}{c}\text { Electric Heat } \\
\text { Electricity }\left(\mathrm{kWh} / 1000 \mathrm{ft}^{2}\right)\end{array}$}} & \multirow{2}{*}{\multicolumn{2}{|c|}{$\begin{array}{r}\text { Gas \& Electric Heat } \\
\text { Peak Power }\left(W / 1000 \mathrm{ft}^{2}\right.\end{array}$}} \\
\hline & \multicolumn{2}{|c|}{ Electricity $\left(\mathrm{kWh} / 1000 \mathrm{ft}^{2}\right)$} & \multicolumn{2}{|c|}{ Gas $\left(\right.$ Therm $\left./ 1000 \mathrm{ft}^{2}\right)$} & & & & \\
\hline & Pre-1980 & $1980^{+}$ & Pre-1980 & $1980^{+}$ & Pre-1980 & $1980^{+}$ & Pre-1980 & $1980^{+}$ \\
\hline \multicolumn{9}{|c|}{ Heating-degree-days group $<3500,>3000$ (bin \#7) } \\
\hline Energy use \& demand & 3037 & 1640 & 396 & 149 & 9439 & 3808 & 3513 & 1936 \\
\hline Savings & & & & & & & & \\
\hline reflective roof savings & 333 & $\begin{array}{l}126 \\
125\end{array}$ & $\begin{array}{l}-9 \\
-16\end{array}$ & $\begin{array}{l}-2 \\
-5\end{array}$ & $\begin{array}{l}138 \\
192\end{array}$ & $\begin{array}{c}82 \\
109\end{array}$ & $\begin{array}{l}329 \\
154\end{array}$ & $\begin{array}{l}151 \\
121\end{array}$ \\
\hline shade tree savings & 211 & 125 & $\begin{array}{l}-16 \\
-6\end{array}$ & -2 & 69 & 40 & 116 & $\begin{array}{l}121 \\
65\end{array}$ \\
\hline indirect savings & 114 & 53 & $\begin{array}{c}-6 \\
-31\end{array}$ & -9 & 399 & 231 & 599 & 337 \\
\hline \multicolumn{9}{|c|}{ Heating-degree-days group $<4000,>3500$ (bin \#8) } \\
\hline Energy use \& demand & 3343 & 1777 & 472 & 185 & 11225 & 4612 & 3705 & 2020 \\
\hline Savings & נדכת & 列 & $4 / 2$ & 100 & 11220 & 4012 & Sוסנ & 2020 \\
\hline reflective roof savings & 374 & 144 & -10 & -3 & 154 & 81 & 329 & 136 \\
\hline shade tree savings & 250 & 141 & -14 & -6 & 271 & 121 & 202 & 85 \\
\hline indirect savings & 131 & 60 & -6 & -2 & 89 & 42 & 127 & 53 \\
\hline combined savings & 755 & 345 & -30 & -11 & 514 & 244 & 658 & 274 \\
\hline \multicolumn{9}{|c|}{ Heating-degree-days group $<4500,>4000$ (bin \#9) } \\
\hline Energy use \& demand & 2567 & 1274 & 579 & 231 & 11580 & 4678 & 3315 & 1804 \\
\hline Savings $\quad$. & & & & & & & & \\
\hline reflective roof savings & 343 & 125 & -14 & -4 & 81 & 51 & 326 & 131 \\
\hline shade tree savings & 223 & 117 & -15 & -8 & 221 & 110 & 106 & 103 \\
\hline indirect savings & 119 & 51 & -7 & -3 & 63 & 34 & 104 & 56 \\
\hline combined savings & 685 & 293 & -36 & -15 & 365 & 195 & 536 & 290 \\
\hline \multicolumn{9}{|c|}{ Heating-degree-days group $<5000,>4500$ (bin $\# 10$ ) } \\
\hline $\begin{array}{l}\text { Energy use \& demand } \\
\text { Savings }\end{array}$ & 2073 & 1018 & 680 & 281 & 12642 & 5139 & 3308 & 1797 \\
\hline reflective roof savings & 236 & 84 & -14 & -4 & -20 & 10 & 296 & 143 \\
\hline shade tree savings & 181 & 97 & -29 & -14 & 231 & 94 & 237 & 161 \\
\hline indirect savings & 88 & 38 & -11 & -5 & 44 & 22 & 128 & 73 \\
\hline combined savings & 505 & 219 & -54 & -23 & 255 & 126 & 661 & 377 \\
\hline \multicolumn{9}{|c|}{ Heating-degree-days group $<5500,>5000$ (bin \#11) } \\
\hline Energy use \& demand & 2270 & 1134 & 770 & 321 & 14037 & 5916 & 3381 & 1837 \\
\hline Savings $\quad$. & & & & & & & & \\
\hline reflective roof savings & 234 & 84 & -15 & -4 & -43 & 0 & 315 & 132 \\
\hline shade tree savings & 183 & 101 & -24 & -12 & 252 & 101 & 192 & 161 \\
\hline indirect savings & 88 & 39 & -10 & -4 & 44 & 21 & 122 & 70 \\
\hline combined savings & 505 & 224 & -49 & -20 & 253 & 122 & 629 & 363 \\
\hline \multicolumn{9}{|c|}{ Heating-degree-days group $<6000,>5500$ (bin \#12) } \\
\hline $\begin{array}{l}\text { Energy use \& demand } \\
\text { Savings }\end{array}$ & 2020 & 968 & 876 & 379 & 15217 & 6516 & 3262 & 1713 \\
\hline reflective roof savings & 222 & 80 & -16 & -5 & -69 & -13 & 321 & 134 \\
\hline shade tree savings & 185 & 98 & -19 & -9 & 150 & 61 & 140 & 82 \\
\hline indirect savings & 85 & 37 & -9 & -4 & 17 & 10 & 111 & 52 \\
\hline combined savings & 492 & 215 & -44 & -18 & 98 & 58 & 572 & 268 \\
\hline \multicolumn{9}{|c|}{ Heating-degree-days group $<7000,>6000$ (bin \#13) } \\
\hline $\begin{array}{l}\text { Energy use \& demand } \\
\text { Savings }\end{array}$ & 1990 & 945 & 1025 & 456 & 18006 & 7952 & 3444 & 1829 \\
\hline reflective roof savings & 198 & 71 & -17 & -5 & -97 & -25 & 325 & 130 \\
\hline shade tree savings & 190 & 97 & -15 & -10 & 37 & 57 & 135 & 95 \\
\hline indirect savings & 81 & 35 & -8 & -4 & -13 & 7 & 110 & 54 \\
\hline combined savings & 469 & 203 & -40 & -19 & -73 & 39 & 570 & 279 \\
\hline
\end{tabular}




\begin{tabular}{|c|c|c|c|c|c|c|c|c|}
\hline \multirow{2}{*}{$\begin{array}{c}\text { HDD Range, } \\
\text { Basecase, and } \\
\text { Savings by Strategy }\end{array}$} & \multicolumn{4}{|c|}{ Gas Heat } & \multicolumn{2}{|c|}{$\begin{array}{c}\text { Electric Heat } \\
\text { Electricity }\left(\mathrm{kWh} / 1000 \mathrm{ft}^{2}\right)\end{array}$} & \multicolumn{2}{|c|}{$\begin{array}{c}\text { Gas \& Electric Heat } \\
\text { Peak Power }\left(W / 1000 \mathrm{ft}^{2}\right)\end{array}$} \\
\hline & $\begin{array}{l}\text { Pre-1980 } \\
\text { Precting }\end{array}$ & $1980^{+}$ & $\begin{array}{l}\text { Gas }(1 \text { herm } \\
\text { Pre-1980 }\end{array}$ & $\begin{array}{c}1000 \mathrm{ft}) \\
1980^{+}\end{array}$ & $\begin{array}{c}\text { Electricty (K) } \\
\text { Pre-1980 }\end{array}$ & $\begin{array}{l}\left.1 / 1000 \mathrm{ft}^{+}\right) \\
1980^{+}\end{array}$ & $\begin{array}{r}\text { Peak Power } \\
\text { Pre-1980 }\end{array}$ & $1980^{+}$ \\
\hline \multicolumn{9}{|c|}{ Heating-degree-days group $<8000,>7000$ (bin $\# 14$ ) } \\
\hline $\begin{array}{l}\text { Energy use \& demand } \\
\text { Savings }\end{array}$ & 1747 & 802 & 1169 & 529 & 20424 & 9102 & 3310 & 1724 \\
\hline reflective roof savings & 153 & 54 & -20 & -7 & -193 & -64 & 338 & 132 \\
\hline shade tree savings & 168 & 87 & -17 & -9 & -13 & 17 & 207 & 130 \\
\hline indirect savings & 67 & 30 & -9 & -4 & -43 & -10 & 131 & 63 \\
\hline combined savings & 388 & 171 & -46 & -20 & -249 & -57 & 676 & 325 \\
\hline \multicolumn{9}{|c|}{ Heating-degree-days group $>8000$ (bin \#15) } \\
\hline $\begin{array}{l}\text { Energy use \& demand } \\
\text { Savings }\end{array}$ & 1551 & 713 & 1614 & 765 & 28511 & 13549 & 2421 & 1223 \\
\hline reflective roof savings & 67 & 22 & -21 & -7 & -330 & -109 & 344 & 124 \\
\hline shade tree savings & 82 & 41 & -22 & -11 & -227 & -103 & 357 & 197 \\
\hline indirect savings & 31 & 13 & -11 & -5 & -117 & -45 & 168 & 77 \\
\hline combined savings & 180 & 76 & -54 & -23 & -674 & -257 & 869 & 398 \\
\hline
\end{tabular}


Table 6b. Estimated annual basecase energy use and peak demand and savings from heat-island reduction measures for residential buildings, ordered by ranges of cooling-degree-days. Direct savings include the effect of roof reflectivity and shading by trees. The indirect savings include the effects of increasing the albedo of urban surfaces (roofs and pavements) and increasing urban vegetation. Gas Heat: Gas-heated buildings; Electric Heat: Electrically heated buildings.

\begin{tabular}{|c|c|c|c|c|c|c|c|c|}
\hline \multirow{3}{*}{$\begin{array}{c}\text { CDD Range, } \\
\text { Basecase, and } \\
\text { Savings by Strategy }\end{array}$} & \multicolumn{4}{|c|}{ Gas Heat } & \multirow{2}{*}{\multicolumn{2}{|c|}{$\begin{array}{c}\text { Electric Heat } \\
\text { Electricity }\left(\mathrm{kWh} / 1000 \mathrm{ft}^{2}\right)\end{array}$}} & \multirow{2}{*}{\multicolumn{2}{|c|}{$\begin{array}{r}\text { Gas \& Electric Heat } \\
\text { Peak Power }\left(W / 1000 \mathrm{ft}^{2}\right.\end{array}$}} \\
\hline & \multicolumn{2}{|c|}{ Electricity $\left(\mathrm{kWh} / 1000 \mathrm{ft}^{2}\right)$} & \multicolumn{2}{|c|}{ Gas $\left(\right.$ Therm $\left./ 1000 \mathrm{ft}^{2}\right) \mid$} & & & & \\
\hline & Pre-1980 & $1980^{+}$ & Pre-1980 & $1980^{+}$ & Pre-1980 & $1980^{+}$ & Pre-1980 & $1980^{+}$ \\
\hline \multicolumn{9}{|c|}{ Cooling-degree-days group > $5000($ bin $\# 1)$} \\
\hline $\begin{array}{l}\text { Energy use \& demand } \\
\text { Savings }\end{array}$ & 10770 & 6715 & 0 & 0 & 10770 & 6715 & 3235 & 1776 \\
\hline reflective roof savings & 807 & 333 & 0 & 0 & 807 & 333 & 347 & 115 \\
\hline shade tree savings & 260 & 158 & 0 & 0 & 260 & 158 & 30 & 21 \\
\hline indirect savings & 224 & 103 & 0 & 0 & 224 & 103 & 90 & 33 \\
\hline combined savings & 1291 & 594 & 0 & 0 & 1291 & 594 & 467 & 169 \\
\hline \multicolumn{9}{|c|}{ Cooling-degree-days group $>4500,<5000($ bin \#2) } \\
\hline Energy use \& demand & 9603 & 5846 & 1 & 0 & 9623 & 5847 & 3391 & 1939 \\
\hline $\begin{array}{l}\text { Savings } \\
\text { reflective roof savings }\end{array}$ & 755 & 297 & & & 756 & 298 & 305 & 133 \\
\hline shade tree savings & 274 & 212 & 0 & 0 & 274 & $\begin{array}{l}298 \\
213\end{array}$ & $\begin{array}{c}305 \\
21\end{array}$ & $\begin{array}{l}135 \\
231\end{array}$ \\
\hline indirect savings & 216 & 107 & 0 & 0 & 216 & 107 & 78 & 87 \\
\hline combined savings & 1245 & 616 & 0 & 0 & 1246 & 618 & 404 & 451 \\
\hline \multicolumn{9}{|c|}{ Cooling-degree-days group $>4000,<4500($ bin \#3) } \\
\hline $\begin{array}{l}\text { Energy use \& demand } \\
\text { Savings }\end{array}$ & 8225 & 5084 & 3 & 0 & 8274 & 5090 & 3270 & 1840 \\
\hline reflective roof savings & 712 & 282 & 0 & 0 & 712 & 282 & 367 & 140 \\
\hline shade tree savings & 308 & 198 & 0 & 0 & 306 & 198 & 136 & 87 \\
\hline indirect savings & 214 & 101 & 0 & 0 & 214 & 101 & 121 & 54 \\
\hline combined savings & 1234 & 581 & 0 & 0 & 1232 & 581 & 624 & 281 \\
\hline \multicolumn{9}{|c|}{ Cooling-degree-days group $>3500,<4000($ bin \#4) } \\
\hline $\begin{array}{l}\text { Energy use \& demand } \\
\text { Savings }\end{array}$ & 7454 & 4498 & 30 & 8 & 7979 & 4610 & 3631 & 2085 \\
\hline reflective roof savings & 649 & 250 & 0 & 0 & 638 & 247 & 292 & 134 \\
\hline shade tree savings & 372 & 220 & -1 & 0 & 365 & 216 & 129 & 110 \\
\hline indirect savings & 214 & 99 & 0 & 0 & 211 & 97 & 101 & 59 \\
\hline combined savings & 1235 & 569 & -1 & 0 & 1214 & 560 & 522 & 303 \\
\hline \multicolumn{9}{|c|}{ Cooling-degree-days group $>3000,<3500($ bin \#5) } \\
\hline $\begin{array}{l}\text { Energy use \& demand } \\
\text { Savings }\end{array}$ & 6254 & 3647 & 71 & 20 & 7559 & 3946 & 3953 & 2242 \\
\hline reflective roof savings & 630 & 247 & -1 & 0 & 593 & 241 & 313 & 159 \\
\hline shade tree savings & 332 & 203 & -2 & 0 & 315 & 198 & 112 & 91 \\
\hline indirect savings & 202 & 95 & -1 & 0 & 191 & 92 & 102 & 60 \\
\hline combined savings & 1164 & 545 & -4 & 0 & 1099 & 531 & 527 & 310 \\
\hline \multicolumn{9}{|c|}{ Cooling-degree-days group $>2500,<3000($ bin \#6) } \\
\hline $\begin{array}{l}\text { Energy use \& demand } \\
\text { Savings }\end{array}$ & 5381 & 3085 & 145 & 46 & 7840 & 3753 & 3797 & 2146 \\
\hline reflective roof savings & 534 & 210 & -3 & 0 & 466 & 197 & 321 & 146 \\
\hline shade tree savings & 294 & 179 & -5 & -1 & 278 & 171 & 98 & 82 \\
\hline indirect savings & 174 & 82 & -2 & 0 & 156 & 77 & 101 & 55 \\
\hline combined savings & 1002 & 471 & -10 & -1 & 900 & 445 & 520 & 283 \\
\hline \multicolumn{9}{|c|}{ Cooling-degree-days group $>2000,<2500($ bin \#7) } \\
\hline Energy use \& demand & 4541 & 2518 & 243 & 85 & 8703 & 3788 & 3851 & 2143 \\
\hline
\end{tabular}




\begin{tabular}{|c|c|c|c|c|c|c|c|c|}
\hline \multirow{3}{*}{$\begin{array}{c}\text { CDD Range, } \\
\text { Basecase, and } \\
\text { Savings by Strategy }\end{array}$} & \multicolumn{4}{|c|}{ Gas Heat } & \multirow{2}{*}{\multicolumn{2}{|c|}{$\begin{array}{c}\text { Electric Heat } \\
\text { Electricity }\left(\mathrm{kWh} / 1000 \mathrm{ft}^{2}\right)\end{array}$}} & \multirow{2}{*}{\multicolumn{2}{|c|}{$\begin{array}{r}\text { Gas \& Electric Heat } \\
\text { Peak Power }\left(W / 1000 \mathrm{ft}^{2}\right)\end{array}$}} \\
\hline & \multicolumn{2}{|c|}{ Electricity $\left(\mathrm{kWh} / 1000 \mathrm{ft}^{2}\right)$} & \multicolumn{2}{|c|}{ Gas $\left(\right.$ Therm $\left./ 1000 \mathrm{ft}^{2}\right)$} & & & & \\
\hline & Pre-1980 & $1980^{+}$ & Pre-1980 & $1980^{+}$ & Pre-1980 & $1980^{+}$ & Pre-1980 & $1980^{+}$ \\
\hline $\begin{array}{l}\text { Savings } \\
\text { reflective roof savings }\end{array}$ & 495 & 191 & -5 & -1 & 377 & 167 & 331 & 141 \\
\hline shade tree savings & 286 & 171 & -9 & -3 & 280 & 162 & 159 & 102 \\
\hline indirect savings & 164 & 76 & -4 & -1 & 138 & 69 & 118 & 58 \\
\hline combined savings & 945 & 438 & -18 & -5 & 795 & 398 & 608 & 301 \\
\hline \multicolumn{9}{|c|}{ Cooling-degree-days group $>1500,<2000($ bin \#8) } \\
\hline $\begin{array}{l}\text { Energy use \& demand } \\
\text { Savings }\end{array}$ & 3689 & 1994 & 407 & 156 & 10480 & 4377 & 3693 & 2050 \\
\hline reflective roof savings & 418 & 159 & -9 & -2 & 227 & 111 & 321 & 139 \\
\hline shade tree savings & 256 & 149 & -13 & -5 & 261 & 131 & 145 & 73 \\
\hline indirect savings & 142 & 65 & -6 & -2 & 102 & 51 & 112 & 51 \\
\hline combined savings & 816 & 373 & -28 & -9 & 590 & 293 & 578 & 263 \\
\hline \multicolumn{9}{|c|}{ Cooling-degree-days group $>1000,<1500($ bin \#9) } \\
\hline $\begin{array}{l}\text { Energy use \& demand } \\
\text { Savings }\end{array}$ & 2757 & 1411 & 665 & 275 & 13235 & 5607 & 3525 & 1939 \\
\hline reflective roof savings & 317 & 116 & -13 & -4 & 75 & 44 & 311 & 130 \\
\hline shade tree savings & 231 & 126 & -15 & -8 & 213 & 113 & 95 & 90 \\
\hline indirect savings & 115 & 51 & -7 & -3 & 60 & 33 & 97 & 53 \\
\hline combined savings & 663 & 293 & -35 & -15 & 348 & 190 & 503 & 273 \\
\hline \multicolumn{9}{|c|}{ Cooling-degree-days group $>500,<1000($ bin \#10) } \\
\hline $\begin{array}{l}\text { Energy use \& demand } \\
\text { Savings }\end{array}$ & 2045 & 978 & 978 & 436 & 17665 & 7819 & 3454 & 1844 \\
\hline reflective roof savings & 213 & 77 & -16 & -5 & -67 & -14 & 322 & 130 \\
\hline shade tree savings & 195 & 103 & -16 & -9 & 79 & 63 & 163 & 108 \\
\hline indirect savings & 86 & 38 & -8 & -4 & 3 & 10 & 116 & 57 \\
\hline combined savings & 494 & 218 & -40 & -18 & 15 & 59 & 601 & 295 \\
\hline \multicolumn{9}{|c|}{ Cooling-degree-days group $>200,<500($ bin \#11) } \\
\hline $\begin{array}{l}\text { Energy use \& demand } \\
\text { Savings }\end{array}$ & 1606 & 719 & 1130 & 511 & 19768 & 8779 & 3235 & 1681 \\
\hline reflective roof savings & 150 & 51 & -19 & -6 & -191 & -63 & 368 & 142 \\
\hline shade tree savings & 159 & 79 & -19 & -10 & -14 & 7 & 236 & 160 \\
\hline indirect savings & 65 & 27 & -10 & -4 & -43 & -12 & 145 & 72 \\
\hline combined savings & 374 & 157 & -48 & -20 & -248 & -68 & 749 & 374 \\
\hline \multicolumn{9}{|c|}{ Cooling-degree-days group $<200($ bin \#12) } \\
\hline $\begin{array}{l}\text { Energy use \& demand } \\
\text { Savings }\end{array}$ & 1208 & 536 & 1408 & 655 & 23814 & 11063 & 2084 & 1013 \\
\hline reflective roof savings & 43 & 13 & -21 & -7 & -355 & -112 & 317 & 125 \\
\hline shade tree savings & 40 & 20 & -30 & -13 & -165 & -96 & 392 & 215 \\
\hline indirect savings & 17 & 7 & -13 & -5 & -109 & -44 & 170 & 82 \\
\hline combined savings & 100 & 40 & -64 & -25 & -629 & -252 & 879 & 422 \\
\hline
\end{tabular}


Table 6c. Estimated annual basecase carbon emissions and savings from heat-island reduction measures for residential buildings, ordered by ranges of heating-degree-days. Direct savings include the effect of roof reflectivity and shading by trees. The indirect savings include the effects of increasing the albedo of urban surfaces (roofs and pavements) and increasing urban vegetation. Gas Heat: Gas-heated buildings; Electric Heat: Electrically heated buildings.

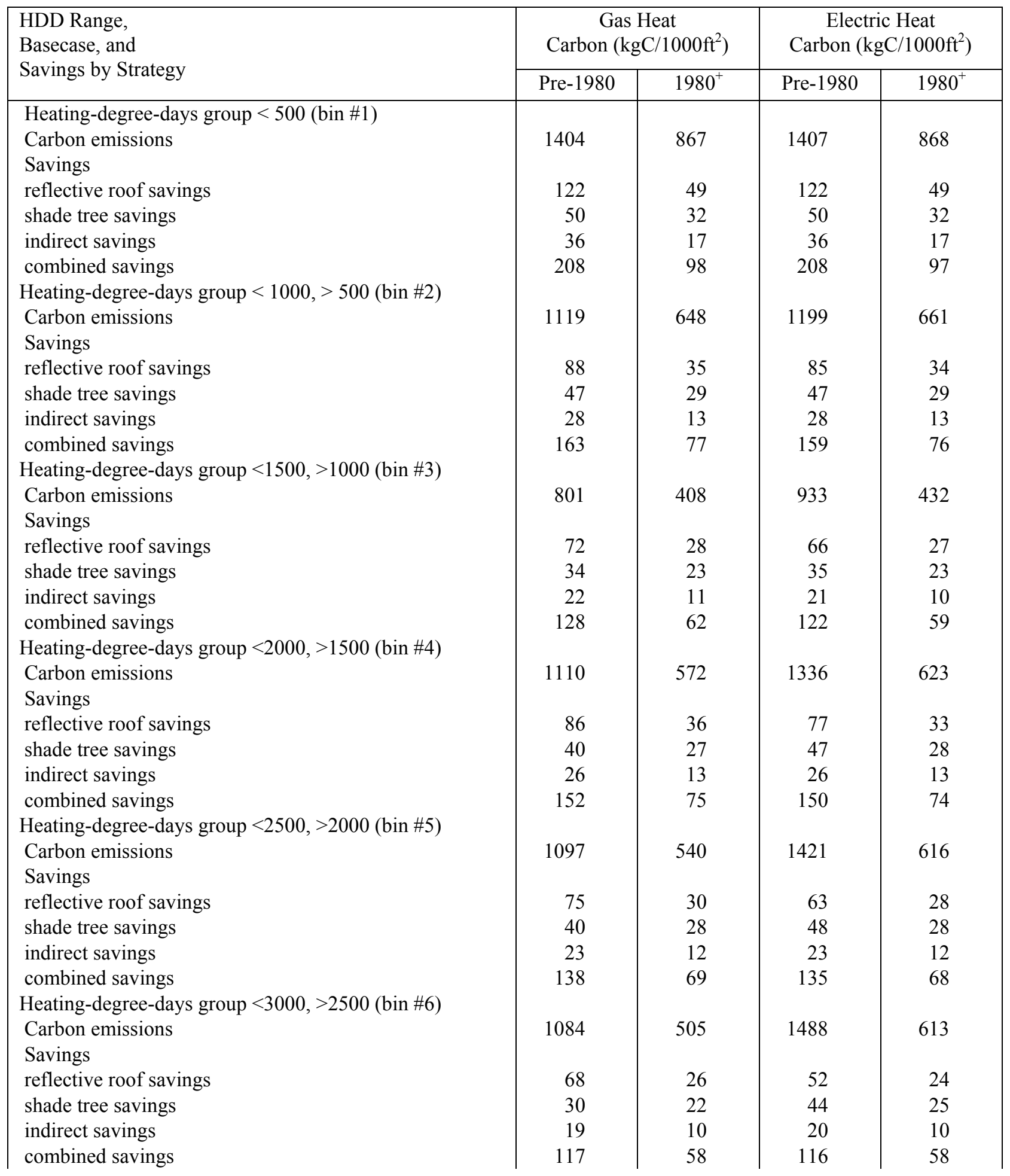




\begin{tabular}{|c|c|c|c|c|}
\hline \multirow{2}{*}{$\begin{array}{l}\text { HDD Range, } \\
\text { Basecase, and } \\
\text { Savings by Strategy }\end{array}$} & \multicolumn{2}{|c|}{$\begin{array}{c}\text { Gas Heat } \\
\text { Carbon }\left(\mathrm{kgC} / 1000 \mathrm{ft}^{2}\right)\end{array}$} & \multicolumn{2}{|c|}{$\begin{array}{c}\text { Electric Heat } \\
\text { Carbon }\left(\mathrm{kgC} / 1000 \mathrm{ft}^{2}\right)\end{array}$} \\
\hline & Pre-1980 & $1980^{+}$ & Pre-1980 & $1980^{+}$ \\
\hline \multicolumn{5}{|l|}{ Heating-degree-days group $<3500,>3000($ bin $\# 7)$} \\
\hline Carbon emissions & 1080 & 489 & 1576 & 636 \\
\hline Savings & & & & \\
\hline reflective roof savings & 43 & 18 & 23 & 14 \\
\hline shade tree savings & 12 & 14 & 32 & 18 \\
\hline indirect savings & 10 & 6 & 12 & 7 \\
\hline combined savings & 65 & 38 & 67 & 39 \\
\hline \multicolumn{5}{|l|}{ Heating-degree-days group $<4000,>3500$ (bin \#8) } \\
\hline Carbon emissions & 1241 & 564 & 1875 & 770 \\
\hline Savings & & & & \\
\hline reflective roof savings & 48 & 20 & 26 & 14 \\
\hline shade tree savings & 21 & 15 & 45 & 20 \\
\hline indirect savings & 13 & 7 & 15 & 7 \\
\hline combined savings & 83 & 41 & 86 & 41 \\
\hline \multicolumn{5}{|l|}{ Heating-degree-days group $<4500,>4000$ (bin $\# 9$ ) } \\
\hline Carbon emissions & 1267 & 547 & 1934 & 781 \\
\hline Savings & & & & \\
\hline reflective roof savings & 37 & 15 & 14 & 9 \\
\hline shade tree savings & 16 & 8 & 37 & 18 \\
\hline indirect savings & 9 & 4 & 11 & 6 \\
\hline combined savings & 62 & 27 & 61 & 33 \\
\hline \multicolumn{5}{|l|}{ Heating-degree-days group $<5000,>4500$ (bin \#10) } \\
\hline Carbon emissions & 1330 & 577 & 2111 & 858 \\
\hline Savings & & & & \\
\hline reflective roof savings & 19 & 8 & -3 & 2 \\
\hline shade tree savings & -12 & -4 & 39 & 16 \\
\hline indirect savings & -1 & 0 & 7 & 4 \\
\hline combined savings & 6 & 4 & 43 & 21 \\
\hline \multicolumn{5}{|l|}{ Heating-degree-days group $<5500,>5000$ (bin \#11) } \\
\hline Carbon emissions & 1493 & 654 & 2344 & 988 \\
\hline Savings & & & & \\
\hline reflective roof savings & 17 & 8 & -7 & 0 \\
\hline shade tree savings & -4 & 0 & 42 & 17 \\
\hline indirect savings & 1 & 1 & 7 & 4 \\
\hline combined savings & 14 & 8 & 42 & 20 \\
\hline \multicolumn{5}{|l|}{ Heating-degree-days group $<6000,>5500$ (bin \#12) } \\
\hline Carbon emissions & 1605 & 710 & 2541 & 1088 \\
\hline \multicolumn{5}{|l|}{ Savings } \\
\hline reflective roof savings & 14 & 6 & -12 & -2 \\
\hline shade tree savings & 3 & 3 & 25 & 10 \\
\hline indirect savings & 2 & 1 & 3 & 2 \\
\hline combined savings & 19 & 11 & 16 & 10 \\
\hline \multicolumn{5}{|l|}{ Heating-degree-days group $<7000,>6000$ (bin \#13) } \\
\hline Carbon emissions & 1816 & 818 & 3007 & 1328 \\
\hline Savings & & & & \\
\hline reflective roof savings & 8 & 5 & -16 & -4 \\
\hline shade tree savings & 10 & 2 & 6 & 10 \\
\hline indirect savings & 2 & 0 & -2 & 1 \\
\hline combined savings & 21 & 7 & -12 & 6 \\
\hline
\end{tabular}




\begin{tabular}{|l|c|c|c|c|}
\hline HDD Range, & \multicolumn{2}{|c|}{$\begin{array}{c}\text { Gas Heat } \\
\text { Carbon }\left(\mathrm{kgC} / 1000 \mathrm{ft}^{2}\right)\end{array}$} & \multicolumn{2}{c|}{ Electric Heat } \\
Carbon $\left(\mathrm{kgC} / 1000 \mathrm{ft}^{2}\right)$
\end{tabular}


Table 6d. Estimated annual basecase carbon emissions and savings from heat-island reduction measures for residential buildings, ordered by ranges of cooling-degree-days. Direct savings include the effect of roof reflectivity and shading by trees. The indirect savings include the effects of increasing the albedo of urban surfaces (roofs and pavements) and increasing urban vegetation. Gas Heat: Gas-heated buildings; Electric Heat: Electrically heated buildings.

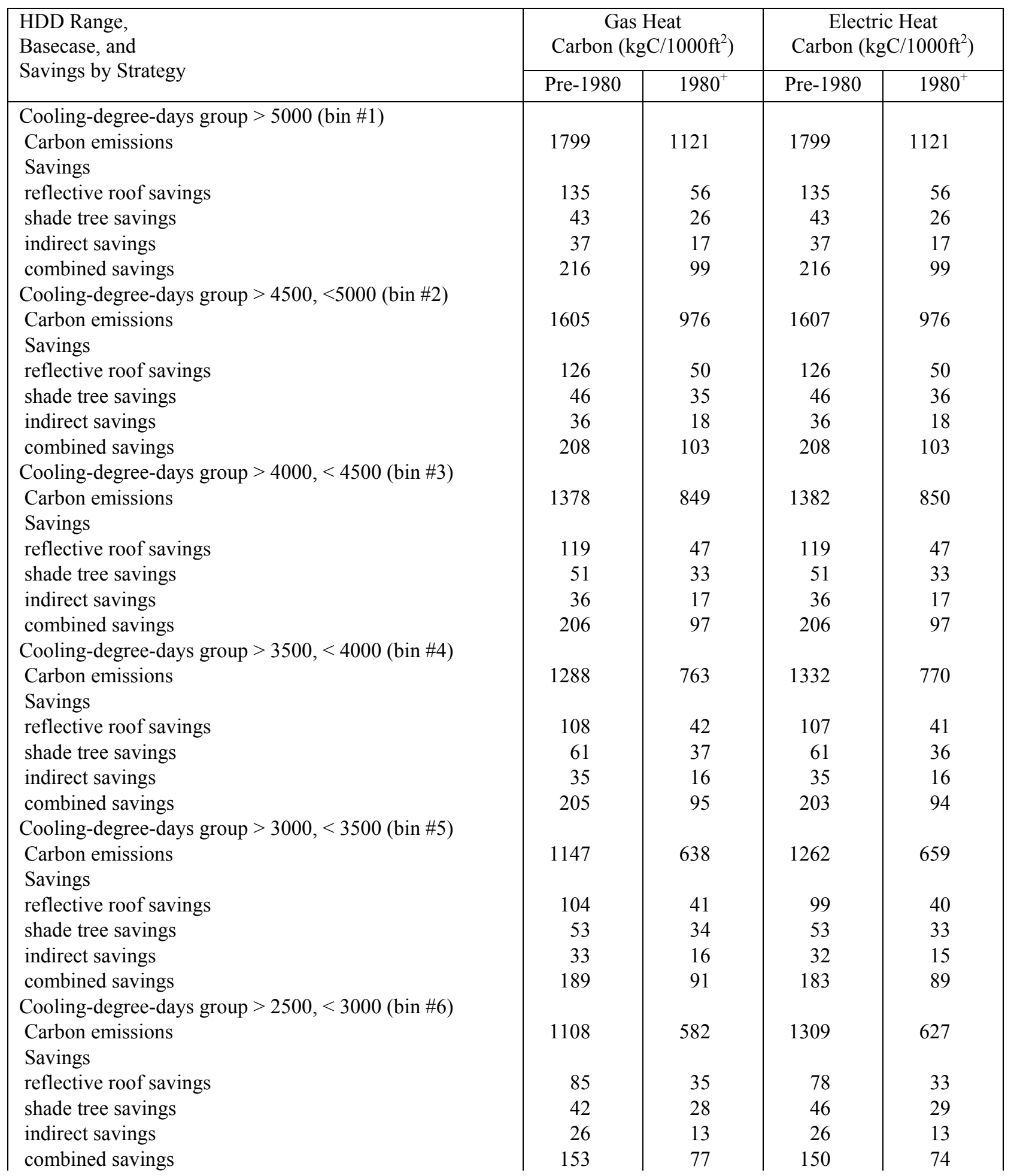




\begin{tabular}{|c|c|c|c|c|}
\hline \multirow{2}{*}{$\begin{array}{l}\text { HDD Range, } \\
\text { Basecase, and } \\
\text { Savings by Strategy }\end{array}$} & \multicolumn{2}{|c|}{$\begin{array}{c}\text { Gas Heat } \\
\text { Carbon }\left(\mathrm{kgC} / 1000 \mathrm{ft}^{2}\right)\end{array}$} & \multicolumn{2}{|c|}{$\begin{array}{c}\text { Electric Heat } \\
\text { Carbon }\left(\mathrm{kgC} / 1000 \mathrm{ft}^{2}\right)\end{array}$} \\
\hline & Pre-1980 & $1980^{+}$ & Pre-1980 & $1980^{+}$ \\
\hline \multicolumn{5}{|l|}{ Cooling-degree-days group $>2000,<2500($ bin $\# 7)$} \\
\hline Carbon emissions & 1110 & 544 & 1453 & 633 \\
\hline Savings & & & & \\
\hline reflective roof savings & 75 & 30 & 63 & 28 \\
\hline shade tree savings & 35 & 24 & 47 & 27 \\
\hline indirect savings & 22 & 11 & 23 & 12 \\
\hline combined savings & 132 & 66 & 133 & 66 \\
\hline \multicolumn{5}{|l|}{ Cooling-degree-days group $>1500,<2000($ bin \#8) } \\
\hline Carbon emissions & 1205 & 559 & 1750 & 731 \\
\hline Savings & & & & \\
\hline reflective roof savings & 57 & 24 & 38 & 19 \\
\hline shade tree savings & 24 & 18 & 44 & 22 \\
\hline indirect savings & 16 & 8 & 17 & 8 \\
\hline combined savings & 96 & 50 & 99 & 49 \\
\hline \multicolumn{5}{|l|}{ Cooling-degree-days group $>1000,<1500($ bin \#9) } \\
\hline Carbon emissions & 1423 & 634 & 2210 & 936 \\
\hline Savings & & & & \\
\hline reflective roof savings & 34 & 14 & 13 & 7 \\
\hline shade tree savings & 17 & 9 & 36 & 19 \\
\hline indirect savings & 9 & 4 & 10 & 6 \\
\hline combined savings & 60 & 27 & 58 & 32 \\
\hline \multicolumn{5}{|l|}{ Cooling-degree-days group $>500,<1000($ bin \#10) } \\
\hline Carbon emissions & 1757 & 794 & 2950 & 1306 \\
\hline Savings & & & & \\
\hline reflective roof savings & 12 & 6 & -11 & -2 \\
\hline shade tree savings & 9 & 4 & 13 & 11 \\
\hline indirect savings & 3 & 1 & 0 & 2 \\
\hline combined savings & 25 & 11 & 2 & 10 \\
\hline \multicolumn{5}{|l|}{ Cooling-degree-days group $>200,<500($ bin \#11) } \\
\hline Carbon emissions & 1903 & 859 & 3301 & 1466 \\
\hline Savings & & & & \\
\hline reflective roof savings & -2 & 0 & -32 & -11 \\
\hline shade tree savings & -1 & -1 & -2 & 1 \\
\hline indirect savings & -3 & -1 & -7 & -2 \\
\hline combined savings & -6 & -3 & -41 & -11 \\
\hline \multicolumn{5}{|l|}{ Cooling-degree-days group $<200$ (bin \#12) } \\
\hline Carbon emissions & 2239 & 1037 & 3977 & 1848 \\
\hline Savings & & & & \\
\hline reflective roof savings & -23 & -8 & -59 & -19 \\
\hline shade tree savings & -37 & -15 & -28 & -16 \\
\hline indirect savings & -16 & -6 & -18 & -7 \\
\hline combined savings & -75 & -30 & -105 & -42 \\
\hline
\end{tabular}


Table 7a. Estimated annual basecase energy use and peak demand and savings from heat-island reduction measures for office buildings, ordered by ranges of heating-degree-days. Direct savings include the effect of roof reflectivity and shading by trees. The indirect savings include the effects of increasing the albedo of urban surfaces (roofs and pavements) and increasing urban vegetation. Gas Heat: Gas-heated buildings; Electric Heat: Electrically heated buildings.

\begin{tabular}{|c|c|c|c|c|c|c|c|c|}
\hline \multirow{2}{*}{$\begin{array}{c}\text { HDD Range, } \\
\text { Basecase, and } \\
\text { Savings by Strategy }\end{array}$} & \multicolumn{4}{|c|}{\begin{tabular}{|c} 
Gas Heat \\
Electricity $\left(\mathrm{kWh} / 1000 \mathrm{ft}^{2}\right) \mid$ Gas $\left(\right.$ Therm $\left./ 1000 \mathrm{ft}^{2}\right)$
\end{tabular}} & \multicolumn{2}{|c|}{$\begin{array}{c}\text { Electric Heat } \\
\text { Electricity }\left(\mathrm{kWh} / 1000 \mathrm{ft}^{2}\right)\end{array}$} & \multicolumn{2}{|c|}{$\begin{array}{l}\text { Gas \& Electric Heat } \\
\text { Peak Power }\left(W / 1000 \mathrm{ft}^{2}\right)\end{array}$} \\
\hline & Pre-1980 & $1980^{+}$ & Pre-1980 & $1980^{+}$ & Pre- 1980 & $1980^{+}$ & Pre-1980 & $1980^{+}$ \\
\hline \multicolumn{9}{|c|}{ Heating-degree-days group $<500($ bin $\# 1)$} \\
\hline $\begin{array}{l}\text { Energy use \& demand } \\
\text { Savings }\end{array}$ & 16839 & 9606 & 2 & 0 & 16863 & 9606 & 6674 & 3834 \\
\hline reflective roof savings & 694 & 242 & 0 & 0 & 693 & 242 & 263 & 95 \\
\hline shade tree savings & 317 & 202 & 0 & 0 & 317 & 202 & 118 & 63 \\
\hline indirect savings & 212 & 93 & 0 & 0 & 212 & 93 & 91 & 38 \\
\hline combined savings & 1,223 & 537 & 0 & 0 & 1222 & 537 & 472 & 196 \\
\hline \multicolumn{9}{|c|}{ Heating-degree-days group $<1000,>500($ bin \#2) } \\
\hline $\begin{array}{l}\text { Energy use \& demand } \\
\text { Savings }\end{array}$ & 15222 & 8252 & 34 & 3 & 15601 & 8289 & 7723 & 4364 \\
\hline reflective roof savings & 662 & 212 & -1 & 0 & 652 & 210 & 306 & 102 \\
\hline shade tree savings & 368 & 279 & 0 & 0 & 364 & 278 & 117 & 192 \\
\hline indirect savings & 216 & 103 & 0 & 0 & 213 & 102 & 102 & 71 \\
\hline combined savings & 1,246 & 594 & -1 & 0 & 1,229 & 590 & 525 & 365 \\
\hline \multicolumn{9}{|c|}{ Heating-degree-days group $<1500,>1000($ bin \#3) } \\
\hline $\begin{array}{l}\text { Energy use \& demand } \\
\text { Savings }\end{array}$ & 13213 & 6587 & 50 & 5 & 13747 & 6636 & 7553 & 4035 \\
\hline reflective roof savings & 776 & 234 & -1 & 0 & 761 & 231 & 370 & 119 \\
\hline shade tree savings & 525 & 266 & -1 & 0 & 520 & 263 & 484 & 181 \\
\hline indirect savings & 273 & 105 & -1 & 0 & 269 & 104 & 205 & 72 \\
\hline combined savings & 1,574 & 605 & -3 & 0 & 1,550 & 598 & 1,059 & 372 \\
\hline \multicolumn{9}{|c|}{ Heating-degree-days group $<2000,>1500$ (bin \#4) } \\
\hline $\begin{array}{l}\text { Energy use \& demand } \\
\text { Savings }\end{array}$ & 13684 & 7057 & 76 & 12 & 14565 & 7191 & 7890 & 4129 \\
\hline reflective roof savings & 739 & 214 & -2 & 0 & 718 & 205 & 359 & 92 \\
\hline shade tree savings & 501 & 259 & -2 & 0 & 494 & 256 & 323 & 138 \\
\hline indirect savings & 260 & 99 & -1 & 0 & 255 & 97 & 164 & 55 \\
\hline combined savings & 1,500 & 572 & -5 & 0 & 1,467 & 558 & 846 & 285 \\
\hline \multicolumn{9}{|c|}{ Heating-degree-days group $<2500,>2000$ (bin \#5) } \\
\hline $\begin{array}{l}\text { Energy use \& demand } \\
\text { Savings }\end{array}$ & 13196 & 6739 & 102 & 17 & 14394 & 6941 & 8428 & 4631 \\
\hline reflective roof savings & 771 & 227 & -3 & -1 & 743 & 216 & 406 & 145 \\
\hline shade tree savings & 544 & 281 & -2 & 0 & 523 & 278 & 247 & 155 \\
\hline indirect savings & 276 & 107 & -1 & 0 & 266 & 104 & 157 & 72 \\
\hline combined savings & 1,591 & 615 & -6 & -1 & 1532 & 598 & 810 & 372 \\
\hline \multicolumn{9}{|c|}{ Heating-degree-days group $<3000,>2500($ bin \#6) } \\
\hline $\begin{array}{l}\text { Energy use \& demand } \\
\text { Savings }\end{array}$ & 11875 & 6028 & 127 & 26 & 13385 & 6334 & 7735 & 4152 \\
\hline reflective roof savings & 733 & 213 & -3 & -1 & 706 & 197 & 421 & 120 \\
\hline shade tree savings & 493 & 247 & -3 & 0 & 456 & 241 & 190 & 94 \\
\hline indirect savings & 257 & 97 & -2 & 0 & 244 & 92 & 147 & 51 \\
\hline combined savings & 1,483 & 557 & -8 & -1 & 1,406 & 530 & 758 & 265 \\
\hline \multicolumn{9}{|c|}{ Heating-degree-days group $<3500,>3000($ bin \#7) } \\
\hline $\begin{array}{l}\text { Energy use \& demand } \\
\text { Savings }\end{array}$ & 10725 & 5346 & 167 & 41 & 12717 & 5828 & 7494 & 4134 \\
\hline
\end{tabular}




\begin{tabular}{|c|c|c|c|c|c|c|c|c|}
\hline \multirow{2}{*}{$\begin{array}{c}\text { HDD Range, } \\
\text { Basecase, and } \\
\text { Savings by Strategy }\end{array}$} & \multirow{2}{*}{\multicolumn{4}{|c|}{$\begin{array}{c}\text { Gas Heat } \\
\text { Electricity }\left(\mathrm{kWh} / 1000 \mathrm{ft}^{2}\right) \mid \text { Gas }\left(\text { Therm/1000 } \mathrm{ft}^{2}\right)\end{array}$}} & \multirow{2}{*}{\multicolumn{2}{|c|}{$\begin{array}{c}\text { Electric Heat } \\
\text { Electricity }\left(\mathrm{kWh} / 1000 \mathrm{ft}^{2}\right)\end{array}$}} & \multirow{2}{*}{\multicolumn{2}{|c|}{$\begin{array}{l}\text { Gas \& Electric Heat } \\
\text { Peak Power }\left(\mathrm{W} / 1000 \mathrm{ft}^{2}\right)\end{array}$}} \\
\hline & Pre-1980 & & Pre-1980 & & & & & \\
\hline reflective roof savings & 662 & 191 & -4 & -2 & 623 & 169 & 363 & 128 \\
\hline shade tree savings & 535 & 237 & -5 & -1 & 495 & 225 & 311 & 139 \\
\hline indirect savings & 251 & 90 & -2 & -1 & 235 & 83 & 162 & 64 \\
\hline combined savings & 1,448 & 518 & -11 & -4 & 1,353 & 477 & 836 & 331 \\
\hline \multicolumn{9}{|c|}{ Heating-degree-days group $<4000,>3500($ bin $\# 8)$} \\
\hline $\begin{array}{l}\text { Energy use \& demand } \\
\text { Savings }\end{array}$ & 10794 & 5489 & 199 & 56 & 13329 & 6211 & 7648 & 4192 \\
\hline reflective roof savings & 640 & 186 & -5 & -2 & 580 & 158 & 334 & 117 \\
\hline shade tree savings & 579 & 249 & -3 & -1 & 566 & 233 & 361 & 125 \\
\hline indirect savings & 256 & 91 & -2 & -1 & 241 & 82 & 167 & 58 \\
\hline combined savings & 1,475 & 526 & -10 & -4 & 1,387 & 473 & 862 & 300 \\
\hline \multicolumn{9}{|c|}{ Heating-degree-days group $<4500,>4000($ bin $\# 9)$} \\
\hline $\begin{array}{l}\text { Energy use \& demand } \\
\text { Savings }\end{array}$ & 9482 & 4759 & 226 & 70 & 12311 & 5618 & 7006 & 3886 \\
\hline reflective roof savings & 659 & 198 & -5 & -2 & 599 & 167 & 381 & 180 \\
\hline shade tree savings & 526 & 241 & -4 & -1 & 485 & 225 & 304 & 255 \\
\hline indirect savings & 249 & 92 & -2 & -1 & 228 & 82 & 164 & 104 \\
\hline combined savings & 1,434 & 531 & -11 & -4 & 1,312 & 474 & 849 & 539 \\
\hline \multicolumn{9}{|c|}{ Heating-degree-days group $<5000,>4500$ (bin \#10) } \\
\hline $\begin{array}{l}\text { Energy use \& demand } \\
\text { Savings }\end{array}$ & 8540 & 4198 & 277 & 89 & 11980 & 5295 & 6827 & 3764 \\
\hline reflective roof savings & 602 & 164 & -5 & -3 & 547 & 128 & 375 & 123 \\
\hline shade tree savings & 616 & 242 & -4 & -2 & 582 & 213 & 384 & 185 \\
\hline indirect savings & 256 & 85 & -2 & -1 & 237 & 72 & 182 & 74 \\
\hline combined savings & 1,474 & 491 & -11 & -6 & 1,366 & 413 & 941 & 382 \\
\hline \multicolumn{9}{|c|}{ Heating-degree-days group $<5500,>5000($ bin \#11) } \\
\hline $\begin{array}{l}\text { Energy use \& demand } \\
\text { Savings }\end{array}$ & 8571 & 4287 & 315 & 112 & 12585 & 5697 & 7071 & 3923 \\
\hline reflective roof savings & 576 & 155 & -6 & -3 & 503 & 112 & 347 & 108 \\
\hline shade tree savings & 600 & 246 & -4 & -3 & 567 & 209 & 381 & 185 \\
\hline indirect savings & 247 & 84 & -3 & -2 & 225 & 67 & 175 & 70 \\
\hline combined savings & 1,423 & 485 & -13 & -8 & 1,295 & 388 & 903 & 363 \\
\hline \multicolumn{9}{|c|}{ Heating-degree-days group $<6000,>5500$ (bin \#12) } \\
\hline $\begin{array}{l}\text { Energy use \& demand } \\
\text { Savings }\end{array}$ & 7966 & 4009 & 354 & 135 & 12577 & 5738 & 6570 & 3662 \\
\hline reflective roof savings & 557 & 155 & -7 & -4 & 463 & 105 & 315 & 119 \\
\hline shade tree savings & 594 & 244 & -6 & -4 & 539 & 196 & 338 & 215 \\
\hline indirect savings & 242 & 84 & -3 & -2 & 210 & 63 & 157 & 80 \\
\hline combined savings & 1,393 & 483 & -16 & -10 & 1,212 & 364 & 810 & 414 \\
\hline \multicolumn{9}{|c|}{ Heating-degree-days group $<7000,>6000($ bin \#13) } \\
\hline $\begin{array}{l}\text { Energy use \& demand } \\
\text { Savings }\end{array}$ & 7796 & 3963 & 434 & $\mid 181$ & 13832 & 6455 & 6878 & 3800 \\
\hline reflective roof savings & 532 & 149 & -8 & -4 & 418 & 91 & 337 & 115 \\
\hline shade tree savings & 622 & 265 & -5 & -5 & 559 & 198 & 377 & 199 \\
\hline indirect savings & 242 & 87 & -3 & -2 & 205 & 61 & 171 & 75 \\
\hline combined savings & 1,396 & 501 & -16 & $\mid-11$ & 1,182 & 350 & 885 & 389 \\
\hline \multicolumn{9}{|c|}{ Heating-degree-days group $<8000,>7000$ (bin \#14) } \\
\hline $\begin{array}{l}\text { Energy use \& demand } \\
\text { Savings }\end{array}$ & 7096 & 3586 & 485 & 207 & 14022 & 6548 & 6468 & 3569 \\
\hline reflective roof savings & 499 & 141 & -10 & -5 & 353 & 70 & 315 & 113 \\
\hline shade tree savings & 668 & 283 & -7 & -6 & 576 & 196 & 437 & 239 \\
\hline indirect savings & 245 & 89 & -4 & -3 & 195 & 56 & 180 & 84 \\
\hline
\end{tabular}




\begin{tabular}{|c|c|c|c|c|c|c|c|c|}
\hline \multirow{2}{*}{$\begin{array}{c}\text { HDD Range, } \\
\text { Basecase, and } \\
\text { Savings by Strategy }\end{array}$} & \multicolumn{4}{|c|}{ Gas Heat } & \multicolumn{2}{|c|}{ Electric Heat } & \multicolumn{2}{|c|}{$\begin{array}{l}\text { Gas \& Electric Heat } \\
\text { Peak Power }\left(W / 1000 \mathrm{ft}^{2}\right)\end{array}$} \\
\hline & Pre-1980 & $1980^{+}$ & Pre-1980 & $1980^{+}$ & Pre-1980 & $1980^{+}$ & Pre-1980 & $1980^{+}$ \\
\hline combined savings & 1,412 & 513 & -21 & -14 & 1,124 & 322 & 932 & 436 \\
\hline \multicolumn{9}{|c|}{ Heating-degree-days group $>8000($ bin $\# 15)$} \\
\hline $\begin{array}{l}\text { Energy use \& demand } \\
\text { Savings }\end{array}$ & 5597 & 2838 & 711 & 341 & 16799 & 8321 & 5265 & 2919 \\
\hline reflective roof savings & 395 & 107 & -13 & -5 & 196 & 18 & 286 & 101 \\
\hline shade tree savings & 510 & 220 & -14 & -10 & 307 & 64 & 404 & 241 \\
\hline indirect savings & 190 & 69 & -7 & -4 & 106 & 17 & 166 & 82 \\
\hline combined savings & 1,095 & 396 & -34 & -19 & 609 & 99 & 856 & 424 \\
\hline
\end{tabular}


Table 7b. Estimated annual basecase energy use and peak demand and savings from heat-island reduction measures for office buildings, ordered by ranges of cooling-degree-days. Direct savings include the effect of roof reflectivity and shading by trees. The indirect savings include the effects of increasing the albedo of urban surfaces (roofs and pavements) and increasing urban vegetation. Gas Heat: Gas-heated buildings; Electric Heat: Electrically heated buildings.

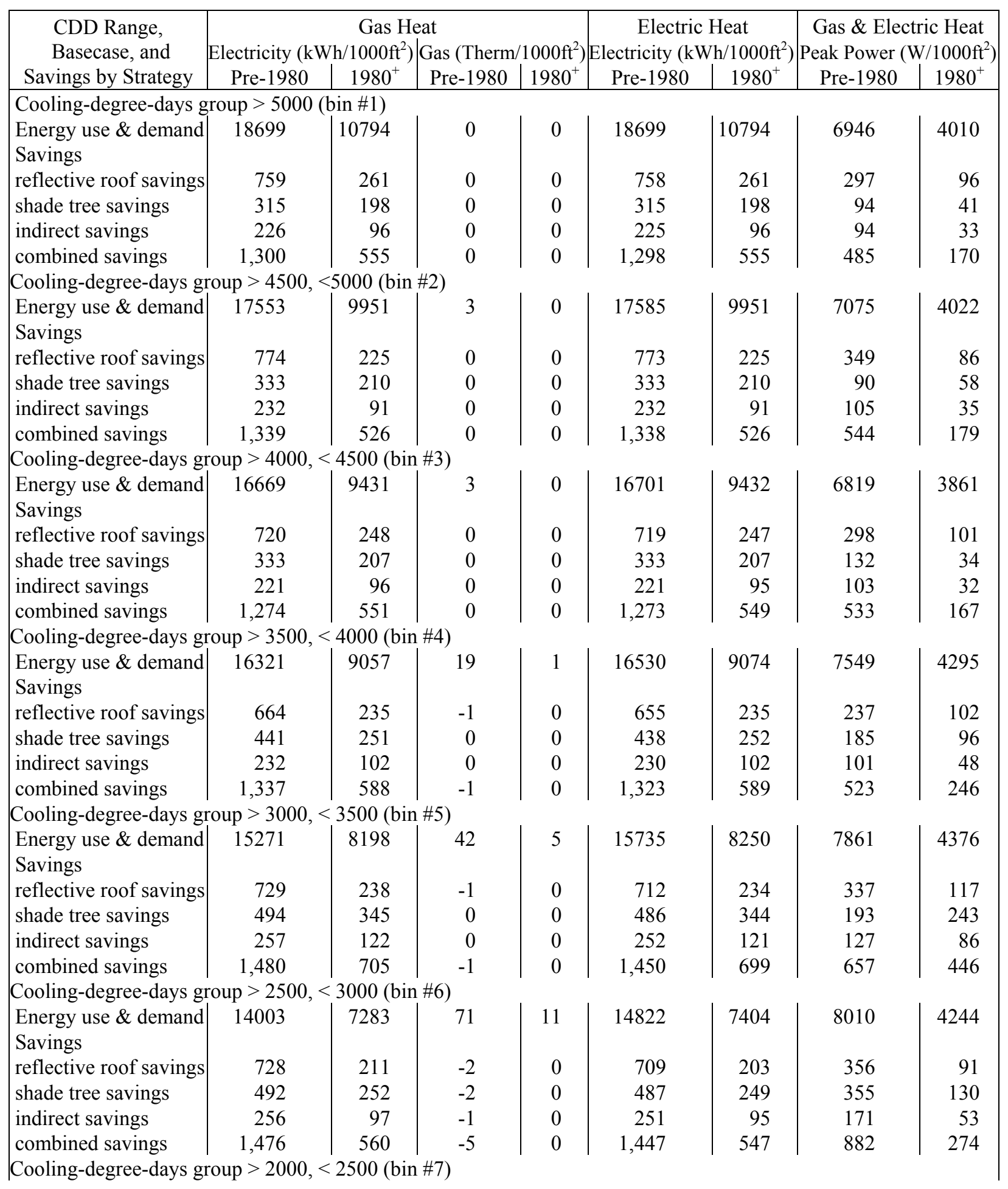




\begin{tabular}{|c|c|c|c|c|c|c|c|c|}
\hline \multirow{3}{*}{$\begin{array}{c}\text { CDD Range, } \\
\text { Basecase, and } \\
\text { Savings by Strategy }\end{array}$} & \multirow{2}{*}{\multicolumn{4}{|c|}{\begin{tabular}{|c|}
\multicolumn{2}{|c|}{ Gas Heat } \\
Electricity $\left(\mathrm{kWh} / 1000 \mathrm{ft}^{2}\right)$ \\
Gas $\left(\right.$ Therm $/ 1000 \mathrm{ft}^{2}$
\end{tabular}}} & \multicolumn{2}{|c|}{ Electric Heat } & \multirow{2}{*}{\multicolumn{2}{|c|}{$\begin{array}{c}\text { Gas \& Electric Heat } \\
\text { Peak Power }\left(W / 1000 \mathrm{ft}^{2}\right)\end{array}$}} \\
\hline & & & & $\left.1000 \mathrm{ft}^{2}\right)$ & Electricity $(\mathrm{k})$ & $\left.\mathrm{h} / 1000 \mathrm{ft}^{2}\right)$ & & \\
\hline & Pre-1980 & $1980^{+}$ & Pre-1980 & $1980^{+}$ & Pre-1980 & $1980^{+}$ & Pre-1980 & $1980^{+}$ \\
\hline $\begin{array}{l}\text { Energy use \& demand } \\
\text { Savings }\end{array}$ & 12812 & 6568 & 109 & 22 & 14115 & 6828 & 8030 & 4334 \\
\hline reflective roof savings & 746 & 220 & -3 & -1 & 721 & 208 & 405 & 133 \\
\hline shade tree savings & 493 & 247 & -2 & 0 & 470 & 242 & 200 & 113 \\
\hline indirect savings & 260 & 98 & -1 & 0 & 250 & 95 & 145 & 59 \\
\hline combined savings & 1,499 & 565 & -6 & -1 & 1,441 & 545 & 750 & 305 \\
\hline \multicolumn{9}{|c|}{ Cooling-degree-days group $>1500,<2000($ bin \#8) } \\
\hline $\begin{array}{l}\text { Energy use \& demand } \\
\text { Savings }\end{array}$ & 11348 & 5787 & 175 & 47 & 13537 & 6378 & 7835 & 4283 \\
\hline reflective roof savings & 677 & 200 & -4 & -2 & 632 & 176 & 361 & 117 \\
\hline shade tree savings & 512 & 244 & -3 & 0 & 483 & 233 & 229 & 115 \\
\hline indirect savings & 250 & 93 & -2 & -1 & 234 & 86 & 142 & 56 \\
\hline combined savings & 1,439 & 537 & -9 & -3 & 1,349 & 495 & 732 & 288 \\
\hline \multicolumn{9}{|c|}{ Cooling-degree-days group $>1000,<1500($ bin \#9) } \\
\hline $\begin{array}{l}\text { Energy use \& demand } \\
\text { Savings }\end{array}$ & 9589 & 4874 & 277 & 97 & 13200 & 6131 & 7381 & 4075 \\
\hline reflective roof savings & 615 & 175 & -6 & -3 & 543 & 137 & 359 & 113 \\
\hline shade tree savings & 576 & 248 & -4 & -2 & 542 & 221 & 314 & 130 \\
\hline indirect savings & 250 & 89 & -3 & -1 & 228 & 75 & 162 & 58 \\
\hline combined savings & 1,441 & 512 & -13 & -6 & 1,313 & 433 & 835 & 301 \\
\hline \multicolumn{9}{|c|}{ Cooling-degree-days group $>500,<1000($ bin \#10) } \\
\hline $\begin{array}{l}\text { Energy use \& demand } \\
\text { Savings }\end{array}$ & 8069 & 4075 & 418 & 174 & 13963 & 6532 & 6966 & 3839 \\
\hline reflective roof savings & 535 & 154 & -8 & -4 & 423 & 97 & 326 & 121 \\
\hline shade tree savings & 619 & 266 & -5 & -4 & 557 & 206 & 392 & 203 \\
\hline indirect savings & 242 & 88 & -3 & -2 & 206 & 64 & 172 & 78 \\
\hline combined savings & 1,396 & 508 & -16 & -10 & 1,186 & 367 & 890 & 402 \\
\hline \multicolumn{9}{|c|}{ Cooling-degree-days group $>200,<500($ bin \#11) } \\
\hline $\begin{array}{l}\text { Energy use \& demand } \\
\text { Savings }\end{array}$ & 7042 & 3532 & 471 & 200 & 13790 & 6416 & 6269 & 3468 \\
\hline reflective roof savings & 517 & 145 & -10 & -4 & 375 & 76 & 327 & 117 \\
\hline shade tree savings & 658 & 282 & -7 & -6 & 564 & 191 & 448 & 265 \\
\hline indirect savings & 247 & 90 & -4 & -3 & 197 & 56 & 186 & 92 \\
\hline combined savings & 1,422 & 517 & -21 & -13 & 1,136 & 323 & 961 & 474 \\
\hline \multicolumn{9}{|c|}{ Cooling-degree-days group < 200 (bin \#12) } \\
\hline $\begin{array}{l}\text { Energy use \& demand } \\
\text { Savings }\end{array}$ & 5439 & 2612 & 597 & 274 & 14496 & 6917 & 4757 & 2653 \\
\hline reflective roof savings & 443 & 109 & -10 & -5 & 292 & 38 & 314 & 110 \\
\hline shade tree savings & 478 & 190 & -14 & -9 & 290 & 56 & 415 & 272 \\
\hline indirect savings & 193 & 63 & -6 & -4 & 122 & 20 & 175 & 92 \\
\hline combined savings & 1,114 & 362 & -30 & -18 & 704 & 114 & 904 & 474 \\
\hline
\end{tabular}


Table 7c. Estimated annual basecase carbon emissions and savings from heat-island reduction measures for office buildings, ordered by ranges of heating-degree-days. Direct savings include the effect of roof reflectivity and shading by trees. The indirect savings include the effects of increasing the albedo of urban surfaces (roofs and pavements) and increasing urban vegetation. Gas Heat: Gas-heated buildings; Electric Heat: Electrically heated buildings.

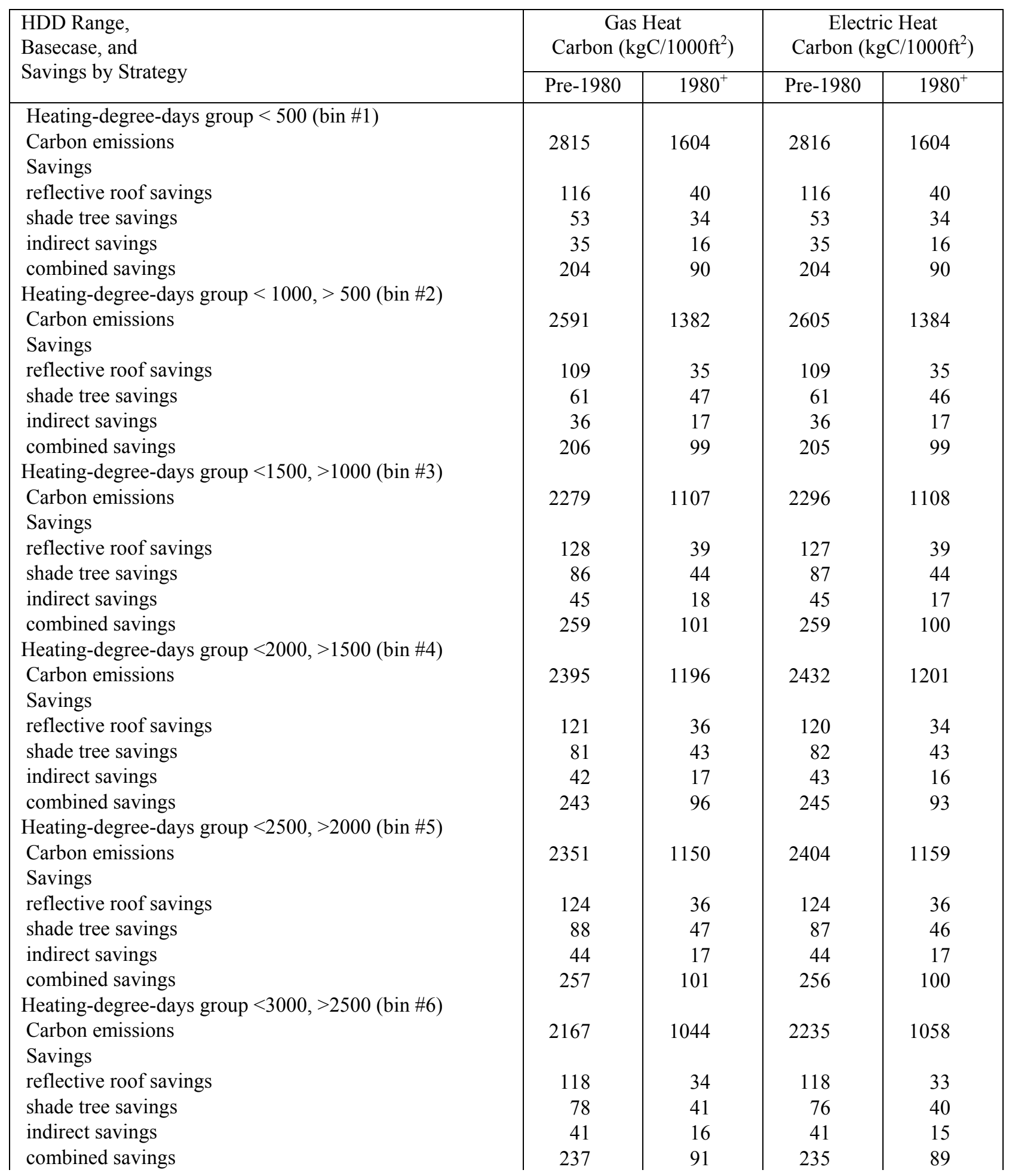




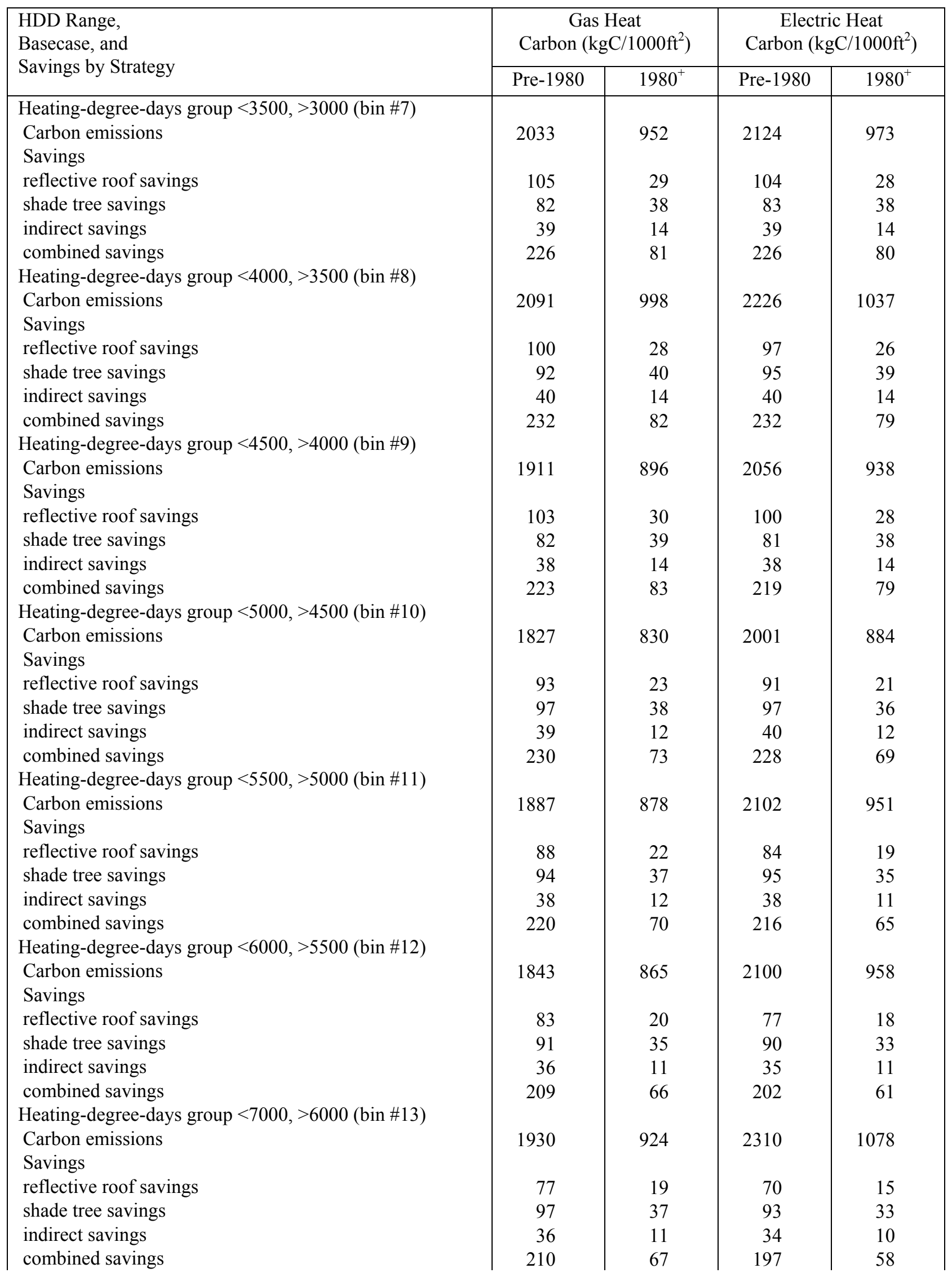




\begin{tabular}{|l|c|c|c|c|}
\hline HDD Range, & \multicolumn{2}{|c|}{$\begin{array}{c}\text { Gas Heat } \\
\text { Carbon }\left(\mathrm{kgC} / 1000 \mathrm{ft}^{2}\right)\end{array}$} & \multicolumn{2}{c|}{ Electric Heat } \\
Carbon $\left(\mathrm{kgC} / 1000 \mathrm{ft}^{2}\right)$
\end{tabular}


Table 7d. Estimated annual basecase carbon emissions and savings from heat-island reduction measures for office buildings, ordered by ranges of cooling-degree-days. Direct savings include the effect of roof reflectivity and shading by trees. The indirect savings include the effects of increasing the albedo of urban surfaces (roofs and pavements) and increasing urban vegetation. Gas Heat: Gas-heated buildings; Electric Heat: Electrically heated buildings.

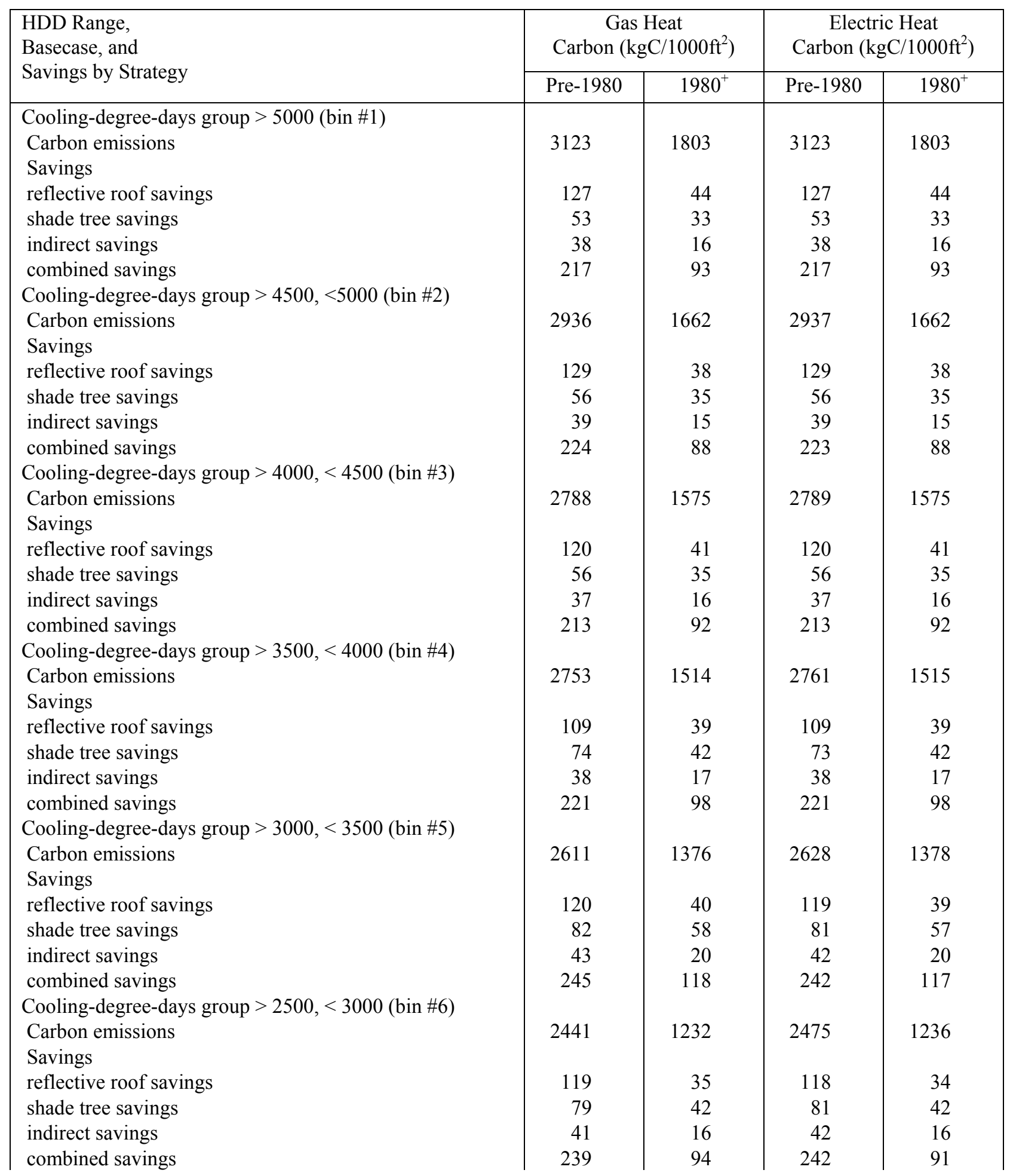




\begin{tabular}{|c|c|c|c|c|}
\hline \multirow{2}{*}{$\begin{array}{l}\text { HDD Range, } \\
\text { Basecase, and } \\
\text { Savings by Strategy }\end{array}$} & \multicolumn{2}{|c|}{$\begin{array}{c}\text { Gas Heat } \\
\text { Carbon }\left(\mathrm{kgC} / 1000 \mathrm{ft}^{2}\right)\end{array}$} & \multicolumn{2}{|c|}{$\begin{array}{c}\text { Electric Heat } \\
\text { Carbon }\left(\mathrm{kgC} / 1000 \mathrm{ft}^{2}\right)\end{array}$} \\
\hline & Pre-1980 & $1980^{+}$ & Pre-1980 & $1980^{+}$ \\
\hline \multicolumn{5}{|l|}{ Cooling-degree-days group $>2000,<2500($ bin $\# 7)$} \\
\hline Carbon emissions & 2297 & 1129 & 2357 & 1140 \\
\hline Savings & & & & \\
\hline reflective roof savings & 120 & 35 & 120 & 35 \\
\hline shade tree savings & 79 & 41 & 78 & 40 \\
\hline indirect savings & 42 & 16 & 42 & 16 \\
\hline combined savings & 241 & 93 & 241 & 91 \\
\hline \multicolumn{5}{|l|}{ Cooling-degree-days group $>1500,<2000($ bin \#8) } \\
\hline Carbon emissions & 2148 & 1034 & 2261 & 1065 \\
\hline Savings & & & & \\
\hline reflective roof savings & 107 & 31 & 106 & 29 \\
\hline shade tree savings & 81 & 41 & 81 & 39 \\
\hline indirect savings & 39 & 15 & 39 & 14 \\
\hline combined savings & 228 & 86 & 225 & 83 \\
\hline \multicolumn{5}{|l|}{ Cooling-degree-days group $>1000,<1500($ bin \#9) } \\
\hline Carbon emissions & 2002 & 954 & 2204 & 1024 \\
\hline Savings & & & & \\
\hline reflective roof savings & 94 & 25 & 91 & 23 \\
\hline shade tree savings & 90 & 39 & 91 & 37 \\
\hline indirect savings & 38 & 13 & 38 & 13 \\
\hline combined savings & 223 & 76 & 219 & 72 \\
\hline \multicolumn{5}{|l|}{ Cooling-degree-days group $>500,<1000($ bin \#10) } \\
\hline Carbon emissions & 1952 & 932 & 2332 & 1091 \\
\hline Savings & & & & \\
\hline reflective roof savings & 78 & 20 & 71 & 16 \\
\hline shade tree savings & 96 & 39 & 93 & 34 \\
\hline indirect savings & 36 & 12 & 34 & 11 \\
\hline combined savings & 210 & 70 & 198 & 61 \\
\hline \multicolumn{5}{|l|}{ Cooling-degree-days group $>200,<500($ bin \#11) } \\
\hline Carbon emissions & 1858 & 879 & 2303 & 1071 \\
\hline Savings & & & & \\
\hline reflective roof savings & 72 & 18 & 63 & 13 \\
\hline shade tree savings & 100 & 38 & 94 & 32 \\
\hline indirect savings & 35 & 11 & 33 & 9 \\
\hline combined savings & 207 & 68 & 190 & 54 \\
\hline \multicolumn{5}{|l|}{ Cooling-degree-days group $<200$ (bin \#12) } \\
\hline Carbon emissions & 1772 & 833 & 2421 & 1155 \\
\hline Savings & & & & \\
\hline reflective roof savings & 60 & 11 & 49 & 6 \\
\hline shade tree savings & 60 & 19 & 48 & 9 \\
\hline indirect savings & 24 & 5 & 20 & 3 \\
\hline combined savings & 143 & 35 & 118 & 19 \\
\hline
\end{tabular}


Table 8a. Estimated annual basecase energy use and peak demand and savings from heat-island reduction measures for retail store buildings, ordered by ranges of heating-degree-days. Direct savings include the effect of roof reflectivity and shading by trees. The indirect savings include the effects of increasing the albedo of urban surfaces (roofs and pavements) and increasing urban vegetation. Gas Heat: Gas-heated buildings; Electric Heat: Electrically heated buildings.

\begin{tabular}{|c|c|c|c|c|c|c|c|c|}
\hline \multirow{2}{*}{$\begin{array}{c}\text { HDD Range, } \\
\text { Basecase, and } \\
\text { Savings by Strategy }\end{array}$} & \multicolumn{4}{|c|}{\begin{tabular}{|c} 
Gas Heat \\
Electricity $\left(\mathrm{kWh} / 1000 \mathrm{ft}^{2}\right) \mid$ Gas $\left(\right.$ Therm $\left./ 1000 \mathrm{ft}^{2}\right)$
\end{tabular}} & \multicolumn{2}{|c|}{$\begin{array}{c}\text { Electric Heat } \\
\text { Electricity }\left(\mathrm{kWh} / 1000 \mathrm{ft}^{2}\right.\end{array}$} & \multicolumn{2}{|c|}{$\begin{array}{l}\text { Gas \& Electric Heat } \\
\text { Peak Power }\left(\mathrm{W} / 1000 \mathrm{ft}^{2}\right)\end{array}$} \\
\hline & Pre-1980 & $1980^{+}$ & Pre-1980 & $1980^{+}$ & Pre-1980 & $1980^{+}$ & Pre-1980 & $1980^{+}$ \\
\hline \multicolumn{9}{|c|}{ Heating-degree-days group $<500($ bin $\# 1)$} \\
\hline Energy use \& demand & 15712 & 8013 & 0 & 0 & 15717 & 8013 & 4546 & 2328 \\
\hline reflective roof savings & 923 & 309 & 0 & 0 & 923 & 309 & 283 & 90 \\
\hline shade tree savings & 320 & 195 & 0 & 0 & 320 & 195 & 94 & 67 \\
\hline indirect savings & 261 & 106 & 0 & 0 & 261 & 106 & 90 & 38 \\
\hline combined savings & 1504 & 610 & 0 & 0 & 1504 & 610 & 467 & 195 \\
\hline \multicolumn{9}{|c|}{ Heating-degree-days group $<1000,>500($ bin $\# 2)$} \\
\hline $\begin{array}{l}\text { Energy use \& demand } \\
\text { Savings }\end{array}$ & 14694 & 7098 & 12 & 0 & 14823 & 7102 & 5311 & 2736 \\
\hline reflective roof savings & 833 & 265 & 0 & 0 & 828 & 266 & 251 & 96 \\
\hline shade tree savings & 269 & 147 & 0 & 0 & 270 & 147 & 76 & 47 \\
\hline indirect savings & 231 & 87 & 0 & 0 & 231 & 87 & 78 & 34 \\
\hline combined savings & 1333 & 499 & 0 & 0 & 1329 & 500 & 405 & 177 \\
\hline \multicolumn{9}{|c|}{ Heating-degree-days group $<1500,>1000($ bin \#3) } \\
\hline $\begin{array}{l}\text { Energy use \& demand } \\
\text { Savings }\end{array}$ & 12936 & 5759 & 16 & 0 & 13110 & 5763 & 5077 & 2500 \\
\hline reflective roof savings & 1014 & 289 & 0 & 0 & 1008 & 290 & 380 & 99 \\
\hline shade tree savings & 415 & 186 & 0 & 0 & 417 & 186 & 134 & 77 \\
\hline indirect savings & 300 & 100 & 0 & 0 & 299 & 100 & 123 & 42 \\
\hline combined savings & 1729 & 575 & 0 & 0 & 1724 & 576 & 637 & 218 \\
\hline \multicolumn{9}{|c|}{ Heating-degree-days group $<2000,>1500($ bin $\# 4)$} \\
\hline $\begin{array}{l}\text { Energy use \& demand } \\
\text { Savings }\end{array}$ & 13486 & 6168 & 30 & 0 & 13826 & 6177 & 5402 & 2672 \\
\hline reflective roof savings & 993 & 298 & -1 & 0 & 981 & 298 & 349 & 124 \\
\hline shade tree savings & 391 & 190 & 0 & 0 & 392 & 191 & 138 & 59 \\
\hline indirect savings & 291 & 102 & 0 & 0 & 288 & 103 & 117 & 44 \\
\hline combined savings & 1675 & 590 & -1 & 0 & 1661 & 592 & 604 & 227 \\
\hline \multicolumn{9}{|c|}{ Heating-degree-days group $<2500,>2000($ bin $\# 5)$} \\
\hline $\begin{array}{l}\text { Energy use \& demand } \\
\text { Savings }\end{array}$ & 13090 & 5792 & 40 & 0 & 13562 & 5801 & 5750 & 2835 \\
\hline reflective roof savings & 1010 & 283 & -2 & 0 & 986 & 283 & 388 & 120 \\
\hline shade tree savings & 396 & 197 & 0 & 0 & 392 & 197 & 150 & 81 \\
\hline indirect savings & 295 & 101 & -1 & 0 & 289 & 101 & 129 & 48 \\
\hline combined savings & 1701 & 581 & -3 & 0 & 1667 & 581 & 667 & 249 \\
\hline \multicolumn{9}{|c|}{ Heating-degree-days group $<3000,>2500($ bin \#6) } \\
\hline $\begin{array}{l}\text { Energy use \& demand } \\
\text { Savings }\end{array}$ & 11888 & 5217 & 51 & 1 & 12500 & 5239 & 5268 & 2573 \\
\hline reflective roof savings & 977 & 265 & -3 & 0 & 944 & 263 & 349 & 112 \\
\hline shade tree savings & 364 & 169 & 0 & 0 & 358 & 170 & 104 & 33 \\
\hline indirect savings & 282 & 91 & -1 & 0 & 273 & 91 & 109 & 35 \\
\hline combined savings & 1623 & 525 & -4 & 0 & 1575 & 524 & 562 & 180 \\
\hline \multicolumn{9}{|c|}{ Heating-degree-days group $<3500,>3000($ bin \#7) } \\
\hline $\begin{array}{l}\text { Energy use \& demand } \\
\text { Savings }\end{array}$ & 10787 & 4580 & 74 & 4 & 11699 & 4637 & 5153 & 2530 \\
\hline
\end{tabular}




\begin{tabular}{|c|c|c|c|c|c|c|c|c|}
\hline \multirow{2}{*}{$\begin{array}{c}\text { HDD Range, } \\
\text { Basecase, and } \\
\text { Savings by Strategy }\end{array}$} & \multicolumn{4}{|c|}{\begin{tabular}{|c} 
Gas Heat \\
Electricity $\left(\mathrm{kWh} / 1000 \mathrm{ft}^{2}\right) \mid$ Gas $\left(\right.$ Therm/1000 $\left.\mathrm{ft}^{2}\right)$
\end{tabular}} & \multirow{2}{*}{\multicolumn{2}{|c|}{$\begin{array}{c}\text { Electric Heat } \\
\text { Electricity }\left(\mathrm{kWh} / 1000 \mathrm{ft}^{2}\right)\end{array}$}} & \multirow{2}{*}{\multicolumn{2}{|c|}{$\begin{array}{l}\text { Gas \& Electric Heat } \\
\text { Peak Power }\left(\mathrm{W} / 1000 \mathrm{ft}^{2}\right)\end{array}$}} \\
\hline & & & Pre-1980 & $1980^{+}$ & & & & \\
\hline reflective roof savings & 902 & 248 & -3 & 0 & 864 & 241 & 360 & 123 \\
\hline shade tree savings & 393 & 178 & 0 & 0 & 389 & 177 & 130 & 56 \\
\hline indirect savings & 272 & 89 & -1 & 0 & 263 & 88 & 118 & 43 \\
\hline combined savings & 1567 & 515 & -4 & 0 & 1516 & 506 & 608 & 222 \\
\hline \multicolumn{9}{|c|}{ Heating-degree-days group $<4000,>3500$ (bin \#8) } \\
\hline $\begin{array}{l}\text { Energy use \& demand } \\
\text { Savings }\end{array}$ & 10813 & 4764 & 94 & 7 & 12024 & 4883 & 5228 & 2617 \\
\hline reflective roof savings & 878 & 239 & -5 & 0 & 815 & 227 & 305 & 93 \\
\hline shade tree savings & 362 & 183 & 0 & 0 & 359 & 181 & 115 & 93 \\
\hline indirect savings & 260 & 89 & -1 & 0 & 247 & 86 & 101 & 45 \\
\hline combined savings & 1500 & 511 & -6 & 0 & 1421 & 494 & 521 & 231 \\
\hline \multicolumn{9}{|c|}{ Heating-degree-days group $<4500,>4000$ (bin \#9) } \\
\hline $\begin{array}{l}\text { Energy use \& demand } \\
\text { Savings }\end{array}$ & 9662 & 4174 & 108 & 7 & 11059 & 4282 & 4830 & 2384 \\
\hline reflective roof savings & 893 & 245 & -5 & -1 & 842 & 230 & 365 & 126 \\
\hline shade tree savings & 404 & 179 & 0 & 0 & 404 & 176 & 140 & 70 \\
\hline indirect savings & 272 & 89 & -1 & 0 & 262 & 85 & 121 & 47 \\
\hline combined savings & 1569 & 513 & -6 & -1 & 1508 & 491 & 626 & 243 \\
\hline \multicolumn{9}{|c|}{ Heating-degree-days group $<5000,>4500$ (bin \#10) } \\
\hline $\begin{array}{l}\text { Energy use \& demand } \\
\text { Savings }\end{array}$ & 8910 & 3716 & 138 & 14 & 10659 & 3916 & 4825 & 2375 \\
\hline reflective roof savings & 813 & 211 & -5 & -1 & 755 & 192 & 338 & 124 \\
\hline shade tree savings & 485 & 202 & 0 & 0 & 491 & 199 & 200 & 116 \\
\hline indirect savings & 273 & 87 & -1 & 0 & 262 & 82 & 129 & 58 \\
\hline combined savings & 1571 & 500 & -6 & -1 & 1508 & 473 & 667 & 298 \\
\hline \multicolumn{9}{|c|}{ Heating-degree-days group $<5500,>5000($ bin \#11) } \\
\hline $\begin{array}{l}\text { Energy use \& demand } \\
\text { Savings }\end{array}$ & 8805 & 3754 & 169 & 22 & 11026 & 4071 & 4959 & 2440 \\
\hline reflective roof savings & 793 & 203 & -6 & -2 & 732 & 172 & 350 & 107 \\
\hline shade tree savings & 438 & 183 & 0 & 0 & 441 & 175 & 180 & 87 \\
\hline indirect savings & 259 & 81 & -2 & -1 & 246 & 73 & 127 & 47 \\
\hline combined savings & 1490 & 467 & -8 & -3 & 1419 & 420 & 657 & 241 \\
\hline \multicolumn{9}{|c|}{ Heating-degree-days group $<6000,>5500$ (bin \#12) } \\
\hline $\begin{array}{l}\text { Energy use \& demand } \\
\text { Savings }\end{array}$ & 8152 & 3509 & 196 & 34 & 10737 & 3974 & 4583 & 2257 \\
\hline reflective roof savings & 754 & 199 & -7 & -3 & 676 & 159 & 313 & 106 \\
\hline shade tree savings & 423 & 174 & -1 & 0 & 423 & 163 & 172 & 78 \\
\hline indirect savings & 247 & 78 & -2 & -1 & 231 & 68 & 116 & 44 \\
\hline combined savings & 1424 & 451 & -10 & -4 & 1330 & 390 & 601 & 228 \\
\hline \multicolumn{9}{|c|}{ Heating-degree-days group $<7000,>6000($ bin \#13) } \\
\hline $\begin{array}{l}\text { Energy use \& demand } \\
\text { Savings }\end{array}$ & 7918 & 3492 & 255 & 58 & 11493 & 4353 & 4836 & 2395 \\
\hline reflective roof savings & 704 & 189 & -7 & -4 & 628 & 132 & 321 & 98 \\
\hline shade tree savings & 414 & 178 & 0 & -1 & 407 & 159 & 156 & 77 \\
\hline indirect savings & 235 & 77 & -2 & -1 & 217 & 61 & 114 & 42 \\
\hline combined savings & 1353 & 444 & -9 & -6 & 1252 & 352 & 591 & 217 \\
\hline \multicolumn{9}{|c|}{ Heating-degree-days group $<8000,>7000($ bin $\# 14)$} \\
\hline $\begin{array}{l}\text { Energy use \& demand } \\
\text { Savings }\end{array}$ & 7191 & 3135 & 285 & 69 & 11296 & 4184 & 4553 & 2248 \\
\hline reflective roof savings & 674 & 181 & -9 & -5 & 566 & 109 & 304 & 100 \\
\hline shade tree savings & 443 & 186 & 0 & -1 & 441 & 163 & 187 & 95 \\
\hline indirect savings & 235 & 77 & -2 & -2 & 211 & 57 & 118 & 47 \\
\hline
\end{tabular}




\begin{tabular}{|c|c|c|c|c|c|c|c|c|}
\hline \multirow{2}{*}{$\begin{array}{c}\text { HDD Range, } \\
\text { Basecase, and } \\
\text { Savings by Strategy }\end{array}$} & \multicolumn{4}{|c|}{ Gas Heat } & \multicolumn{2}{|c|}{ Electric Heat } & \multicolumn{2}{|c|}{$\begin{array}{l}\text { Gas \& Electric Heat } \\
\text { Peak Power }\left(W / 1000 \mathrm{ft}^{2}\right)\end{array}$} \\
\hline & Pre-1980 & $1980^{+}$ & Pre-1980 & $1980^{+}$ & Pre-1980 & $1980^{+}$ & Pre-1980 & $1980^{+}$ \\
\hline combined savings & 1352 & 444 & -11 & -8 & 1218 & 329 & 609 & 242 \\
\hline \multicolumn{9}{|c|}{ Heating-degree-days group $>8000$ (bin \#15) } \\
\hline $\begin{array}{l}\text { Energy use \& demand } \\
\text { Savings }\end{array}$ & 5619 & 2413 & 435 & 148 & 12410 & 4859 & 3768 & 1854 \\
\hline reflective roof savings & 567 & 143 & -9 & -6 & 438 & 48 & 295 & 94 \\
\hline shade tree savings & 427 & 162 & -2 & -3 & 402 & 109 & 213 & 99 \\
\hline indirect sav & 209 & 64 & -3 & -2 & 176 & 33 & 122 & 46 \\
\hline combined savings & 1203 & 369 & -14 & -11 & 1016 & 190 & 630 & 239 \\
\hline
\end{tabular}


Table 8b. Estimated annual basecase energy use and peak demand and savings from heat-island reduction measures for retail store buildings, ordered by ranges of cooling-degree-days. Direct savings include the effect of roof reflectivity and shading by trees. The indirect savings include the effects of increasing the albedo of urban surfaces (roofs and pavements) and increasing urban vegetation. Gas Heat: Gas-heated buildings; Electric Heat: Electrically heated buildings.

\begin{tabular}{|c|c|c|c|c|c|c|c|c|}
\hline \multirow{3}{*}{\begin{tabular}{|c|} 
CDD Range, \\
Basecase, and \\
Savings by Strategy
\end{tabular}} & \multirow{2}{*}{\multicolumn{4}{|c|}{$\begin{array}{c}\text { Gas Heat } \\
\text { Electricity }\left.\left(\mathrm{kWh} / 1000 \mathrm{ft}^{2}\right)\right|_{\text {Gas }}\left(\mathrm{Therm} / 1000 \mathrm{ft}^{2}\right.\end{array}$}} & \multirow{2}{*}{\multicolumn{2}{|c|}{$\begin{array}{c}\text { Electric Heat } \\
\text { Electricity }\left(\mathrm{kWh} / 1000 \mathrm{ft}^{2}\right)\end{array}$}} & \multicolumn{2}{|c|}{ Gas \& Electric Heat } \\
\hline & & & & $\left.1000 \mathrm{ft}^{2}\right)$ & & & Peak Power & $\left.\mathrm{V} / 1000 \mathrm{ft}^{2}\right)$ \\
\hline & Pre-1980 & $1980^{+}$ & Pre-1980 & $1980^{+}$ & Pre-1980 & $1980^{+}$ & Pre-1980 & $\mid 1980^{+}$ \\
\hline \multicolumn{9}{|c|}{ Cooling-degree-days group > $5000($ bin \#1) } \\
\hline $\begin{array}{l}\text { Energy use \& demand } \\
\text { Savings }\end{array}$ & 17209 & 8919 & 0 & 0 & 17209 & 8919 & 4642 & 2454 \\
\hline reflective roof savings & 1016 & 349 & 0 & 0 & 1016 & 349 & 329 & 111 \\
\hline shade tree savings & 372 & 272 & 0 & 0 & 372 & 272 & 112 & 113 \\
\hline indirect savings & 291 & 130 & 0 & 0 & 291 & 130 & 106 & 54 \\
\hline combined savings & 1679 & 751 & 0 & 0 & 1679 & 751 & 547 & 278 \\
\hline \multicolumn{9}{|c|}{ Cooling-degree-days group $>4500,<5000$ (bin \#2) } \\
\hline $\begin{array}{l}\text { Energy use \& demand } \\
\text { Savings }\end{array}$ & 16490 & 8338 & 1 & 0 & 16496 & 8338 & 5046 & 2589 \\
\hline reflective roof savings & 955 & 331 & 0 & 0 & 955 & 331 & 305 & 112 \\
\hline shade tree savings & 473 & 148 & 0 & 0 & 474 & 148 & 362 & 42 \\
\hline indirect savings & 300 & 101 & 0 & 0 & 300 & 101 & 160 & 37 \\
\hline combined savings & 1728 & 580 & 0 & 0 & 1729 & 580 & 827 & 191 \\
\hline \multicolumn{9}{|c|}{ Cooling-degree-days group $>4000,<4500$ (bin \#3) } \\
\hline $\begin{array}{l}\text { Energy use \& demand } \\
\text { Savings }\end{array}$ & 15645 & 7900 & 0 & 0 & 15651 & 7900 & 4613 & 2314 \\
\hline reflective roof savings & 878 & 279 & 0 & 0 & 877 & 279 & 240 & 59 \\
\hline shade tree savings & 271 & 161 & 0 & 0 & 272 & 161 & -3 & 3 \\
\hline indirect savings & 241 & 92 & 0 & 0 & 241 & 92 & 57 & 15 \\
\hline combined savings & 1390 & 532 & 0 & 0 & 1390 & 532 & 294 & 77 \\
\hline \multicolumn{9}{|c|}{ Cooling-degree-days group $>3500,<4000($ bin \#4) } \\
\hline $\begin{array}{l}\text { Energy use \& demand } \\
\text { Savings }\end{array}$ & 15494 & 7665 & 6 & 0 & 15559 & $\mid 7666$ & 5106 & 2600 \\
\hline reflective roof savings & 880 & 297 & 0 & 0 & 878 & 297 & 259 & 97 \\
\hline shade tree savings & 349 & 179 & 0 & 0 & 350 & 179 & 105 & 56 \\
\hline indirect savings & 258 & 100 & 0 & 0 & 258 & 100 & 87 & 37 \\
\hline combined savings & 1487 & 576 & 0 & 0 & 1486 & 576 & 451 & 190 \\
\hline \multicolumn{9}{|c|}{ Cooling-degree-days group $>3000,<3500($ bin \#5) } \\
\hline $\begin{array}{l}\text { Energy use \& demand } \\
\text { Savings }\end{array}$ & 14639 & 6971 & 15 & 0 & 14797 & 6978 & 5373 & 2709 \\
\hline reflective roof savings & 932 & 288 & 0 & 0 & 926 & 289 & 303 & 100 \\
\hline shade tree savings & 321 & 211 & 0 & 0 & 319 & 211 & 72 & 96 \\
\hline indirect savings & 263 & 105 & 0 & 0 & 261 & 105 & 90 & 47 \\
\hline combined savings & 1516 & 604 & 0 & 0 & 1506 & 605 & 465 & 243 \\
\hline \multicolumn{9}{|c|}{ Cooling-degree-days group $>2500,<3000($ bin \#6) } \\
\hline $\begin{array}{l}\text { Energy use \& demand } \\
\text { Savings }\end{array}$ & 13695 & 6305 & 28 & 0 & 14016 & 6314 & 5445 & 2706 \\
\hline reflective roof savings & 983 & 288 & -1 & 0 & 970 & 288 & 369 & 106 \\
\hline shade tree savings & 364 & 189 & 0 & 0 & 364 & 189 & 126 & 69 \\
\hline indirect savings & 283 & 100 & 0 & 0 & 280 & 100 & 119 & 42 \\
\hline combined savings & 1630 & 577 & -1 & 0 & 1614 & 577 & 614 & 217 \\
\hline
\end{tabular}




\begin{tabular}{|c|c|c|c|c|c|c|c|c|}
\hline \multirow{2}{*}{$\begin{array}{c}\text { CDD Range, } \\
\text { Basecase, and } \\
\text { Savings by Strategy }\end{array}$} & \multicolumn{4}{|c|}{$\begin{array}{r}\text { Gas Heat } \\
\text { Electricity }\left(\mathrm{kWh} / 1000 \mathrm{ft}^{2}\right)\end{array}$} & \multicolumn{2}{|c|}{$\begin{array}{c}\text { Electric Heat } \\
\text { Electricity }\left(\mathrm{kWh} / 1000 \mathrm{ft}^{2}\right)\end{array}$} & \multicolumn{2}{|c|}{$\begin{array}{c}\text { Gas \& Electric Heat } \\
\text { Peak Power }\left(W / 1000 \mathrm{ft}^{2}\right)\end{array}$} \\
\hline & Pre-1980 & $1980^{+}$ & Pre-1980 & $1980^{+}$ & Pre-1980 & $1980^{+}$ & Pre-1980 & $1980^{+}$ \\
\hline $\begin{array}{l}\text { Energy use \& demand } \\
\text { Savings }\end{array}$ & 12724 & 5696 & 46 & 1 & 13277 & 5721 & 5485 & 2693 \\
\hline reflective roof savings & 989 & 283 & -2 & 0 & 965 & 281 & 365 & 120 \\
\hline shade tree savings & 380 & 176 & 0 & 0 & 378 & 176 & 137 & 60 \\
\hline indirect savings & 287 & 96 & -1 & 0 & 282 & 96 & 120 & 43 \\
\hline combined savings & 1656 & 555 & -3 & 0 & 1625 & 553 & 622 & 223 \\
\hline \multicolumn{9}{|c|}{ Cooling-degree-days group $>1500,<2000($ bin $\# 8)$} \\
\hline $\begin{array}{l}\text { Energy use \& demand } \\
\text { Savings }\end{array}$ & 11390 & 5028 & 82 & 6 & 12439 & 5128 & 5388 & 2659 \\
\hline reflective roof savings & 919 & 253 & -4 & 0 & 872 & 244 & 342 & 105 \\
\hline shade tree savings & 348 & 167 & 0 & 0 & 344 & 166 & 102 & 35 \\
\hline indirect savings & 266 & 88 & -1 & 0 & 255 & 86 & 107 & 34 \\
\hline combined savings & 1533 & 508 & -5 & 0 & 1471 & 496 & 551 & 174 \\
\hline \multicolumn{9}{|c|}{ Cooling-degree-days group $>1000,<1500($ bin $\# 9)$} \\
\hline $\begin{array}{l}\text { Energy use \& demand } \\
\text { Savings }\end{array}$ & 9687 & 4264 & 150 & 21 & 11690 & 4573 & 5106 & 2530 \\
\hline reflective roof savings & 825 & 225 & -6 & -2 & 758 & 198 & 337 & 117 \\
\hline shade tree savings & 394 & 182 & 0 & 0 & 397 & 176 & 146 & 80 \\
\hline indirect savings & 256 & 85 & -2 & -1 & 243 & 79 & 116 & 47 \\
\hline combined savings & 1475 & 492 & -8 & -3 & 1398 & 453 & 599 & 244 \\
\hline \multicolumn{9}{|c|}{ Cooling-degree-days group $>500,<1000($ bin \#10) } \\
\hline $\begin{array}{l}\text { Energy use \& demand } \\
\text { Savings }\end{array}$ & 8192 & 3601 & 247 & 59 & 11716 & 4500 & 4861 & 2401 \\
\hline reflective roof savings & 719 & 195 & -7 & -4 & 641 & 138 & 319 & 101 \\
\hline shade tree savings & 416 & 181 & 0 & -1 & 411 & 163 & 162 & 80 \\
\hline indirect savings & 238 & 79 & -2 & -1 & 221 & 63 & 115 & 43 \\
\hline combined savings & 1373 & 455 & -9 & -6 & 1273 & 364 & 596 & 224 \\
\hline \multicolumn{9}{|c|}{ Cooling-degree-days group $>200,<500($ bin \#11) } \\
\hline $\begin{array}{l}\text { Energy use \& demand } \\
\text { Savings }\end{array}$ & 7184 & 3090 & 272 & 66 & 11121 & 4116 & 4421 & 2172 \\
\hline reflective roof savings & 703 & 187 & -8 & -4 & 599 & 119 & 319 & 100 \\
\hline shade tree savings & 469 & 191 & 0 & -1 & 468 & 167 & 201 & 95 \\
\hline indirect savings & 246 & 79 & -2 & -1 & 224 & 60 & 125 & 47 \\
\hline combined savings & 1418 & 457 & -10 & -6 & 1291 & 346 & 645 & 242 \\
\hline \multicolumn{9}{|c|}{ Cooling-degree-days group < 200 (bin \#12) } \\
\hline $\begin{array}{l}\text { Energy use \& demand } \\
\text { Savings }\end{array}$ & 5613 & 2177 & 345 & $\mid 109$ & 10850 & 3975 & 3463 & 1697 \\
\hline reflective roof savings & 631 & 146 & -7 & -4 & 531 & 83 & 306 & 104 \\
\hline shade tree savings & 457 & 160 & -1 & -2 & 432 & 117 & 222 & 111 \\
\hline indirect savings & 228 & 64 & -2 & -2 & 202 & 42 & 127 & 52 \\
\hline combined savings & 1316 & 370 & -10 & -8 & 1165 & 242 & 655 & 267 \\
\hline
\end{tabular}


Table 8c. Estimated annual basecase carbon emissions and savings from heat-island reduction measures for retail store buildings, ordered by ranges of heating-degree-days. Direct savings include the effect of roof reflectivity and shading by trees. The indirect savings include the effects of increasing the albedo of urban surfaces (roofs and pavements) and increasing urban vegetation. Gas Heat: Gas-heated buildings; Electric Heat: Electrically heated buildings.

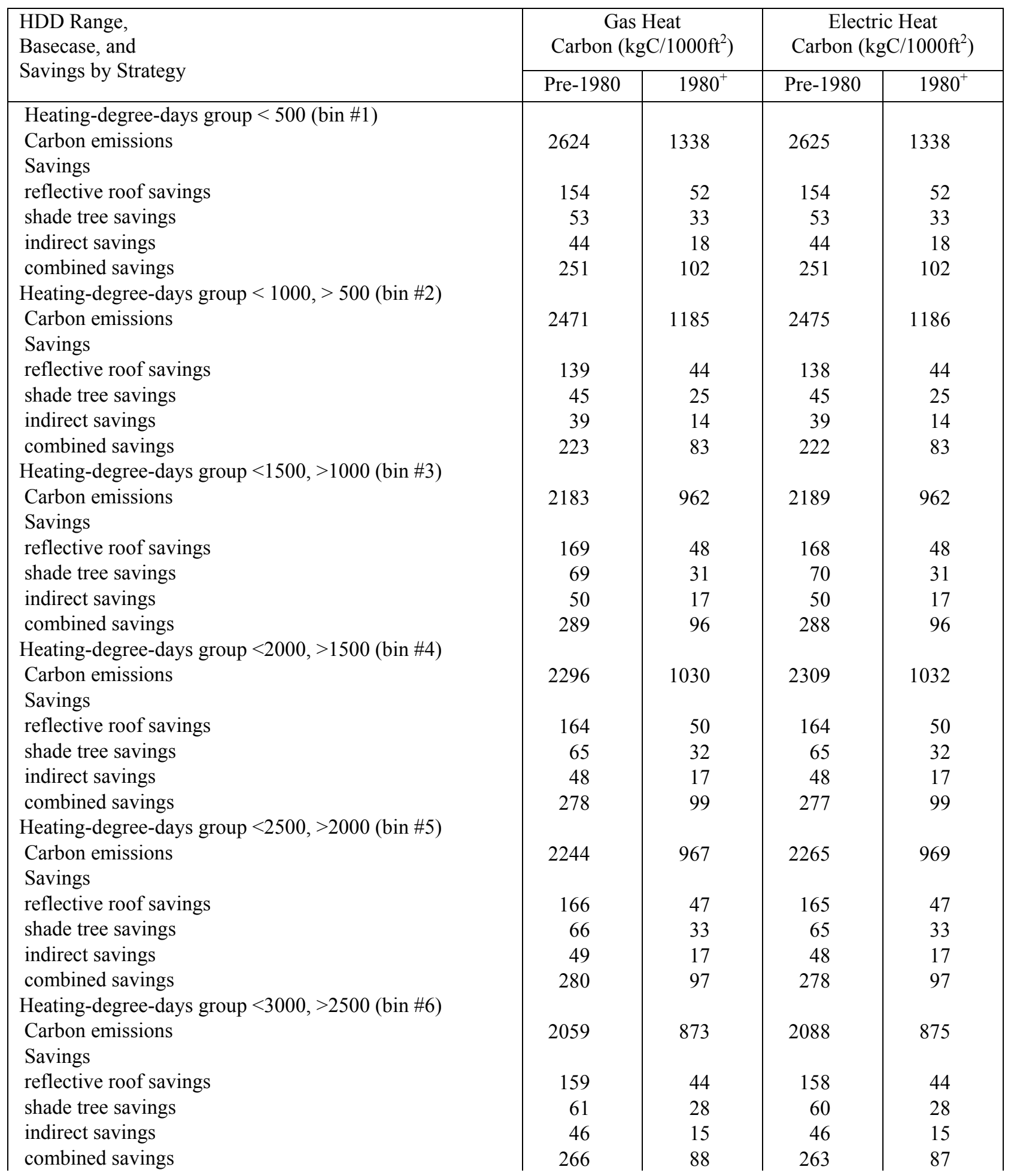




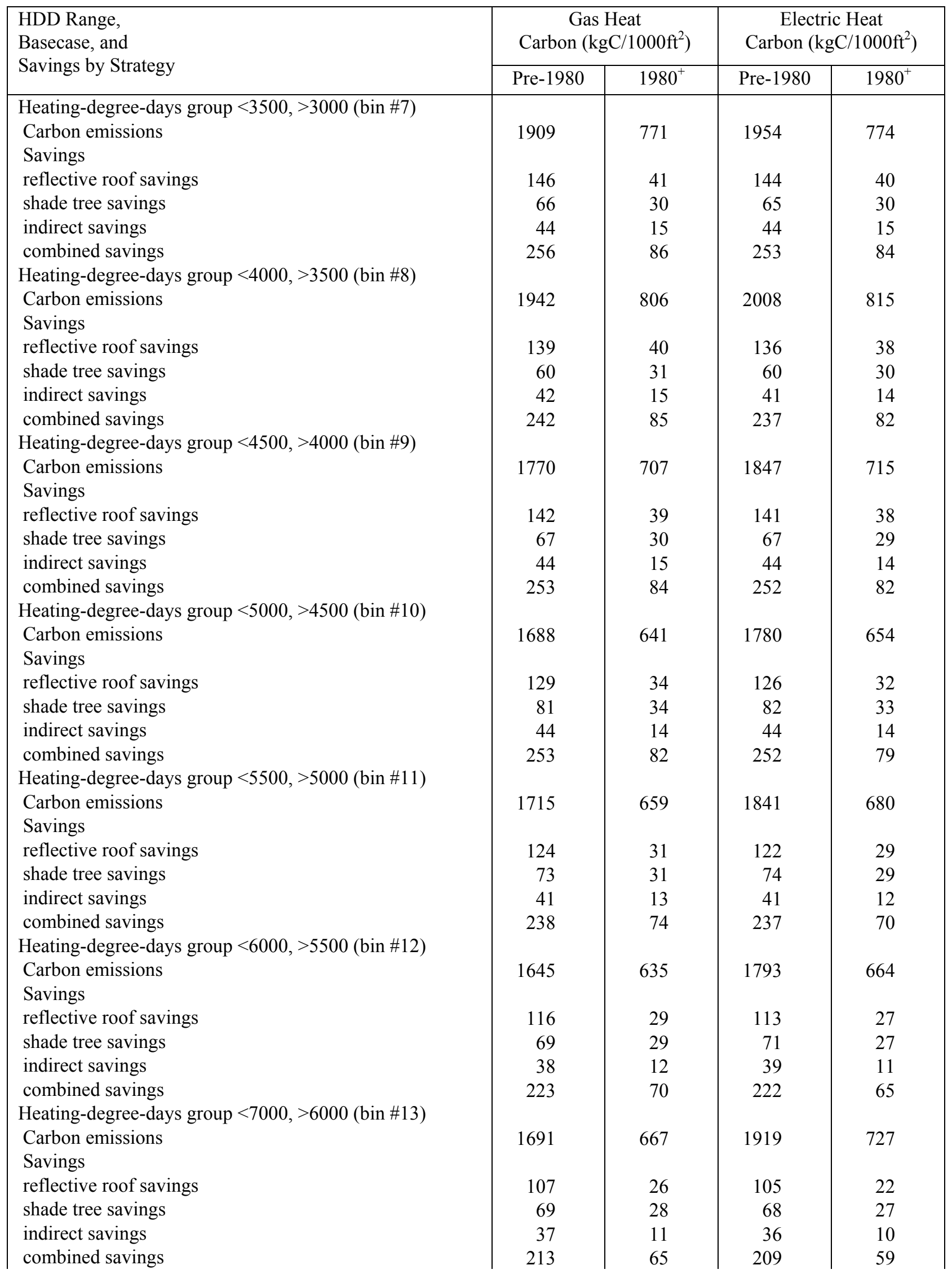




\begin{tabular}{|l|c|c|c|c|}
\hline HDD Range, & \multicolumn{2}{|c|}{$\begin{array}{c}\text { Gas Heat } \\
\text { Carbon }\left(\mathrm{kgC} / 1000 \mathrm{ft}^{2}\right)\end{array}$} & \multicolumn{2}{c|}{ Electric Heat } \\
Carbon $\left(\mathrm{kgC} / 1000 \mathrm{ft}^{2}\right)$
\end{tabular}


Table 8d. Estimated annual basecase carbon emissions and savings from heat-island reduction measures for retail store buildings, ordered by ranges of cooling-degree-days. Direct savings include the effect of roof reflectivity and shading by trees. The indirect savings include the effects of increasing the albedo of urban surfaces (roofs and pavements) and increasing urban vegetation. Gas Heat: Gas-heated buildings; Electric Heat: Electrically heated buildings.

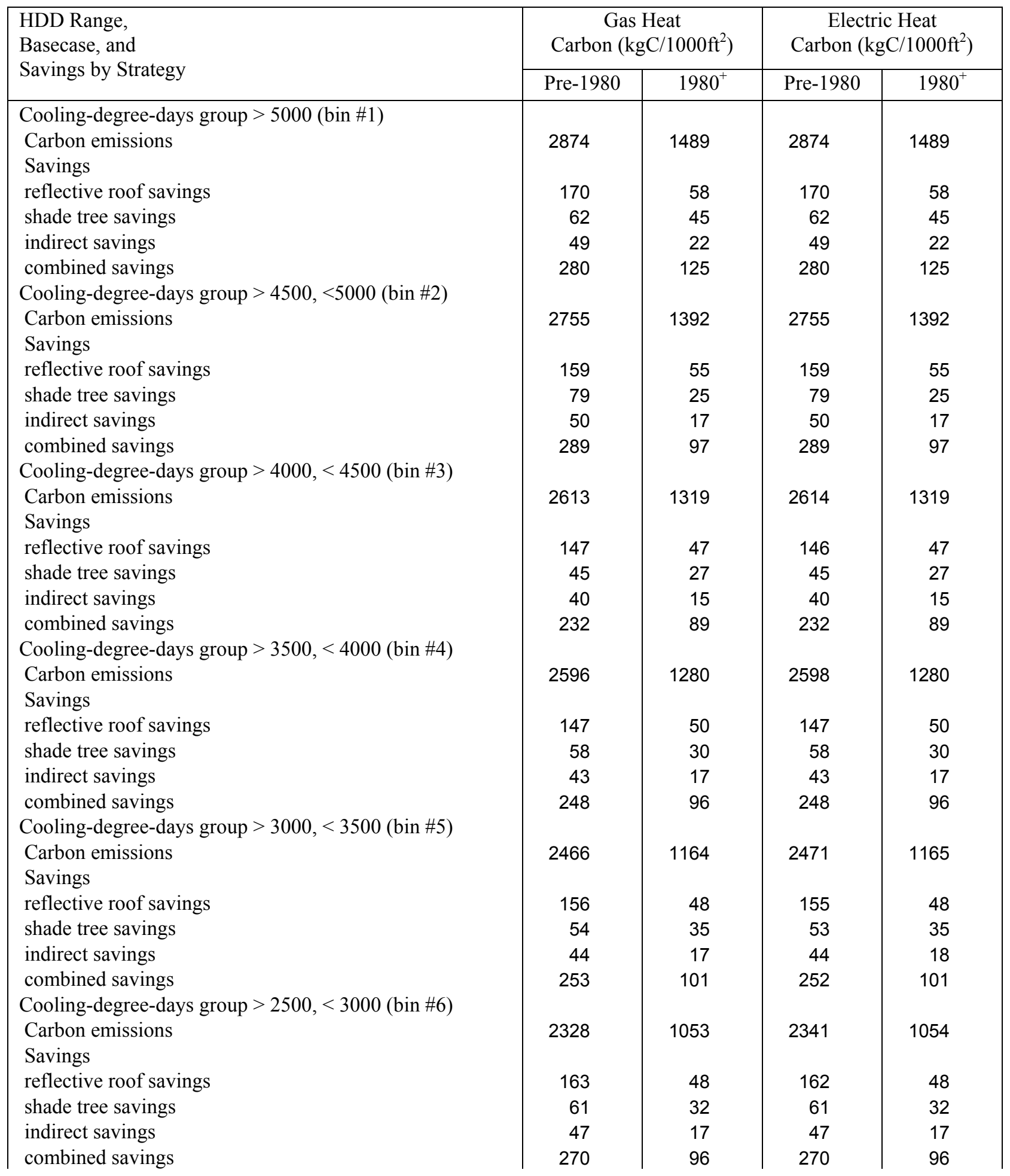




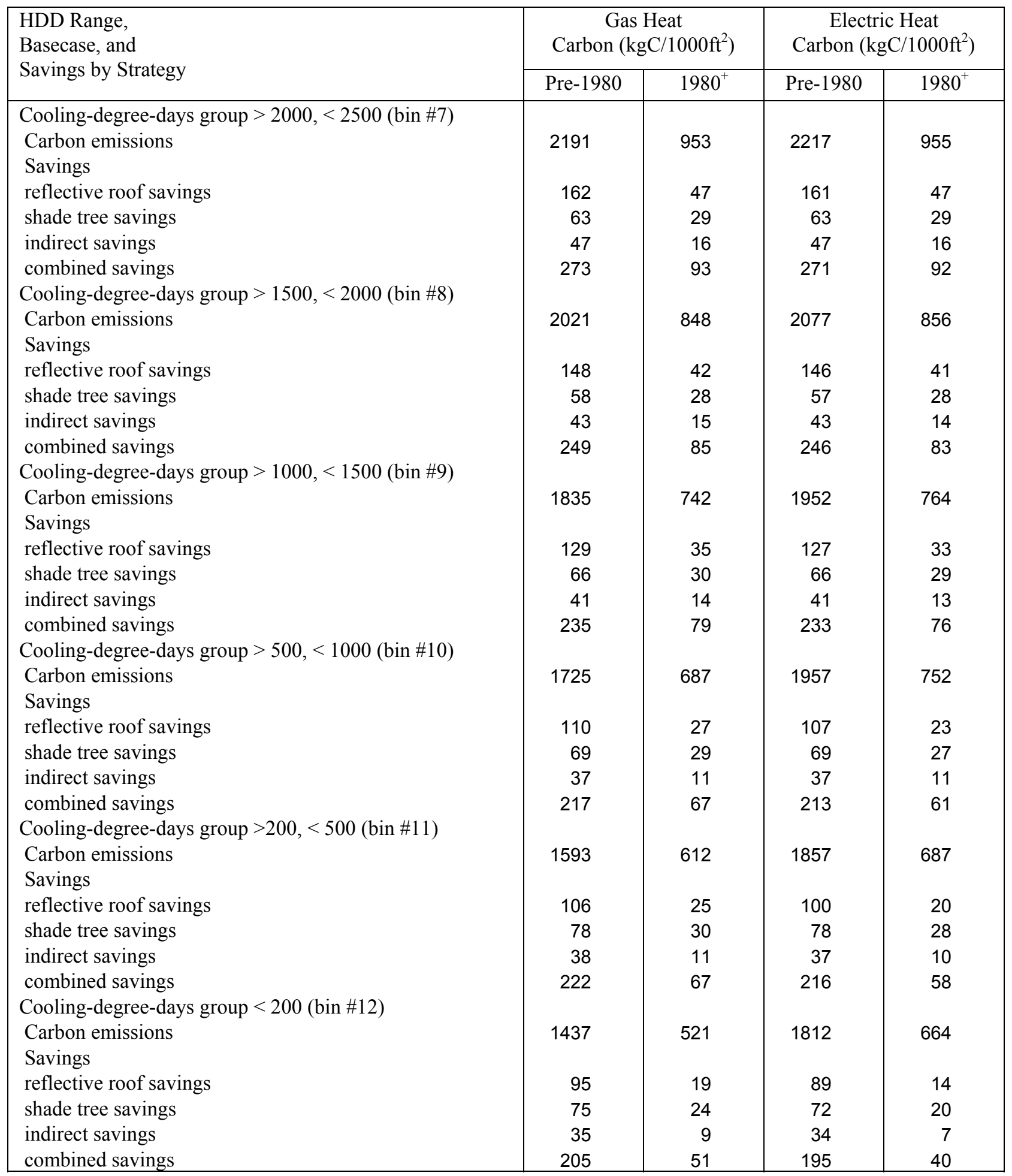


We also calculated the total carbon emissions from heating and cooling the buildings (Tables 6c, 6d, 7c, 7d, 8c, and 8d). To generate these tables we used data provided by DOE's office of Energy Information Administration (EIA, 1997). [The corresponding conversion factor for 2001 is $0.173 \mathrm{kgC} / \mathrm{kWh}$ (EIA, 2003)]. In 1995, the U.S. mix of electricity generation emitted $0.167 \mathrm{kgC} / \mathrm{kWh}$. The estimated carbon emission from combustion of natural gas was 1.447 $\mathrm{kgC} /$ therm.

To estimate direct savings from increased roof reflectance $(\Delta \rho)$ other than the differential specified in the tables, multiply the savings by the ratio $\Delta \rho / 0.3$ for residences and $\Delta \rho / 0.4$ for commercial buildings ${ }^{1}$. Linear interpolation can also be applied to direct shade-tree savings. Savings will increase for buildings with less roof insulation than that specified in these prototypes (R-11 for old construction; R-30 for new). Conversely, savings will decrease for those with more roof insulation. Savings in peak power demand make it clear that an airconditioner can be downsized when HIR strategies are considered.

Snow cover will negate some of the heating-energy penalties from a reflective roof depending on what fraction of the roof is covered and for what duration. To account for snow cover in the annual natural gas deficit (heating penalties) a reduction of $50 \%$ for the reflective roof and $25 \%$ in the indirect effect can be assumed.

The estimated savings may be questionable for cases where the HDD is very high (over 6000 ) or CDD is very low (under 200). In very cold climates, the energy-savings potentials of HIR are expected to be minimal.

Residential Buildings by Heating-Degree-Days. (Tables 6a and 6c) (All numbers are normalized per $1000 \mathrm{ft}^{2}$ of roof area). For stock of Pre-1980 gas-heated residential buildings, the annual basecase electricity use ranges from about $8500 \mathrm{kWh}$ (for HDD<500) to $2000 \mathrm{kWh}$ (for $5500<\mathrm{HDD}<6000)$. The total HIR savings potentials range from about $1200 \mathrm{kWh}(15 \%)$ $(\mathrm{HDD}<500)$ to about $500 \mathrm{kWh}(25 \%)(5500<\mathrm{HDD}<6000)$. The heating-energy use ranges from 0 to 900 therms and penalties range from 0 to 45 therms $(0-5 \%)$. For $1980^{+}$stock of residential buildings, the annual basecase electricity use ranges from about $5000 \mathrm{kWh}$ (for $\mathrm{HDD}<500$ ) to $1000 \mathrm{kWh}$ (for $5500<\mathrm{HDD}<6000$ ). The total HIR savings potentials range from about $600 \mathrm{kWh}$ $(12 \%)(\mathrm{HDD}<500)$ to about $200 \mathrm{kWh}(20 \%)(5500<\mathrm{HDD}<6000)$. The heating-energy use ranges from 0 to 400 therms and penalties range from 0 to 20 therms $(0-5 \%)$. These results are summarized in Table 9.

For stock of Pre-1980 electrically heated residential buildings, the annual basecase electricity use (heating and cooling) ranges from about $8500 \mathrm{kWh}($ for $\mathrm{HDD}<500$ ) to 15,000 $\mathrm{kWh}$ (for $5500<\mathrm{HDD}<6000$ ). The total HIR savings potentials range from about $1200 \mathrm{kWh}$ $(15 \%)(\mathrm{HDD}<500)$ to about $100 \mathrm{kWh}(0 \%)(5500<\mathrm{HDD}<6000)$. For $1980^{+}$stock of residential buildings, the annual basecase electricity use ranges from about $5000 \mathrm{kWh}$ (for $\mathrm{HDD}<500$ ) to $6500 \mathrm{kWh}$ (for $5500<\mathrm{HDD}<6000$ ). The total HIR savings potentials range from about $600 \mathrm{kWh}$

${ }^{1}$ Linear interpolation can be used to estimate savings or penalties for other net changes in roof reflectance $\left(\Delta \rho_{2}\right)$ than presented in the tables $\left(\Delta \rho_{1}\right)$ (Konopacki et al. 1997). Therefore, these results can be simply adjusted by the ratio $\Delta \rho_{2} / \Delta \rho_{1}$ to obtain estimates for other reflective roof scenarios. 
$(12 \%)(\mathrm{HDD}<500)$ to about $50 \mathrm{kWh}(1 \%)(5500<\mathrm{HDD}<6000)$. Over $75 \%$ of the total savings are from direct effects of cool roofs and shade trees.

The peak demand electricity use is about 3.1 to $4.0 \mathrm{~kW} / 1000 \mathrm{ft}^{2}$ of roof area for Pre-1980 residential stock and $1.7-3.3 \mathrm{~kW} / 1000 \mathrm{ft}^{2}$ for $1980^{+}$stock. The total savings range from $0.4-0.6$ $\mathrm{kW} / 1000 \mathrm{ft}^{2}$ for Pre-1980 stock and $0.2-0.4 \mathrm{~kW} / 1000 \mathrm{ft}^{2}$ for $1980^{+}$stock.

For stock of Pre-1980 gas-heated residential buildings, the annual rate of carbon emissions ranges from 1100-2600 kgC. The total carbon savings for climates with less than 4500 heating-degree-days ranged from $60-210 \mathrm{kgC}$. For $1980^{+}$stock of gas-heated residential buildings, the annual rate of carbon emissions ranges from $400-1200 \mathrm{kgC}$. The total carbon savings for climates with less than 4500 heating-degree-days ranged from $30-100 \mathrm{kgC}$. For stock of Pre-1980 electrically heated residential buildings, the annual rate of carbon emissions ranges from $900-4800 \mathrm{kgC}$. The total carbon savings for climates with less than 4500 heating-degreedays range from $60-210 \mathrm{kgC}$. For $1980^{+}$stock of electrically heated residential buildings, the annual rate of carbon emissions ranges from $430-2300 \mathrm{kgC}$. The total carbon savings for climates with less than 4500 heating-degree-days range from 30-100 $\mathrm{kgC}$.

Residential Buildings by Cooling-degree-days. (Table 6b and 6d) (All numbers are normalized per $1000 \mathrm{ft}^{2}$ of roof area). For stock of Pre-1980 gas-heated residential buildings, the annual basecase electricity use ranges from about $11,000 \mathrm{kWh}$ (for CDD>5000) to $1600 \mathrm{kWh}$ (for $200<\mathrm{CDD}<500$ ). The total HIR savings potential range from about $1200 \mathrm{kWh}(10 \%)$ $(\mathrm{CDD}>5000)$ to about $400 \mathrm{kWh}(25 \%)(200<\mathrm{CDD}<500)$. The heating-energy use ranges from 0 to 1000 therms and penalties range from 0 to 50 therms $(0-5 \%)$. For $1980^{+}$stock of residential buildings, the annual basecase electricity use ranges from about $7000 \mathrm{kWh}$ (for CDD $>5000$ ) to $700 \mathrm{kWh}$ (for $200<\mathrm{CDD}<500$ ). The total HIR savings potentials for range from about $600 \mathrm{kWh}$ $(8 \%)(\mathrm{CDD}>5000)$ to about $150 \mathrm{kWh}(20 \%)(200<\mathrm{CDD}<500)$. The heating-energy use ranges from 0 to 500 therms and penalties range from 0 to 20 therms $(0-4 \%)$. These results are summarized in Table 9.

For stock of Pre-1980 electrically heated residential buildings, the annual basecase electricity use (heating and cooling) ranges from about $11,000 \mathrm{kWh}$ (for CDD $>5000$ ) to 20,000 $\mathrm{kWh}$ (for $200<\mathrm{CDD}<500)$. The total HIR savings potentials range from about $1300 \mathrm{kWh}(15 \%)$ $(\mathrm{HDD}<500)$ to about $-250 \mathrm{kWh}(-1 \%)(200<\mathrm{CDD}<500)$. For $1980^{+}$stock of residential buildings, the annual basecase electricity use ranges from about $700 \mathrm{kWh}$ (for CDD $>5000$ ) to $9000 \mathrm{kWh}$ (for $200<\mathrm{CDD}<500$ ). The total HIR savings potentials range from about $600 \mathrm{kWh}$ $(8 \%)(\mathrm{CDD}>5000)$ to about $-50 \mathrm{kWh}(-1 \%)(200<\mathrm{CDD}<500)$. Over $75 \%$ of the total savings are from direct effects of cool roofs and shade trees.

The peak demand electricity use is about 3.2 to $4.0 \mathrm{~kW} / 1000 \mathrm{ft}^{2}$ of roof area for Pre-1980 residential stock and $1.7-2.2 \mathrm{~kW} / 1000 \mathrm{ft}^{2}$ for $1980^{+}$stock. The total savings range from $0.4-0.6$ $\mathrm{kW} / 1000 \mathrm{ft}^{2}$ for Pre-1980 stock and 0.2-0.4 kW/1000 $\mathrm{ft}^{2}$ for $1980^{+}$stock.

For stock of Pre-1980 gas-heated residential buildings, the annual rate of carbon emissions ranges from $1100-2200 \mathrm{kgC}$. The total carbon savings for climates with more than 1000 cooling-degree-days range from $60-220 \mathrm{kgC}$. For $1980^{+}$stock of gas-heated residential buildings, the annual rate of carbon emissions ranges from $560-1040 \mathrm{kgC}$. The total carbon savings for climates with less than 4500 heating-degree-days range from 30-100 kgC. For stock of Pre-1980 electrically heated residential buildings, the annual rate of carbon emissions ranges from $1300-4000 \mathrm{kgC}$. The total carbon savings for climates with less than 4500 heating-degree- 
days range from $60-220 \mathrm{kgC}$. For $1980^{+}$stock of electrically heated residential buildings, the annual rate of carbon emissions ranges from $630-1800 \mathrm{kgC}$. The total carbon savings for climates with less than 4500 heating-degree-days ranged from 30-100 kgC.

Office Buildings by Heating-degree-days. (Table 7a and 7c) (All numbers are normalized per $1000 \mathrm{ft}^{2}$ of roof area). For stock of Pre-1980 gas-heated office buildings, the annual basecase electricity use ranges from about $16,800 \mathrm{kWh}$ (for $\mathrm{HDD}<500$ ) to $8,000 \mathrm{kWh}$ (for $5500<\mathrm{HDD}<6000)$. The total HIR savings potentials range from about $1200 \mathrm{kWh}(7 \%)$ $(\mathrm{HDD}<500)$ to about $1,400 \mathrm{kWh}(18 \%)(5500<\mathrm{HDD}<6000)$. The heating energy use ranges from 0 to 300 therms and penalties range from 0 to 15 therms $(0-5 \%)$. For $1980^{+}$stock of office buildings, the annual basecase electricity use ranges from about $9600 \mathrm{kWh}$ (for $\mathrm{HDD}<500$ ) to $4000 \mathrm{kWh}$ (for $5500<\mathrm{HDD}<6000$ ). The total HIR savings potentials range from about $500 \mathrm{kWh}$ $(5 \%)(\mathrm{HDD}<500)$ to about $500 \mathrm{kWh}(12 \%)(5500<\mathrm{HDD}<6000)$. The heating-energy use ranges from 0 to 140 therms and penalties range from 0 to 10 therms $(0-7 \%)$. These results are summarized in Table 9.

For stock of Pre-1980 electrically heated office buildings, the annual basecase electricity use (heating and cooling) ranges from about 16,900 kWh (for $\mathrm{HDD}<500$ ) to $12,600 \mathrm{kWh}$ (for $5500<\mathrm{HDD}<6000)$. The total HIR savings potentials range from about $1200 \mathrm{kWh}(7 \%)$ $(\mathrm{HDD}<500)$ to about $1200 \mathrm{kWh}(10 \%)(5500<\mathrm{HDD}<6000)$. For $1980^{+}$stock of office buildings, the annual basecase electricity use ranges from about $9600 \mathrm{kWh}$ (for $\mathrm{HDD}<500$ ) to $5700 \mathrm{kWh}$ (for $5500<\mathrm{HDD}<6000$ ). The total HIR savings potentials range from about $500 \mathrm{kWh}(5 \%)$ $(\mathrm{HDD}<500)$ to about $400 \mathrm{kWh}(7 \%)(5500<\mathrm{HDD}<6000)$. Over $75 \%$ of the total savings are from direct effects of cool roofs and shade trees.

The peak demand electricity use is about 6.7 to $8.4 \mathrm{~kW} / 1000 \mathrm{ft}^{2}$ of roof area for Pre-1980 office stock and $3.7-4.6 \mathrm{~kW} / 1000 \mathrm{ft}^{2}$ for $1980^{+}$stock. The total savings range from $0.5-1.0$ $\mathrm{kW} / 1000 \mathrm{ft}^{2}$ for Pre-1980 stock and $0.2-0.4 \mathrm{~kW} / 1000 \mathrm{ft}^{2}$ for $1980^{+}$stock.

For stock of Pre-1980 gas-heated office buildings, the annual rate of carbon emissions ranges from 1800-2800 kgC. The total carbon savings for climates with less than 8000 heatingdegree-days range from $200-260 \mathrm{kgC}$. For $1980^{+}$stock of gas-heated residential buildings, the annual rate of carbon emissions ranges from $800-1600 \mathrm{kgC}$. The total carbon savings for climates with less than 8000 heating-degree-days range from 70-90 kgC. For stock of Pre-1980 electrically heated residential buildings, the annual rate of carbon emissions ranges from 2000$2800 \mathrm{kgC}$. The total carbon savings for climates with less than 8000 heating-degree-days range from $200-260 \mathrm{kgC}$. For $1980^{+}$stock of electrically heated residential buildings, the annual rate of carbon emissions ranges from $900-1600 \mathrm{kgC}$. The total carbon savings for climates with less than 4500 heating-degree-days ranged from 50-100 $\mathrm{kgC}$.

Office Buildings by Cooling-degree-days. (Table $7 \mathbf{b}$ and 7d) (All numbers are normalized per $1000 \mathrm{ft}^{2}$ of roof area). For stock of Pre-1980 gas-heated office buildings, the annual basecase electricity use ranges from about $18,700 \mathrm{kWh}$ (for CDD>5000) to 7,000 kWh (for $200<\mathrm{CDD}<500)$. The total HIR savings potentials range from about $1300 \mathrm{kWh}(7 \%)$ $(\mathrm{CDD}>5000)$ to about $1400 \mathrm{kWh}(20 \%)(200<\mathrm{CDD}<500)$. The heating energy use ranges from 0 to 500 therms and penalties range from 0 to 20 therms $(0-4 \%)$. For $1980^{+}$stock of office buildings, the annual basecase electricity use ranges from about 10,800 kWh (for CDD $>5000$ ) to $3,500 \mathrm{kWh}$ (for $200<\mathrm{CDD}<500$ ). The total HIR savings potentials range from about $600 \mathrm{kWh}$ $(5 \%)(\mathrm{CDD}>5000)$ to about $500 \mathrm{kWh}(14 \%)(200<\mathrm{CDD}<500)$. The heating energy use ranges 
from 0 to 300 therms and penalties range from 0 to 10 therms $(0-3 \%)$. These results are summarized in Table 9.

For stock of Pre-1980 electrically heated office buildings, the annual basecase electricity use (heating and cooling) ranges from about 18,700 kWh (for CDD $>5000$ ) to $13,800 \mathrm{kWh}$ (for $200<\mathrm{CDD}<500)$. The total HIR savings potentials range from about $1300 \mathrm{kWh}(7 \%)$ $(\mathrm{HDD}<500)$ to about $1100 \mathrm{kWh}(8 \%)(200<\mathrm{CDD}<500)$. For $1980^{+}$stock of office buildings, the annual basecase electricity use ranges from about 10,800 kWh (for CDD $>5000$ ) to $6,400 \mathrm{kWh}$ (for $200<\mathrm{CDD}<500$ ). The total HIR savings potentials range from about $600 \mathrm{kWh}(5 \%)$ $(\mathrm{CDD}>5000)$ to about $300 \mathrm{kWh}(5 \%)(200<\mathrm{CDD}<500)$. Over $75 \%$ of the total savings are from direct effects of cool roofs and shade trees.

The peak demand electricity use is about 6.3 to $8.0 \mathrm{~kW} / 1000 \mathrm{ft}^{2}$ of roof area for Pre-1980 office stock and $3.5-4.4 \mathrm{~kW} / 1000 \mathrm{ft}^{2}$ for $1980^{+}$stock. The total savings range from $0.5-1.0$ $\mathrm{kW} / 1000 \mathrm{ft}^{2}$ for Pre-1980 stock and $0.2-0.5 \mathrm{~kW} / 1000 \mathrm{ft}^{2}$ for $1980^{+}$stock.

For stock of Pre-1980 gas-heated office buildings, the annual rate of carbon emissions ranges from 1900-3100 $\mathrm{kgC}$. The total carbon savings for climates with more than 200 coolingdegree-days range from $210-250 \mathrm{kgC}$. For $1980^{+}$stock of gas-heated residential buildings, the annual rate of carbon emissions ranges from $830-1800 \mathrm{kgC}$. The total carbon savings for climates with more than 200 cooling-degree-days ranges from $70-120 \mathrm{kgC}$. For stock of Pre1980 electrically heated residential buildings, the annual rate of carbon emissions ranges from 2200-3100 kgC. The total carbon savings for climates with more than 200 cooling-degree-days range from 190-240 $\mathrm{kgC}$. For $1980^{+}$stock of electrically heated residential buildings, the annual rate of carbon emissions ranges from $1100-1800 \mathrm{kgC}$. The total carbon savings for climates with more than 200 heating-degree-days ranges from $50-100 \mathrm{kgC}$.

Retail Store Buildings by Heating-degree-days. (Table 8a) (All numbers are normalized per $1000 \mathrm{ft}^{2}$ of roof area). For stock of Pre-1980 gas-heated retail store buildings, the annual basecase electricity use ranges from about $15,700 \mathrm{kWh}$ (for $\mathrm{HDD}<500$ ) to $8,200 \mathrm{kWh}$ (for $5500<\mathrm{HDD}<6000)$. The total HIR savings potentials range from about $1,500 \mathrm{kWh}(10 \%)$ $(\mathrm{HDD}<500)$ to about $1,400 \mathrm{kWh}(17 \%)(5500<\mathrm{HDD}<6000)$. The heating-energy use ranges from 0 to 200 therms and penalties range from 0 to 10 therms $(0-5 \%)$. For $1980^{+}$stock of retail store buildings, the annual basecase electricity use ranges from about $8,000 \mathrm{kWh}$ (for $\mathrm{HDD}<$ 500 ) to $3,500 \mathrm{kWh}$ (for $5500<\mathrm{HDD}<6000$ ). The total HIR savings potentials range from about $600 \mathrm{kWh}(7 \%)(\mathrm{HDD}<500)$ to about $500 \mathrm{kWh}(14 \%)(5500<\mathrm{HDD}<6000)$. The heating-energy use ranges from 0 to 30 therms and penalties range from 0 to 4 therms $(0-13 \%)$. These results are summarized in Table 9.

For stock of Pre-1980 electrically heated retail store buildings, the annual basecase electricity use (heating and cooling) ranges from about $15,700 \mathrm{kWh}$ (for $\mathrm{HDD}<500$ ) to 10,700 $\mathrm{kWh}$ (for $5500<\mathrm{HDD}<6000$ ). The total HIR savings potentials range from about $1500 \mathrm{kWh}$ $(10 \%)(\mathrm{HDD}<500)$ to about $1300 \mathrm{kWh}(12 \%)(5500<\mathrm{HDD}<6000)$. For $1980^{+}$stock of retail store buildings, the annual basecase electricity use ranges from about $8,000 \mathrm{kWh}$ (for $\mathrm{HDD}<$ 500 ) to $4,000 \mathrm{kWh}$ (for $5500<\mathrm{HDD}<6000$ ). The total HIR savings potentials range from about $600 \mathrm{kWh}(7 \%)(\mathrm{HDD}<500)$ to about $400 \mathrm{kWh}(10 \%)(5500<\mathrm{HDD}<6000)$. Over $75 \%$ of the total savings are from direct effects of cool roofs and shade trees. 
The peak demand electricity use is about 4.5 to $5.7 \mathrm{~kW} / 1000 \mathrm{ft}^{2}$ of roof area for Pre-1980 retail store stock and $2.3-2.8 \mathrm{~kW} / 1000 \mathrm{ft}^{2}$ for $1980^{+}$stock. The total savings range from $0.4-0.7$ $\mathrm{kW} / 1000 \mathrm{ft}^{2}$ for Pre-1980 stock and $0.2-0.3 \mathrm{~kW} / 1000 \mathrm{ft}^{2}$ for $1980^{+}$stock.

For stock of Pre-1980 gas-heated retail store buildings, the annual rate of carbon emissions ranges from $1600-1900 \mathrm{kgC}$. The total carbon savings for climates with less than 8000 heating-degree-days range from $210-260 \mathrm{kgC}$. For $1980^{+}$stock of gas-heated residential buildings, the annual rate of carbon emissions ranges from $600-800 \mathrm{kgC}$. The total carbon savings for climates with less than 8000 heating-degree-days range from $60-90 \mathrm{kgC}$. For stock of Pre-1980 electrically heated residential buildings, the annual rate of carbon emissions ranges from 1800-2100 $\mathrm{kgC}$. The total carbon savings for climates with less than 8000 heating-degreedays range from $200-250 \mathrm{kgC}$. For $1980^{+}$stock of electrically heated residential buildings, the annual rate of carbon emissions ranges from $650-810 \mathrm{kgC}$. The total carbon savings for climates with less than 4500 heating-degree-days range from $50-800 \mathrm{kgC}$.

Retail Store Buildings by Cooling-degree-days. (Table 8b) (All numbers are normalized per $1000 \mathrm{ft}^{2}$ of roof area). For stock of Pre-1980 gas-heated retail store buildings, the annual basecase electricity use ranges from about 17,200 kWh (for CDD>5000) to 7,200 kWh (for $200<\mathrm{CDD}<500)$. The total HIR savings potentials range from about $1800 \mathrm{kWh}(10 \%)$ $(\mathrm{CDD}>5000)$ to about $1400 \mathrm{kWh}(20 \%)(200<\mathrm{CDD}<500)$. The heating-energy use ranges from 0 to 300 therms and penalties range from 0 to 10 therms $(0-3 \%)$. For $1980^{+}$stock of retail store buildings, the annual basecase electricity use ranges from about $8,900 \mathrm{kWh}$ (for CDD $>5000$ ) to $3,100 \mathrm{kWh}$ (for $200<\mathrm{CDD}<500$ ). The total HIR savings potentials range from about $700 \mathrm{kWh}$ $(8 \%)(\mathrm{CDD}>5000)$ to about $500 \mathrm{kWh}(16 \%)(200<\mathrm{CDD}<500)$. The heating-energy use ranges from 0 to 60 therms and penalties range from 0 to 6 therms $(0-10 \%)$. These results are summarized in Table 9.

For stock of Pre-1980 electrically heated retail store buildings, the annual basecase electricity use (heating and cooling) ranges from about 17,200 kWh (for CDD $>5000$ ) to 11,100 $\mathrm{kWh}$ (for $200<\mathrm{CDD}<500)$. The total HIR savings potentials range from about $1700 \mathrm{kWh}(10 \%)$ $(\mathrm{HDD}<500)$ to about $1300 \mathrm{kWh}(12 \%)(200<\mathrm{CDD}<500)$. For $1980^{+}$stock of retail store buildings, the annual basecase electricity use ranges from about $8,900 \mathrm{kWh}$ (for CDD $>5000$ ) to $4,100 \mathrm{kWh}$ (for $200<\mathrm{CDD}<500$ ). The total HIR savings potentials range from about $700 \mathrm{kWh}$ $(8 \%)(\mathrm{CDD}>5000)$ to about $300 \mathrm{kWh}(7 \%)(200<\mathrm{CDD}<500)$. Over $75 \%$ of the total savings are from direct effects of cool roofs and shade trees.

The peak demand electricity use is about 4.1 to $5.5 \mathrm{~kW} / 1000 \mathrm{ft}^{2}$ of roof area for Pre-1980 retail store stock and $2.2-2.7 \mathrm{~kW} / 1000 \mathrm{ft}^{2}$ for $1980^{+}$stock. The total savings range from $0.5-0.6$ $\mathrm{kW} / 1000 \mathrm{ft}^{2}$ for Pre-1980 stock and $0.2-0.3 \mathrm{~kW} / 1000 \mathrm{ft}^{2}$ for $1980^{+}$stock.

For stock of Pre-1980 gas-heated retail store buildings, the annual rate of carbon emissions ranges from 1400-2900 kgC. The total carbon savings for climates with more than 200 cooling-degree-days range from $220-290 \mathrm{kgC}$. For $1980^{+}$stock of gas-heated residential buildings, the annual rate of carbon emissions ranges from $520-1500 \mathrm{kgC}$. The total carbon savings for climates with more than 200 cooling-degree-days range from $70-120 \mathrm{kgC}$. For stock of Pre-1980 electrically heated residential buildings, the annual rate of carbon emissions ranges from 1800-2900 $\mathrm{kgC}$. The total carbon savings for climates with more than 200 cooling-degreedays range from $220-290 \mathrm{kgC}$. For $1980^{+}$stock of electrically heated residential buildings, the 
annual rate of carbon emissions ranges from $660-1500 \mathrm{kgC}$. The total carbon savings for climates with more than 200 heating-degree-days range from $60-120 \mathrm{kgC}$.

\section{Using Tables 6-8 to Estimate the Heat-Island Reduction Potential for a City}

The information summarized in Table 6-8 and Figures 3-5 can be used in many ways to estimate energy-saving potentials from the application of reflective roofs and shade trees.

\section{Estimating Savings for Individual buildings}

A building owner, a contractor, a policy manager, an energy engineer can obtain an estimate of the direct saving potentials directly from the Tables or Figures. For example, to estimate the savings from the application of a reflective roof on an old (Pre-1980) gas-heated office building with a 10,000- $\mathrm{ft}^{2}$ roof area in Phoenix Arizona, the following steps are taken:

1. From Table 4, the HDD is read at 1154 and the CDD is read at 3815 .

2. From Table $7 \mathrm{a}$ (based on HDD), the annual cooling-energy savings (for an increase in roof albdeo from 0.2 to 0.6 ; a change in albedo of 0.4 ) are read at $776 \mathrm{kWh} / 1000 \mathrm{ft}^{2}$ of roof area, the peak-demand savings are read at $370 \mathrm{~W} / 1000 \mathrm{ft}^{2}$, and the heating penalty is read at 1 therm $/ 1000 \mathrm{ft}^{2}$. (The same information can be extracted from Figure 4a.) Alternatively from Table $7 \mathrm{~b}$ (based on CDD), the annual cooling-energy savings are read at $664 \mathrm{kWh} / 1000 \mathrm{ft}^{2}$ of roof area, the peak-demand savings are read at $237 \mathrm{~W} / 1000 \mathrm{ft}^{2}$, and the heating penalty is read at 1 therm $/ 1000 \mathrm{ft}^{2}$. (The same information can be extracted from Figure 4b.) Hence the total annual cooling-energy savings are estimated at 6640 $7390 \mathrm{kWh}$, the peak-demand reduction is $2.4-3.7 \mathrm{~kW}$, and the annual heating penalty is $1-3$ therms.

3. For other changes in roof reflectivity, simply scale the savings by the ratio $\Delta$ albedo/0.4.

The same table can be used to estimate the saving potentials from shade trees.

\section{Estimating Savings for an Urban Area}

Data in Tables 6-8 and Figures 3-5 can also be used to estimate the potential savings from reflective roofs and shade trees at an urban scale. For demonstration, we present an example of how the data generated in this report can be used to estimate the heat-island reduction saving potential for Houston. The choice of Houston as an example would allow us to compare the results from this report with previous detailed analysis presented in Konopacki and Akbari (2002). This demonstration example is summarized in Table 10. Let us also assume that we would plant 4, 8 and 10 shade trees for the residence, office, and retail store, respectively. Also, the albedo of the residences is increased from 0.2 to 0.5 , and for offices and retail stores it is increased from 0.2 to 0.6 . 


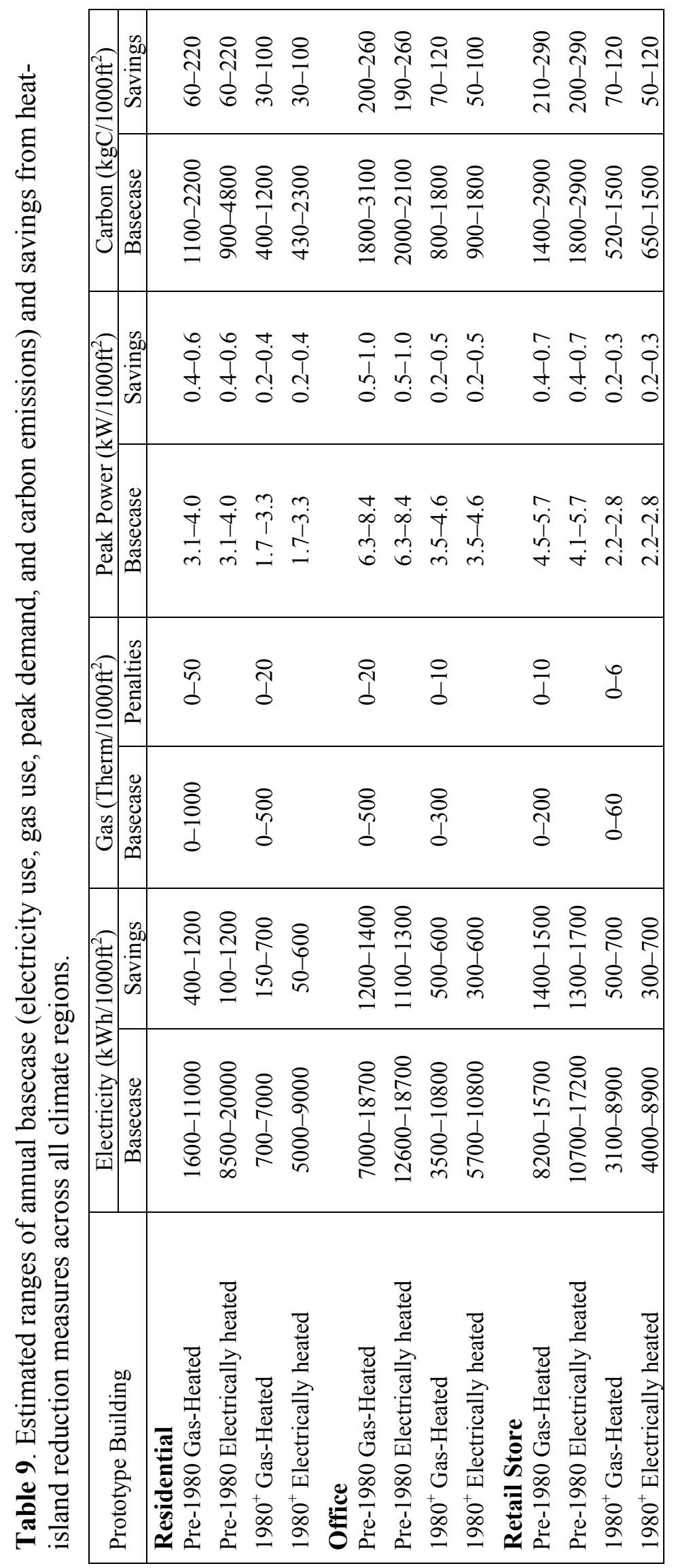


1. Row 1a shows the stock of conditioned roof area for buildings heated with gas: Pre-1980 Residences: $789 \mathrm{Mft}^{2}$; $1980^{+}$Residences: $310 \mathrm{Mft}^{2}$; Pre-1980 Offices: $48 \mathrm{Mft}^{2}$; $1980^{+}$ Offices: $27 \mathrm{Mft}^{2}$; and Pre-1980 Retail Stores: $90 \mathrm{Mft}^{2}$; $1980^{+}$Retail Stores: $19 \mathrm{Mft}^{2}$. Row $1 \mathrm{~b}$ shows the stock of conditioned roof area for buildings heated with electric heat pump: Pre-1980 Residences: $78 \mathrm{Mft}^{2}$; $1980^{+}$Residences: $51 \mathrm{Mft}^{2}$; Pre-1980 Offices: 2.5 $\mathrm{Mft}^{2}$; $1980^{+}$Offices: $4.8 \mathrm{Mft}^{2}$; and Pre-1980 Retail Stores: $4.8 \mathrm{Mft}^{2}$; $1980^{+}$Retail Stores: $0 \mathrm{Mft}^{2}$.

2. Row 2 shows the heating-degree-days (base 65F) read from Table 4.

3. Row 3 shows the cooling-degree-days (base 65F) read from Table 4.

4. Row 4a shows the normalized estimated basecase annual air-conditioning electricity use for a building heated with gas, using the HDD Tables 6a, 7a, and 8a. (Alternatively, CDD Tables $6 \mathrm{~b}, 7 \mathrm{~b}$, and $8 \mathrm{~b}$ can be used.)

Row $4 \mathrm{~b}$ shows the normalized estimated basecase annual air-conditioning electricity use for a building heated with heat pumps, using the HDD Tables 6a, 7a, and 8a.

(Alternatively, CDD Tables $6 \mathrm{~b}, 7 \mathrm{~b}$, and $8 \mathrm{~b}$ can be used.)

Row 4c shows the normalized estimated basecase annual air-conditioning electricity peak power demand for a building heated with wither gas or heat pumps, using the HDD Tables 6a, 7a, and 8a. (Alternatively, CDD Tables 6b, 7b, and $8 \mathrm{~b}$ can be used.) Row 4d shows the normalized estimated basecase annual heating energy use for a building heated with gas, using the HDD Tables 6a, 7a, and 8a. (Alternatively, CDD Tables $6 \mathrm{~b}, 7 \mathrm{~b}$, and $8 \mathrm{~b}$ can be used.)

5. Row 5a shows the normalized estimated annual reflective roofs air-conditioning electricity savings for a building heated with gas, using the HDD Tables 6a, 7a, and 8a. (Alternatively, CDD Tables $6 \mathrm{~b}, 7 \mathrm{~b}$, and $8 \mathrm{~b}$ can be used.) Row $5 \mathrm{~b}$ shows the normalized estimated annual reflective roofs air-conditioning electricity savings for a building heated with heat pumps, using the HDD Tables 6a, 7a, and 8a. (Alternatively, CDD Tables 6b, 7b, and $8 \mathrm{~b}$ can be used.)

Row $5 \mathrm{c}$ shows the normalized estimated annual reflective roofs air-conditioning electricity peak power demand reduction for a building heated with wither gas or heat pumps, using the HDD Tables 6a, 7a, and 8a. (Alternatively, CDD Tables 6b, 7b, and 8b can be used.)

Row $5 \mathrm{~d}$ shows the normalized estimated annual reflective roofs heating energy penalties for a building heated with gas, using the HDD Tables 6a, 7a, and 8a. (Alternatively, CDD Tables $6 \mathrm{~b}, 7 \mathrm{~b}$, and $8 \mathrm{~b}$ can be used.)

6. Row 6a shows the normalized estimated annual shade trees air-conditioning electricity savings for a building heated with gas, using the HDD Tables 6a, 7a, and 8a.

(Alternatively, CDD Tables $6 \mathrm{~b}, 7 \mathrm{~b}$, and $8 \mathrm{~b}$ can be used.) Row $6 \mathrm{~b}$ shows the normalized estimated annual shade trees air-conditioning electricity savings for a building heated with heat pumps, using the HDD Tables 6a, 7a, and 8a. (Alternatively, CDD Tables $6 \mathrm{~b}, 7 \mathrm{~b}$, and $8 \mathrm{~b}$ can be used.)

Row 6c shows the normalized estimated annual shade trees air-conditioning electricity peak power demand reduction for a building heated with wither gas or heat pumps, using the HDD Tables 6a, 7a, and 8a. (Alternatively, CDD Tables 6b, 7b, and 8b can be used.) Row 6d shows the normalized estimated annual shade trees heating energy penalties for a building heated with gas, using the HDD Tables 6a, 7a, and 8a. (Alternatively, CDD Tables $6 \mathrm{~b}, 7 \mathrm{~b}$, and $8 \mathrm{~b}$ can be used.) 
7. Row 7a shows the total estimated basecase annual air-conditioning electricity use for a building heated with gas by multiplying Row 1a by Row 4a.

Row $7 \mathrm{~b}$ shows the total estimated basecase annual air-conditioning electricity use for a building heated with heat pumps by multiplying Row $1 \mathrm{~b}$ by Row $4 \mathrm{~b}$.

Row 7c shows the total estimated basecase annual air-conditioning electricity peak power demand for a building heated with either gas or heat pumps by multiplying (Row 1a + Row $1 \mathrm{~b})$ by Row 4c.

Row 7d shows the total estimated basecase annual heating-energy use for a building heated with gas by multiplying Row 1a by Row 4d.

8. Row 8a shows the estimated total direct reflective roofs annual air-conditioning electricity savings for a building heated with gas by multiplying Row 1a by Row 5a. Row $8 \mathrm{~b}$ shows the estimated total direct reflective roofs annual air-conditioning electricity savings for a building heated with heat pumps by multiplying $\underline{\text { Row } 1 \mathrm{~b}}$ by Row $\underline{5 b}$.

Row 8c shows the estimated total direct reflective roofs annual air-conditioning electricity peak power demand reduction for a building heated with either gas or heat pumps by multiplying ( $\underline{\text { Row } 1 \mathrm{a}}+\underline{\text { Row } 1 \mathrm{~b}}$ ) by Row 5c.

Row 8d shows the estimated total direct reflective roofs annual heating energy penalties for a building heated with gas by multiplying Row 1a by Row $5 \mathrm{~d}$.

9. Row 9a shows the estimated total direct shade trees annual air-conditioning electricity savings for a building heated with gas by multiplying Row 1a by Row 6a.

Row 9b shows the estimated total direct shade trees annual air-conditioning electricity savings for a building heated with heat pumps by multiplying Row $1 \mathrm{~b}$ by Row $6 \mathrm{~b}$.

Row 9c shows the estimated total direct shade trees annual air-conditioning electricity peak power demand reduction for a building heated with either gas or heat pumps by multiplying (Row 1a + Row 1b) by Row 6c.

Row 9d shows the estimated total direct shade trees annual heating energy penalties for a building heated with gas by multiplying Row 1a by Row $6 \mathrm{~d}$.

10. Row 10a shows the estimated total direct reflective roofs and shade trees annual airconditioning electricity savings for a building heated with gas by adding Row 8a and Row 9a.

Row 10b shows the estimated total direct reflective roofs and shade trees annual airconditioning electricity savings for a building heated with heat pumps by adding Row $8 \mathrm{~b}$ and Row 9b.

Row 10c shows the estimated total direct reflective roofs and shade trees annual airconditioning electricity peak power demand reduction for a building heated with either gas or heat pumps by adding Row $8 \mathrm{c}$ and Row 9c.

Row 10d shows the estimated total direct reflective roofs and shade trees annual heating energy penalties for a building heated with gas by adding Row $8 \mathrm{~d}$ and Row 9d.

11. Row 11a shows the estimated total indirect reflective roofs and shade trees annual airconditioning electricity savings for a building heated with gas by multiplying Row 10a by $(0.17 / 0.83)$. (Note that we estimated that the indirect savings are $17 \%$ of the total direct and indirect savings; or $0.17 / 0.83$ of the direct savings.

Row $11 \mathrm{~b}$ shows the estimated total indirect reflective roofs and shade trees annual airconditioning electricity savings for a building heated with heat pumps by multiplying Row $10 \mathrm{~b}$ by $(0.17 / 0.83)$. 
Row 11c shows the estimated total indirect reflective roofs and shade trees annual airconditioning electricity peak power demand reduction for a building heated with either gas or heat pumps by multiplying Row $10 \mathrm{c}$ by $(0.19 / 0.81)$.

Row $11 \mathrm{~d}$ shows the estimated total indirect reflective roofs and shade trees annual heating energy penalties for a building heated with gas by multiplying Row $10 \mathrm{~d}$ by $(0.20 / 0.80)$.

12. Row 12a shows the estimated total direct and indirect reflective roofs and shade trees annual air-conditioning electricity savings for a building heated with gas by adding Row $\underline{10 \mathrm{a}}$ and Row 11a.

Row $12 \mathrm{~b}$ shows the estimated total direct and indirect reflective roofs and shade trees annual air-conditioning electricity savings for a building heated with heat pumps by adding Row $10 \mathrm{~b}$ and Row $11 \mathrm{~b}$.

Row $12 \mathrm{c}$ shows the estimated total direct and indirect reflective roofs and shade trees annual air-conditioning electricity peak power demand reduction for a building heated with either gas or heat pumps by adding Row $10 \mathrm{~b}$ and Row $11 \mathrm{~b}$.

Row $12 \mathrm{~d}$ shows the estimated total direct and indirect reflective roofs and shade trees annual heating energy penalties for a building heated with gas by adding Row $10 \mathrm{~d}$ and Row 11d.

The total annual electricity savings potential obtained by adding all columns of Row 12 a and Row $12 \mathrm{~b}$ is estimated at $1294 \mathrm{GWh}$ (compared to $1,181 \mathrm{GWh}$ estimated by Konopacki and Akbari (2002)). The total electricity peak demand reduction potential is $729 \mathrm{MW}$ (compared to 734 MW estimated by Konopacki and Akbari (2002)). Finally, the total annual heating-gas penalties are 10 Mtherm (compared to 18 Mtherm estimated by Konopacki and Akbari (2002)). Using the data from Cooling-Degree-Days Tables $6 \mathrm{~b}, 7 \mathrm{~b}$, and $8 \mathrm{~b}$, the corresponding electricity savings, peak demand reduction, and heating-gas penalties are estimated at 1,281 GWh, 665 MW, and 9 Mtherm, respectively.

For other changes in roof reflectivity and number of trees, simply adjust the normalized savings (Row 4) as described earlier. 
Table 10. Estimating citywide savings from the implementation of reflective roofs and shade trees: Example of Houston, TX.

\begin{tabular}{|c|c|c|c|c|c|c|}
\hline \multirow[b]{2}{*}{ Item } & \multicolumn{2}{|c|}{ Residence } & \multicolumn{2}{|c|}{ Office } & \multicolumn{2}{|c|}{ Retail Store } \\
\hline & Pre-1980 & $1980^{+}$ & Pre-1980 & $1980^{+}$ & Pre-1980 & $1980^{+}$ \\
\hline $\begin{array}{l}\text { 1a. Building Roof Area Stock with Gas Heating } \\
\text { System }\left(\mathrm{Mft}^{2}\right)\end{array}$ & 789 & 310 & 48 & 27 & 90 & 19 \\
\hline $\begin{array}{l}\text { 1b. Building Roof Area Stock with Heat Pump } \\
\text { System }\left(\mathrm{Mft}^{2}\right)\end{array}$ & 78 & 51 & 2.5 & 4.8 & 4.8 & 0 \\
\hline 2. Heating Degree-Days(base 65F) & 1552 & 1552 & 1552 & 1552 & 1552 & 1552 \\
\hline 3. Cooling Degree-Days (base 65F) & 2810 & 2810 & 2810 & 2810 & 2810 & 2810 \\
\hline $\begin{array}{l}\text { 4a. Estimated basecase electricity use with gas } \\
\text { heating system }\left(\mathrm{kWh} / 1000 \mathrm{ft}^{2}\right)(\text { Table } 6-8 \mathrm{a})\end{array}$ & 5236 & 2968 & 13684 & 7057 & 13486 & 6168 \\
\hline $\begin{array}{l}\text { 4b. Estimated basecase electricity use with heat } \\
\left.\text { pump system }\left(\mathrm{kWh} / 1000 \mathrm{ft}^{2}\right) \text { (Table } 6-8 \mathrm{a}\right)\end{array}$ & 7998 & 3728 & 14565 & 7191 & 13826 & 6177 \\
\hline $\begin{array}{l}\text { 4c. Estimated basecase electricity peak power } \\
\text { demand }\left(\mathrm{W} / 1000 \mathrm{ft}^{2}\right)(\text { Table } 6-8 \mathrm{a})\end{array}$ & 3804 & 2118 & 7890 & 4129 & 5402 & 2672 \\
\hline $\begin{array}{l}\text { 4d. Estimated basecase gas use with gas heating } \\
\text { system }\left(\text { Therm } / 1000 \mathrm{ft}^{2}\right)(\text { Table } 6-8 \mathrm{a})\end{array}$ & 163 & 53 & 76 & 12 & 30 & 0 \\
\hline $\begin{array}{l}\text { 5a. Estimated reflective roofs electricity saving } \\
\text { with gas heating system }\left(\mathrm{kWh} / 1000 \mathrm{ft}^{2}\right)(\text { Table } 6- \\
\text { 8a) }\end{array}$ & 542 & 213 & 739 & 214 & 993 & 298 \\
\hline $\begin{array}{l}\text { 5b. Estimated reflective roofs electricity savings } \\
\text { with heat pump system }\left(\mathrm{kWh} / 1000 \mathrm{ft}^{2}\right)(\text { Table } 6-8 \mathrm{a})\end{array}$ & 463 & 198 & 718 & 205 & 981 & 298 \\
\hline $\begin{array}{l}\text { 5c. Estimated reflective roofs electricity peak } \\
\text { power demand reduction }\left(\mathrm{W} / 1000 \mathrm{ft}^{2}\right)(\text { Table } 6-8 \mathrm{a})\end{array}$ & 333 & 145 & 359 & 92 & 349 & 124 \\
\hline $\begin{array}{l}5 \mathrm{~d} \text {. Estimated reflective roofs gas penalties with gas } \\
\left.\text { heating system }\left(\text { Therm } / 1000 \mathrm{ft}^{2}\right) \text { (Table } 6-8 \mathrm{a}\right)\end{array}$ & -3 & 0 & -2 & 0 & -1 & 0 \\
\hline $\begin{array}{l}\text { 6a. Estimated shade trees electricity saving with gas } \\
\text { heating system }\left(\mathrm{kWh} / 1000 \mathrm{ft}^{2}\right)(\text { Table } 6-8 \mathrm{a})\end{array}$ & 293 & 177 & 501 & 259 & 391 & 190 \\
\hline $\begin{array}{l}\text { 6b. Estimated shade trees electricity savings with } \\
\text { heat pump system }\left(\mathrm{kWh} / 1000 \mathrm{ft}^{2}\right)(\text { Table } 6-8 \mathrm{a})\end{array}$ & 279 & 168 & 494 & 256 & 392 & 191 \\
\hline $\begin{array}{l}\text { 6c. Estimated shade trees electricity peak power } \\
\text { demand reduction }\left(\mathrm{W} / 1000 \mathrm{ft}^{2}\right) \text { (Table 6-8a) }\end{array}$ & 145 & 90 & 323 & 138 & 138 & 59 \\
\hline $\begin{array}{l}\text { 6d. Estimated shade trees gas penalties with gas } \\
\left.\text { heating system }\left(\text { Therm } / 1000 \mathrm{ft}^{2}\right) \text { (Table } 6-8 \mathrm{a}\right)\end{array}$ & -6 & -2 & -2 & 0 & 0 & 0 \\
\hline $\begin{array}{l}\text { 7a. Estimated total electricity use with gas heating } \\
\text { system }(\mathrm{GWh})(1 \mathrm{a} * 4 \mathrm{a})\end{array}$ & 4131 & 920 & 657 & 191 & 1214 & 117 \\
\hline $\begin{array}{l}\text { 7b. Estimated total electricity use with heat pump } \\
\text { system }(\mathrm{GWh})\left(1 \mathrm{~b}^{*} 4 \mathrm{~b}\right)\end{array}$ & 624 & 190 & 36 & 35 & 66 & 0 \\
\hline $\begin{array}{l}\text { 7c. Estimated total electricity peak power demand } \\
(\mathrm{MW})\left((1 \mathrm{a}+1 \mathrm{~b})^{*} 4 \mathrm{c}\right)\end{array}$ & 3298 & 765 & 398 & 131 & 512 & 51 \\
\hline $\begin{array}{l}\text { 7d. Estimated total gas use with gas heating system } \\
\text { (MTherm) }\left(1 \mathrm{a}^{*} 4 \mathrm{~d}\right)\end{array}$ & 129 & 16 & 4 & 0 & 3 & 0 \\
\hline $\begin{array}{l}\text { 8a. Estimated total reflective roofs electricity } \\
\text { savings with gas heating system }(G W h)(1 a * 5 a)\end{array}$ & 428 & 66 & 35 & 6 & 89 & 6 \\
\hline
\end{tabular}




\begin{tabular}{|c|c|c|c|c|c|c|}
\hline \multirow[b]{2}{*}{ Item } & \multicolumn{2}{|c|}{ Residence } & \multicolumn{2}{|c|}{ Office } & \multicolumn{2}{|c|}{ Retail Store } \\
\hline & Pre-1980 & $1980^{+}$ & Pre-1980 & $1980^{+}$ & Pre-1980 & $1980^{+}$ \\
\hline $\begin{array}{l}\text { 8b. Estimated total reflective roofs electricity } \\
\text { savings with heat pump system }(G W h)\left(1 b^{*} 5 b\right)\end{array}$ & 36 & 10 & 2 & 1 & 5 & 0 \\
\hline $\begin{array}{l}\text { 8c. Estimated total reflective electricity peak power } \\
\text { demand reduction }(\mathrm{MW})((1 \mathrm{a}+1 \mathrm{~b}) * 5 \mathrm{c})\end{array}$ & 289 & 52 & 18 & 3 & 33 & 2 \\
\hline $\begin{array}{l}\text { 8d. Estimated total reflective roofs gas penalties } \\
\text { with gas heating system (MTherm) }\left(1 a^{*} 5 \mathrm{~d}\right)\end{array}$ & -2 & 0 & 0 & 0 & 0 & 0 \\
\hline $\begin{array}{l}9 \mathrm{a} \text {. Estimated total shade trees electricity savings } \\
\text { with gas heating system }(\mathrm{GWh})\left(1 \mathrm{a}^{*} 6 \mathrm{a}\right)\end{array}$ & 231 & 55 & 24 & 7 & 35 & 4 \\
\hline $\begin{array}{l}9 \mathrm{~b} \text {. Estimated total shade trees electricity savings } \\
\text { with heat pump system }(\mathrm{GWh})\left(1 \mathrm{~b}^{*} 6 \mathrm{~b}\right)\end{array}$ & 22 & 9 & 1 & 1 & 2 & 0 \\
\hline $\begin{array}{l}9 \mathrm{c} . \text { Estimated total shade trees electricity peak } \\
\text { power demand reduction }(\mathrm{MW})\left((1 \mathrm{a}+1 \mathrm{~b})^{*} 6 \mathrm{c}\right)\end{array}$ & 126 & 32 & 16 & 4 & 13 & 1 \\
\hline $\begin{array}{l}\text { 9d. Estimated total shade trees gas penalties with } \\
\text { gas heating system (MTherm) }\left(1 \mathrm{a}^{*} 6 \mathrm{~d}\right)\end{array}$ & -5 & -1 & 0 & 0 & 0 & 0 \\
\hline $\begin{array}{l}\text { 10a. Estimated total direct electricity savings with } \\
\text { gas heating system }(\mathrm{GWh})(8 \mathrm{a}+9 \mathrm{a})\end{array}$ & 659 & 121 & 60 & 13 & 125 & 9 \\
\hline $\begin{array}{l}\text { 10b. Estimated total direct electricity savings with } \\
\text { heat pump system }(\mathrm{GWh})(8 \mathrm{~b}+9 \mathrm{~b})\end{array}$ & 58 & 19 & 3 & 2 & 7 & 0 \\
\hline $\begin{array}{l}\text { 10c. Estimated total direct lectricity peak power } \\
\text { demand reduction }(\mathrm{MW})(8 \mathrm{c}+9 \mathrm{c})\end{array}$ & 414 & 85 & 34 & 7 & 46 & 3 \\
\hline $\begin{array}{l}\text { 10d. Estimated total direct gas penalties with gas } \\
\text { heating system (MTherm) }(8 a+9 d)\end{array}$ & -7 & -1 & 0 & 0 & 0 & 0 \\
\hline $\begin{array}{l}\text { 11a. Estimated total indirect electricity savings with } \\
\text { gas heating system }(\mathrm{GWh})\left(10 \mathrm{a}^{*}(0.17 / 0.83)\right)\end{array}$ & 135 & 25 & 12 & 3 & 26 & 2 \\
\hline $\begin{array}{l}\text { 11b. Estimated total indirect electricity savings with } \\
\text { heat pump system }(\mathrm{GWh})\left(10 \mathrm{~b}^{*} 0.17 / 0.83\right)\end{array}$ & 12 & 4 & 1 & 0 & 1 & 0 \\
\hline $\begin{array}{l}\text { 11c. Estimated total indirect lectricity peak power } \\
\text { demand reduction }(\mathrm{MW})\left(10 \mathrm{c}^{*} 0.19 / 0.81\right)\end{array}$ & 97 & 20 & 8 & 2 & 11 & 1 \\
\hline $\begin{array}{l}\text { 11d. Estimated total indirect gas penalties with gas } \\
\text { heating system (MTherm) }(10 \mathrm{~d} * 0.20 / 0.80)\end{array}$ & -2 & 0 & 0 & 0 & 0 & 0 \\
\hline $\begin{array}{l}\text { 12a. Estimated total direct }+ \text { indirect electricity } \\
\text { savings with gas heating system }(G W h)(10 a+11 a)\end{array}$ & 794 & 146 & 72 & 15 & 150 & 11 \\
\hline $\begin{array}{l}\text { 12b. Estimated total direct }+ \text { indirect electricity } \\
\text { savings with heat pump system }(\mathrm{GWh})(10 \mathrm{~b}+11 \mathrm{~b})\end{array}$ & 70 & 22 & 4 & 3 & 8 & 0 \\
\hline $\begin{array}{l}\text { 12c. Estimated total direct }+ \text { indirect electricity } \\
\text { peak power demand reduction }(\mathrm{MW})(10 \mathrm{c}+11 \mathrm{c})\end{array}$ & 512 & 105 & 43 & 9 & 57 & 4 \\
\hline $\begin{array}{l}12 \mathrm{~d} \text {. Estimated total direct }+ \text { indirect gas penalties } \\
\text { with gas heating system }(\text { MTherm })(10 \mathrm{~d}+11 \mathrm{~d})\end{array}$ & -9 & -1 & 0 & 0 & 0 & 0 \\
\hline
\end{tabular}




\section{Summary and Conclusions}

In this study, we have developed summary tables (sorted by heating- and cooling-degree-days) to estimate the potential of Heat Island Reduction (HIR) strategies (i.e., solar-reflective roofs, shade trees, reflective pavements and urban vegetation) to reduce cooling-energy use in buildings. The tables provide estimates of savings for both direct effect (reducing heat gain through the building shell) and indirect effect (reducing the ambient air temperature).

To perform this analysis, we focused on three building types that offer the most savings potential: residences, offices, and retail stores. Each building type was characterized in detail by Pre-1980 (old) or $1980^{+}$(new) construction vintage and with natural gas or electricity as heating fuel. We defined prototypical building characteristics for each building type and simulated the impact of HIR strategies on building cooling- and heating-energy use and peak power demand using the DOE-2.1E model and weather data for about 240 locations in the U.S. A statistical analysis of previously completed simulations for five cities was used to estimate the indirect savings. Our simulations included the impact of HIR strategies outlined below.

A. Use of solar-reflective roofing material on building ['cool roofs', direct effect].

B. Placement of deciduous shade trees near south and west walls of buildings ['shade trees', direct effect].

C. Urban reforestation with reflective building surfaces and pavements [indirect effect].

D. Combination of strategies A through $\mathrm{C}$ [direct and indirect effects].

Upon completion of estimating the direct and indirect energy savings for all the locations, we integrated the results in tables arranged by heating- and cooling-degree-days. We considered 15 bins for heating-degree-days, and 11 bins for cooling-degree-days. Energy use and savings were presented per $1000 \mathrm{ft}^{2}$ of roof area. The highlights of the results include:

- For all building types, over $75 \%$ of the total savings were from direct effects of cool roofs and shade trees.

- For Pre-1980 gas-heated residential buildings, the total HIR savings potentials ranged from about $1200 \mathrm{kWh} / 1000 \mathrm{ft}^{2}(15 \%)(\mathrm{HDD}<500)$ to about $500 \mathrm{kWh} / 1000 \mathrm{ft}^{2}(25 \%)$ $(5500<\mathrm{HDD}<6000)$. The heating-energy penalties ranged from 0 to 45 therms $(0-5 \%)$. For $1980^{+}$stock of residential buildings, the total HIR savings potentials ranged from about $600 \mathrm{kWh}(12 \%)(\mathrm{HDD}<500)$ to about $200 \mathrm{kWh}(20 \%)(5500<\mathrm{HDD}<6000)$. The heating-energy penalties ranged from 0 to 20 therms $(0-5 \%)$. The peak demand electricity savings ranged from $0.4-0.6 \mathrm{~kW} / 1000 \mathrm{ft}^{2}$ for Pre-1980 stock and $0.2-0.4$ $\mathrm{kW} / 1000 \mathrm{ft}^{2}$ for $1980^{+}$stock.

- For stock of Pre-1980 gas-heated office buildings, the total HIR savings potentials ranged from about $1200 \mathrm{kWh}(7 \%)(\mathrm{HDD}<500)$ to about $1,400 \mathrm{kWh}(18 \%)(5500<\mathrm{HDD}<6000)$. The heating-energy penalties ranged from 0 to 15 therms $(0-5 \%)$. For $1980^{+}$stock of office buildings, the total HIR savings potentials ranged from about $500 \mathrm{kWh}(5 \%)$ $(\mathrm{HDD}<500)$ to about $500 \mathrm{kWh}(12 \%)(5500<\mathrm{HDD}<6000)$. The heating-energy penalties ranged from 0 to 10 therms $(0-7 \%)$. The peak demand electricity savings ranged from $0.5-1.0 \mathrm{~kW} / 1000 \mathrm{ft}^{2}$ for Pre-1980 stock and $0.2-0.4 \mathrm{~kW} / 1000 \mathrm{ft}^{2}$ for $1980^{+}$stock.

- For stock of Pre-1980 gas-heated retail store buildings, the total HIR savings potentials ranged from about $1,500 \mathrm{kWh}(10 \%)(\mathrm{HDD}<500)$ to about $1,400 \mathrm{kWh}(17 \%)$ 
$(5500<\mathrm{HDD}<6000)$. The heating-energy penalties ranged from 0 to 10 therms $(0-5 \%)$. For $1980^{+}$stock of retail store buildings, the total HIR savings potentials ranged from about $600 \mathrm{kWh}(7 \%)(\mathrm{HDD}<500)$ to about $500 \mathrm{kWh}(14 \%)(5500<\mathrm{HDD}<6000)$. The heating-energy penalties ranged from 0 to 4 therms $(0-13 \%)$. The peak demand electricity savings ranged from $0.4-0.7 \mathrm{~kW} / 1000 \mathrm{ft}^{2}$ for Pre-1980 stock and $0.2-0.3$ $\mathrm{kW} / 1000 \mathrm{ft}^{2}$ for $1980^{+}$stock.

\section{References}

Bretz, S. and H. Akbari. 1997. "Long-Term Performance of High-Albedo Roof Coatings." Energy and Buildings 25:159-167.

Building Energy Simulation Group (BESG). 1990. "Overview of the DOE-2 Building Energy Analysis Program, Version 2.1D." Lawrence Berkeley National Laboratory Report LBL19735, Rev. 1. Berkeley, CA.

Henderson, H. 1998. "Part Load Curves for Use in DOE-2." Draft report prepared for Lawrence Berkeley National Laboratory and Florida Solar Energy Center. CDH Energy Corp. Cazenovia, NY. January 16, 1998.

Konopacki, S. and H. Akbari. 2000. "Energy Savings Calculations for Heat Island Reduction Strategies in Baton Rouge, Sacramento and Salt Lake City." Lawrence Berkeley National Laboratory Report LBNL-42890. Berkeley, CA.

Konopacki, S. and H. Akbari. 1998. "Demonstration of Energy Savings of Cool Roofs: Phase II." Lawrence Berkeley National Laboratory -- Heat Island Group Technical Note. Berkeley, CA.

Konopacki, S., H. Akbari, L. Gartland and L. Rainer. 1998. "Demonstration of Energy Savings of Cool Roofs." Lawrence Berkeley National Laboratory Report LBNL-40673. Berkeley, CA.

Konopacki, S., H. Akbari, M. Pomerantz, S. Gabersek and L. Gartland. 1997. "Cooling Energy Savings Potential of Light-Colored Roofs for Residential and Commercial Buildings in 11 US Metropolitan Areas." Lawrence Berkeley National Laboratory Report LBNL39433. Berkeley, CA.

National Appliance Energy Conservation Act of 1987 (NAECA). 1987.

National Renewable Energy Laboratory (NREL). 1995. "User's Manual for TMY2s."

Parker, D., J. Huang, S. Konopacki, L. Gartland, J. Sherwin and L. Gu. 1998. "Measured and Simulated Performance of Reflective Roofing Systems in Residential Buildings." ASHRAE Transactions 104(1):963-975.

Sherman, M., D. Wilson and D. Kiel. 1986. "Variability in Residential Air Leakage." Measured Air Leakage in Buildings ASTM STP-904. Philadelphia, PA.

US Department of Energy (USDOE). 2001. "Choosing or Upgrading Your Central Air Conditioner." Office of Building Technology, State and Community Programs". http://www.eren.doe.gov/buildings/heatcool_cenair.html.

Winklemann, F., B. Birdsall, W. Buhl, K. Ellington and A. Erdem. 1993. "DOE-2 Supplement Version 2.1E." Lawrence Berkeley National Laboratory Report LBNL-34947. Berkeley, CA. 

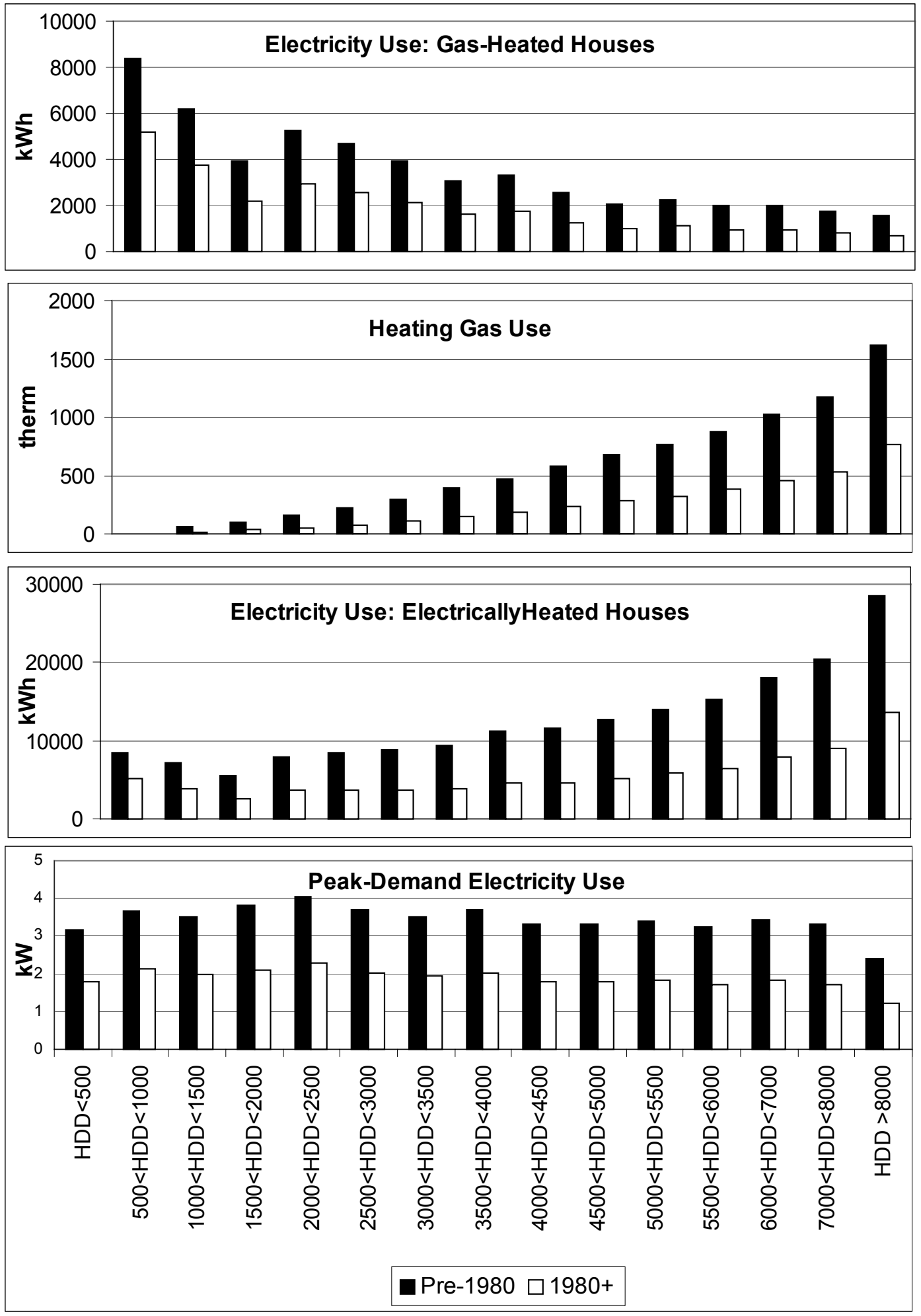

Figure 3a(i). Residential Buildings. Basecase Energy Use as a function of heating-degreeday: Annual basecase cooling-electricity use and heating-gas use for gas-heated houses, combined heating- and cooling-electricity use for electrically heated houses, and peak-electricity demand. All estimates are normalized per $1000 \mathrm{ft}^{2}$ of roof area. 

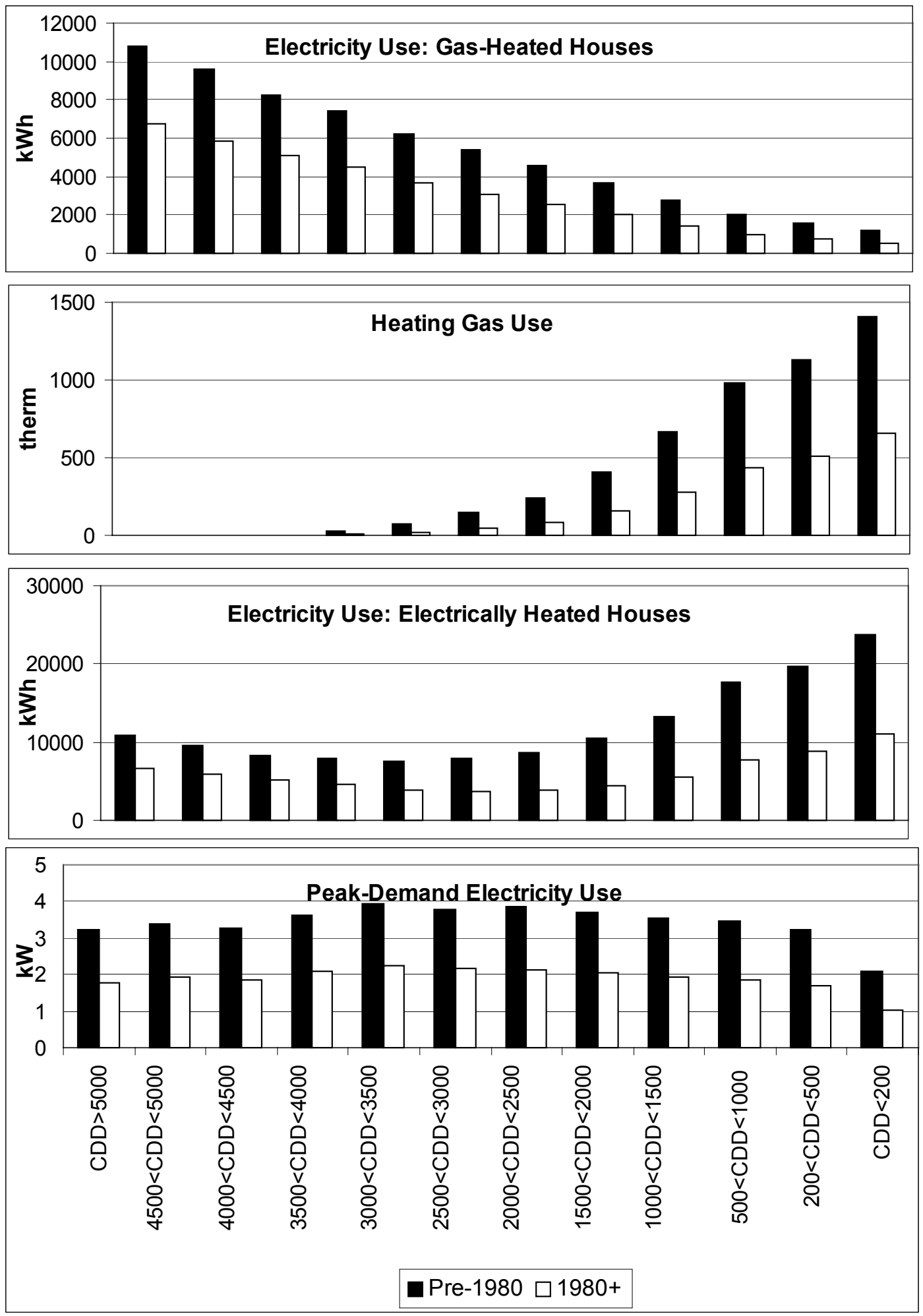

Figure 3b(i). Residential Buildings. Basecase Energy Use as a function of cooling-degreedays: Annual basecase cooling-electricity use and heating-gas use for gas-heated houses, combined cooling-and heating-electricity use for electrically heated houses, and peak-electricity demand. All estimates are normalized per $1000 \mathrm{ft}^{2}$ of roof area. 

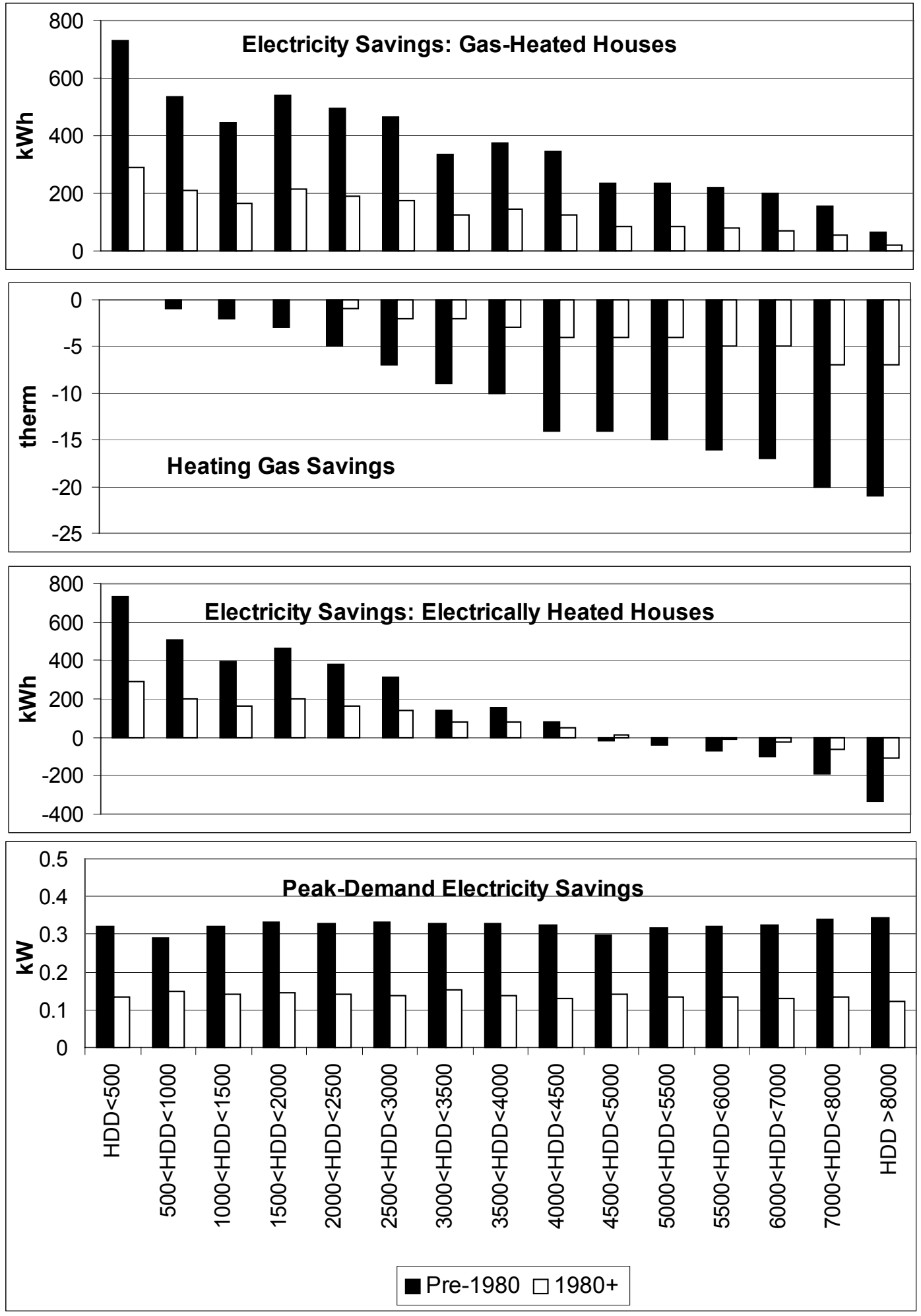

Figure 3a(ii). Residential Buildings. Effect of Cool Roofs, as a function of heating-degreedays: Annual cooling-electricity savings and heating-gas savings for gas-heated houses, combined heating- and cooling-electricity savings for electrically heated houses, and peakelectricity demand savings. All estimates are normalized per $1000 \mathrm{ft}^{2}$ of roof area. 

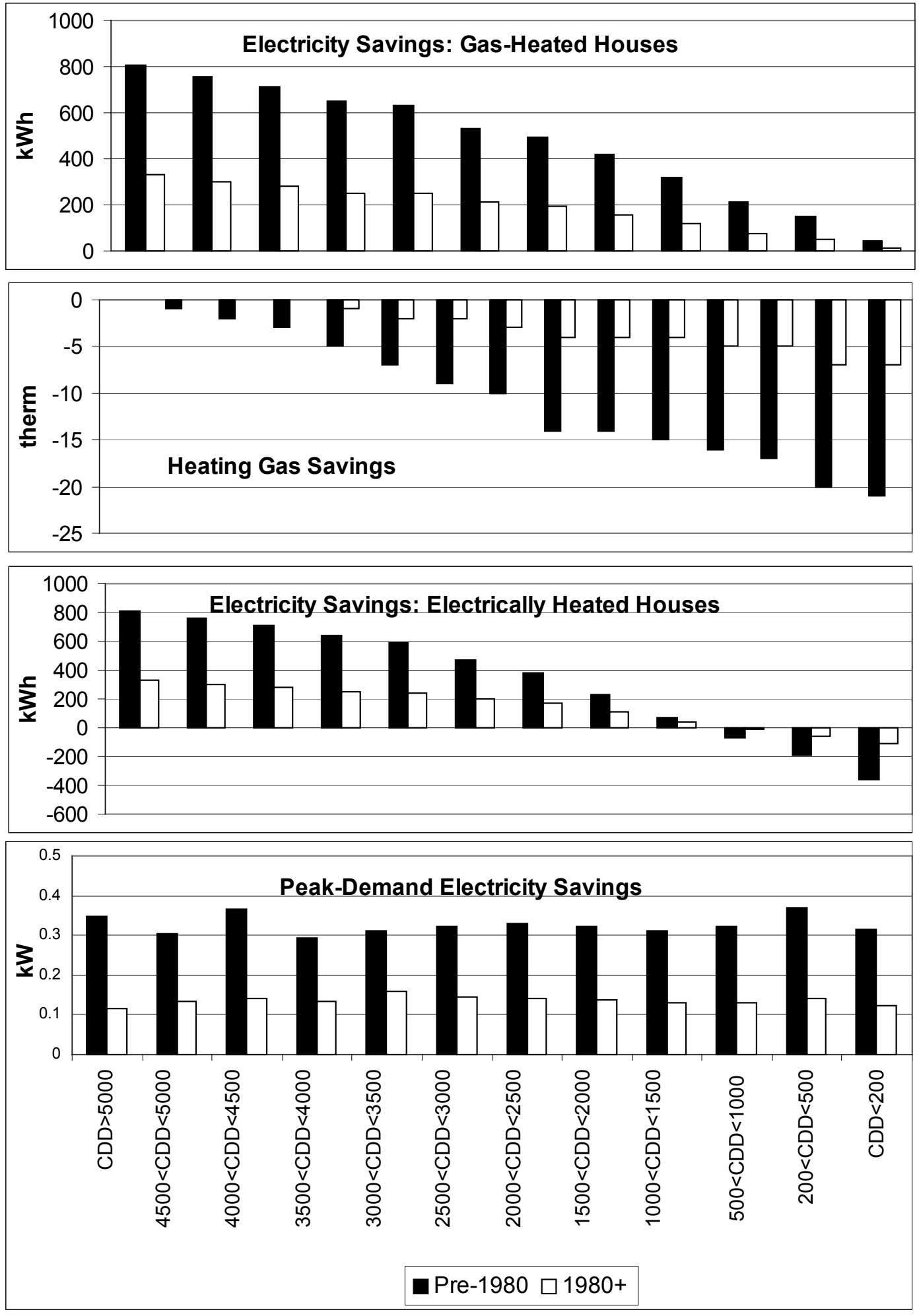

Figure 3b(ii): Residential Buildings. Savings from Cool Roofs as a function of coolingdegree-days: Annual cooling-electricity savings and heating-gas savings for gas-heated houses, combined heating- and cooling-electricity savings for electrically heated houses, and peakelectricity demand savings. All estimates are normalized per $1000 \mathrm{ft}^{2}$ of roof area. 

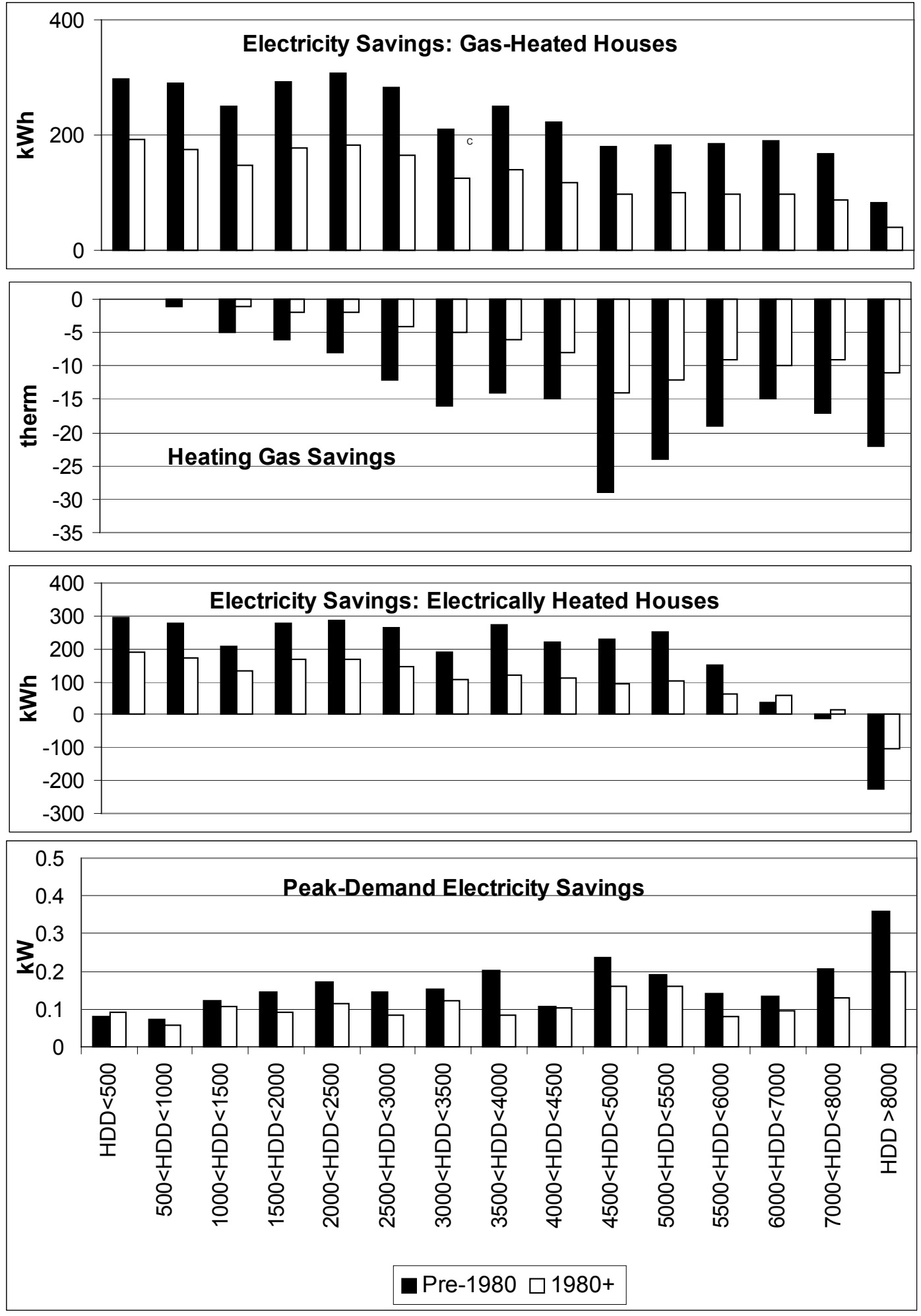

Figure 3a(iii). Residential Buildings. Savings from Shade Trees as a function of heatingdegree-days: Annual cooling-electricity savings and heating-gas savings for gas-heated houses, combined heating- and cooling-electricity savings for electrically heated houses, and peakelectricity demand savings. All estimates are normalized per $1000 \mathrm{ft}^{2}$ of roof area. 

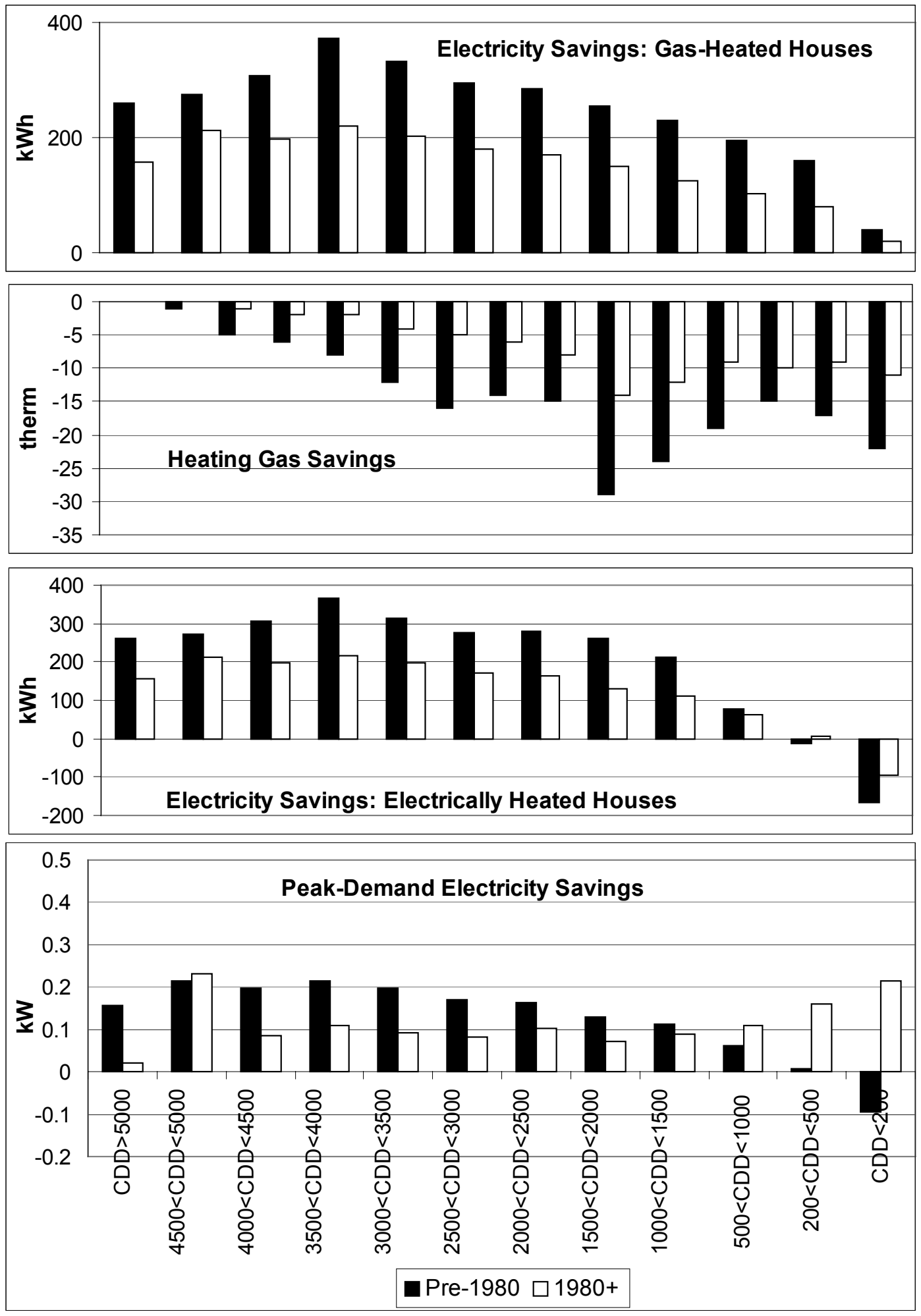

Figure 3b(iii). Residential Buildings. Savings from Shade Trees as a function of coolingdegree-days: Annual cooling-electricity savings and heating-gas savings for gas-heated houses, combined heating- and cooling-electricity savings for electrically heated houses, and peakelectricity demand savings. All estimates are normalized per $1000 \mathrm{ft}^{2}$ of roof area. 

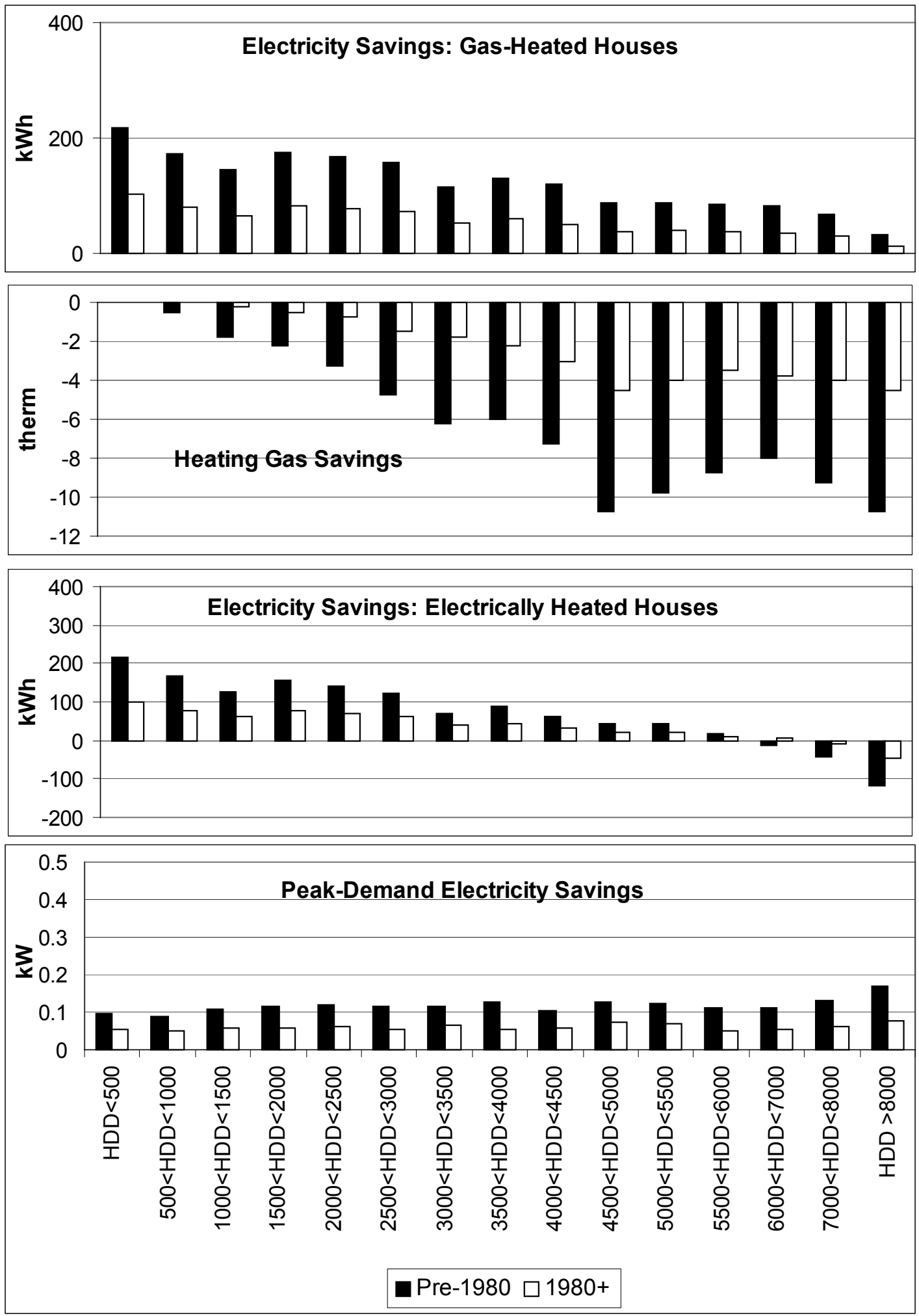

Figure 3a(iv). Residential Buildings. Indirect Savings as a function of heating-degree-days: Annual cooling-electricity savings and heating-gas savings for gas-heated houses, combined heating- and cooling-electricity savings for electrically heated houses, and peak-electricity demand savings. All estimates are normalized per $1000 \mathrm{ft}^{2}$ of roof area. 

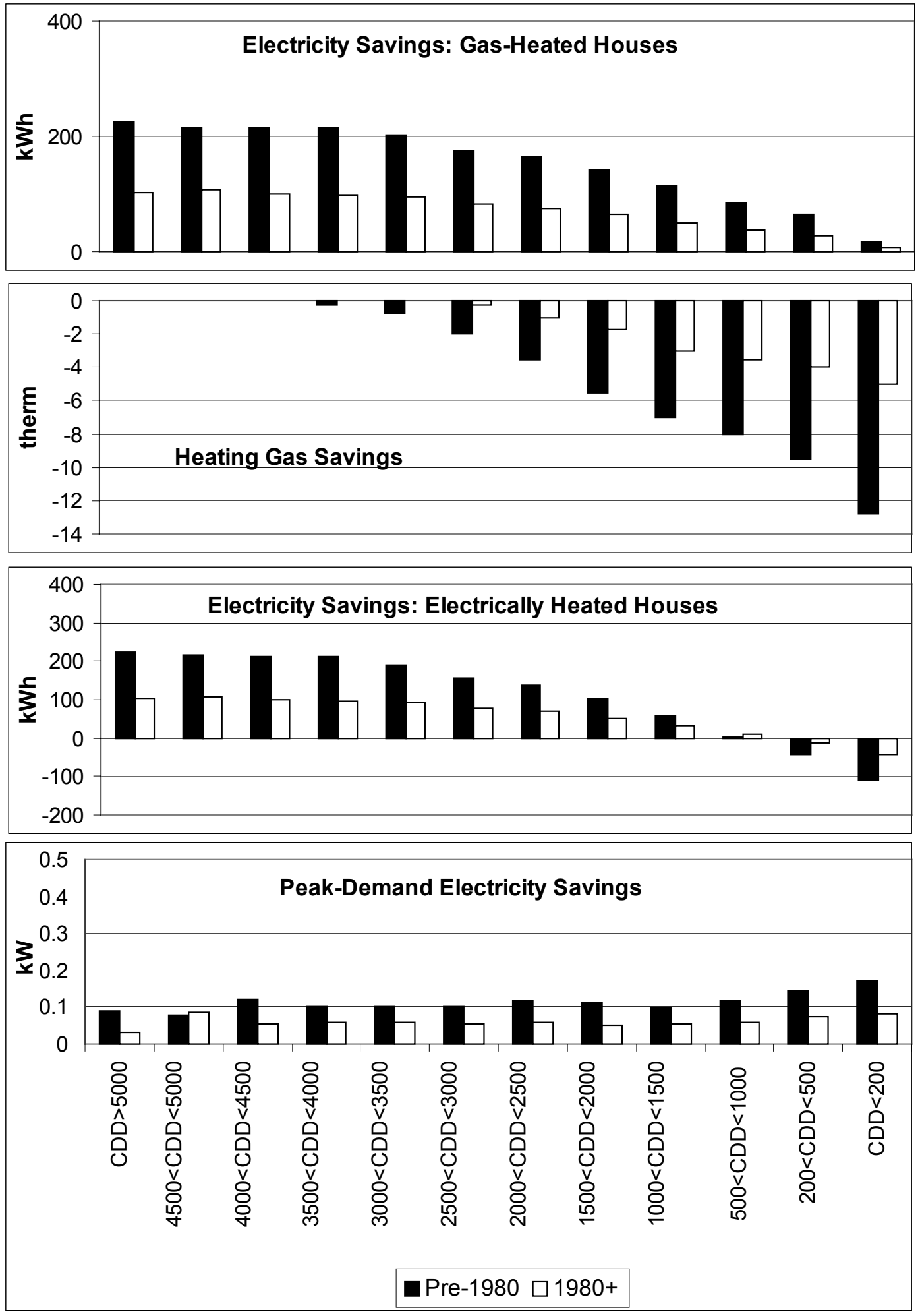

Figure 3b(iv). Residential Buildings. Indirect Savings as a function of cooling degree days: Annual cooling-electricity savings and heating-gas savings for gas-heated houses, combined heating- and cooling-electricity savings for electrically heated houses, and peak-electricity demand savings. All estimates are normalized per $1000 \mathrm{ft}^{2}$ of roof area. 

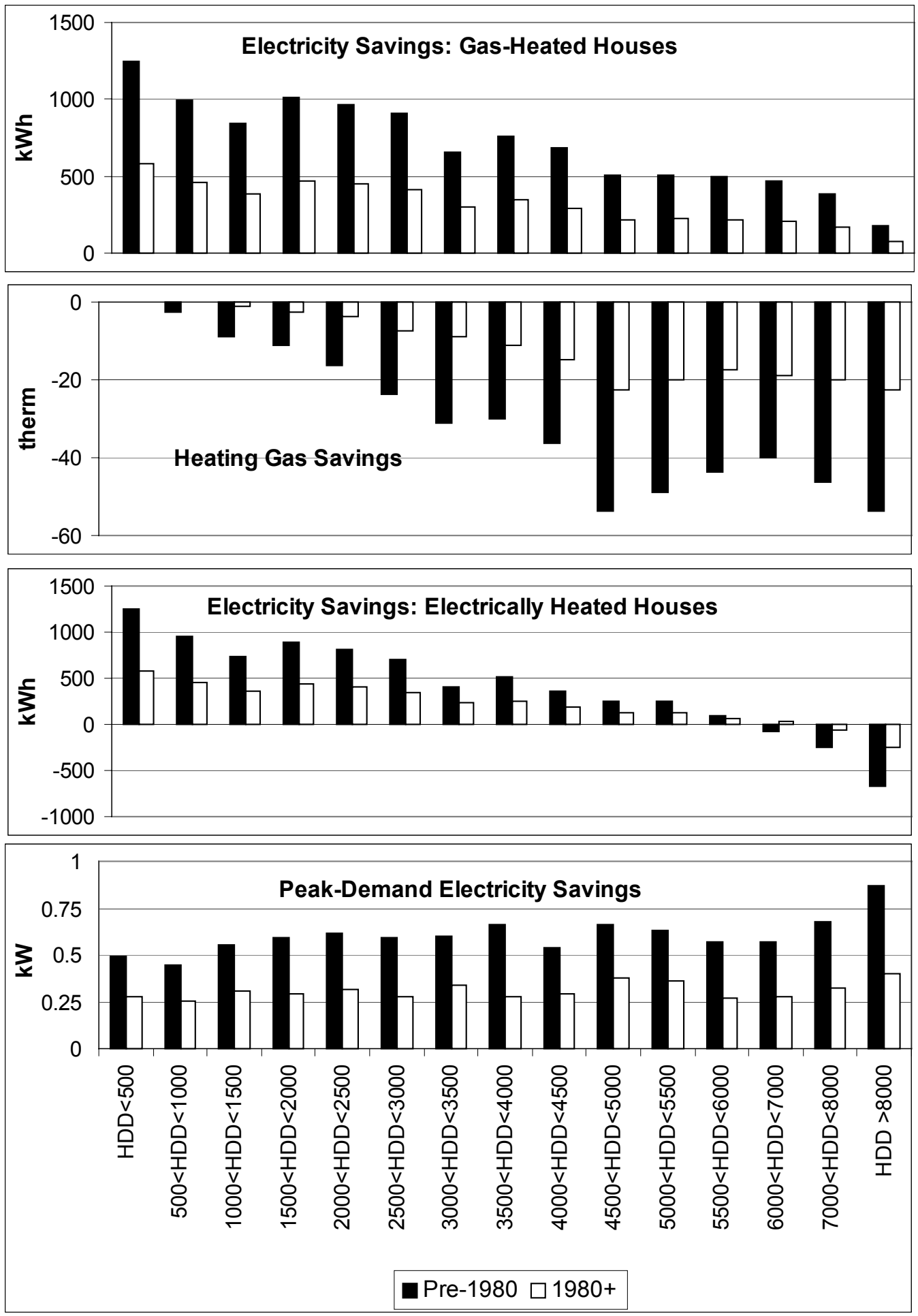

Figure 3a(v). Residential Buildings. Combined Direct and Indirect Savings as a function of heating-degree-days: Annual cooling-electricity savings and heating-gas savings for gas-heated houses, combined heating- and cooling-electricity savings for electrically heated houses, and peak-electricity demand savings. All estimates are normalized per $1000 \mathrm{ft}^{2}$ of roof area. 

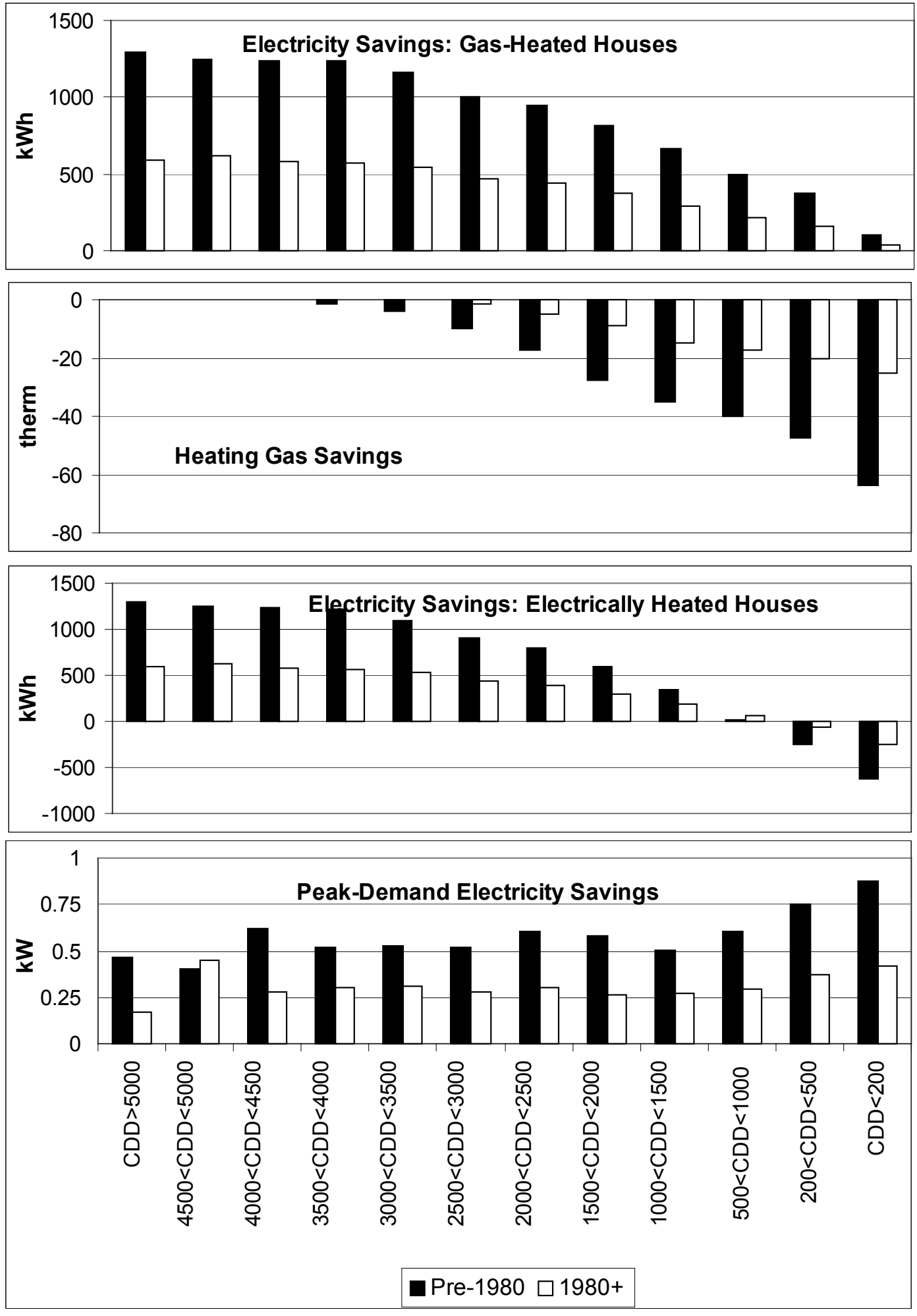

Figure 3b(v). Residential Buildings. Combined Direct and Indirect Savings as a function of cooling-degree-days: Annual cooling electricity savings and heating gas savings for gas heated houses, combined heating and cooling electricity savings for electricity heated houses, and peak electricity demand savings. All estimates are normalized per $1000 \mathrm{ft}^{2}$ of roof area. 

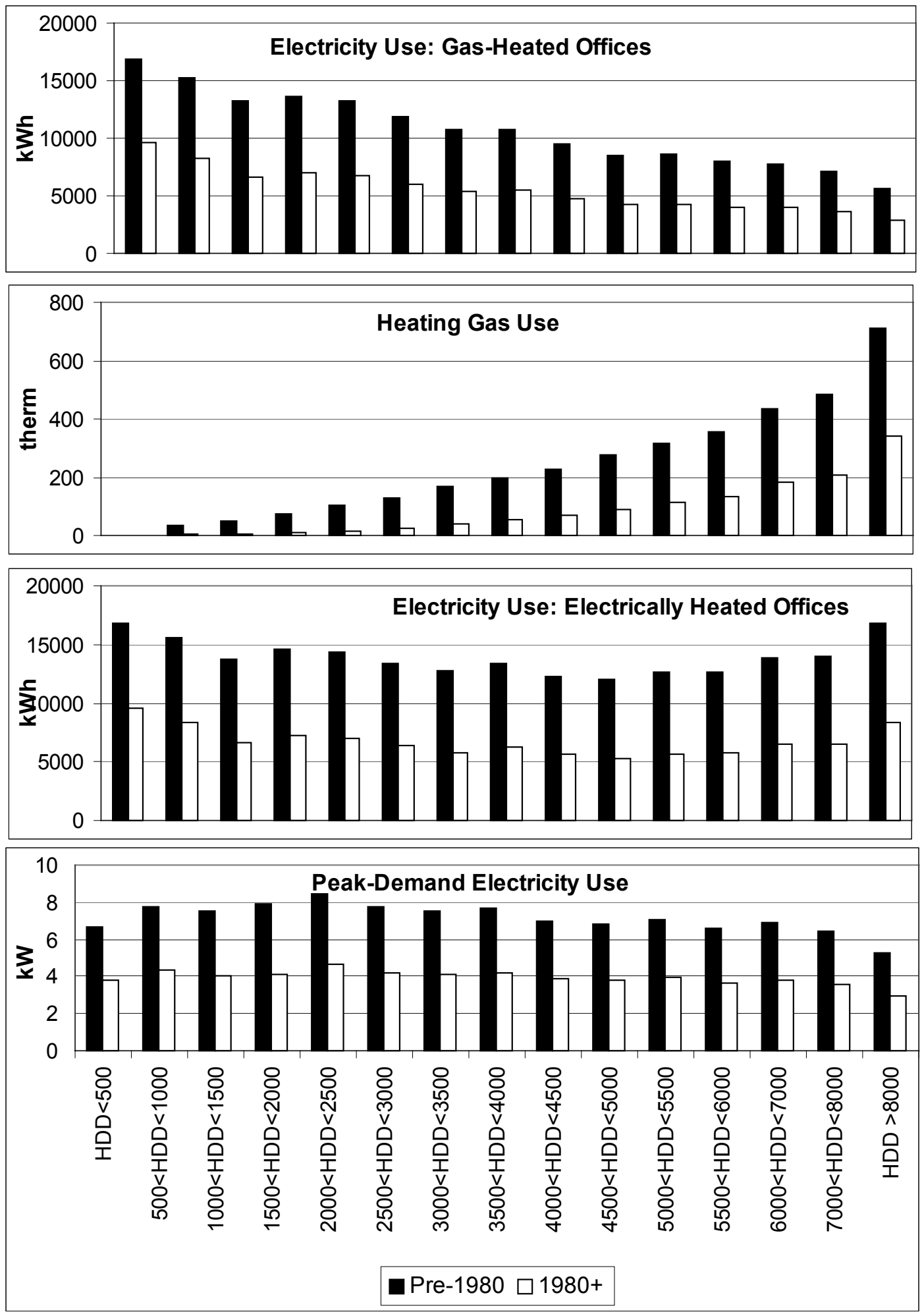

Figure 4a(i). Office Buildings. Basecase Energy Use as a function of heating-degree-days: Annual basecase cooling-electricity use and heating-gas use for gas-heated houses, combined heating- and cooling-electricity use for electrically heated houses, and peak-electricity demand. All estimates are normalized per $1000 \mathrm{ft}^{2}$ of roof area. 

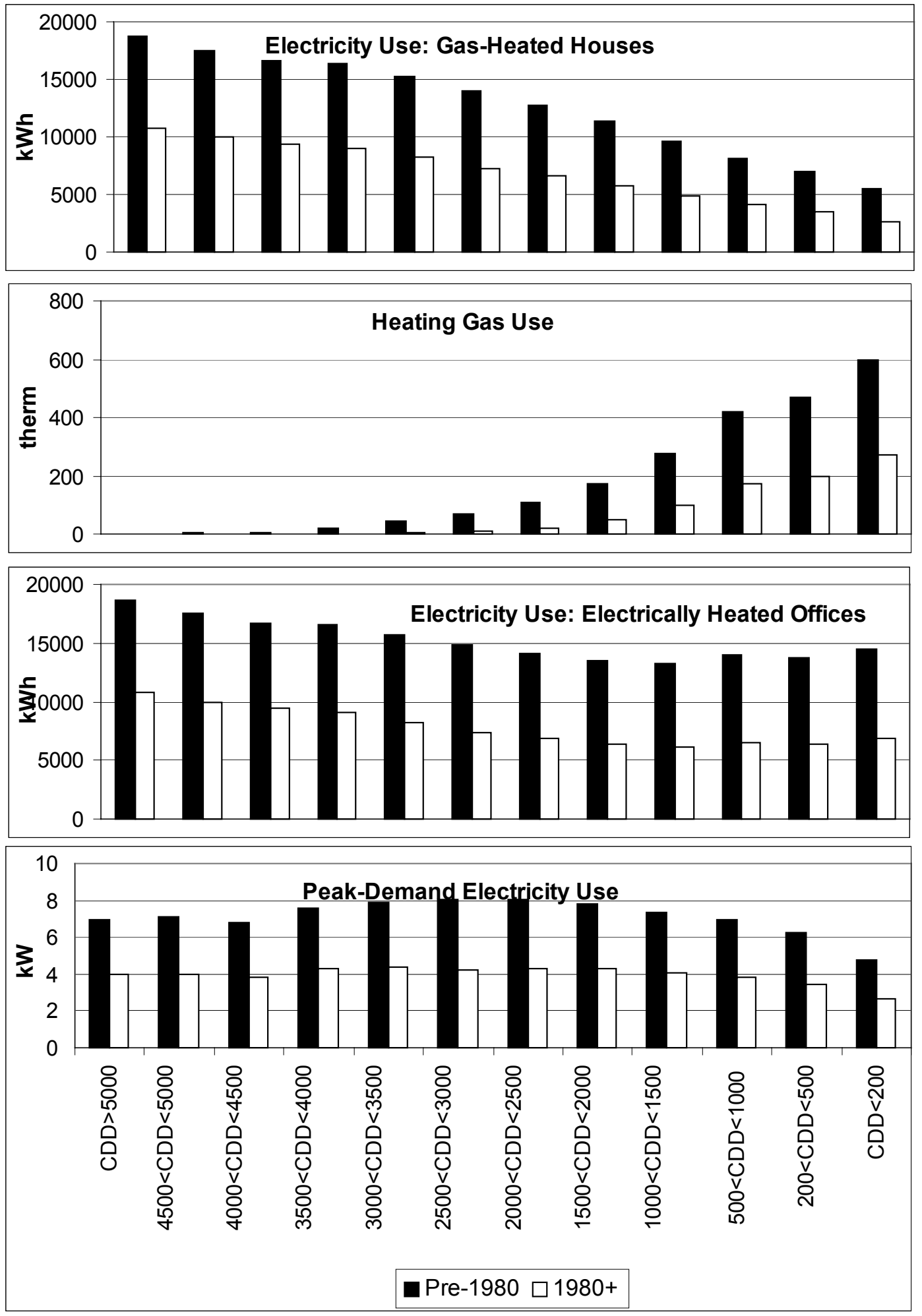

Figure 4b(i). Office Buildings. Basecase Energy Use as a function of cooling-degree-days: Annual basecase cooling-electricity use and heating-gas use for gas-heated houses, combined cooling- and heating-electricity use for electrically heated houses, and peak-electricity demand. All estimates are normalized per $1000 \mathrm{ft}^{2}$ of roof area. 

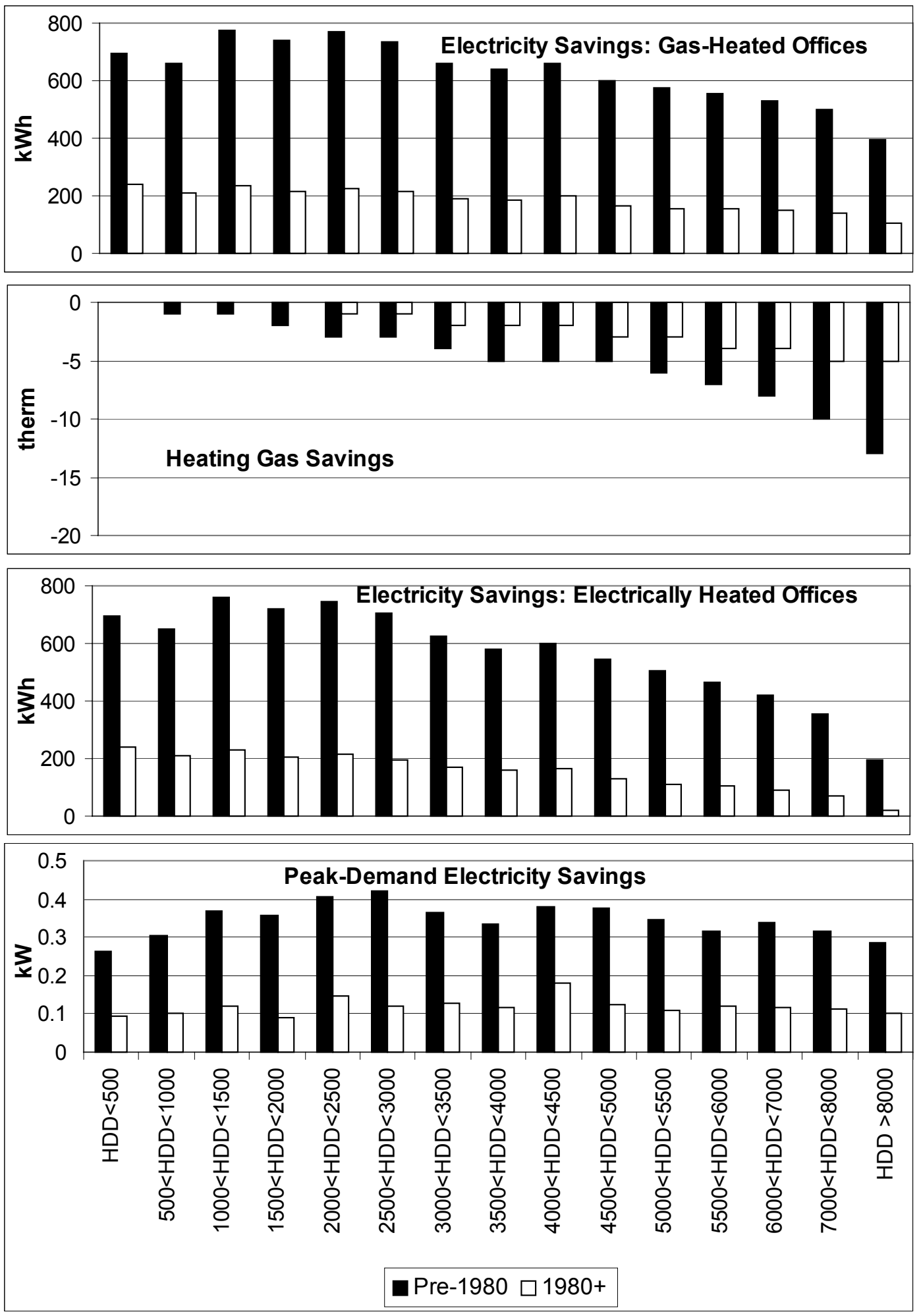

Figure 4a(ii). Office Buildings. Effect of Cool Roofs, as a function of heating-degree-days: Annual cooling-electricity savings and heating-gas savings for gas-heated houses, combined heating- and cooling-electricity savings for electrically heated houses, and peak-electricity demand savings. All estimates are normalized per $1000 \mathrm{ft}^{2}$ of roof area. 

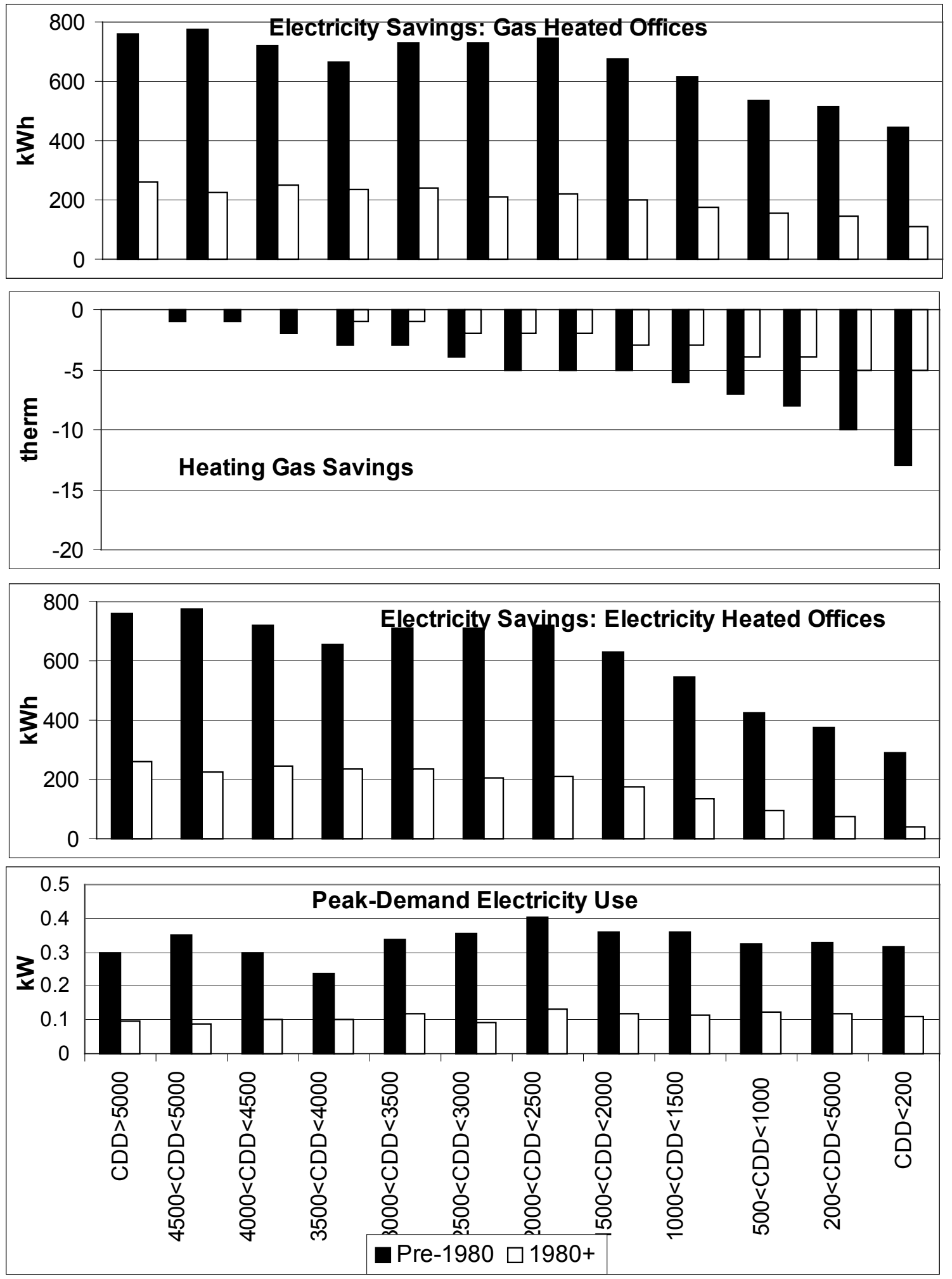

Figure 4b(ii). Office Buildings. Savings from Cool Roofs as a function of cooling-degreedays: Annual cooling-electricity savings and heating-gas savings for gas-heated houses, combined heating- and cooling-electricity savings for electrically heated houses, and peakelectricity demand savings. All estimates are normalized per $1000 \mathrm{ft}^{2}$ of roof area. 

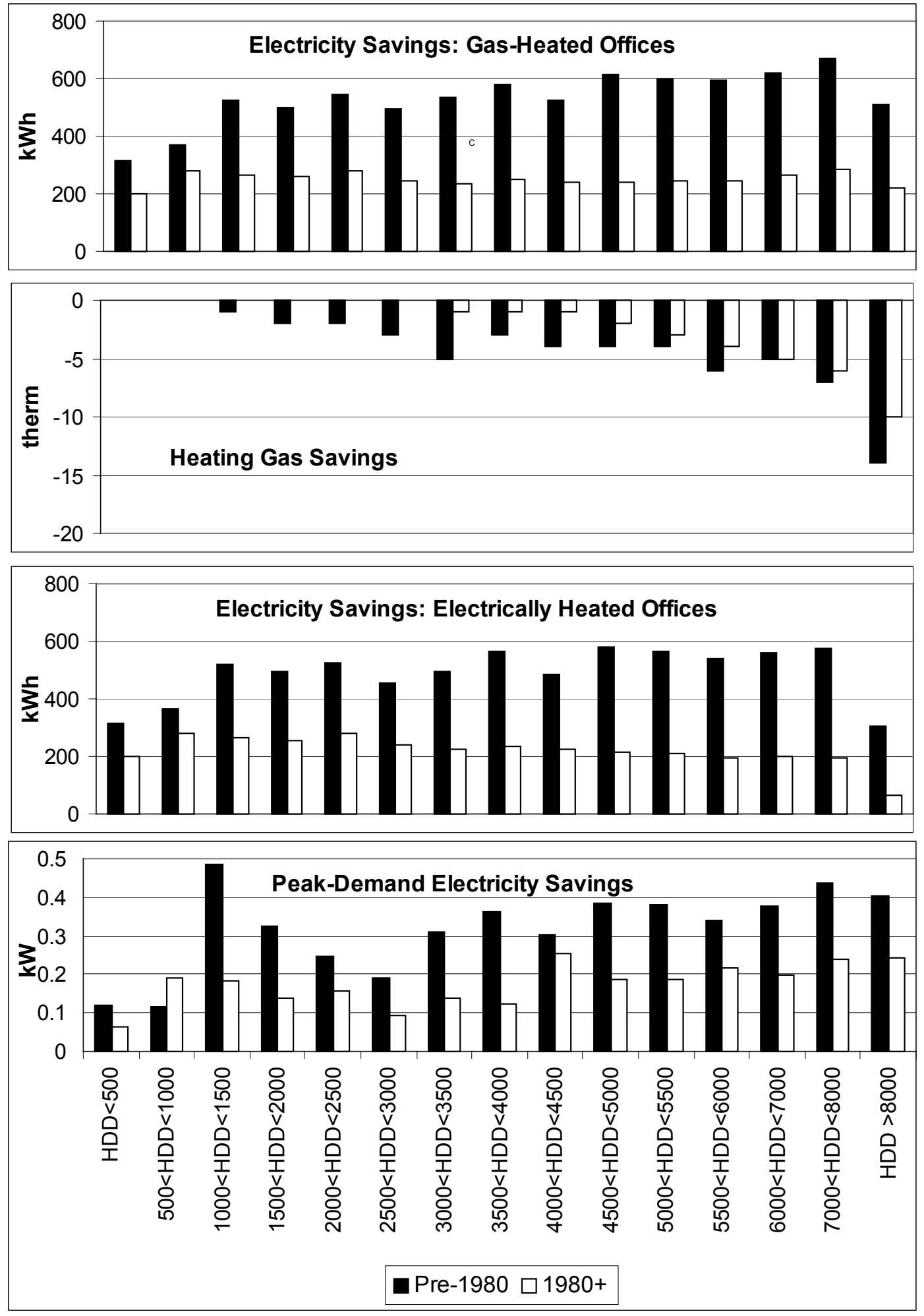

Figure 4a(iii). Office Buildings. Savings from Shade Trees as a function of heating-degreedays: Annual cooling-electricity savings and heating-gas savings for gas-heated houses, combined heating- and cooling-electricity savings for electrically heated houses, and peakelectricity demand savings. All estimates are normalized per $1000 \mathrm{ft}^{2}$ of roof area. 

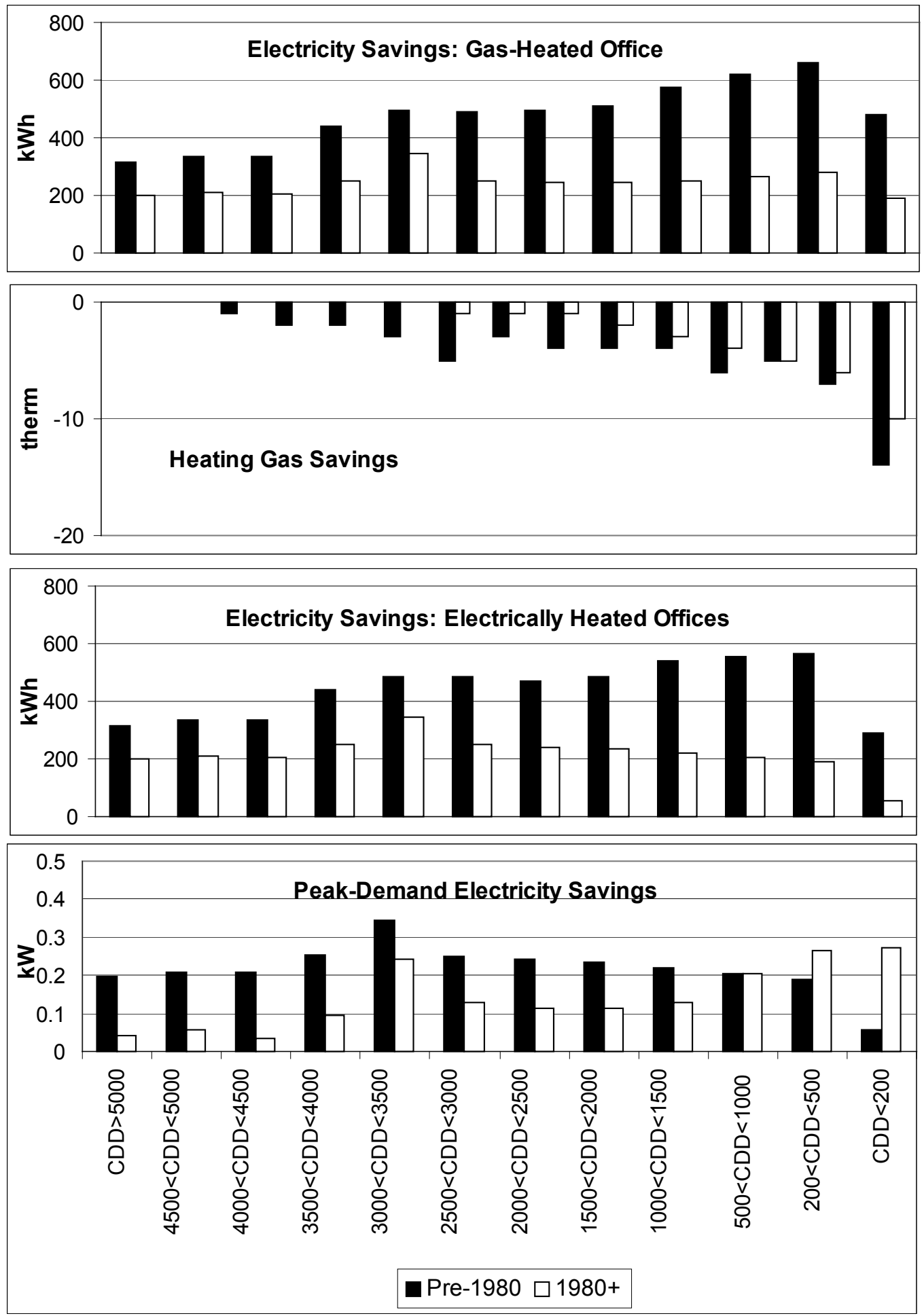

Figure $4 b(i i i)$. Office Buildings. Savings from Shade Trees as a function of cooling-degreedays: Annual cooling-electricity savings and heating-gas savings for gas-heated houses, combined heating- and cooling-electricity savings for electrically heated houses, and peakelectricity demand savings. All estimates are normalized per $1000 \mathrm{ft}^{2}$ of roof area. 

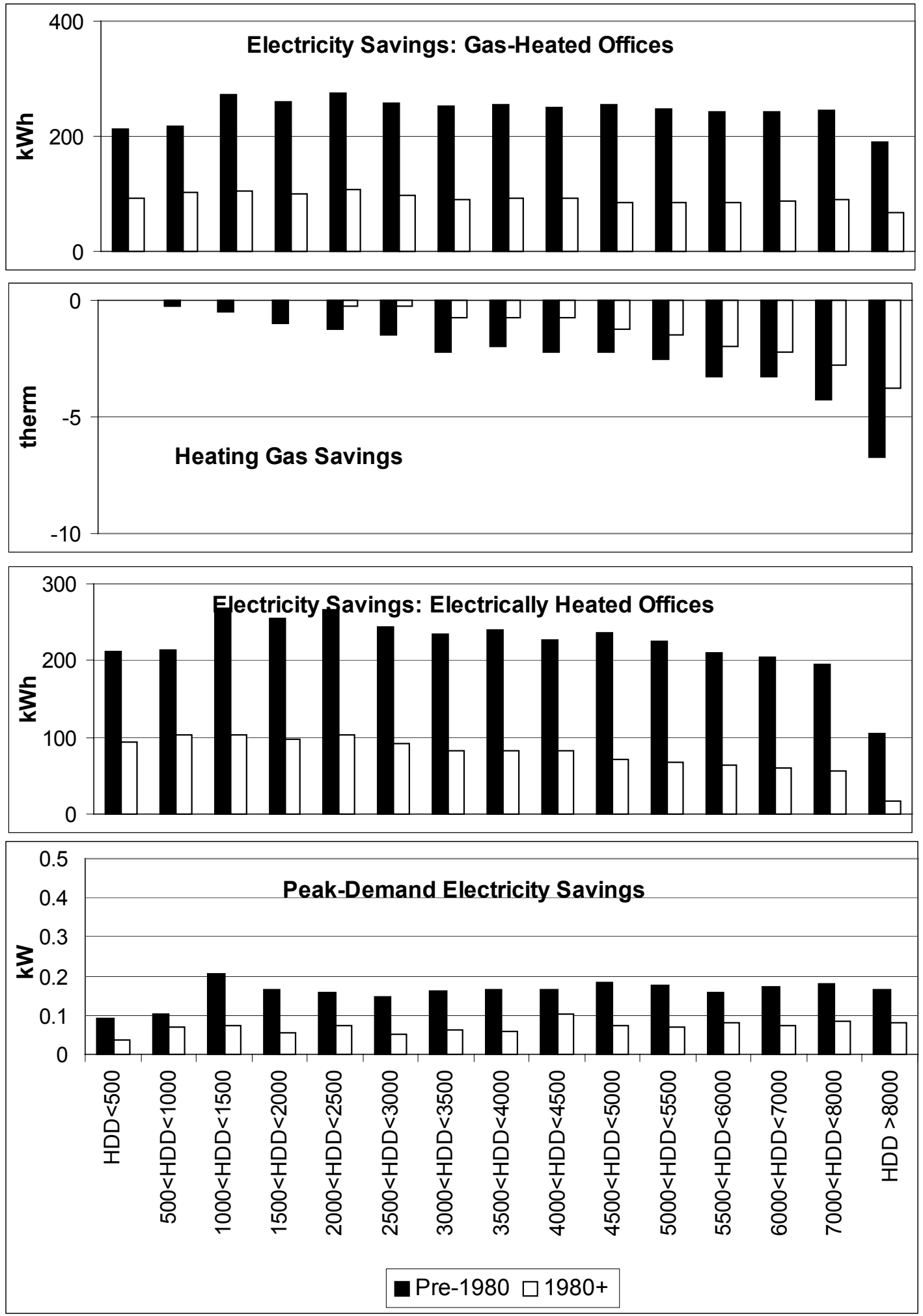

Figure 4a(iv). Office Buildings. Indirect Savings as a function of heating-degree-days: Annual cooling-electricity savings and heating-gas savings for gas-heated houses, combined heating- and cooling-electricity savings for electrically heated houses, and peak-electricity demand savings. All estimates are normalized per $1000 \mathrm{ft}^{2}$ of roof area. 

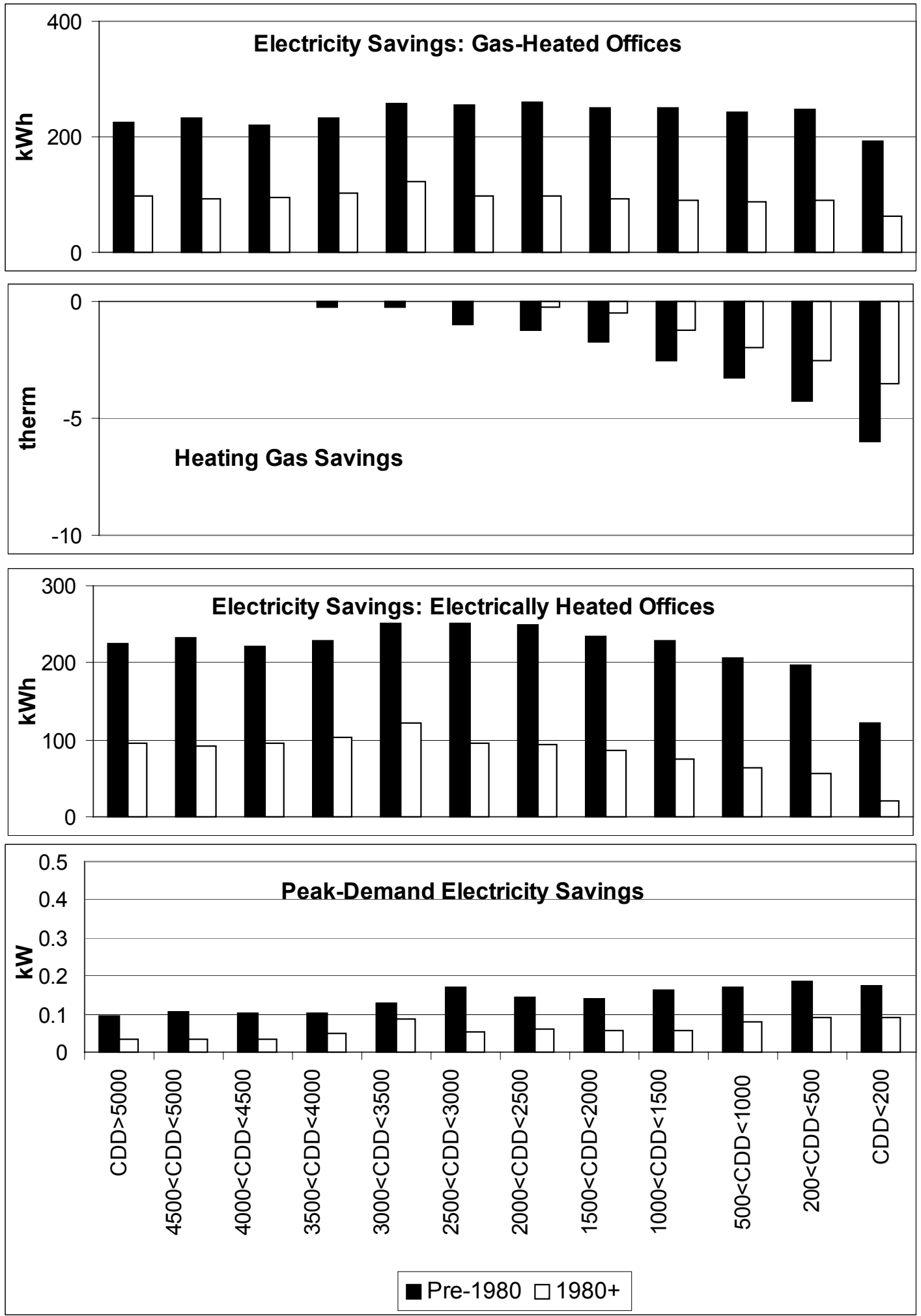

Figure 4b(iv). Office Buildings. Indirect Savings as a function of cooling-degree-days: Annual cooling-electricity savings and heating-gas savings for gas-heated houses, combined heating- and cooling-electricity savings for electrically heated houses, and peak-electricity demand savings. All estimates are normalized per $1000 \mathrm{ft}^{2}$ of roof area. 

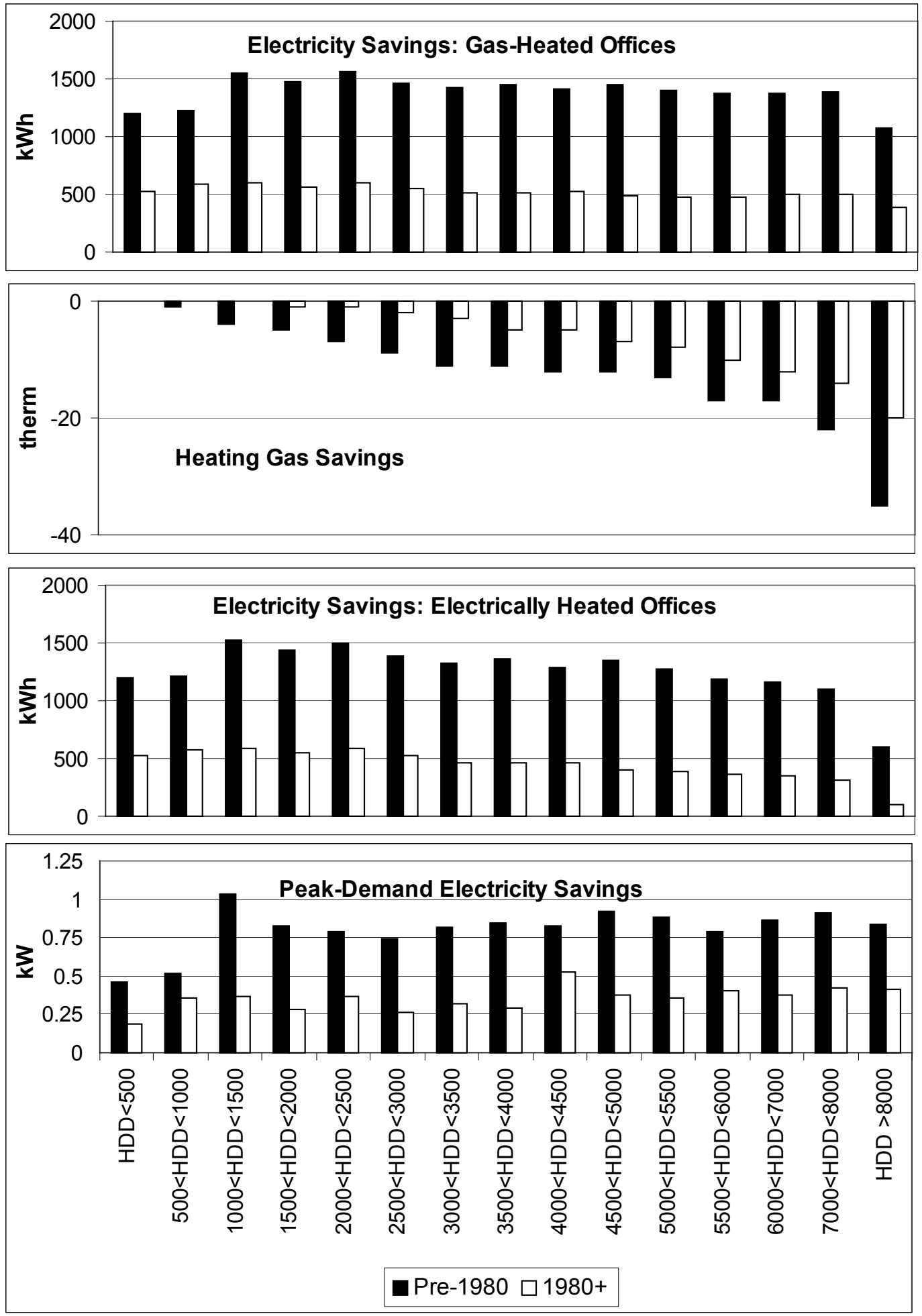

Figure 4a(v). Office Buildings. Combined Direct and Indirect Savings as a function of heating-degree-days: Annual cooling-electricity savings and heating-gas savings for gas-heated houses, combined heating- and cooling-electricity savings for electrically heated houses, and peak-electricity demand savings. All estimates are normalized per $1000 \mathrm{ft}^{2}$ of roof area. 

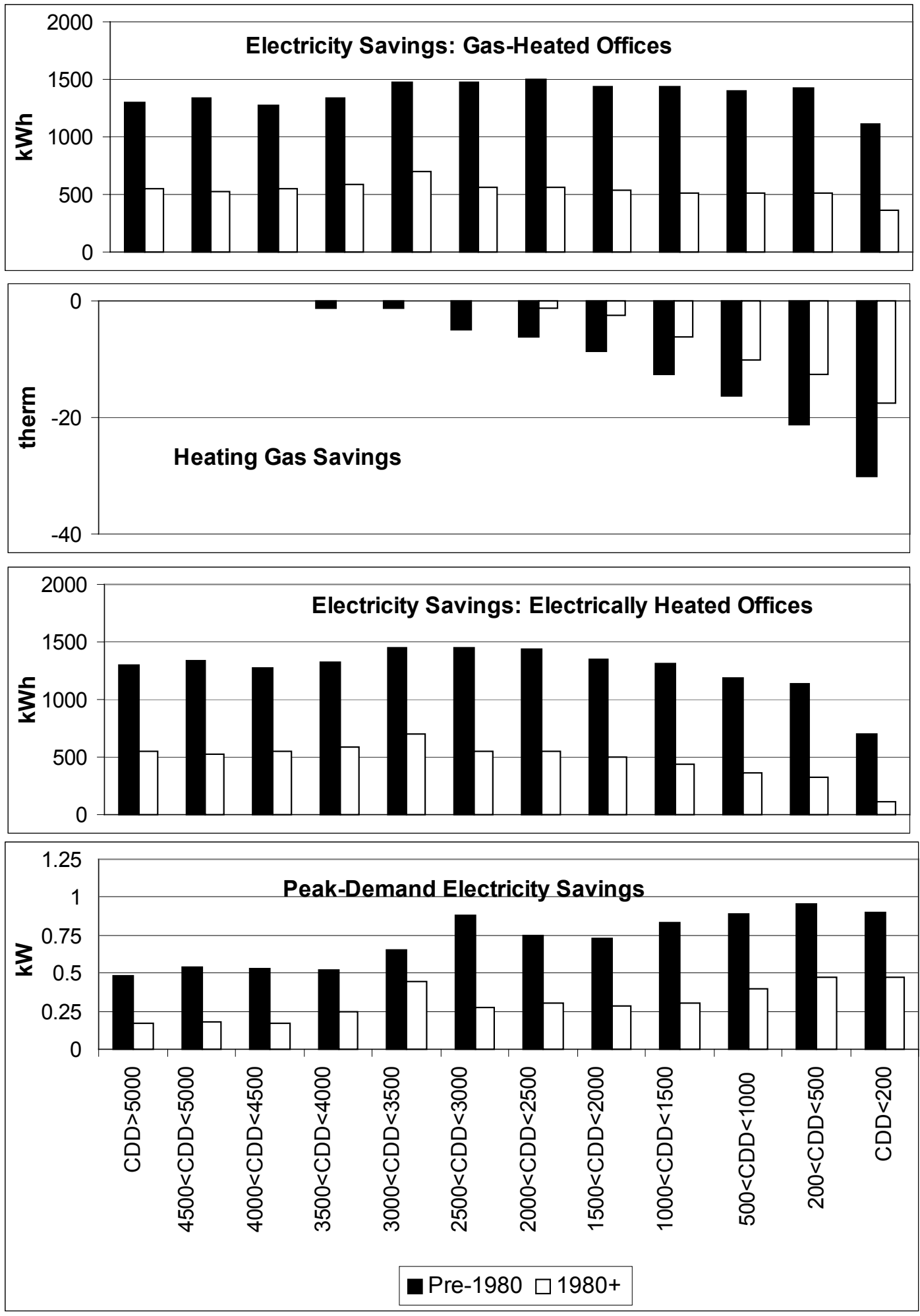

Figure 4b(v). Office Buildings. Combined Direct and Indirect Savings as a function of cooling-degree-days: Annual cooling-electricity savings and heating-gas savings for gas-heated houses, combined heating- and cooling-electricity savings for electrically heated houses, and peak-electricity demand savings. All estimates are normalized per $1000 \mathrm{ft}^{2}$ of roof area. 

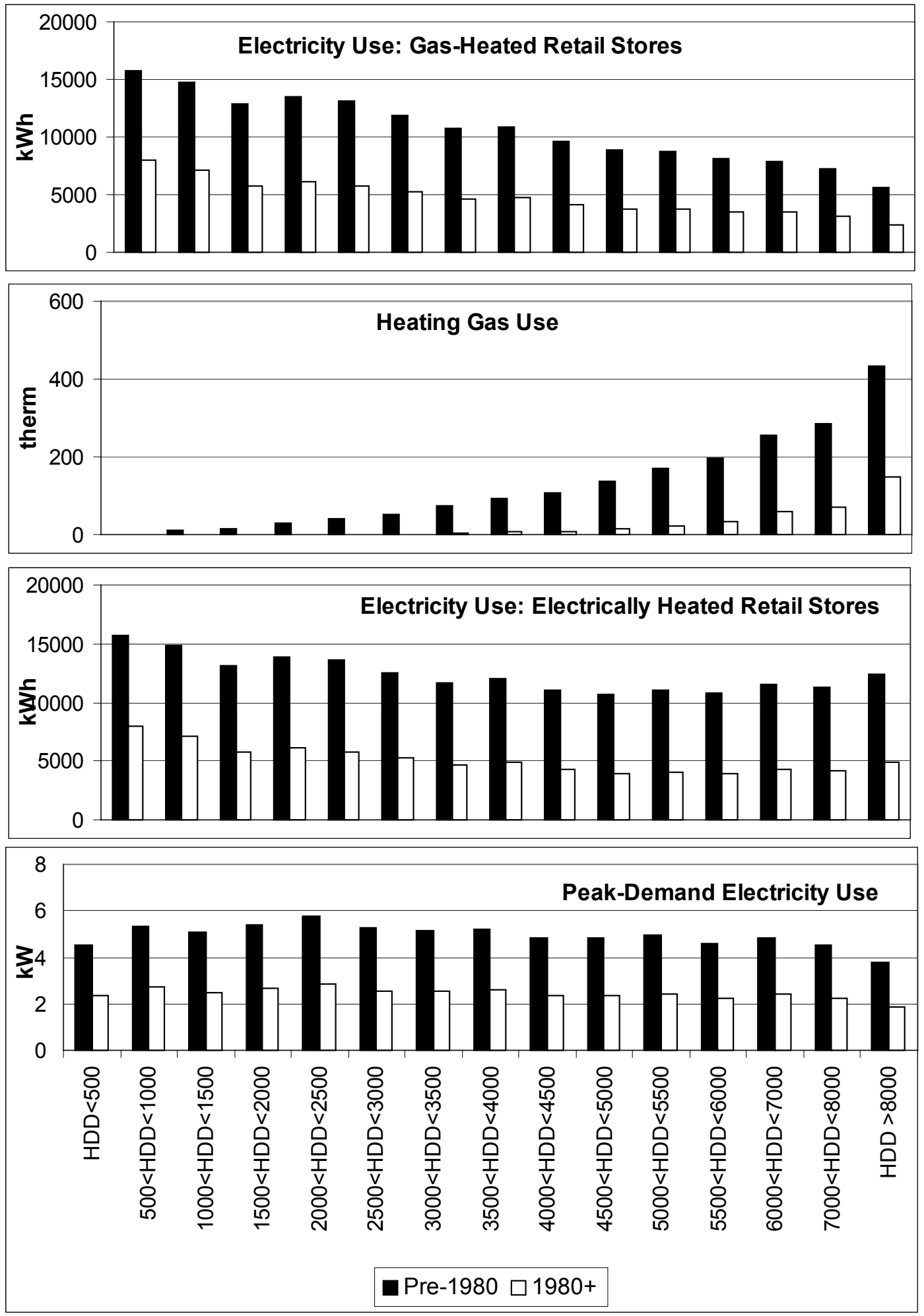

Figure 5a(i). Retail Store Buildings. Basecase Energy Use as a function of heating-degreeday: Annual basecase cooling-electricity use and heating-gas use for gas-heated houses, combined heating- and cooling-electricity use for electrically heated houses, and peak-electricity demand. All estimates are normalized per $1000 \mathrm{ft}^{2}$ of roof area. 

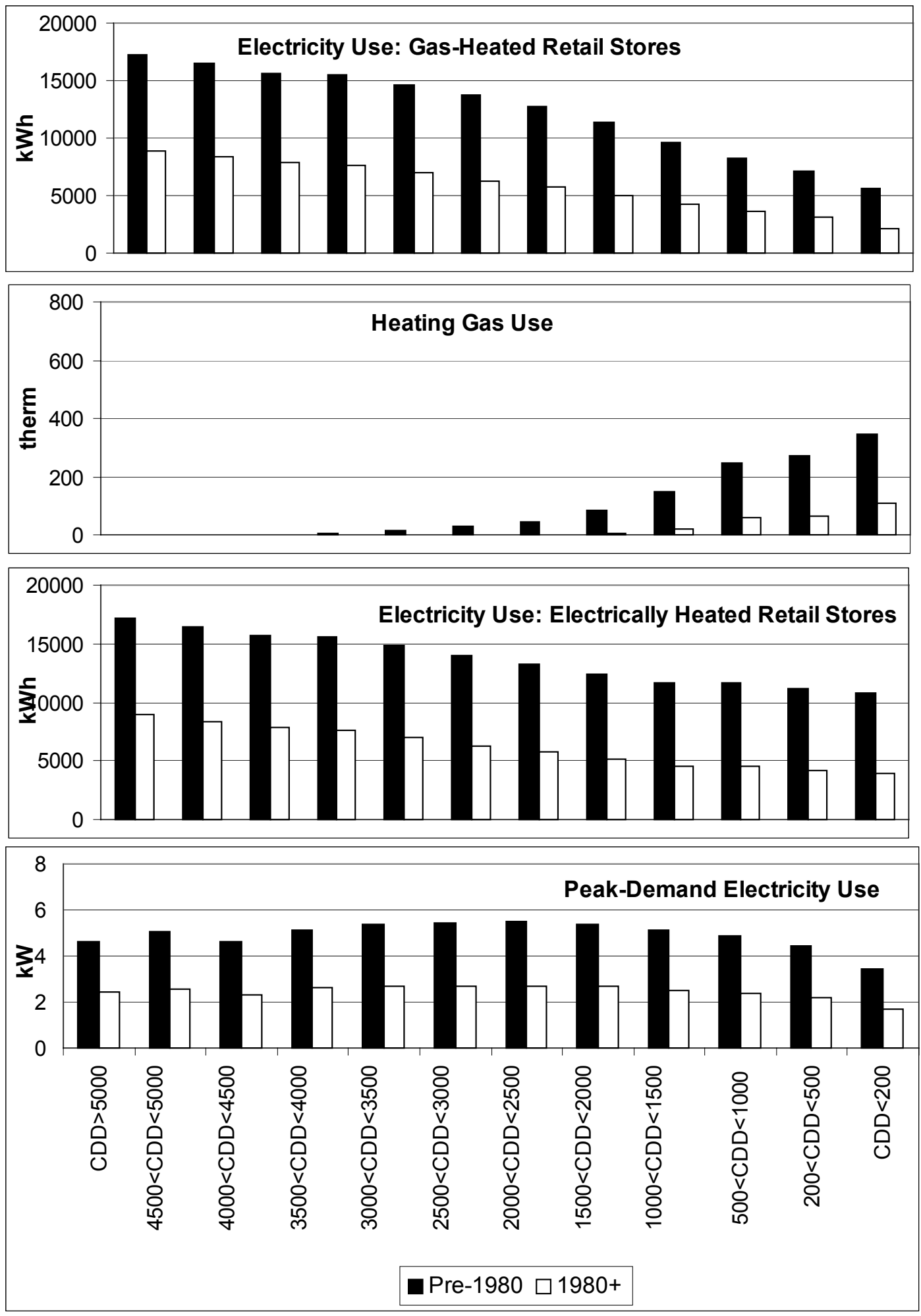

Figure 5b(i). Retail Store Buildings. Basecase Energy Use as a function of cooling-degreedays: Annual basecase cooling-electricity use and heating-gas use for gas-heated houses, combined heating- and cooling-electricity use for electrically heated houses, and peak-electricity demand. All estimates are normalized per $1000 \mathrm{ft}^{2}$ of roof area. 

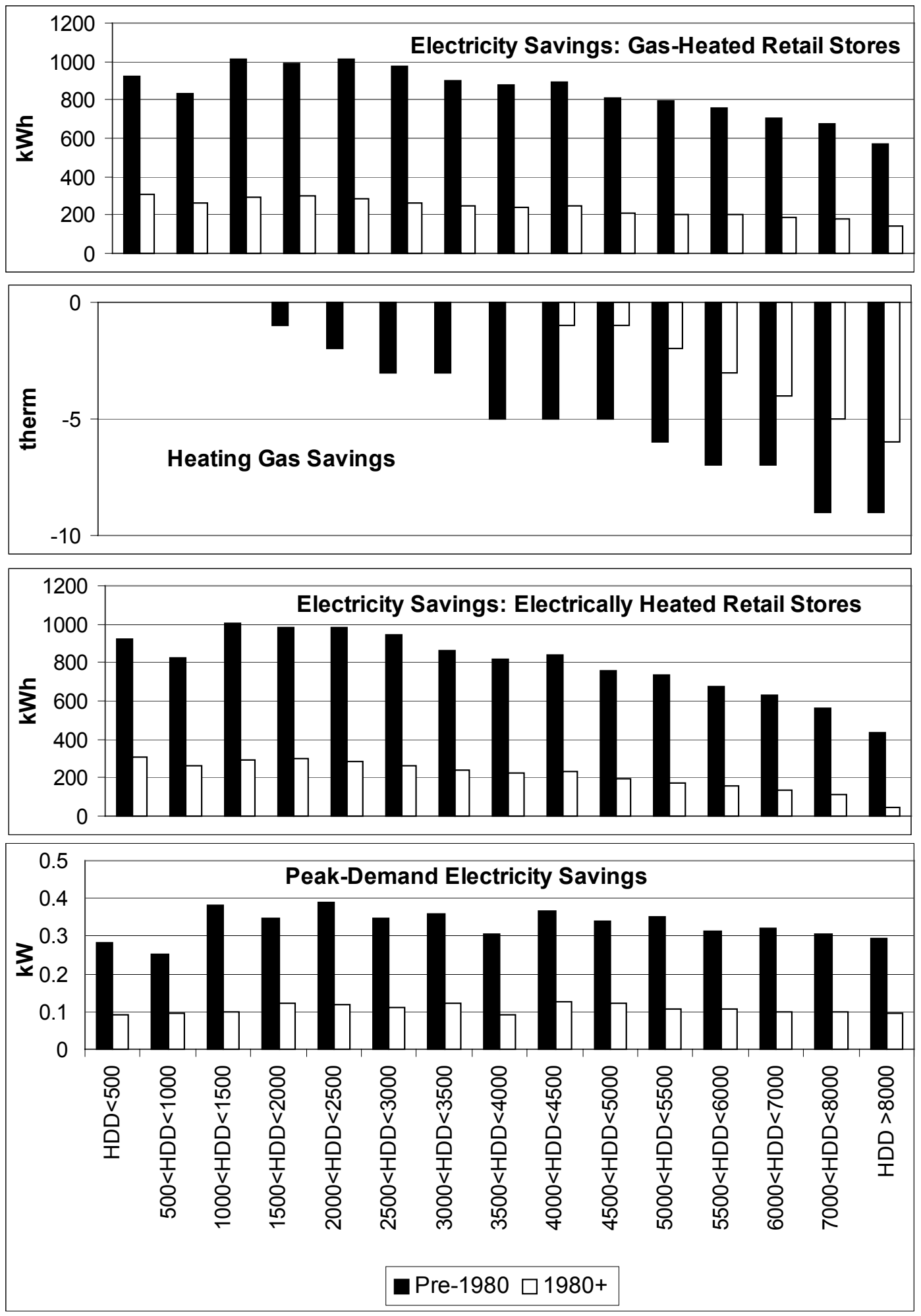

Figure 5a(ii). Retail Store Buildings. Effect of Cool Roofs, as a function of heating-degreedays: Annual cooling-electricity savings and heating-gas savings for gas-heated houses, combined heating- and cooling-electricity savings for electrically heated houses, and peakelectricity demand savings. All estimates are normalized per $1000 \mathrm{ft}^{2}$ of roof area. 

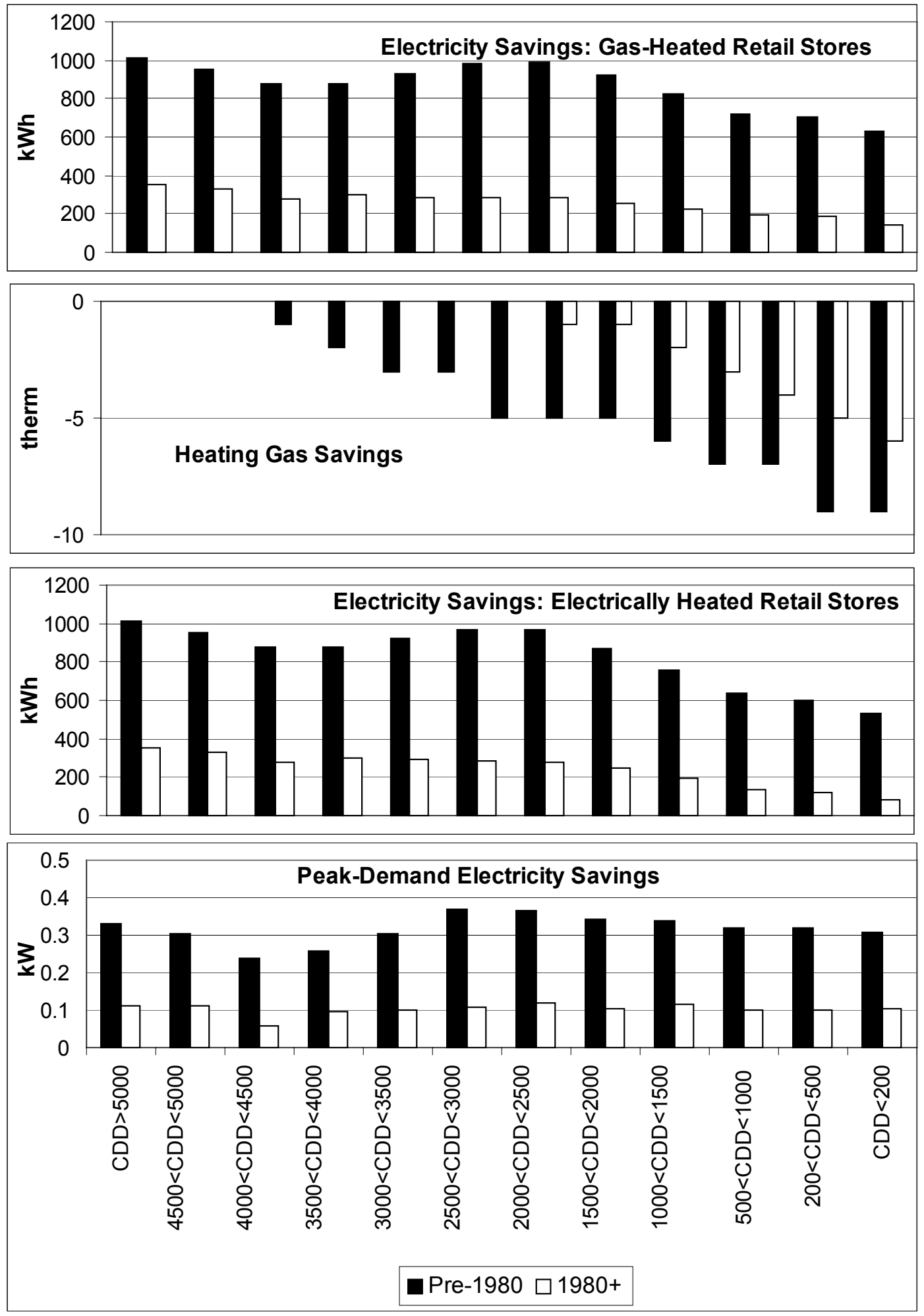

Figure 5b(ii). Retail Store Buildings. Savings from Cool Roofs as a function of coolingdegree-days: Annual cooling-electricity savings and heating-gas savings for gas-heated houses, combined heating- and cooling-electricity savings for electrically heated houses, and peakelectricity demand savings. All estimates are normalized per $1000 \mathrm{ft}^{2}$ of roof area. 



Figure 5a(iii). Retail Store Buildings. Savings from Shade Trees as a function of heatingdegree-days: Annual cooling-electricity savings and heating-gas savings for gas-heated houses, combined heating- and cooling-electricity savings for electrically heated houses, and peakelectricity demand savings. All estimates are normalized per $1000 \mathrm{ft}^{2}$ of roof area. 

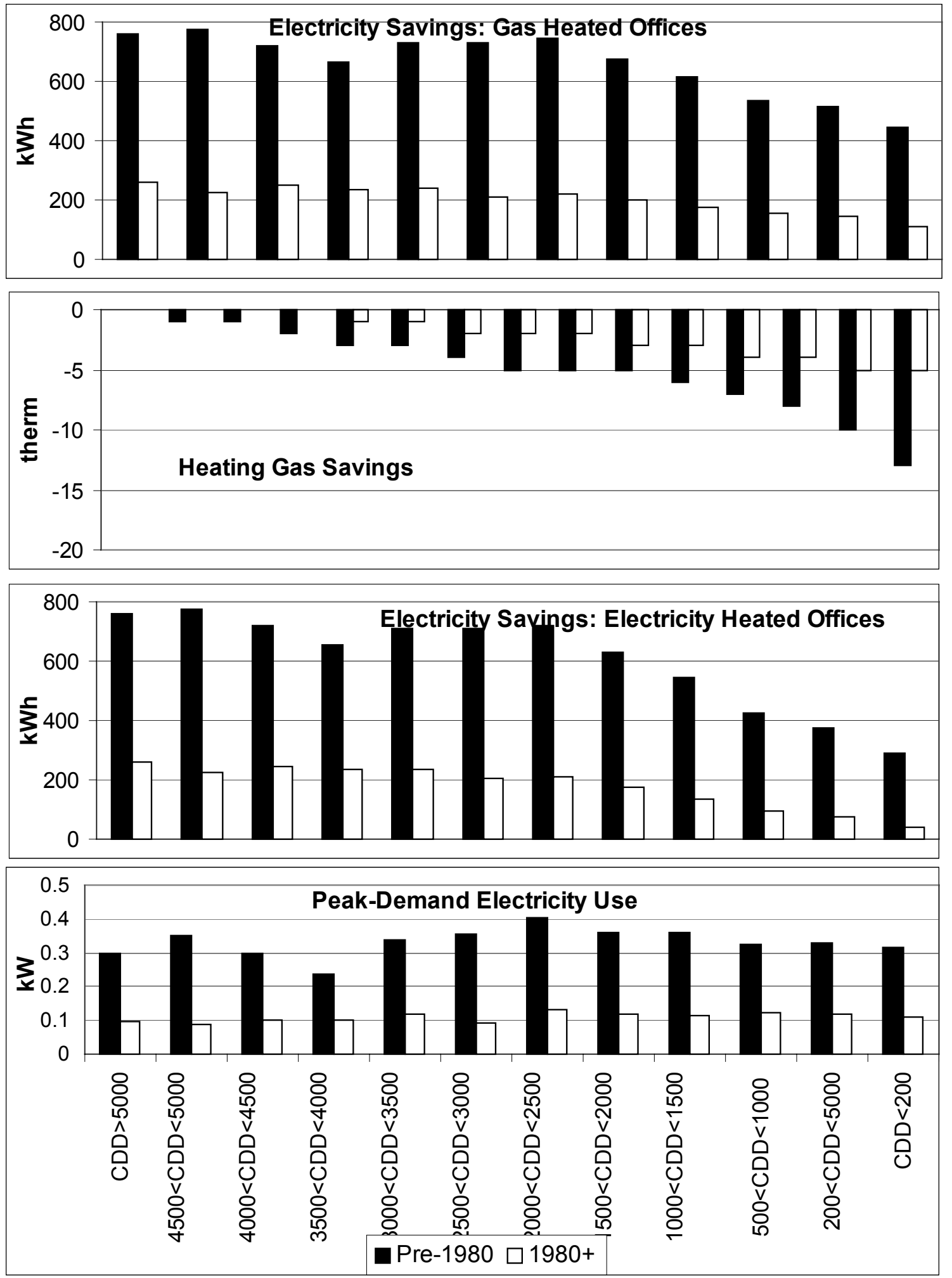

Figure 5b(iii). Retail Store Buildings. Savings from Shade Trees as a function of coolingdegree-days: Annual cooling-electricity savings and heating-gas savings for gas-heated houses, combined heating- and cooling-electricity savings for electrically heated houses, and peakelectricity demand savings. All estimates are normalized per $1000 \mathrm{ft}^{2}$ of roof area. 

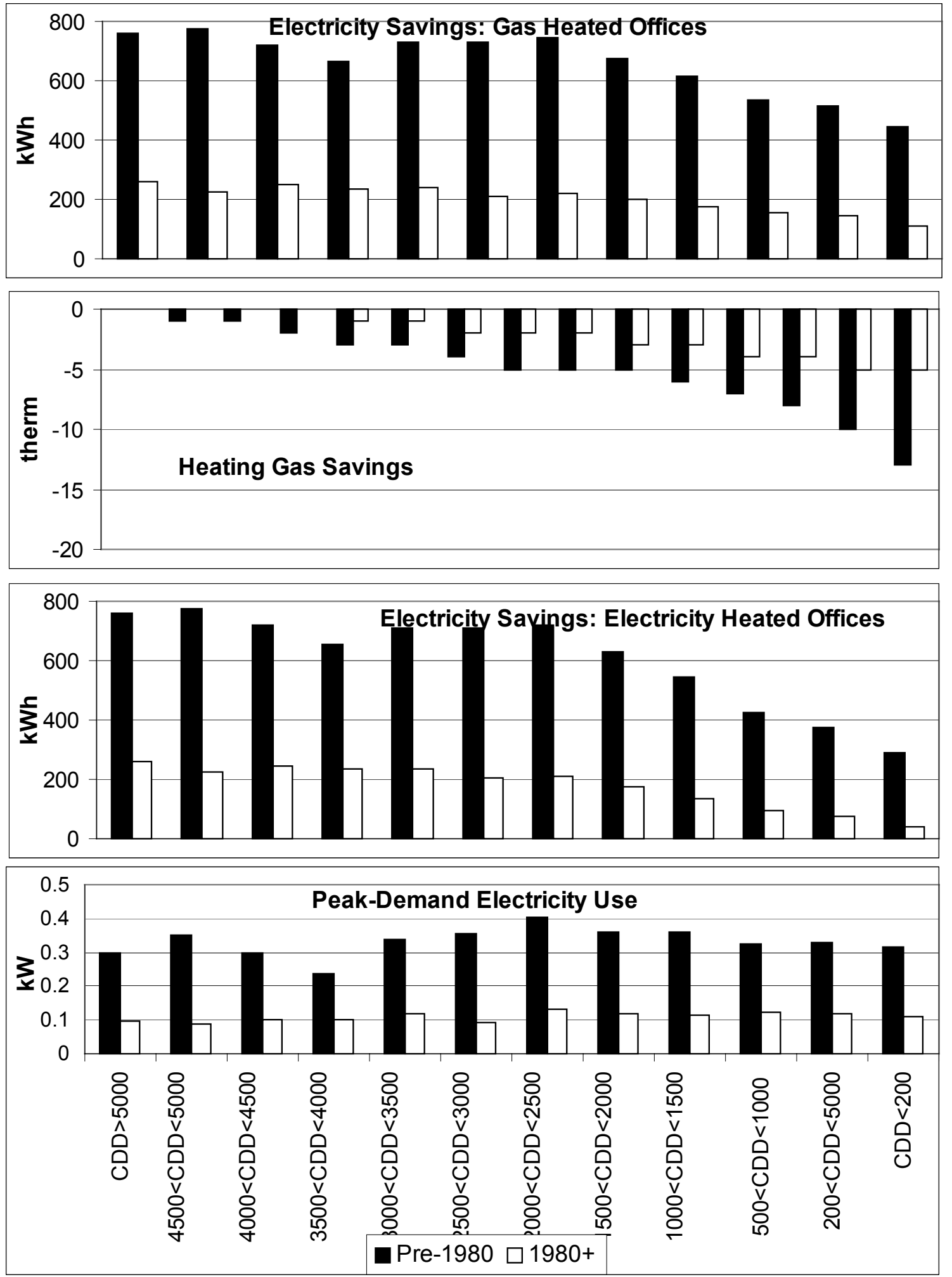

Figure 5a(iv). Retail Store Buildings. Indirect Savings as a function of heating-degree-days: Annual cooling-electricity savings and heating-gas savings for gas-heated houses, combined heating- and cooling-electricity savings for electrically heated houses, and peak-electricity demand savings. All estimates are normalized per $1000 \mathrm{ft}^{2}$ of roof area. 

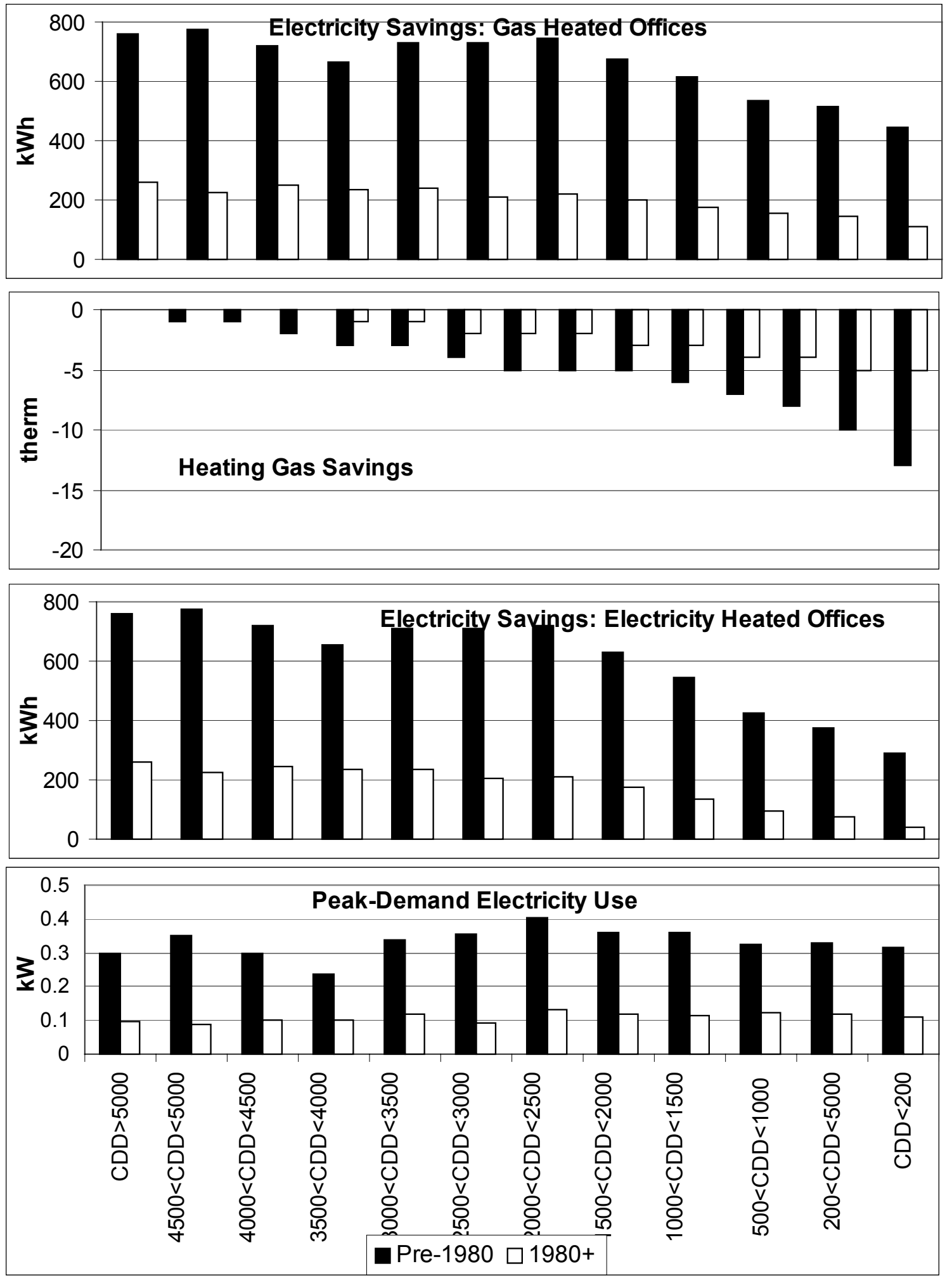

Figure 5b(iv). Retail Store Buildings. Indirect Savings as a function of cooling-degree-days: Annual cooling-electricity savings and heating-gas savings for gas-heated houses, combined heating- and cooling-electricity savings for electrically heated houses, and peak-electricity demand savings. All estimates are normalized per $1000 \mathrm{ft}^{2}$ of roof area. 

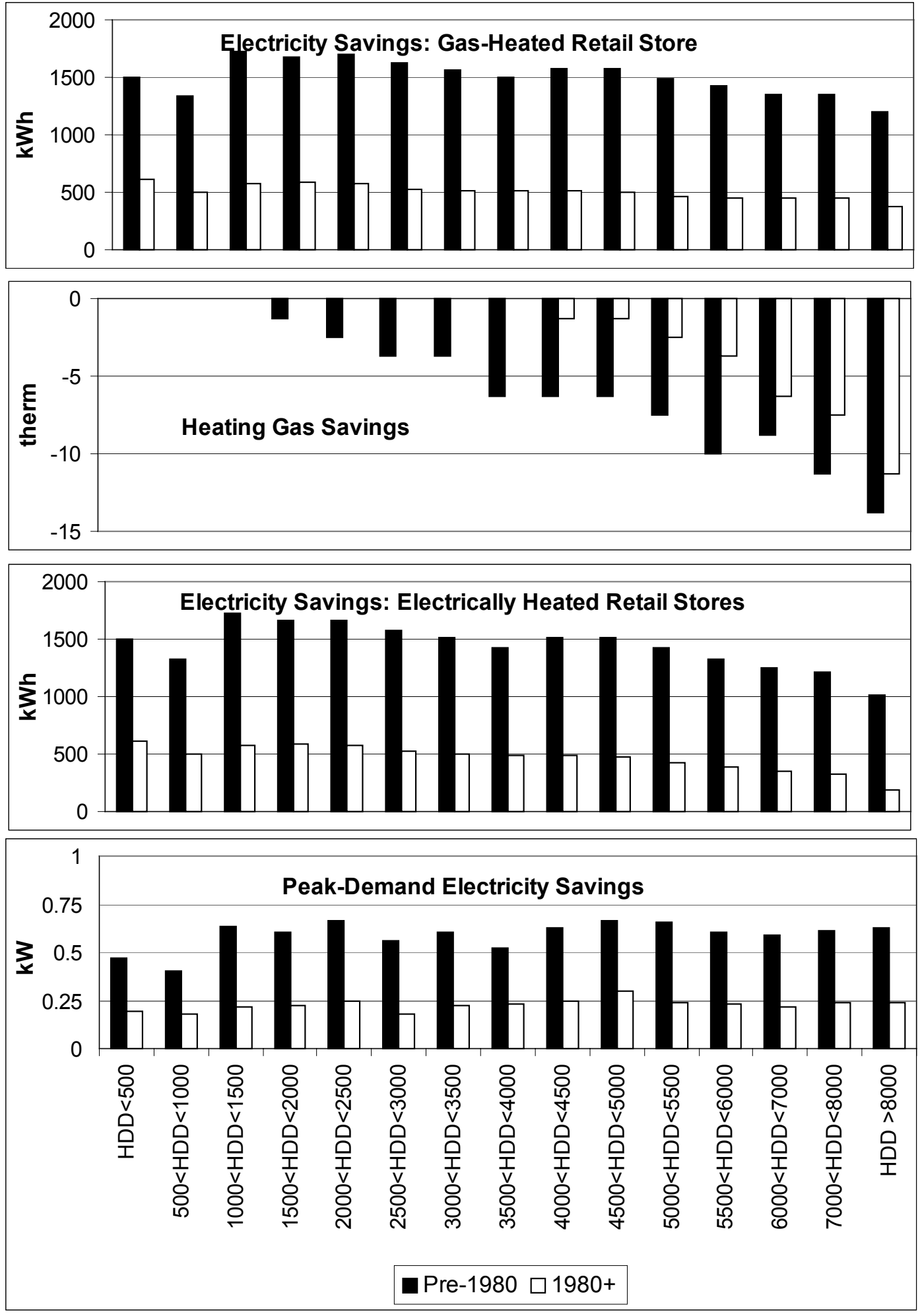

Figure 5a(v). Retail Store Buildings. Combined Direct and Indirect Savings as a function of heating-degree-days: Annual cooling-electricity savings and heating-gas savings for gas-heated houses, combined heating- and cooling-electricity savings for electrically heated houses, and peak-electricity demand savings. All estimates are normalized per $1000 \mathrm{ft}^{2}$ of roof area. 

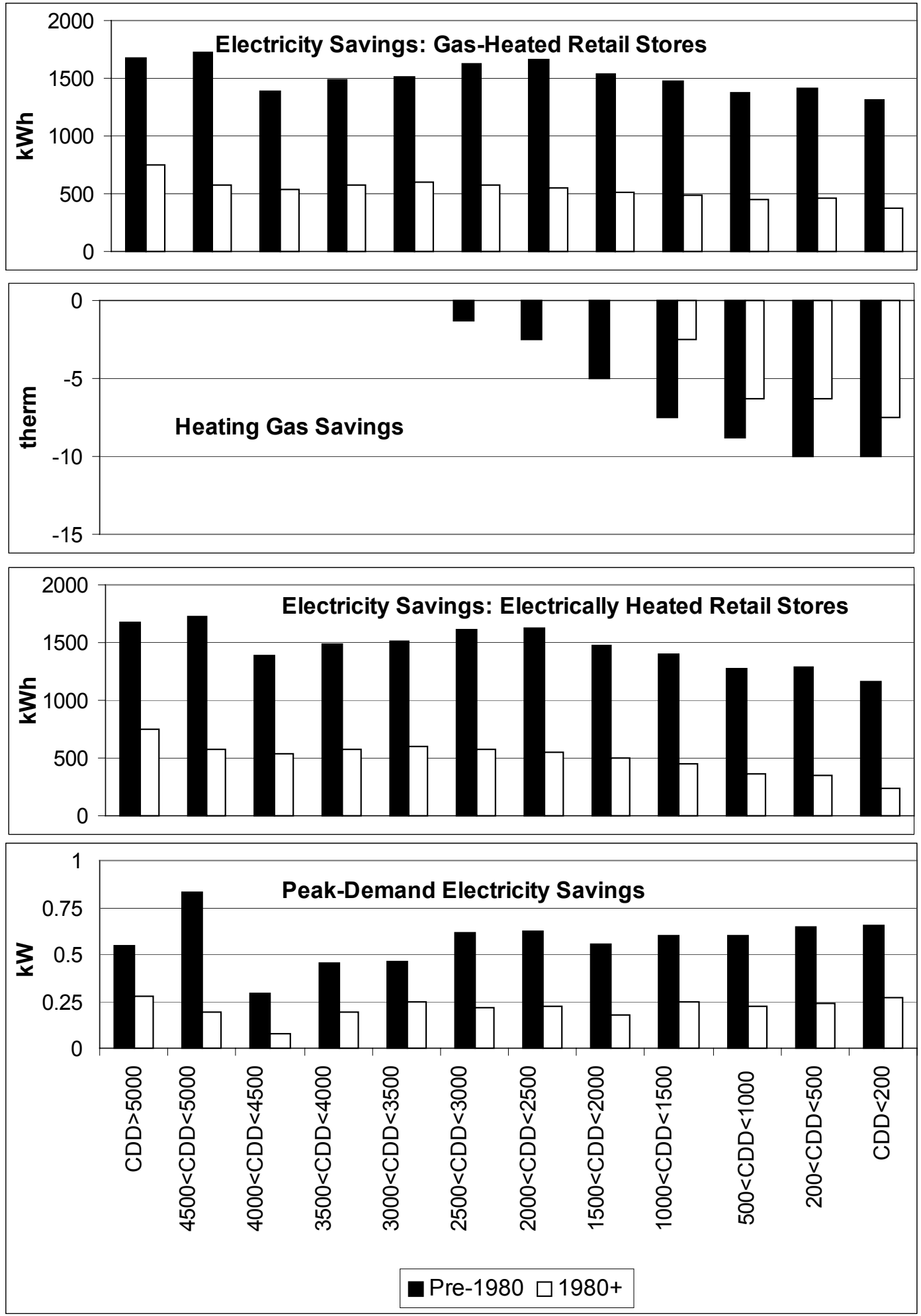

Figure 5b(v). Retail Store Buildings. Combined Direct and Indirect Savings as a function of cooling-degree-days: Annual cooling-electricity savings and heating-gas savings for gas-heated houses, combined heating- and cooling-electricity savings for electrically heated houses, and peak-electricity demand savings. All estimates are normalized per $1000 \mathrm{ft}^{2}$ of roof area. 